UNIVERSIDADE DE BRASÍLIA

INSTITUTO DE BIOLOGIA

DEPARTAMENTO DE BIOLOGIA CELULAR

Uso de baculovírus como ferrramenta para produção de antígenos vacinais e "virus like particles" (VLPs)

\title{
Capítulo I:
}

Expressão de proteínas do vírus da febre amarela fusionadas à proteína do envelope de baculovírus

Capitulo II:

Produção de VLPs de HIV-1 utilizando células de inseto "GP64 free"

Lorena Carvalho de Souza Chaves

Brasília

2016 
UNIVERSIDADE DE BRASÍLIA

INSTITUTO DE BIOLOGIA

DEPARTAMENTO DE BIOLOGIA CELULAR

Uso de baculovírus como ferrramenta para produção de antígenos vacinais e "virus like particles" (VLPs)

\section{Capítulo I:}

Expressão de proteínas do vírus da febre amarela fusionadas à proteína do envelope de baculovírus

Capítulo II

Produção de VLPs de HIV-1 utilizando células de inseto "GP64 free"

Lorena Carvalho de Souza Chaves

Tese de Doutorado apresentada ao Programa de Pós-Graduação em Biologia Molecular da Universidade de Brasília, como parte dos requisitos necessários à obtenção do título de Doutor em Biologia Molecular

Orientador: Dr. Bergmann Morais Ribeiro

Co-orientador no exterior: Dr. Gary W. Blissard 
Tese de autoria de Lorena Carvalho de Souza Chaves, intitulada "Uso de baculovírus como ferrramenta para produção de antígenos vacinais e "virus like particles" (VLPs)", apresentada como parte dos requisitos para a obtenção do título de Doutor em Biologia Molecular da Universidade de Brasília - UnB, em 15 de junho de 2016, aprovada pela banca examinadora abaixo:

Dr. Bergmann Morais Ribeiro

Universidade de Brasília - UnB - Orientador

Dra. Soraia Attie Calil Jorge

Instituto Butantan - SP

Dr. Tatsuya Nagata

Universidade de Brasília - UnB

Dra. Maria Elita Batista de Castro

EMBRAPA - CENARGEN

Dr. Marcelo de Macedo Brígido

Universidade de Brasília - UnB

Suplente: Dr. Enrique Roberto Argañaraz

Universidade de Brasília - UnB 
Dedicatória

Para minha mãe Graça e irmã Larissa.

Para meu marido, amigo e companheiro Marcus.

Vocês são o sentido de tudo. 


\section{Agradecimentos}

Inicialmente eu não poderia deixar de agradecer a Deus por essa oportunidade incrível que é viver. Sob sua luz continuo trilhando meu caminho, algumas vezes com derrotas, mas as vitórias (como essa) me lembram da sua profunda compaixão. Obrigada! Agradeço a minha mãe Graça, essa vitória também é sua, te amo profundamente! Agradeço também a minha irmã Larissa, obrigada por me ensinar a seguir em frente apesar das dificuldades da vida, te amo!

Enfim, meu amor Marcus. Não existem palavras para expressar minha eterna gratidão. Você foi minha fortaleza, minha companhia e minha força de vontade. Dividimos muito mais que um teto, dividimos história de vida e muita cumplicidade. Amo-te!!!

Aos meus queridos sobrinhos Thaís, Clara, Davi, Liz e Isadora, que despertam o melhor em mim e me dão força para continuar.

Ao professor Bergmann, que eu tive a sorte e o privilégio de ser aluna. Obrigada por acreditar em mim e manter todas as portas abertas. Minha gratidão profunda ao Sr.

Ao professor e meu orientador no período sanduíche Dr. Gary Blissard. Com ele aprendi bondade, profissionalismo e amor a ciência. O Gary é um cientista inspirador. Essa experiência em seu laboratório mudou tudo. Obrigada!

Agradeço ao professor Tatsuya e Renato por sempre serem solícitos quando requisitados. À professora Anamélia Bocca, por sua colaboração e sugestões. Meu obrigada também aos seus alunos Márcio e Isaque.

À Dra. Maria Elita por ter iniciado minha paixão por ciência. Aproveitando, agradeço a todas as pessoas da época de Embrapa (Iniciação científica) que foram sempre tão amáveis comigo: Marlinda, Zildinha, William querido, Raimundinha, Briana, Juliana e Saluana (amigas lindas).

Agradeço a todo mundo, sem exceções, do laboratório de Baculovírus da UnB. Local onde fiz o meu mestrado e agora doutorado. Todos esses anos foram fundamentais para o meu crescimento emocional, profissional e pessoal. Porém, algumas pessoas tornaram meus dias mais alegres dentro do laboratório, principalmente no último ano do meu doutorado, são elas: Mariana Senna, Mayarha, Deborah e Laís. Obrigada por acreditarem em mim e serem amigas maravilhosas. 
Às amigas que conheci neste mesmo laboratório e agora são profissionais de sucesso: Anabele e Carol. Obrigada!

Aos amigos dos laboratórios de Virologia (Holanda e Japão). Que muitas vezes me ouviram e ajudaram nos trabalhos. Desejo sucesso galera!

Aos amigos do laboratório de Microscopia eletrônica agradeço a ajuda, carinho e torcida. Aos amigos Jeff, Rita e Lisa do laboratório Blissard, que me ajudaram em tudo e fizeram com que eu me sentisse em casa, mesmo estando em outro país.

Galerinha do Maple Hill, obrigada por serem minha família americana. Aqui cito: Marislaine (Maris amiga querida), Larissa, Carlos (José), Camila, Vivi e Milena. Nossas histórias estão guardadas no coração. Agradeço a todos os amigos de Ithaca, obrigada por todos os momentos. Para Patrícia e Rogério um agradecimento especial.

Aos meus amigos de uma vida inteira (Trupe). Alguns conheço muito antes de pensar em seguir essa carreira. Desculpem as ausências, estresses e dificuldades. Vocês fazem parte de tudo isso aqui. Amo vcs!

Por fim e não menos importante, minhas famílias: Carvalho, Souza, Passarinho e Chaves. Obrigada por me acolherem sempre.

Agradeço a Capes e a UnB pelo apoio financeiro durante todo o doutorado e por patrocinarem a experiência mais incrível da minha vida: o doutorado sanduíche.

À todos que torceram e acreditaram nessa vitória. Eu consegui! Obrigada! 
"Gostaria que você soubesse que existe dentro de si uma força capaz de mudar sua vida, basta que lute e aguarde um novo amanhecer".

Margaret Thatcher 


\section{Resumo}

Os baculovírus são vírus de insetos amplamente utilizados no controle biológico de pragas agrícolas e também como ferramenta para expressão de proteínas heterólogas. Os baixos custos, a segurança na manipulação e as diferentes formas de expressão de proteínas tornam os baculovírus e células de inseto uma escolha eficaz para a correta expressão de antígenos vacinais e produção de VLPs ("Virus like particles"). No capítulo 1 deste trabalho, foi avaliado o potencial imunogênico de BVs ("Budded virus") recombinantes contendo o EDIII (Domínio III da proteína de envelope do vírus da Febre amarela - FA) fusionado à proteína GP64 dos baculovírus Autographa californica multiple nucleopolyhedrovirus (AcMNPV) e Anticarsia gemmatalis multiple nucleopolyhedrovirus (AgMNPV); e também de uma massa protéica gerada pela fusão de EDIII com a proteína poliedrina de AcMNPV. O EDIII interage com os receptores celulares e contém os epítopos reconhecidos pelos anticorpos neutralizantes, sendo assim alvo para a produção de uma vacina de subunidade. Foi mostrado neste trabalho, a confirmação da correta expressão das proteínas recombinantes (GP64 + EDIII e Poliedrina + EDIII) por Western blot, microscopia de luz e confocal. No caso do EDIII fusionado à GP64 de AcMNPV e AgMNPV, as partículas virais recombinantes foram purificadas e inoculadas em camundongos. O teste de proliferação de linfócitos indicou uma maior proliferação em camundongos inoculados com o vírus recombinante contendo o EDIII fusionado à proteína GP64 do baculovírus AgMNPV quando comparado com o controle LPS. Testes complementares serão feitos, para avaliar o perfil da resposta imunológica e confirmar a obtenção de um antígeno vacinal contra FA. No capítulo 2, o sistema baculovírus de expressão foi utilizado para expressar o precursor da proteína GAG (Pr55) de HIV-1. A expressão de Pr55 HIV-1 é suficiente para a montagem de VLPs na membrana plasmática da célula do hospedeiro. Porém, a proteína GP64 de baculovírus é altamente imunogênica e também é expressa na superfície de células infectadas e normalmente está presente na superfície da VLP. Neste trabalho, mostramos que não é possível separar BVs e VLPs produzidos em um mesmo ciclo de infecção por baculovírus mesmo usando diferentes metodologias de separação. Então, utilizando um sistema que consegue produzir baculovírus recombinantes livres de GP64, foi construído o vírus recombinante vGAGHIV-1 GP64 null e utilizado na infecção de células Sf9. Por Western blot foi observado a perda do sinal da proteína GP64 de baculovírus no extrato de células infectadas com esse vírus recombinante. Essas mesmas células foram visualizadas por microscopia eletrônica de transmissão (MET), mostrando que mesmo quando GP64 não está presente (o que resulta na ausência de produção de BVs), o brotamento de VLPs continua a acontecer. Essa técnica mostrou-se eficiente para a produção de VLPs livres de partículas ou proteínas baculovirais. Este trabalho confirma a eficiência do uso do sistema de expressão baseado em baculovírus para a expressão de proteínas e VLPs de interesse famacológico.

Palavras - chave: Baculovírus; EDIII; Febre amarela; Poliedrina; VLP; HIV-1; GP64. 


\begin{abstract}
Baculoviruses are insect viruses widely used in the biological control of agricultural pests and as a tool for heterologous protein expression. Their low production costs, security in manipulation and the many ways of protein expression, make baculoviruses and insect cells an effective choice for the efficient expression of vaccine antigens and VLPs (Virus like particles) production. In chapter 1 of this work, it was evaluated the immunogenic potential of recombinant BVs (Budded virus) containing EDIII (Yellow fever virus -YFenvelope protein domain III) fused to the Autographa californica multiple nucleopolyhedrovirus (AcMNPV) and Anticarsia gemmatalis multiple nucleopolyhedrovirus (AgMNPV) GP64 protein; and also of a protein mass generated by the fusion of the EDIII and AcMNPV polyhedrin protein. The EDIII interacts with cell receptors and contains epitopes recognized by neutralizing antibodies, being the target for the production of a subunit vaccine. We showed in this work the confirmation of the correct recombinant protein expression (GP64 + EDIII and Polyhedrin + EDIII) by Western blot, optical and confocal microscopy. In the case of the EDIII fused with AcMNPV and AgMNPV GP64, the recombinant viral particles were purified and inoculated in mice. The lymphocyte proliferation assay showed a higher proliferation in mice immunized with recombinant virus containing the EDIII fused with the GP64 from the AgMNPV baculovirus comparing to the LPS control. Complementary assays will be carried out in order to evaluate the immunological response pattern and to confirm the production of a vaccine antigen against YF. In chapter 2, the baculovirus expression system was used to express the GAG protein precursor (Pr55) of HIV-1. The Pr55 expression is sufficient to VLP assembly on the cell host plasma membrane. However, the GP64 baculovirus protein is highly immunogenic and is also expressed on the surface of infected cells and is also present on the surface of the VLP. In this work, we showed that is not possible to separate BVs and VLPs produced in the same baculovirus infection cycle using different separation methodologies. Then, using a system able to produce GP64 free recombinant baculovirus, the recombinant virus vGAGHIV-1 GP64 null was produced and used to infect Sf9 cells. By Western blot analyses, it was shown that the baculovirus protein GP64 signal was missing in the recombinant virus infected cell extract. These same cells were observed by transmission electron microscopy (MET), showing that even when the GP64 is absent (which results in the absence of BVs production), VLPs budding continues to happen. This technique was shown to be efficient for VLPs production, free of baculvirus particles or proteins. This work confirms the efficiency of the baculovirus expression system for protein expression and VLPs of pharmacological interest.
\end{abstract}

Key - words: Baculovirus; EDIII; Yellow fever; Polyhedrin; VLP; HIV-1; GP64. 


\section{Índice de figuras}

Figura 1. Árvore filogenética representativa dos quatro gêneros da família

Baculoviridae 16

Figura 2. Ciclo de infecção do baculovírus. ............................................................ 18

Figura 3. Ciclos epidemiológicos (silvestre e urbano) da febre amarela. 23

Figura 4. Estrutura genômica do vírus da febre amarela com genes estruturais, não estruturais, regiões não codantes 5' NCR e 3' NCR e a formação das proteínas virais após o processamento proteolítico

Figura 5. Processamento da poliproteína de flavivirus.

Figura 6. Esquema representativo de um dímero de proteína E do vírus da febre amarela

Figura 7. Representação esquemática da partícula de flavivirus e ciclo de infecção viral

Figura 8. Epítopos neutralizantes no domínio III (EDIII) da proteína de envelope do vírus da febre amarela.

Figura 9. Esquema representativo dos cassetes de expressão para fusão com a proteína GP64 de baculovírus 41

Figura 10. Esquema representativo do plasmídeo pGEM ${ }^{\circledR}$-T Easy - Promega.. ......... 43

Figura 11. Esquema representativo do plasmídeo pFASTBAC ACCI.. ....................... 44

Figura 12. Esquema representativo dos cassetes de expressão do EDIII fusionado à proteína GP64 de baculovírus. 46

Figura 13. Esquema representativo do plasmídeo pFASTBACI-6xHis-AcPH.

Figura 14. Sistema de imunização de camundongos com os baculovírus recombinantes.

Figura 15. Mapa dos plasmídeos pFASTBAC ACCI GP64 Ac e pFASTBAC ACCI GP64 Ag

Figura 16. Mapa dos plasmídeos pFASTBAC ACCI GP64 EDIII Ac e pFASTBAC ACCI GP64 EDIII Ag 
Figura 17. Confirmação da clonagem dos plasmídeos pFASTBAC ACCI GP64 Ac, pFASTBAC ACCI GP64 Ag, pFASTBAC ACCI GP64 EDIII Ac e pFASTBAC ACCI GP64 EDIII Ag por digestão com as enzimas de restrição Sph I e Sac I. 61

Figura 18. Mapa do plasmídeo pFASTBACI-6xHis-AcPH EDIII.. 62

Figura 19. Confirmação da clonagem do plasmídeo pFASTBACI-6xHis-AcPH EDIII por digestão com as enzimas de restrição BamH I e Nco I. 63

Figura 20. Efeito citopático da infecção de células BTI-Tn5B1-4 com diferentes baculovírus a $72 \mathrm{~h} \mathrm{p.i.}$

Figura 21. Análise do perfil da proteína recombinante EDIII fusionada à poliedrina de AcMNPV 65

Figura 22. Análise do perfil da proteína recombinante EDIII fusionada à GP64. 67

Figura 23. Análise do perfil da proteína recombinante EDIII fusionada à GP64 na superfície de células de inseto 68

Figura 24. Análise da proliferação de linfócitos testados com diferentes estímulos..... 71

Figura 25. Esquema ilustrativo do genoma do vírus HIV ...................................... 82

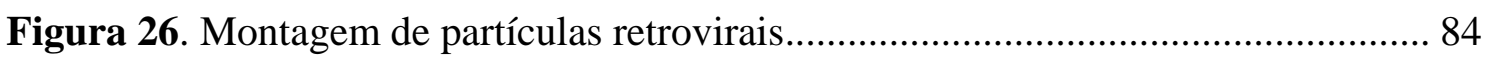

Figura 27. Principais fases da formação de VLPs envelopados e não envelopados em células de inseto. 87

Figura 28. Esquema representativo do plasmídeo 125-pFB-HIV-2gb . 92

Figura 29. Foto dos gradientes de sacarose utilizados para purificar BVs e VLPs 98

Figura 30. Análise da separação de BVs a partir de sobrenadante de células Sf9 infectadas com AcMNPV

Figura 31. Análise da separação de BVs e VLPs a partir de sobrenadante de células Sf9 infectadas com vGAGHIV-1 100

Figura 32. Ensaio de fusão da célula Sf9 $9^{\text {Op1D }}$ 102

Figura 33. Western blot de extrato de células não-infectadas (Mock-1) e infectadas com AcMNPV (2), vGAGHIV-1 (3) e vGAGHIV-1 GP64 null (4).................................. 103

Figura 34. Análise por MET de VLPs de HIV-1 produzidas em células de inseto..... 105 


\section{Índice de tabelas}

Tabela 1. Oligonucleotídeos utilizados no trabalho 


\section{Abreviaturas e símbolos}

\begin{tabular}{|c|c|}
\hline $6 \mathrm{xHis}$ & cauda de hexa-histidina \\
\hline$g$ & velocidade de sedimentação gravitacional \\
\hline AcMNPV & Autographa californica multicapsid nucleopolyhedrovirus \\
\hline AgMNPV & Anticarsia gemmatalis multiple nucleopolyhedrovirus \\
\hline BCIP & 5-bromo-4-chloro-3-indolyl phosphate \\
\hline BSA & albumina sérica bovina \\
\hline $\mathrm{BV}$ & "Budded virus" \\
\hline cDNA & DNA complementar \\
\hline DENV & vírus da dengue \\
\hline dNTP & deoxinucleotídeos \\
\hline DNA & ácido desoxirribonucleico trisfosfato \\
\hline EDTA & ácido etilenodiaminotetracético \\
\hline EDIII & domínio III da proteína de envelope \\
\hline FA & febre amarela \\
\hline FITC & "fluorescein isothiocyanate" \\
\hline $\mathrm{g}$ & grama \\
\hline $\mathrm{h}$ & hora \\
\hline h p.i. & horas após infecção \\
\hline $\mathrm{HCl}$ & ácido clorídrico \\
\hline HIV & "Human Immunodeficiency Virus" \\
\hline IPTG & isopropil $\beta$-D-1-tiogalactopiranosídeo \\
\hline $\mathrm{kDa}$ & quilodaltons \\
\hline
\end{tabular}




\begin{tabular}{|c|c|}
\hline M & molar: mol/L \\
\hline MW & peso molecular \\
\hline $\mathrm{mg}$ & miligrama $=10^{-6}$ grama \\
\hline $\min$ & minuto \\
\hline $\mathrm{ml}$ & mililitro \\
\hline $\mathrm{mm}$ & milímetro \\
\hline $\mathrm{mM}$ & milimolar \\
\hline m.o.i & "Multiplicity of infection" \\
\hline $\mathrm{NaCl}$ & cloreto de sódio \\
\hline $\mathrm{NaOH}$ & hidróxido de sódio \\
\hline NBT & Nitro blue tetrazolium chloride \\
\hline ODV & "Occluded-derived virus" \\
\hline ng & nano grama \\
\hline $\mathrm{pb}$ & pares de base \\
\hline PBS & tampão fosfato salino \\
\hline PCR & reação em cadeia da polimerase \\
\hline $\mathrm{pH}$ & potencial de hidrogênio \\
\hline PTA & ácido fosfotúngstico \\
\hline RNA & ácido ribonucléico \\
\hline $\mathrm{rpm}$ & rotação por minuto \\
\hline RPMI & "Roswell Park Memorial Institute medium" \\
\hline $\mathrm{S}$ & segundo \\
\hline SDS & dodecilsulfato de sódio \\
\hline
\end{tabular}


Tris tris (hidroximetil) aminometano

U unidade enzimática

VLP "Virus like particle"

X-Gal 5-bromo-4-cloro-3-indolil-D-galactopiranosídeo

YFV "Yellow fever virus" - vírus da febre amarela

$\mu \mathrm{g} \quad$ micrograma

$\mu \mathrm{l} \quad$ microlitro

$\mu \mathrm{M} \quad$ micromolar (micromol por litro)

$\mu \mathrm{m} \quad$ micrometro

${ }^{\circ} \mathrm{C} \quad$ grau Celsius 


\section{Índice}

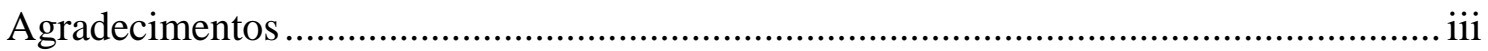

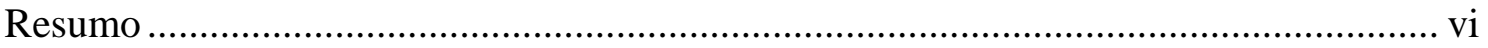

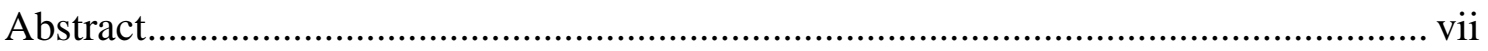

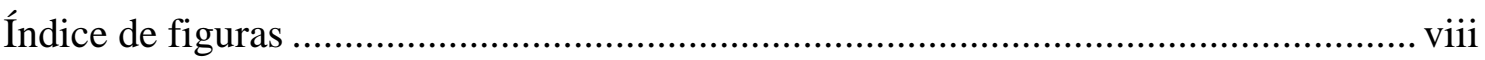

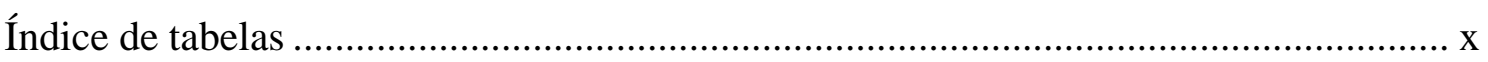

Abreviaturas e símbolos ...................................................................................... .

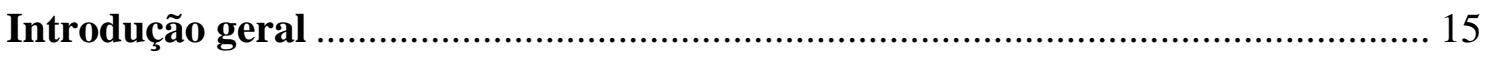

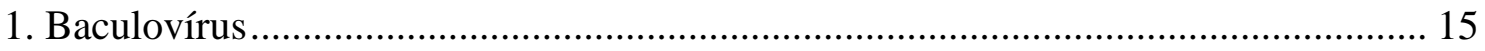

1.2. Taxonomia e ciclo de infecção ………………………………………………... 16

1.3. Baculovírus como vetor de expressão............................................................ 18

Capítulo I - Expressão de proteínas do vírus da febre amarela fusionadas à proteína do

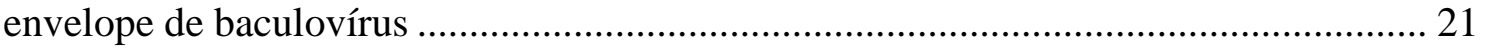

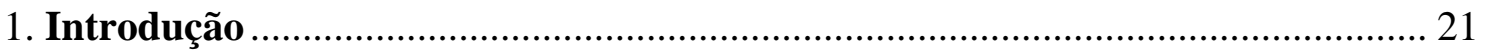

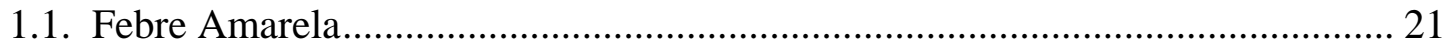

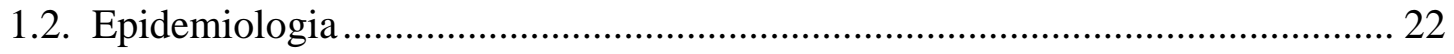

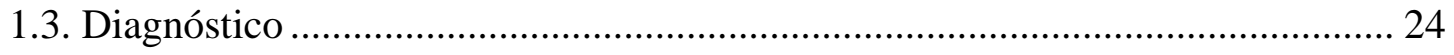

1.4. Tratamento e Prevenção.................................................................................. 25

1.5. Vírus da febre amarela - Estrutura, processamento e função das proteínas........ 26 
1.6. Vírus da febre amarela - Replicação e montagem de novas partículas virais 32

1.7. Proteína E e NS1 como proteínas imunogênicas 35

1.8. "Display" do EDIII de FA na superfície de baculovírus 36

2. Objetivo 39

2.1. Objetivos específicos 39

3. Material e métodos 40

3.1. Vírus e células 40

3.2. Construção dos vetores para expressão das proteínas recombinantes na superfície de baculovírus 40

3.3. Construção dos plasmídeos para expressão do domínio III da proteína de envelope do vírus da febre amarela na superfície da partícula BV de baculovírus ... 46

3.4. Construção do vetor de transferência contendo o cassete gênico EDIII fusionado ao gene da poliedrina 48

3.5. Construção dos vírus recombinantes contendo os fragmentos gênicos de interesse, fusionados aos genes da proteína do envelope (GP64) ou à proteína do corpo de oclusão (poliedrina) de baculovírus

3.6. Análise da expressão das proteínas recombinantes

3.6.1. SDS-PAGE e Western-blot

3.6.2. Microscopia confocal

3.7. Imunização dos camundongos

3.8. Teste de proliferação de linfócitos 58 
4.1. Confirmação da obtenção dos plasmídeos pFASTBAC ACCI GP64 Ac, pFASTBAC ACCI GP64 Ag, pFASTBAC ACCI GP64 EDIII Ac e pFASTBAC ACCI GP64 EDIII Ag.

4.3. Construção dos baculovírus recombinantes e confirmação da expressão das proteínas

4.3.1. EDIII fusionado a poliedrina de AcMNPV.

4.3.2. EDIII fusionado à GP64 de AcMNPV e AgMNPV.

5. Discussão

6. Perspectivas

Capítulo II - Produção de VLPs de HIV-1 utilizando células de inseto "GP64 free” ... 79

1. Introdução

1.1. HIV - Vírus da imunodeficiência humana ("Human Immunodeficiency Virus") 79

1.2. Tratamento e prevenção. 80

1.3. HIV-Taxonomia, estrutura e ciclo de infecção 81

1.4. Baculovírus como vetor de expressão para produção de VLPs 86

2. Objetivo 90

2.1. Objetivos específicos 90 
3.2. Obtenção do plasmídeo que contém o gene gag de HIV e construção dos baculovírus recombinantes

3.3. Análise da produção de BVs de baculovírus e VLPs (GAG HIV-1) após purificação em gradiente de sacarose

3.4. Contrastação negativa e análise do perfil de brotamento VLPs e BVs por Microscopia Eletrônica de Transmissão (MET)

3.5. Imunomarcação de VLPs de HIV-1 e análise por MET 96

4. Resultados 97

4.1. Confirmação da expressão de GAG em células de inseto 97

4.2. Produção e caracterização de VLPs "GP64 free" 101

5. Discussão 106

7. Referências Bibliográficas 110

Anexos

Manuscrito do artigo científico 128

Termos de concessão de uso de imagens e certificado de aprovação do comitê de ética 


\section{Introdução geral}

\section{Baculovírus}

Os Baculovírus (família: Baculoviridae) são vírus de DNA que infetam insetos. Estes vírus são bem conhecidos por a sua utilidade e versatilidade como vetores de expressão gênica, pesticidas biológicos e vetores para a transdução em células de mamíferos (Clem \& Passarelli, 2013). Mais de 600 baculovírus já foram isolados de insetos da ordem Lepidoptera (borboletas e mariposas). Porém, alguns baculovírus também já foram isolados de insetos das ordens Hymenoptera (vespas, abelhas e formigas) e Diptera (moscas) (Herniou et al., 2012).

Os baculovírus são vírus de grande interesse industrial devido ao seu potencial no controle biológico de pragas agrícolas. No Brasil, os baculovírus AgMNPV (Anticarsia gemmatalis multiple nucleopolyhedrovirus), HaNPV (Helicoverpa armigera nucleopolyhedrovirus) e SfMNPV (Spodoptera frugiperda multiple nucleopolyhedrovirus) são utilizados comercialmente no combate de pragas da soja (no caso do AgMNPV), milho, tomate, algodão, tabaco (no caso do HaNPV), milho e sorgo (no caso do SfMNPV) (Haase et al., 2015).

O Baculovírus AgMNPV já foi amplamente utilizado no Brasil nos anos 2000/2003, sendo aplicado em mais de 2 milhões de hectares de plantação de soja no país. Porém, hoje o uso do AgMNPV como biopesticida diminuiu substancialmente, sendo utilizado em aproximadamente 200.000 hectares por ano (Haase et al., 2015; Moscardi \& Sosa-Gómez, 2000). 


\subsection{Taxonomia e ciclo de infecção}

A família Baculoviridae é composta por quatro gêneros: Alphabaculovirus (também conhecidos como Nucleopoliedrovírus de Lepidoptera), Betabaculovirus (Granulovírus de Lepidoptera), Gammabaculovirus (Nucleopoliedrovírus de Hymenoptera) e Deltabaculovirus (Nucleopoliedrovírus de Diptera) (Jehle et al., 2006) (Figura 1).

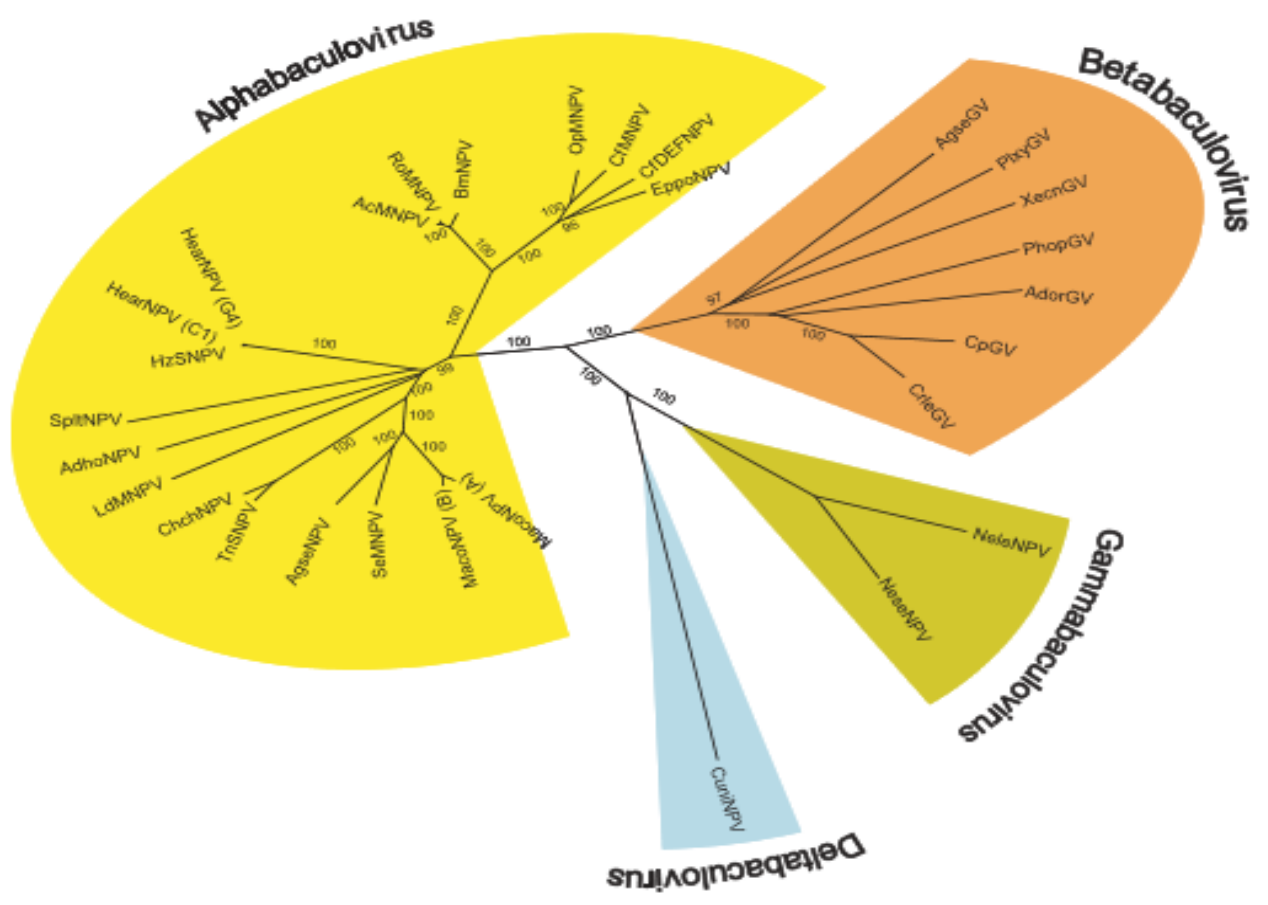

Figura 1. Árvore filogenética representativa dos quatro gêneros da família Baculoviridae. A árvore foi feita a partir do alinhamento das sequências protéicas de parte dos "core genes" (genes essenciais e presentes em todos os baculovírus) de 29 baculovírus sequenciados até 2006 (Jehle et al., 2006).

Existem dois tipos de vírions produzidos durante a infecção por baculovírus, os ODVs (vírus derivados de oclusão - "Occlusion-derived virus”) e os BVs (vírus brotados 
- "Budded virus"). Ambos contêm o mesmo genoma, mas diferem na morfogênese, composição dos envelopes e função dentro do ciclo de infecção viral. O ciclo de infecção de baculovírus na natureza é iniciado pelos vírus derivados de oclusão. Os ODVs são encontrados imersos em uma matriz protéica formando uma estrutura cristalina chamada corpo de oclusão ou $\mathrm{OB}$ (OB, do inglês: "Occlusion Body"), que oclui os vírions. A principal proteína que constitui os corpos de oclusão é a poliedrina ou granulina, dependendo do gênero do baculovírus. Os OBs são ingeridos por larvas de insetos e seguem pelo sistema digestivo (Rohrmann, 2013). Devido ao $\mathrm{pH}$ alcalino e as proteases presentes no intestino médio das lagartas, a matriz protéica é dissolvida liberando os ODVs que irão atravessar a membrana peritrófica e infectar as células epiteliais colunares por fusão das membranas dos vírions com as microvilosidades (Horton \& Burand, 1993). Após essa infecção primária, os BVs são formados e saem das células na direção da membrana basal, dando início a infecção sistêmica. Em períodos tardios da infecção viral, vírions são oclusos nos corpos de oclusão dentro do núcleo das células infectadas e são liberados no ambiente após a morte e desintegração do inseto (Rohrmann, 2013) (Figura 2).

Em células de inseto (in vitro) a infecção é iniciada por BVs, que entram nas células, via endocitose adsortiva. Diferentemente, os ODVs entram nas células por fusão direta de membranas (Horton \& Burand, 1993). A GP64, glicoproteína mediadora no processo de penetração do vírus na célula, promove a fusão da membrana endossomal com o envelope viral, liberando os nucleocapsídeos no citoplasma da célula hospedeira (Castro et al., 1999). 


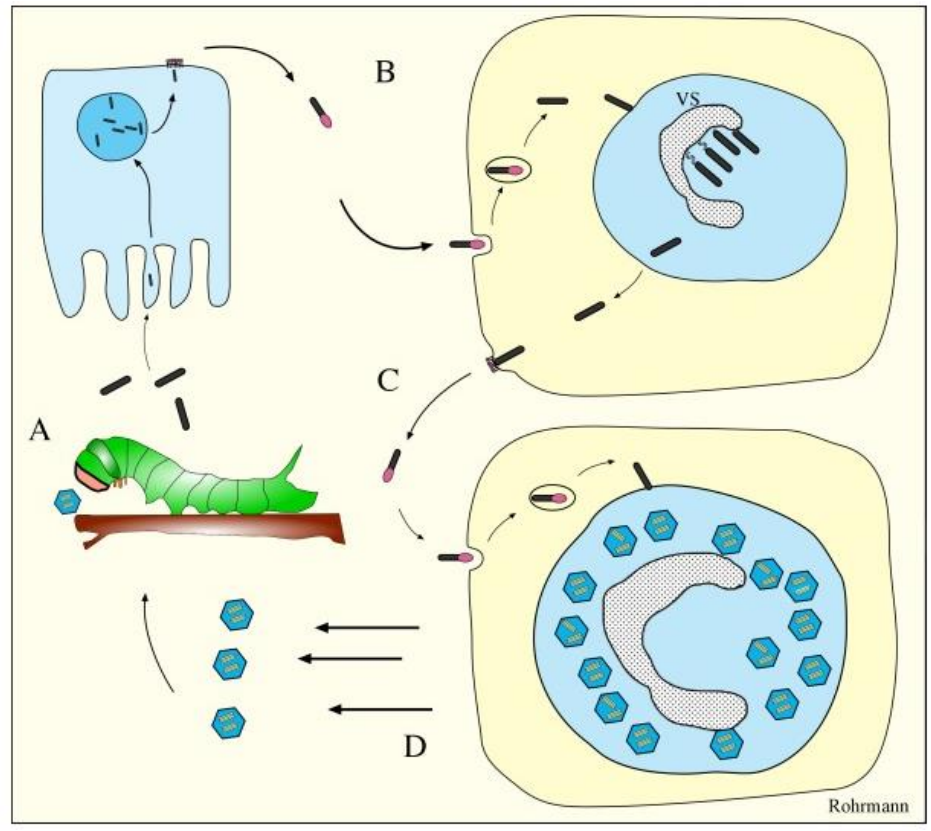

Figura 2. Ciclo de infecção do Baculovírus. (A) Corpos de oclusão presentes no meio ambiente são ingeridos pelo inseto e dissolvem-se no intestino médio devido ao $\mathrm{pH}$ alcalino, liberando os ODVs, que, em seguida, infectam as células epiteliais do intestino médio (B) Os BVs brotam para fora da célula iniciando o ciclo de infecção sistêmica. O estroma virogênico (VS - local onde ocorre a produção dos vírions), presente no núcleo da célula infectada é indicado na figura (C) No início da infecção sistêmica, mais BVs são produzidos e se espalham infectando várias células no inseto (D) No final da infecção, ODVs são incluídos em corpos de oclusão e, em seguida, a célula morre liberando os corpos de oclusão para o meio ambiente, onde o ciclo de infecção se reiniciará. Fonte: Rohrmann, 2013.

\subsection{Baculovírus como vetor de expressão}

Os Baculovírus são muito utilizados como vetores para expressão de proteínas heterólogas. Sua facilidade de manipulação, segurança e baixo custo, fazem dessa ferramenta uma alternativa eficaz para a expressão de proteínas de interesse utilizando um sistema eucariótico. A aprovação do uso de vetores a base de baculovírus e células de 
inseto pela Agência Europeia de Medicamentos (EMEA) para a produção de vacinas abre caminho para a utilização do baculovírus também na terapia gênica (Airene, 2010).

O Autographa californica multiple nucleopolyedrovirus (AcMNPV) é o baculovírus mais estudado até o momento e os vetores de expressão comerciais são baseados nesse vírus (O’Reilly et al., 1992). Em 1972, foi isolado, no Brasil, o baculovírus Anticarsia gemmatalis multiple nucleopolyhedrovirus (AgMNPV) a partir de lagartas infectadas em plantações de soja (Allen \& Knell, 1977). Desde então, o AgMNPV tem sido estudado e utilizado no controle biológico de pragas da soja em diferentes países latino americanos (Moscardi et al., 2011). O seu potencial como vetor de expressão de proteínas heterólogas, bem como a utilização de suas proteínas para diferentes fins biotecnológicos, continuam sendo explorados e caracterizados. Em 2014, foram analisadas as diversidades genéticas de isolados de AgMNPV coletados de diferentes regiões da América do Sul, essa análise foi baseada na avaliação dos 4 genes pif (pif 1, pif 2, pif 3 and pif 4) de baculovírus. Esse estudo mostrou que os genes pif continuam estáveis apesar de mais de 20 anos de uso desse baculovírus no combate a lagarta da soja (Ferreira et al., 2014). Outro estudo importante utilizando AgMNPV foi a análise proteômica das partículas BV e ODV desse baculovírus. Esse estudo pode ajudar no melhoramento do uso de AgMNPV como biopesticida ou como ferramenta na expressão de proteínas heterólogas (Braconi et al., 2014).

O método mais simples de construção de um vetor de expressão baseado em baculovírus é a troca do gene da poliedrina por um gene heterólogo sob o comando do promotor da poliedrina (polh) (Miller et al., 1983). Vários vetores foram desenvolvidos no uso desse sistema para expressão de proteínas (Kost et al., 2005). Entre esses vetores, 
alguns são capazes de incorporar uma proteína heteróloga ao corpo de oclusão (Je et al., 2003) pela fusão do gene de interesse ao gene da poliedrina, além de possuírem o gene da poliedrina selvagem. Esses vetores capazes de expressar a poliedrina fusionada a outra proteína são usados para expressar corpos de oclusão que proporcionam a purificação rápida e fácil da proteína recombinante através de gradiente de sacarose (O’Reilly et al., 1992). Ardisson-Araújo et al. (2013) expressaram a proteína de capsídeo do “Garlic miteborne filamentous virus" (GarMbFV) fusionada com a poliedrina de AcMNPV em células de inseto. A proteína de fusão construída foi eficientemente expressa em células de inseto, formando corpos de oclusão e detectada com um anticorpo específico para cauda de histidina (presente no poliedro recombinante formado) e anti-poliedrina.

Além da fusão do gene da proteína de interesse com o gene da poliedrina, outras técnicas podem ser aplicadas para a expressão de proteínas de interesse usando baculovírus e células de inseto. Algumas dessas técnicas já são amplamente utilizadas na indústria, como a produção de VLPs ("Virus like particles") de diferentes vírus com fins biofarmacológicos (Yamaji, 2014) e também a técnica de "Display" de proteínas heterólogas na superfície de BVs de baculovírus. Essa técnica consiste na fusão do gene da proteína de interesse com o gene da proteína de envelope GP64 de baculovírus (Grabherr \& Ernst, 2010; Mäkelä \& Oker-Blom, 2006). Esta versatilidade na expressão de proteínas de interesse confirmam a eficiência do uso de células de inseto e baculovírus na expressão de proteínas heterólogas. 


\section{Capítulo I - Expressão de proteínas do vírus da febre amarela fusionadas à proteína do envelope de baculovírus}

\section{Introdução}

\subsection{Febre Amarela}

A febre amarela (FA) é uma doença infecciosa transmitida por mosquitos contaminados com o vírus da febre amarela. Essa doença é endêmica em países de clima tropical ou subtropical. O vírus da febre amarela é um arbovírus (vírus transmitido por vetor artrópode) pertencente à família Flaviviridae do gênero Flavivirus (Lindenbach et al., 2007; Volk et al., 2009). Também pertencem a esse gênero, os vírus causadores das doenças febre do Nilo, encefalite japonesa, dengue (tipos 1-4), Zika, entre outros (Mackenzie et al., 2004).

O vírus da FA se replica inicialmente nos linfonodos e, após a disseminação sistêmica, o vírus continua a se replicar principalmente no fígado, baço e medula óssea. A infeção pelo vírus da febre amarela no homem pode resultar em infecção assintomática até formas extremas que são invariavelmente fatais. A forma leve tem sintomatologia parecida com outras doenças infecciosas comuns como malária e as hepatites virais. Essa forma caracteriza-se pela presença de febre moderada, cefaleia e indisposição. Esse quadro pode durar alguns dias e o paciente recupera-se sem sequelas. Na forma moderada os mesmos sinais e sintomas da forma leve acontecem, porém com maior intensidade e duração. Epistaxe (sangramento ou hemorragia nasal), leve albuminúria e subicterícia podem acontecer. Na forma mais grave da doença (maligna) todos os sinais clássicos da 
doença estão presentes e falência hepato-renal é observada. Nesta fase o paciente pode evoluir para as manifestações hemorrágicas da doença (Vasconcelos, 2003). Tais aspectos provocaram uma grande preocupação de saúde pública durante séculos (Fields et al., 2007). A maioria das pessoas com a forma leve e moderada da doença recuperam-se sem sequelas a longo prazo. Para aqueles com sua forma grave, envolvendo disfunção hepatorenal, a duração da doença é variável e a letalidade é de 20\% a 50\% (Monath et al., 2008).

\section{2. Epidemiologia}

O vírus é mantido na natureza por meio de transmissão entre primatas nãohumanos e mosquitos hematófagos, principalmente pertencentes aos gêneros Haemagogus e Aedes na América do Sul e África. Os seres humanos são infectados esporadicamente quando picados por mosquitos silvestres (África: Aedes africanus; América do Sul: Haemagogus spp. e Sabethes spp.) que previamente se alimentaram de um macaco virêmico (a chamada febre amarela silvestre), mas também podem servir como hospedeiros para a transmissão inter-humana, principalmente pelo Aedes aegypti (a chamada febre amarela urbana) (Monath \& Vasconcelos, 2015). Na África, os ciclos silvestre e urbano podem ser interligados por um ciclo intermediário que ocorre em torno de pequenas comunidades e envolve mosquitos semi-domésticos Aedes ssp. (Mutebi \& Barrett, 2002) (Figura 3). 


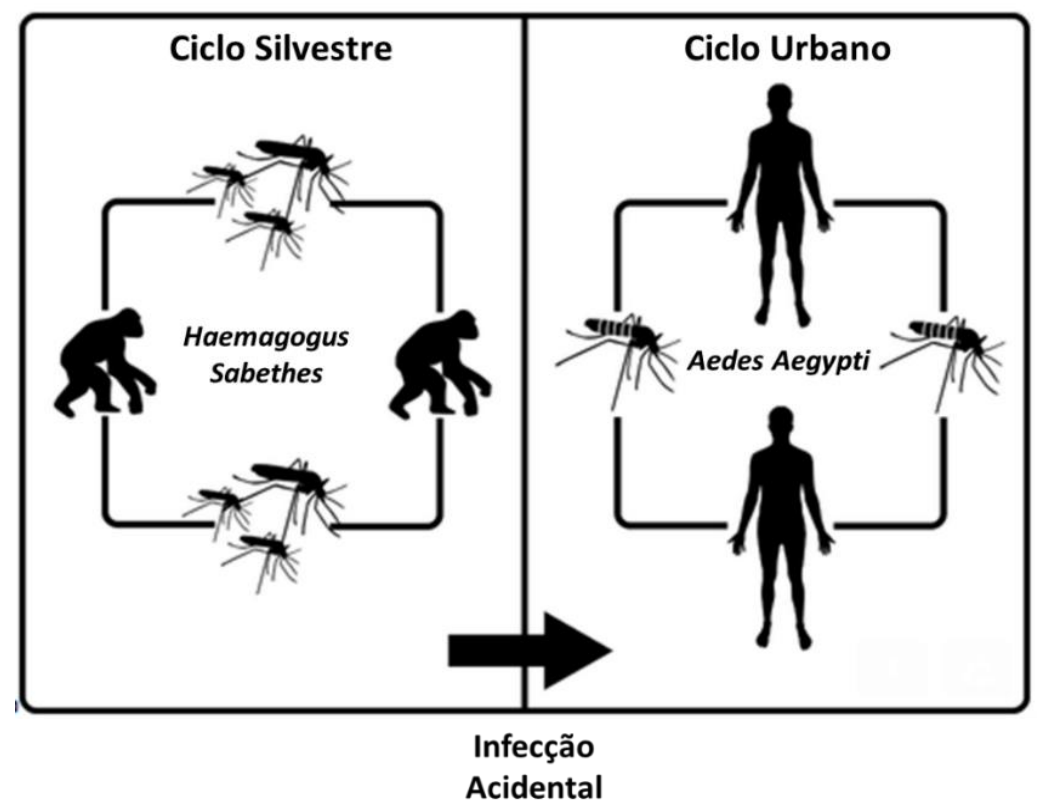

Figura 3. Ciclos epidemiológicos (silvestre e urbano) da febre amarela. O ciclo Silvestre ocorre quando primatas não humanos são picados por mosquitos dos gêneros Haemagogus e Sabethes infectados. A infecção acidental ocorre quando um humano entra na área de ciclo silvestre e é picado acidentalmente por mosquitos infectados. No ciclo urbano, a transmissão e disseminação do vírus é feita por mosquitos Aedes aegypti.

A febre amarela é endêmica em 44 países nas regiões tropicais da África e América do Sul. A maioria dos casos (90\%) ocorre na África, porém a América do Sul é hoje considerada a área de maior risco de epidemias urbana, onde estima-se a ocorrência de 300 casos anuais. Uma análise recente de fontes de dados africanos mostrou números semelhantes, de 84.000 - 170.000 casos graves e 29.000 - 60.000 mortes devido a febre amarela para o ano de 2013 (Vasconcelos, 2003; WHO, 2014).

Nas Américas, entre 1985 e 2012, 95\% dos casos de FA foram registrados no Peru (54\%), Bolívia (18\%), Brasil (16\%) e Colômbia (7\%). Entretanto, outros países latinoamericanos apresentam condições favoráveis à transmissão da doença. O número de casos de FA no mundo tem aumentado ao longo das últimas duas décadas, em função da 
diminuição da imunidade da população à infecção, da colonização de ambientes silvestres, dos movimentos migratórios humanos e das mudanças climáticas. No Brasil, entre 1999 e 2013, foram registrados 405 casos humanos com letalidade de 44,9\% (Ministério da Saúde, 2015).

\subsection{Diagnóstico}

O diagnóstico é feito por isolamento do vírus de amostras de sangue ou de tecido hepático, por detecção de antígeno em tecido (imunofluorescência e imunoperoxidase) ou por sorologia. Esses últimos são métodos complementares aos primeiros e as técnicas utilizadas são de captura de IgM (MAC- Elisa), inibição de hemaglutinação (IH), fixação do complemento (FC) e neutralização (TN). O MAC-Elisa, na maioria dos casos, permite o diagnóstico presuntivo com uma única amostra de soro, pois é bastante sensível para detecção de $\operatorname{IgM}$, dispensando o pareamento do soro (pesquisas sorológicas realizadas em diferentes dias para avaliar se houve conversão sorológica). Técnicas de biologia molecular para detecção de antígenos virais e/ou ácido nucléico viral [reação em cadeia de polimerase (PCR), imunofluorescência, imunohistoquímica e hibridização in situ], embora não utilizadas na rotina, são de grande utilidade (Ministério da Saúde, 2004).

As reações cruzadas entre o vírus amarílico e outros flavivirus são fatores que dificultam o diagnóstico sorológico, principalmente em áreas endêmicas de múltiplos flavivirus (Monath, 2001). Além disso, a utilização de teste imunoenzimático para a detecção de IgM circulante durante a infecção viral só é eficaz a partir do quinto dia após o início dos sintomas, quando os títulos de anticorpos IgM são evidenciados. Quando o objetivo é subsidiar as ações da vigilância epidemiológica e de controle de vetores, o 
prejuízo causado pela emissão de um resultado falso positivo é menor do que aquele causado pelo falso negativo. Por isso, a escolha por um teste diagnóstico deverá sempre levar em consideração a alta sensibilidade. A utilização de kits de diagnóstico rápido para a detecção de antígenos virais (como a proteína NS1 de flavivirus, que está presente no soro de indivíduos infectados desde o primeiro dia de doença, permanecendo na forma solúvel até o quinto ou sexto dia) pode ser uma importante ferramenta, se utilizados como teste de triagem de amostras destinadas ao isolamento de vírus (Silva et al., 2011).

\subsection{Tratamento e Prevenção}

Não há tratamento específico para a febre amarela, apenas cuidados de suporte para tratar a desidratação, insuficiência respiratória e febre. Infecções bacterianas associadas podem ser tratadas com antibióticos. O tratamento de suporte pode melhorar os resultados para pacientes em estado grave, mas é raramente disponível nas áreas mais pobres (WHO, 2014).

O método mais eficaz para se prevenir a febre amarela é a vacinação com a cepa 17D. Atualmente, duas subcepas são usadas na produção de vacinas: 17DD no Brasil e 17D-204 no resto do mundo (Galler et al, 2001). Uma única dose da vacina 17D consegue ativar o sistema imune através do estímulo de linfócitos $\mathrm{T}$ citotóxicos e linfócitos $\mathrm{T}$ auxiliares Th1 e Th2; além de induzir a produção de anticorpos neutralizantes (aqueles capazes de neutralizar o vírus). Assim, a vacinação contra FA é eficiente na ativação da resposta imune celular e humoral, conferindo proteção por mais de 30 anos (Monath, 2005). A vacina 17DD é administrada em dose única e confere proteção próxima a $100 \%$. Deve ser administrada a partir dos nove meses de idade, com reforço a cada 10 anos nas 
zonas endêmicas, de transição e de risco potencial, bem como para todas as pessoas que se deslocam para essas áreas. Em situações de surto ou epidemia, deve-se vacinar a partir dos seis meses de idade (Ministério da Saúde, 2004).

Como a vacina é produzida com vírus atenuado, não é recomendada a vacinação de pessoas com imunodeficiência, já que há riscos de reversão da virulência num hospedeiro com depressão do sistema imune (Vasconcelos, 2003). Além disso, o vírus é cultivado em embriões de galinha, e a vacina pode conter proteínas de ovo, o que pode ser prejudicial para pessoas com hipersensibilidade a proteínas de ovo (Chernin et al., 2011).

Entre 2007 e 2010, 57 milhões de pessoas foram vacinadas contra a febre amarela em 10 países de risco na África, e durante o mesmo período, 17 milhões de pessoas foram protegidas através da vacinação de emergência. Na década de 90, apesar de 50 anos de uso e mais de 500 milhões de doses distribuídas, novas preocupações de segurança sobre a vacina $17 \mathrm{D}$ de vírus atenuado surgiram, revelando que em raras circunstâncias, a vacina pode causar uma doença semelhante ao vírus selvagem (Monath \& Vasconcelos, 2015).

1.5. Vírus da febre amarela - Estrutura, processamento e função das proteínas

$\mathrm{O}$ vírus da febre amarela apresenta uma partícula esférica, com $50 \mathrm{~nm}$ de diâmetro, que possui no seu interior genoma constituído de uma molécula de RNA fita simples, sentido positivo, de aproximadamente 11.000 nucleotídeos, com CAP na extremidade 5' (modificação que ocorre na extremidade 5' do RNA, conferindo mais estabilidade a molécula, pois protege contra a ação de ribonucleases) e sem cauda poli-A 
na extremidade 3'. Possui regiões NCR (“Noncoding regions") nas extremidades 5' e 3', que são regiões conhecidas por possuírem estruturas internas que facilitam a tradução do genoma (Fields, 2007). Este genoma é organizado em uma única fase aberta de leitura (“Open Reading Frame" - ORF), essa ORF codifica uma poliproteína que depois é processada em proteínas estruturais (Capsídeo - C, Membrana - prM/M, Envelope - E) e não estruturais (NS1, NS2A, NS2B, NS3, NS4A, NS4B, NS5), (Brinton, 2002) (Figura 4).

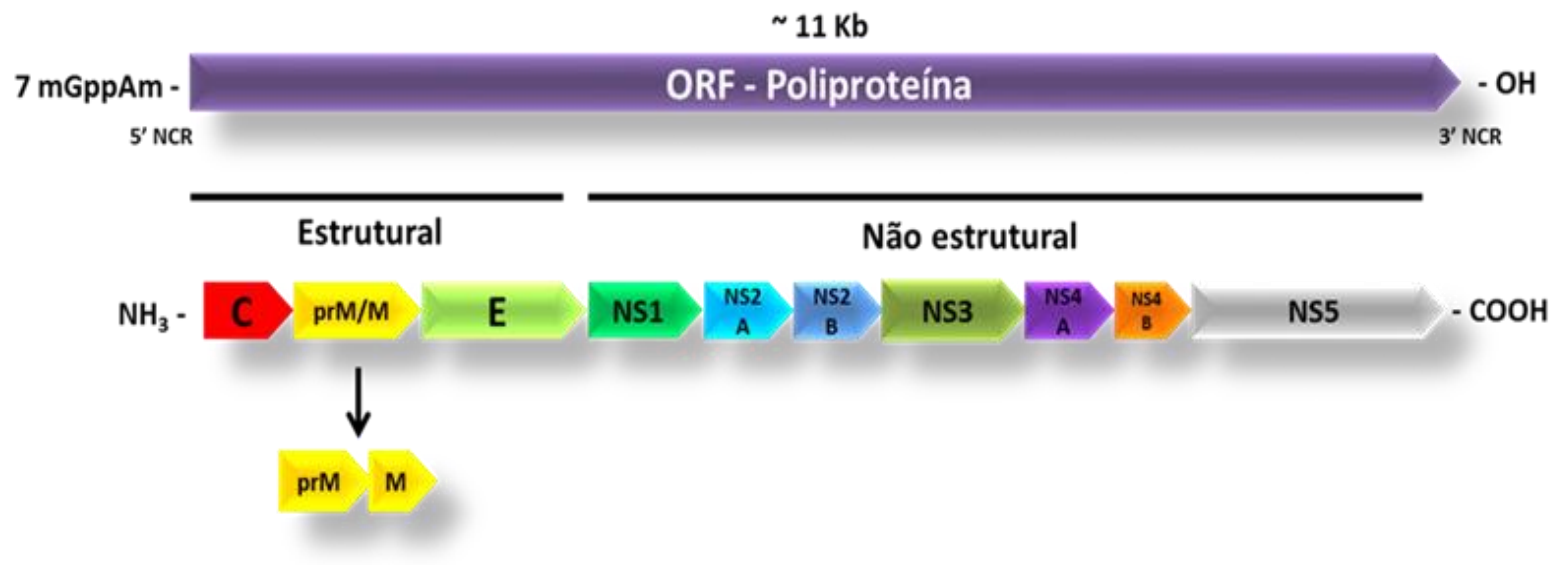

Figura 4. Estrutura genômica do vírus da febre amarela com genes estruturais, não estruturais (NS), regiões não codantes $5^{\prime}$ NCR e 3' NCR e a formação das proteínas virais após o processamento proteolítico.

A poliproteína é processada por uma combinação de proteases virais (NS2B NS3) e do hospedeiro (Furina) para gerar as proteínas virais maduras, esse processamento ocorre nas membranas do retículo endoplasmático (RE) (Rice, 1996) (Figura 5). 


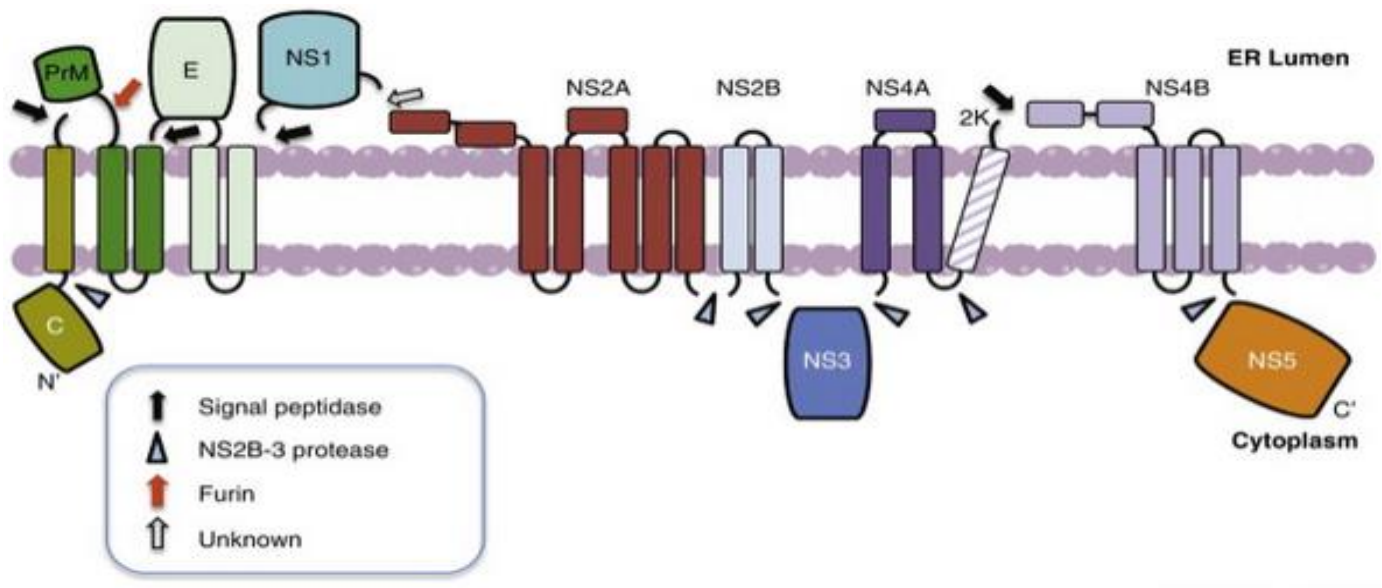

Figura 5. Processamento da poliproteína de flavivirus. A tradução do genoma viral resulta em uma poliproteína, que é clivada por proteases celulares e virais. As topologias propostas das proteínas virais com relação ao lúmen do RE e citoplasma estão indicadas na figura. A membrana do RE é mostrada em lilás, os domínios transmembrana de cada proteína são representados por cilindros e a ligação entre as proteínas são representadas pelas linhas pretas. Seta preta, azul e vermelha, representam os locais de clivagem por peptidase-sinal, NS2B -NS3 protease e furina, respectivamente. Seta aberta representa o local de clivagem de protease que ainda é desconhecida. Fonte: Apte-Sengupta et al., 2014.

As proteínas estruturais são incorporadas na partícula viral madura, enquanto as proteínas responsáveis pela replicação (proteínas NS) permanecem nas células infectadas. O envelope viral consiste de uma bicamada lipídica derivada da célula infectada com dímeros de proteína do envelope (E) ancorados na superfície do envelope por suas caudas hidrofóbicas. A proteína E é a maior proteína na superfície da partícula viral e é responsável pela entrada do vírus na célula do hospedeiro, mediando a ligação com receptor e fusão de membrana (Monath, 2001). Os receptores das células do hospedeiro envolvidos na ligação com a proteína E ainda são desconhecidos. Porém alguns estudos mostraram o envolvimento do receptor sulfato de heparano e dos receptores das famílias 
TIM e TAM na infecção pelo vírus da FA (Perera- Lecoin et al., 2014). A proteína E é uma proteína de aproximadamente $53 \mathrm{kDa}$ sintetizada como proteína de membrana do tipo I, contendo 12 cisteínas conservadas que formam pontes dissulfeto e é N-glicosilada. Baseado na estrutura cristalográfica da proteína E (Rey et al., 1995), cada monômero de E é dividido em três domínios diferentes, I, II e III (Figura 6). O domínio I é o domínio que se estrutura na forma de $\beta$ - Barril, o domínio II tem uma estrutura alongada e fornece a maior parte do contato entre as subunidades ("domínio de dimerização") e o domínio III possui um dobramento do tipo "immunoglobulin-like". O peptídeo de fusão, que medeia a inserção da partícula viral na célula alvo, está localizado no domínio II (Fields, 2007).

A

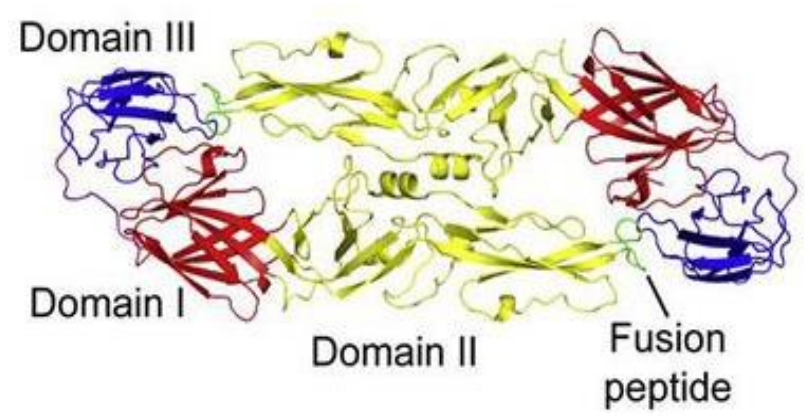

B

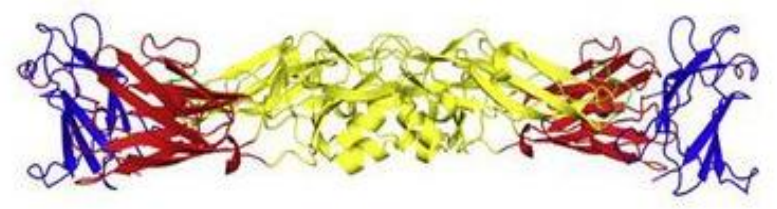

Figura 6. Esquema representativo de um dímero de proteína E do vírus da febre amarela. A) Dímero de E demonstração dos domínios I (vermelho), II (amarelo) e III (azul) e peptídeo de fusão B) Visão lateral do dímero de E (Fonte: Heinz \& Stiasny, 2012).

A proteína C - Capsídeo é uma proteína pequena de aproximadamente 11 kDa carregada positivamente (27\% Lys + Arg) (Chambers et al., 1990; Lindenbach et al., 
2007). É a proteína menos conservada entre os flavivirus, tem função estrutural na partícula viral madura, ao mesmo tempo, realiza um papel essencial na montagem da partícula viral e processos de encapsidação. Porém, ainda é desconhecido como essa proteína recruta o RNA viral durante a morfogênese da partícula viral. Em 2009, foi mostrado que a interação da proteína $\mathrm{C}$ de DENV com gotículas de lipídios ("lipid droplets") é requerida para a formação da partícula viral (Samsa et al., 2009).

As proteínas não estruturais possuem funções diferentes e essenciais na replicação viral. A proteína NS1 tem uma massa molecular de 46 - 55 kDa a depender do seu estado de glicosilação, ocorre em várias formas oligoméricas e é encontrada em diferentes locais celulares: associada à membrana celular nos compartimentos vesiculares dentro da célula ou na superfície celular (forma monomérica), também é altamente secretada em uma forma extracelular associada a lipídios - (forma hexamérica) (Akey et al, 2014). NS1 contém sítios de N-glicosilação e possui 12 cisteínas conservadas que formam pontes dissulfeto (Fields, 2007). NS1 é inicialmente expressa em associação com o retículo endoplasmático (ER) como parte da poliproteína que é produzida depois da tradução do genoma de flavivirus. Uma sequência sinal na extremidade C-terminal da glicoproteína E encaminha NS1 para o lúmen do RE, dentro do RE NS1 é clivada tanto na sua extremidade $\mathrm{N}$ e C-terminal gerando uma subunidade monomérica hidrofílica. Este monómero é modificado pela adição de carboidrato rico em manose em sítios múltiplos e rapidamente forma uma espécie dimérica, que possui um caráter hidrofóbico e resulta em associação com membrana (Muller \& Young, 2013). NS1 é essencial para a replicação do genoma de flavivirus, possivelmente através de interações com as proteínas transmembranares NS4A e NS4B (Akey et al., 2014). 
NS2A é uma proteína hidrofóbica pequena, cerca de $22 \mathrm{kDa}$ (Chambers et al., 1989). É encontrada em associação às membranas celulares e está envolvida no processamento e maturação da proteína NS1 (Vasconcelos, 2003); na montagem dos vírions; na replicação do RNA, além de interagir com a região $3 `$ NCR (Lindenbach et al., 2007).

NS2B também é uma proteína pequena, cerca de $14 \mathrm{kDa}$, também é uma proteína associada a membrana. NS2B forma um complexo estável com NS3 e é um cofator necessário para a atividade de NS2B-NS3 serino protease. Mutações em resíduos conservados da proteína NS2B têm efeitos drásticos na clivagem autoproteolítica da junção NS2B-NS3 e, consequentemente, na clivagem de outras proteínas que são processadas por essa protease viral (Fields, 2007).

NS3 é a segunda maior proteína viral, possui massa molecular entre 68-70 kDa sendo altamente conservada entre os flavivirus (Lindenbach et al., 2007). NS3 contém atividades de protease (usando NS2B como co-factor), RNA helicase, e de nucleotídeo trifosfatase (NTPase). Por causa das suas atividades enzimáticas e seu papel crítico na replicação viral e transformação da poliproteína, NS3 constitui um alvo promissor para o desenvolvimento de medicamento para terapia antiviral (Assenberg et al., 2009).

NS4A é uma proteína altamente hidrofóbica de $16 \mathrm{kDa}$, contém uma sequência inicial (resíduos 1 a 49) que, aparentemente, não interage com as membranas e parece funcionar como um co-factor de NS3; posteriormente apresenta três regiões hidrofóbicas (os resíduos 50 a 73, resíduos 76-89 e os resíduos 101-127) que estão fortemente associados a membranas, uma pequena volta que expõe o local de clivagem NS4A (resíduos 123-130) e um fragmento C - terminal chamado 2k que atua como a sequência 
sinal para a translocação da proteína NS4B para dentro do lúmen do RE. NS4A, em conjunto com outras proteínas virais e do hospedeiro, promove os rearranjos essenciais na membrana para a replicação viral. Interessantemente, demonstrou-se recentemente que a NS4A induz autofagia em células epiteliais aumentando a replicação viral (McLean et al., 2011; Nemésio et al., 2012).

NS4B é uma proteína de $27 \mathrm{kDa}$, também altamente hidrofóbica. NS4B é necessária para a replicação do vírus (Zou et al., 2014). No entanto, esta proteína não tem atividade enzimática relatada e seu papel exato durante o ciclo de replicação viral ainda não é muito bem entendido. Recentemente foram identificados, na proteína NS4B (DENV), determinantes essenciais para interação com NS3 e replicação do RNA viral (Chatel-Chaix et al., 2015).

A proteína NS5 é a maior proteína viral com massa molecular de 103-104 kDa (Chambers et al., 1990; Lindenbach et al., 2007). A região N-terminal compreende um domínio RNA metiltransferase - MTase (envolvido na metilação da estrutura 5'cap RNA) e a região C-terminais abriga um domínio de RNA polimerase dependente de RNA (RdRp). Estes dois domínios estão ligados através de uma sequência de aminoácidos não muito conservada (Davidson, 2009).

1.6. Vírus da febre amarela - Replicação e montagem de novas partículas virais

A biossíntese viral inicia-se com a adsorção, ligação específica irreversível de uma glicoproteína viral a um constituinte da célula hospedeira (receptor) (Santos et al., 2002). As partículas virais de flavivirus entram nas células alvo por endocitose mediada por receptor e trafegam através de endossomos, onde o ambiente ácido desencadeia grandes 
mudanças conformacionais na glicoproteína de envelope (E) induzindo a fusão das membranas das células hospedeiras e virais, liberando o material genético para o interior celular (Fernandez-Garcia et al., 2009).

O RNA (fita simples de polaridade positiva) liberado codifica uma poliproteína precursora. Este polipeptídeo é co/pós-traducionalmente processado por proteases virais e do hospedeiro, como mostrado no item 1.5. Depois da entrada do material genético e a tradução da proteína a partir do genoma viral, NS5 RdRp realiza a síntese da fita de RNA de polaridade negativa a partir da fita de polaridade positiva. A fita de polaridade negativa serve como molde para a síntese de fitas de RNA polaridade positiva, que são utilizadas na montagem da progênie viral (Lim et al., 2015).

A Montagem do vírus ocorre no retículo endoplasmático (RE) e inicialmente leva à formação de partículas imaturas não infecciosas, que são formadas por estruturas membranosas contendo um complexo de proteínas prM - E. Após o transporte do vírion imaturo através da via celular exocítica, o complexo prM - E de proteínas sofre uma mudança conformacional, induzida pelo baixo $\mathrm{pH}$ na rede trans-Golgi (TGN), que permite prM ser clivada por proteínas furina antes que as partículas de vírus sejam liberadas da célula. Esta clivagem provoca um rearranjo importante de proteínas E na superfície da partícula, levando à formação de partículas maduras infecciosas, que carregam a proteína dimérica E em uma conformação metaestável (forma nativa) (Stiasny et al., 2009) (Figura 7). 


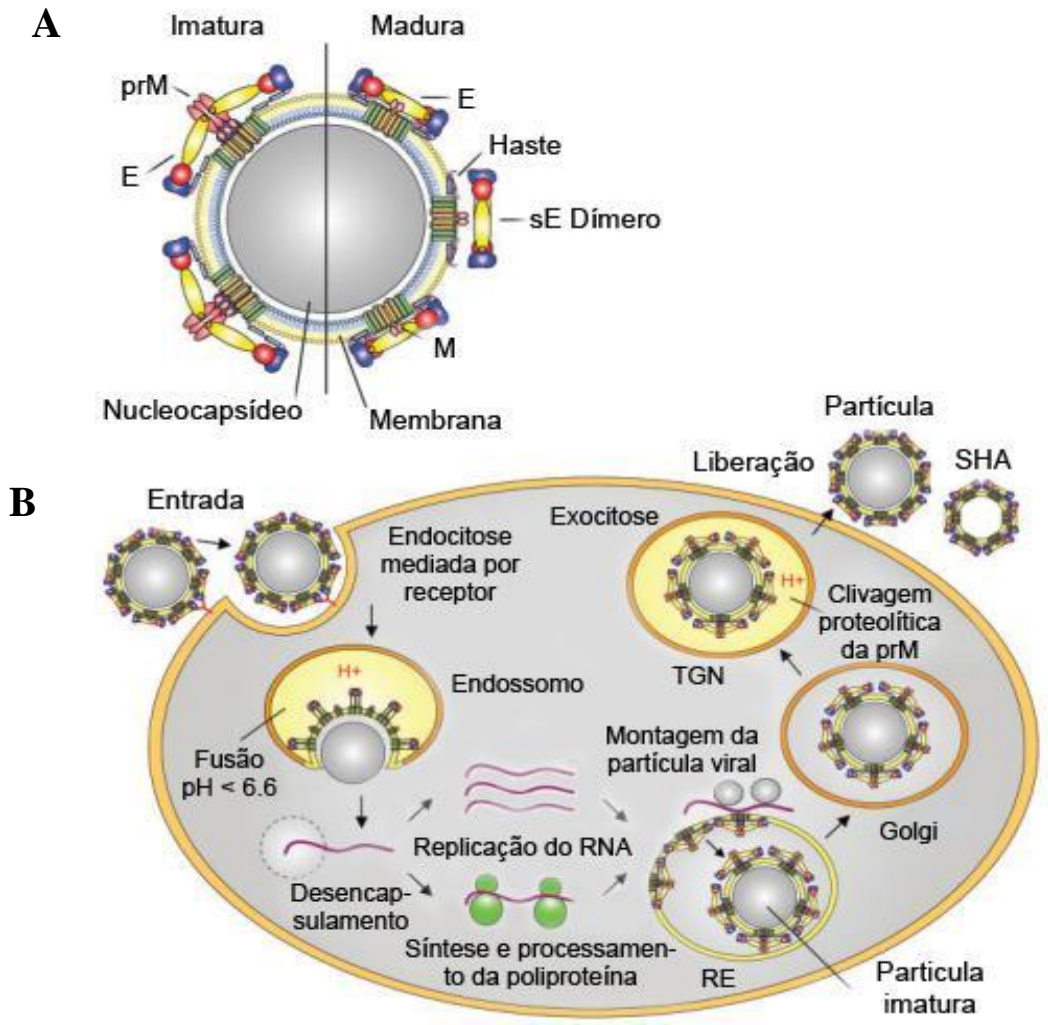

Figura 7. Representação esquemática da partícula de flavivirus e ciclo de infecção viral (A) Partícula de flavivirus: vírions imaturos contêm duas proteínas associadas à membrana (prM e E) que formam um complexo heterodimérico apertado. No curso de maturação do vírus, a proteína prM é clivada, resultando no rearranjo de $\mathrm{E}$ (vírions maduros). O produto de clivagem carboxi-terminal da prM (M) permanece associado com a membrana viral (B) Ciclo de infecção viral: entrada do vírus ocorre por endocitose mediada pelo receptor, e o pH ácido no endossomo induz alterações estruturais em E que levam a fusão da membrana e ao lançamento do nucleocapsídeo no citoplasma. Depois do desencapsulamento, a fita de RNA é traduzida para iniciar a replicação do vírus. Montagem do vírus ocorre no retículo endoplasmático (RE) e leva à formação de partículas imaturas (contendo prM) que são transportadas através de uma via exocítica. $\mathrm{O}$ pH ácido na rede trans-Golgi (TGN) provoca uma mudança conformacional irreversível no complexo prM-E, que é necessário para a maturação da partícula viral. Partículas maduras infecciosas são liberadas por exocitose. Partículas menores não infecciosas também são liberadas a partir de células infectadas, essas partículas são chamadas SHA (“Slowly sedimenting hemagglutinin”) (Stadler et al., 1997) Adaptado de: Stiasny \& Heinz, 2006. 
1.7. Proteína E e NS1 como proteínas imunogênicas

A proteína de Envelope (E) de flavivirus é o principal componente da superfície da partícula viral. É o imunógeno primário e desempenha o papel central na ligação aos receptores e fusão de membrana (Heinz \& Allison, 2003). O domínio III dessa proteína (EDIII) está envolvido na ligação ao receptor (possui a região de ligação a receptor) e contém regiões preferencialmente reconhecidas (epítopos) por anticorpos humanos essenciais para a neutralização específica do vírus (Chu et al., 2005) (Figura 8).

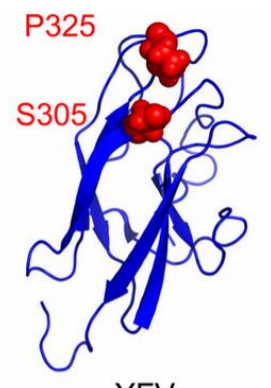

YFV

Figura 8. Epítopos neutralizantes no domínio III (EDIII) da proteína de envelope do vírus da febre amarela. Os aminoácidos reconhecidos por anticorpos neutralizantes são serina 305 (S305) e prolina 325 (P325) (Volk et al., 2009).

Estudos com outros flavivirus e anticorpos monoclonais têm demonstrado que anticorpos para cada um dos domínios pode levar a neutralização do vírus, embora aqueles dirigidos para EDIII parecem ter a maior atividade neutralizante específica (Vratskikh et al., 2013). O domínio III, por si só tem mostrado ser suficiente para induzir uma resposta imunitária protetora (Martina et al., 2008; Alonso-Padilla et al., 2011). Um estudo recente mostrou que a imunização com EDIII recombinante conseguiu proteger camundongos contra infecção por Encefalite japonesa, que também pertence ao gênero 
flavivirus, sugerindo que EDIII pode ser usado eficientemente para o desenvolvimento de vacinas (Fan et al., 2013).

Imunidade ao vírus da febre amarela (YFV - "Yellow fever virus") tem sido geralmente relacionada com a presença de anticorpos neutralizantes contra glicoproteína do envelope (E), no entanto, foi mostrado uma transferência passiva de anticorpos monoclonais (proteção temporária conferida pela transferência de imunoglobulinas) direcionados para a glicoproteína NS1, ausente no vírion (Schlesinger et al., 1990).

NS1 pode ser detectada dentro das células infectadas, na superfície celular, e é eficientemente secretada pelas células (Lindenbach \& Rice, 1997). NS1 é fortemente imunogênica, e o tipo específico de anticorpos anti-NS1 desempenham um papel na proteção contra a doença. Altos níveis de NS1 são encontrados na circulação de pacientes infectados com DENV durante a fase aguda da doença, demonstrando que os maiores níveis da proteína NS1 são detectados até o 9 dia após o início dos sintomas. (Alcon et al., 2002; Avirutnan et al., 2006). NS1 interage com múltiplos componentes de ambos os sistemas imunes inato e adaptativo, está envolvida na evasão do sistema imunitário e patogênese e é o principal marcador antigênico de infecção viral. Portanto, pode também ser alvo para o desenvolvimento de uma vacina recombinante ou para kits de diagnóstico precoce de FA (Akey et al., 2014).

\section{8. "Display" do EDIII de FA na superfície de baculovírus}

Um dos métodos mais utilizados para produção de proteínas no sistema baculovírus/células de inseto com potencial para uso como vacinas de subunidade é o método de "Display" na superfície da partícula viral de baculovírus. Para isso, é 
necessário fusionar o gene da proteína GP64 e o gene da proteína de interesse. No caso do baculovírus Autografa californica multiple nucleopolyhedrovirus (AcMNPV), a partícula viral BV - "Budded virus" possui duas proteínas de envelope, a GP64 e a Ac23 (Lung et al., 2003; Rohrmann, 2013). A proteína GP64 é uma glicoproteína altamente abundante no envelope da partícula BV. É uma proteína essencial e está envolvida em duas etapas durante a entrada da partícula BV na célula: adsorção do vírion e fusão de membrana (Blissard \& Wenz, 1992). No envelope da partícula BV de AcMNPV também se encontra um homólogo da proteína F de baculovírus, a proteína Ac23 (Lung et al., 2003). As proteínas F são proteínas de envelope encontradas nos baculovírus de Lepidoptera. Em alguns baculovírus como Spodoptera exigua multiple nucleopolyhedrovirus (SeMNPV), a proteína F é funcional e atua como proteína de fusão de membrana, bem como a proteína GP64 (Pearson et al., 2000). No AcMNPV, a proteína Ac23 parece não ser uma proteína funcional e estudos mostraram que a deleção do gene Ac23 não possui efeito na produção e infectividade viral in vitro (Lung et al., 2003).

A ideia de um sistema de expressão utilizando a proteína GP64 de baculovírus surgiu a partir da característica de "brotamento" da partícula viral durante o ciclo de infecção. O fenótipo BV faz a infecção célula-célula, sendo responsável assim pela propagação da infecção no inseto. Quando o BV se liga a receptores localizados na superfície celular acontece a endocitose da partícula viral. A vesícula endocítica é altamente acidificada e induz a mudança conformacional na GP64, fazendo com que o envelope viral se funda com a membrana endossomal, liberando o nucleocapsídeo no interior celular. O nucleocapsídeo entra no núcleo onde o DNA é replicado e os novos nucleocapsídeos da progênie viral são montados. Enquanto isso novas proteínas GP64 e 
Ac23 (no caso do AcMNPV) são sintetizadas no retículo endoplasmático, precessadas no aparelho de Golgi e endereçadas para a superfície celular. Quando os novos nucleocapsídeos produzidos no núcleo saem em direção ao exterior celular, eles "brotam” do interior celular para o exterior, levando junto com o novo envelope, proteínas GP64 e F (Ac23) dispostas na superfície da partícula (Rohrmann, 2013). Assim, uma vez que a proteína de interesse esteja fusionada com GP64 ou proteína F, também será apresentada na superfície celular.

A eficiência dessa técnica vem sendo aprimorada continuamente. Nos últimos anos, estudos com a proteína GP64, mostraram que somente algumas regiões gênicas são essenciais para o correto funcionamento da proteína, como entrada na célula, fusão celular e expressão na superfície da célula (Li \& Blissard, 2009; Monsma et al., 1996). Portanto, a proteína GP64 tem sido reduzida a três regiões essenciais, PS (peptídeo sinal), TM (domínio transmembrana) e DCT (domínio da cauda citoplasmática). O PS é a região que codifica o sinal para envio da proteína à superfície celular, a região TM que possui aproximadamente 16 a 23 aminoácidos, é uma região praticamente conservada, possui aproximadamente $80 \%$ de identidade entre os baculovírus. Estudos mostraram que a região TM da GP64 é crítica para a função da proteína. Estudos mais recentes demonstram ainda que a região TM é essencial para a função de proteína de fusão da GP64. Já a região DCT, que possui de 3 a 8 aminoácidos, é uma região essencial para o eficiente brotamento da partícula viral (Li \& Blissard, 2009; Oomens \& Blissard, 1999). Essas regiões essenciais têm sido utilizadas para construir uma GP64 "truncada", que serve como vetor para fusão com proteínas de interesse, obtendo-se assim, um vetor menor e funcional para "Display" de proteínas heterólogas na superfície de baculovírus. 
Esse método foi escolhido para a expressão de EDIII de FA e vem crescendo significativamente nos últimos anos devido aos baixos custos e segurança. Várias proteínas heterológas, provenientes de diferentes vírus têm sido expressas usando esse sistema, consolidando a técnica como ferramenta biotecnológica para a produção de vacinas de subunidade.

\section{Objetivo}

Esse trabalho tem como objetivo geral a expressão de proteínas imunogênicas do vírus da Febre amarela na superfície de partículas de baculovírus (BVs) e também fusionadas à poliedrina, e sua análise como candidatas a vacinas recombinantes.

\subsection{Objetivos específicos}

- Construção dos vetores para fusão de proteínas recombinantes e GP64 de AcMNPV e AgMNPV

- Clonagem das sequências gênica de EDIII FA nesses vetores

- Clonagem de EDIII em vetor que possui sítio de clonagem para fusão com o gene da poliedrina de AcMNPV

- Construção dos baculovírus recombinantes contendo os genes de interesse

- Análise da expressão das proteínas recombinantes em células de inseto

- Avaliação do perfil imunológico de camundongos imunizados com as partículas e proteínas recombinantes 


\section{Material e métodos}

\subsection{Vírus e células}

Os vírus AcMNPV e AgMNPV e baculovírus recombinantes derivados do AcMNPV na forma de bacmídeo bMON14272” Bac-to-Bac ${ }^{\circledR}$ "Baculovirus Expression System" da empresa Invitrogen foram utilizados nesse trabalho.

Os vírus selvagens e os recombinantes foram propagados em cultura de células derivadas de Trichoplusia ni (BTI-Tn5B1-4 ou Tn5B) (Granados et al., 1994) ou células derivadas de Spodoptera frugiperda (Sf9) (Vaughn et al., 1977).

Células Sf9 - ET (“Easy Titer”) foram utilizadas para titulação de todos os vírus utilizados neste trabalho (Hopkins \& Esposito, 2009).

Células de Escherichia coli DH5- $\alpha$ (Invitrogen) foram utilizadas como hospedeiras para a maior parte dos plasmídeos utilizados no presente trabalho.

Os experimentos envolvendo Bac-to-Bac ${ }^{\circledR}$ "Baculovirus Expression System" (Invitrogen) foram utilizadas células Escherichia coli (E.coli) DH10Bac (Invitrogen).

3.2. Construção dos vetores para expressão das proteínas recombinantes na superfície de baculovírus

Foram sintetizadas quimicamente as regiões essenciais (Promotor - pGP64, Peptídeo sinal de endereçamento - PS, Domínio da cauda citoplasmática - DCT e Transmembrana - TM) (IDT ${ }^{\circledR}$ - Integrated DNA Technologies) da proteína de envelope GP64 dos baculovírus AcMNPV e AgMNPV, uma sequência de seis histidinas (6xHis) e 
um sítio da enzima de restrição BamHI, que foi utilizado para a inserção dos genes de interesse (Figura 9).

A

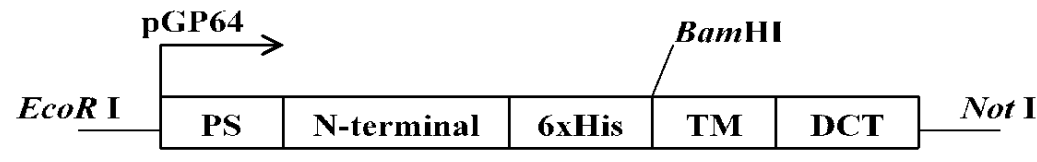

GP646xHisAc

B

$540 \mathrm{pb}$

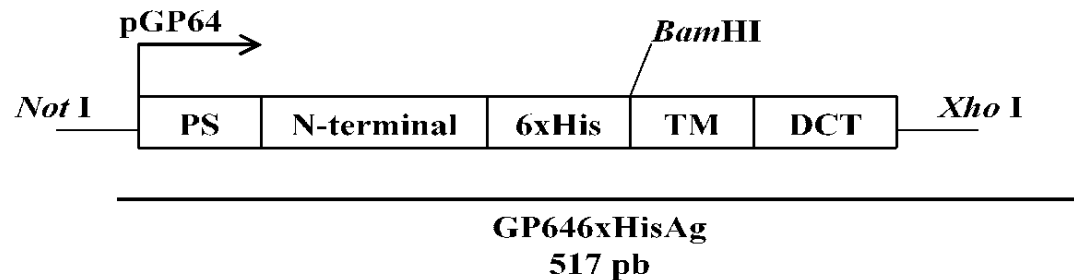

Figura 9. Esquema representativo dos cassetes de expressão para fusão com a proteína GP64 de baculovírus.

A) Cassete de expressão para fusão de genes heterólogos com as regiões essenciais (Promotor - pGP64, peptídeo sinal de endereçamento - PS, domínio transmembrana - TM e domínio da cauda citoplasmática DCT) do gene da proteína GP64 do baculovírus AcMNPV B) Cassete de expressão para fusão de genes heterólogos com as regiões (Promotor - pGP64, peptídeo sinal de endereçamento - PS, domínio transmembrana - TM e domínio da cauda citoplasmática - DCT) do gene da proteína GP64 do baculovírus AgMNPV.

Esses cassetes de expressão foram utilizados como molde para uma reação de PCR, onde foram utilizados: $2,5 \mu 1$ do tampão de reação $10 \mathrm{X}$ da enzima Taq DNA polimerase (Platinum ${ }^{\circledR}$ Taq DNA Polymerase Kit, Invitrogen), $0,75 \mu 1$ de $\mathrm{MgCl}_{2}$ (solução estoque $50 \mathrm{mM}$ ), 0,5 $\mu 1$ da mistura dos quatro dNTPs (solução estoque $10 \mathrm{mM}$ ), 0,5 $\mu 1$ do oligonucleotídeo pGP64Ac Fusion F ou pGP64Ag Fusion F (solução estoque $10 \mu \mathrm{M}$ ) 


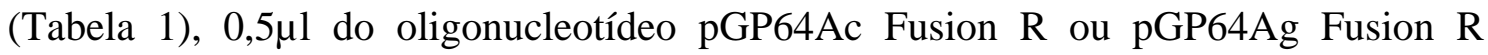
(solução estoque $10 \mu \mathrm{M}$ ) (Tabela), $1 \mu \mathrm{l}$ do DNA - Cassete sintetizado ( $60 \mathrm{ng} / \mu \mathrm{l}), 2 \mathrm{U}$ (unidades) da enzima Taq DNA polimerase (Platinum ${ }^{\circledR}$ Taq DNA Polymerase, Invitrogen) e água “milli-Q" para um volume final de $25 \mu \mathrm{l}$. O seguinte programa foi utilizado: $94^{\circ} \mathrm{C} / 1 \mathrm{~min} \mathrm{~s}, 30$ ciclos de $94^{\circ} \mathrm{C} / 30 \mathrm{~s}, 55^{\circ} \mathrm{C} / 30 \mathrm{seg}, 72^{\circ} \mathrm{C} / 1 \mathrm{~min}$ e $72^{\circ} \mathrm{C} / 2 \mathrm{~min}$ para o término da extensão. O resultado da PCR foi analisado por eletroforese em gel de agarose $0.8 \%$ de acordo com o protocolo descrito em Sambrook et al. (1989).

Tabela 1. Oligonucleotídeos utilizados no trabalho.

\begin{tabular}{|l|l|}
\hline \multicolumn{1}{|c|}{ Oligonucleotídeos } & \multicolumn{1}{c|}{ Sequência 5' $\rightarrow \mathbf{3}$} \\
\hline pGP64Ac Fusion $\mathrm{F}$ & GAATCCTTATCAATTAAGATAAAAAGATAAGATTATTAATC \\
\hline pGP64Ac Fusion R & GCGGCCGCAATAATGATACAATTTTTATTATTACATTTAATAT \\
\hline pGP64Ag Fusion F & GCGGCCGCGTCGAGTTTATATATTGCAAGATAAGATATAAG \\
\hline pGP64Ag Fusion R & CTCGAGTTAACGGCGTGTACACATCATAAAAGCTAAAAAGCGT \\
\hline YFEDIIIPOLFPCIIF & ACATGTCAAGGGGACATCCTACAA \\
\hline YFEDIIIPOLFPCIIR & ACATGTTTTGTGCCACTGGTAAGTGA \\
\hline
\end{tabular}

Os fragmentos de DNA com os tamanhos esperados (540 bp - GP646xHisAc ou 517 bp - GP646xHisAg), correspondentes à amplificação dos cassetes de expressão, foram analisados por eletroforese em géis de agarose a $0.8 \%$ (Sambroock et al., 1989) e extraídos do gel, usando o Kit GFX DNA and Gel Band Purification (GE) seguindo instruções do fabricante. Os fragmentos extraídos foram clonados no vetor de clonagem 
pGEM $^{\circledR}$-T Easy Vector - Promega (Figura 10), seguindo as instruções do fabricante (dados não mostrados), gerando os plasmídeos pGEM GP646xHisAc e pGEM GP646xHisAg. A confirmação da obtenção dos plasmídeos foi feita por sequenciamento dos cassetes de expressão (Macrogen, Coréia do Sul).

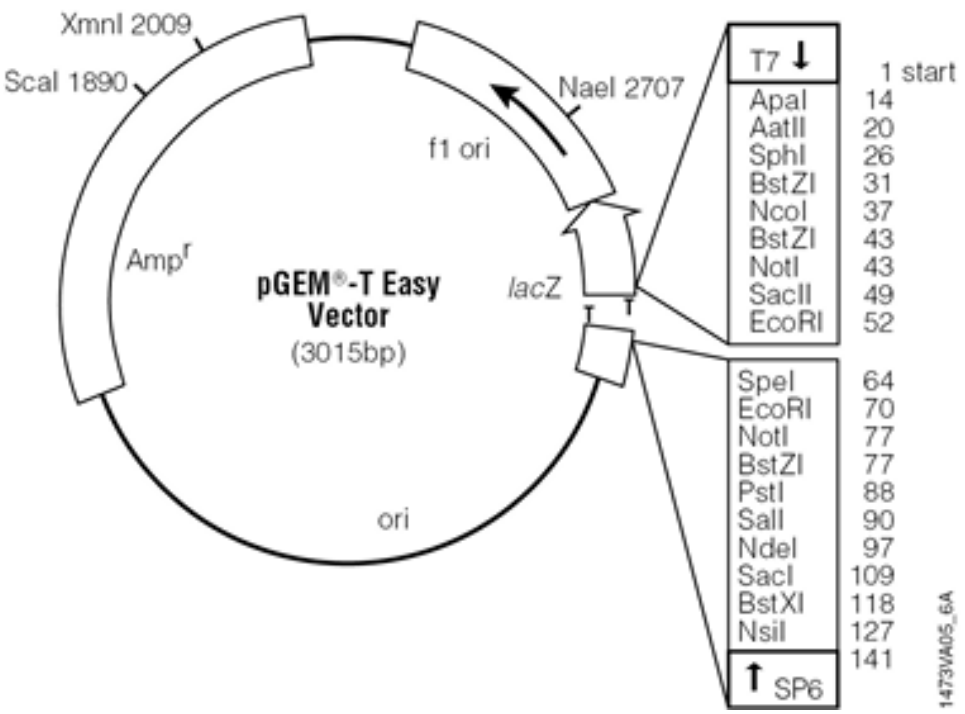

Figura 10. Esquema representativo do plasmídeo $\mathrm{pGEM}^{\circledR}$-T Easy - Promega. Os sítios para enzima de restrição, o gene lacZ e o gene de resistência ao antibiótico ampicilina então indicadas na figura.

Esses plasmídeos foram digeridos com as enzimas de restrição $\operatorname{Sph}$ I e $\operatorname{Sac}$ I (5 $\mu 1$ de DNA 30 ng/ $\mu 1,1 \mathrm{U}$ de cada enzima - Promega, $2 \mu \mathrm{l}$ BSA 10X, $2 \mu 1$ do tampão de reação 10X, e água “milli-Q" para um volume final de $20 \mu 1$ ). Da mesma forma e utilizando as mesmas enzimas, foi feita a digestão do plasmídeo pFASTBAC ACCI (Figura 11). A reação para digestão com as enzimas de restrição foi mantida a $37^{\circ} \mathrm{C}$ por 16h ("overnight”). O plasmídeo pFASTBAC ACCI é similar ao plasmídeo 
comercialmente vendido $\mathrm{pFastBac}^{\mathrm{TM}}$ (Invitrogen), exceto pela ausência do promotor da poliedrina, que foi retirado anteriormente por digestão com enzima de restrição Acc I.

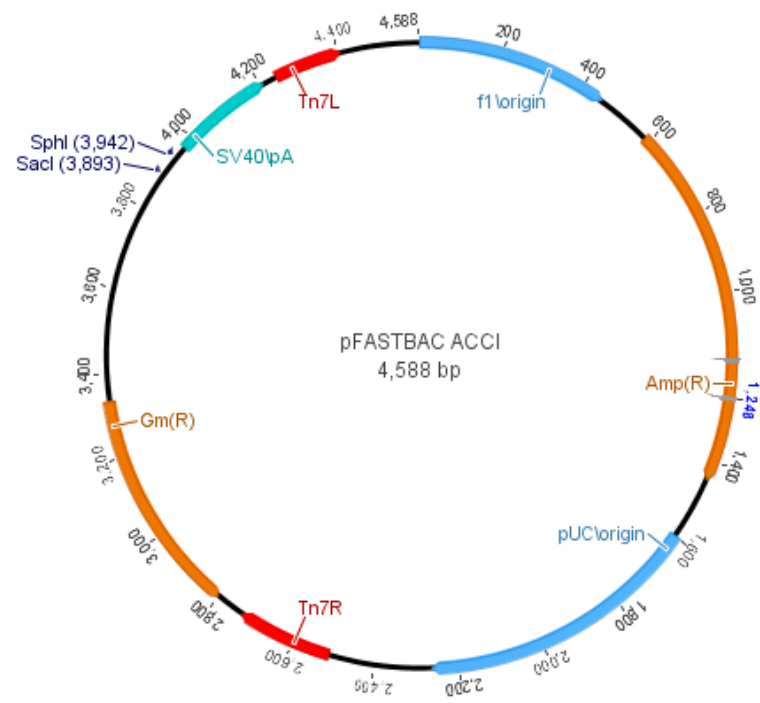

Figura 11. Esquema representativo do plasmídeo pFASTBAC ACCI. Na figura é possível ver os sítios de restrição das enzimas Sac I e Sph I, que foram utilizados para clonagem dos cassetes de expressão, gene de resistência a Ampicilina (Amp), gene de resistência a Gentamicina (Gm), regiões de transposição Tn7R e Tn7L, sinal de poliadenilação SV40 pA, origem de replicação pUC e origem de replicação f1 (esse plasmídeo possui duas origens de replicação para gerar um maior número de cópias). Esquema produzido no programa Geneious (Biomatters Limited).

O plasmídeo pFASTBAC ACCI digerido foi utilizado em reação de ligação com os fragmentos digeridos GP646xHisAc e GP646xHisAg utilizando a enzima T4 DNA ligase (Promega) seguindo protocolo do fabricante. Foi realizada uma transformação por choque térmico (Sambrook et al., 1989). Para essa transformação foram utilizadas células Escherichia coli DH5a quimio-competentes comerciais. Os clones resultantes foram selecionados pela resistência aos antibióticos ampicilina e gentamicina. Posteriormente, foi feita uma purificação por lise alcalina (Sambrook et al., 1989), onde $1 \mathrm{ml}$ de pré- 
inóculo foi centrifugado $30 \mathrm{~s}$ a $14.000 \mathrm{rpm}$ (Centrífuga 5418 - Eppendorf), o sobrenadante foi removido e o precipitado ressuspendido em $100 \mu$ l de solução I (50mM glicose, 25mM Tris-HCl pH 8, 10 mM EDTA pH 8) seguido de incubação em gelo por 2 min, foram acrescentados $200 \mu 1$ de solução II (NaOH 0,2 M, SDS 1\%) e incubado 5 min no gelo, acrescentados mais $150 \mu \mathrm{l}$ de solução III (acetato de potássio 5M, ácido acético glacial, $\mathrm{H}_{2} \mathrm{O}$ ) e incubado 20 min no gelo. Após incubação, a amostra foi centrifugada por 10 min a 14.000 rpm (Centrífuga 5418 - Eppendorf) e o sobrenadante transferido para outro tubo, ao sobrenadante foram acrescentados $200 \mu 1$ de clorofórmio, seguido de centrifugação por 5 min a 14.000 rpm (Centrífuga 5418 - Eppendorf). A fase superior formada na parte de cima do tubo foi coletada e transferida para outro tubo, onde foram adicionados $350 \mu \mathrm{l}(0,6 \%)$ de isopropanol, seguido de centrifugação por 10 min a 14.000 rpm (Centrífuga 5418 - Eppendorf). O sobrenadante foi descartado e ao precipitado foram adicionados $500 \mu \mathrm{l}$ de etanol $70 \%$, a amostra foi centrifugada por $10 \mathrm{~min}$ a $14.000 \mathrm{rpm}$ (Centrífuga 5418 - Eppendorf), o sobrenadante foi novamente descartado e o precipitado foi ressuspendido em $50 \mu l$ de água.

A confirmação da clonagem foi feita através de digestão com as enzimas de restrição $S p h$ I e $S a c$ I. Foram utilizados para essa reação de digestão $5 \mu 1$ de DNA plasmidial ( $30 \mathrm{ng} / \mu \mathrm{l}), 2 \mu \mathrm{l}$ do tampão de reação 10X (Promega), 1U (unidade) da enzima Sph I (Promega), 1U (unidade) da enzima Sac I (Promega) e água “milli-Q” para um volume final de 20 $\mu$ l. Os plasmídeos confirmados (pFASTBACACCI GP64 Ac e pFASTBACACCI GP64 Ag) foram então, sequenciados (Macrogen, Coréia do Sul). 
3.3. Construção dos plasmídeos para expressão do domínio III da proteína de envelope do vírus da febre amarela na superfície da partícula BV de baculovírus

O gene EDIII (Envelope - FA Domínio III) foi sintetizado quimicamente (IDT ${ }^{\circledR}$ Integrated DNA Technologies), a síntese gênica foi feita já fusionando as regiões essenciais da proteína GP64 de AcMNPV e AgMNPV a esse gene, gerando dois cassetes de expressão EDIIIGP646xHisAc e EDIIIGP646xHisAg (Figura 12).

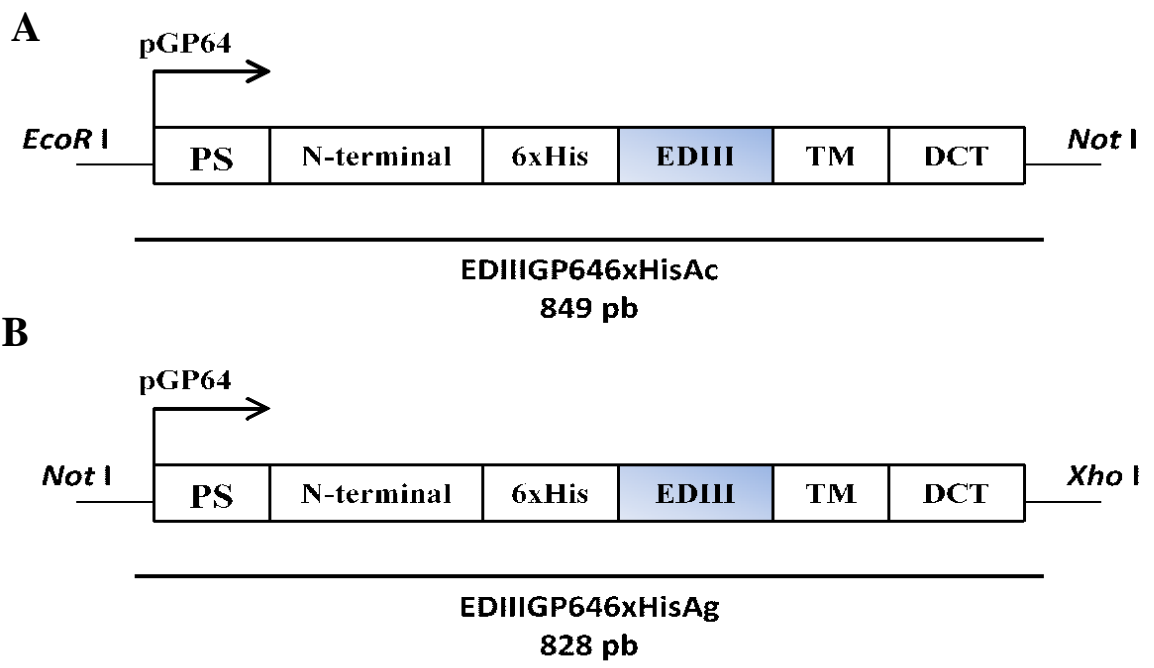

Figura 12. Esquema representativo dos cassetes de expressão do EDIII fusionado à proteína GP64 de baculovírus A) Cassete de expressão mostrando o domínio III da proteína de envelope do vírus da febre amarela (EDIII) fusionado com as regiões essenciais (Promotor - pGP64, peptídeo sinal de endereçamento - PS, domínio transmembrana - TM e domínio da cauda citoplasmática - DCT) do gene da proteína GP64 do baculovírus AcMNPV B) Cassete de expressão mostrando o domínio III da proteína de envelope do vírus da febre amarela (EDIII) fusionado com as regiões essenciais (Promotor - pGP64, peptídeo sinal de endereçamento - PS, domínio transmembrana - TM e domínio da cauda citoplasmática - DCT) do gene da proteína GP64 do baculovírus AgMNPV. 
Esses cassetes de expressão foram utilizados como molde para uma reação de PCR nas mesmas condições descritas no item 3.2, utilizando os mesmos primers. O resultado da PCR foi analisado por eletroforese em gel de agarose $0.8 \%$ de acordo com o protocolo descrito em Sambrook et al. (1989). Os fragmentos de DNA com os tamanhos esperados (849 bp - EDIIIGP646xHisAc ou 828 bp - EDIIIGP646xHisAg), correspondentes à amplificação dos cassetes de expressão, foram extraídos do gel, eluídos e purificados com o Kit GFX DNA and Gel Band Purification (GE) segundo instruções do fabricante. Os fragmentos eluídos foram clonados no vetor de clonagem pGEM $^{\circledR}-\mathrm{T}$ Easy Vector (Promega), seguindo as instruções do fabricante (dados não mostrados), gerando o plasmídeo pGEM GP64EDIII6xHisAc e pGEM GP64EDIII6xHisAg. A confirmação da obtenção dos plasmídeos foi feita por sequenciamento dos cassetes de expressão (Macrogen, Coréia do Sul).

Esses plasmídeos foram digeridos com as enzimas de restrição $\operatorname{Sph}$ I e $\operatorname{Sac}$ I (5 $\mu 1$ de DNA 30 ng/ $\mu 1,1 \mathrm{U}$ de cada enzima - Promega, $2 \mu \mathrm{l}$ BSA 10X, $2 \mu \mathrm{l}$ do tampão de reação 10X, e água "milli-Q" para um volume final de $20 \mu 1$ ). Da mesma forma e utilizando as mesmas enzimas, foi feita a digestão do plasmídeo pFASTBAC ACCI. A reação para digestão com as enzimas de restrição foi mantida a $37^{\circ} \mathrm{C}$ por $16 \mathrm{~h}$ (“overnight").

O plasmídeo pFASTBAC ACCI digerido foi utilizado em reação de ligação com os fragmentos digeridos EDIIIGP646xHisAc e EDIIIGP646xHisAg utilizando a enzima T4 DNA ligase (Promega) seguindo protocolo do fabricante. Foi realizada uma transformação por choque térmico (Sambrook et al., 1989). Para essa transformação foram utilizadas células $E$. coli $\mathrm{DH} 5 \alpha$ quimio-competentes comerciais. Os clones 
resultantes foram selecionados pela resistência aos antibióticos ampicilina e gentamicina. Posteriormente, foi feita uma purificação por lise alcalina, da mesma forma como descrito no item 3.2, e o DNA plasmidial foi analisado para confirmação da obtenção dos plasmídeos.

A confirmação da clonagem foi feita através de digestão com as enzimas de restrição $S p h$ I e $S a c$ I. Foram utilizados para essa reação de digestão $5 \mu 1$ de DNA plasmidial ( $30 \mathrm{ng} / \mu \mathrm{l}$ ), $2 \mu \mathrm{l}$ do tampão de reação 10X (Promega), $1 \mathrm{U}$ (unidade) da enzima Sph I (Promega), 1U (unidade) da enzima Sal I (Promega) e água “milli-Q” para

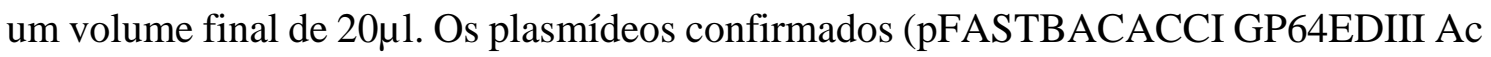
e pFASTBACACCI GP64EDIII Ag) foram então, sequenciados (Macrogen, Coréia do Sul).

3.4. Construção do vetor de transferência contendo o cassete gênico EDIII fusionado ao gene da poliedrina

O plasmídeo pFASTBACI-6xHis-AcPH foi utilizado para a construção do plasmídeo que contém o EDIII fusionado ao gene da poliedrina. Esse plasmídeo é similar ao plasmídeo $\mathrm{pFastBac}^{\mathrm{TM}}$ (Invitrogen), porém possui o promotor da poliedrina, o gene da poliedrina e uma cauda de seis histidinas, além de um sítio para enzima de restrição Nco I, dispostos como na seguinte figura: 


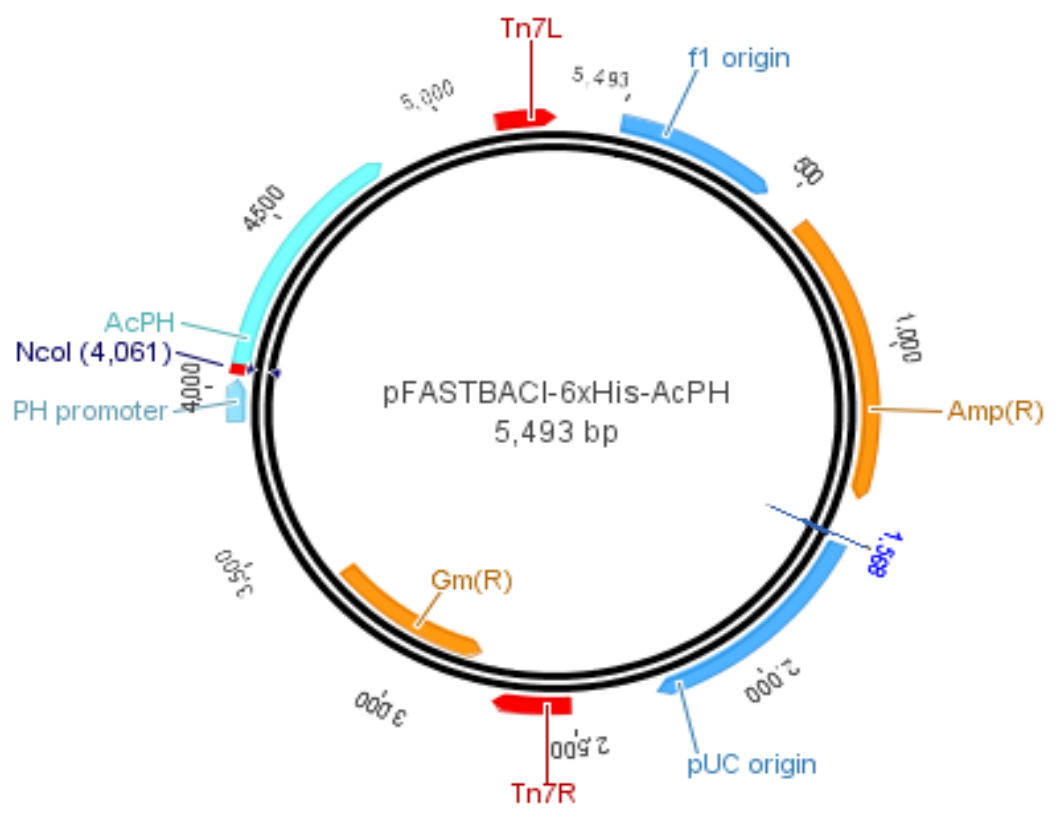

Figura 13. Esquema representativo do plasmídeo pFASTBACI-6xHis-AcPH. Na figura é possível ver o sítio de restrição da enzima Nco I, que foi utilizado para clonagem do EDIII, gene de resistência a Ampicilina (Amp), gene de resistência a Gentamicina (Gm), regiões de transposição Tn7R e Tn7L, origem de replicação pUC e origem de replicação f1 (esse plasmídeo possui duas origens de replicação para gerar um maior número de cópias). Esquema construído usando o programa Geneious (Biomatters Limited).

O plasmídeo pFASTBACI-6xHis-AcPH foi digerido com Nco I, foram utilizados para essa digestão aproximadamente $0.5 \mu \mathrm{g}$ de DNA plasmidial, $2 \mu 1$ do tampão de reação 10X (Promega), $2 \mu \mathrm{l}$ do tampão de BSA (albumina de soro bovino) (Promega), 1U (unidade) da enzima Nco I e água "milli-Q" para um volume final de $20 \mu 1$. Após a digestão, o vetor foi desfosforilado, utilizando os $20 \mu 1$ de DNA plasmidial digerido e 1 $\mu \mathrm{l}$ da enzima TSAP (Fosfatase alcalina termo-sensível - Promega), seguindo especificações do fabricante. A reação foi incubada 15 min a $37^{\circ} \mathrm{C}$ e 15 min a $70^{\circ} \mathrm{C}$. O fragmento EDIII foi retirado do plasmídeo pGEM GP64EDIII6xHisAc, que foi utilizado 
como molde para uma reação de PCR utilizando os primers YFEDIIIPOLFPCIIF e YFEDIIIPOLFPCIIR (Tabela 1). Esses primers amplificaram somente o fragmento EDIII e acrescentaram sítios para enzima de restrição $P c i$ I flanqueando o gene. As enzimas $P c i$ I e Nco I são isoesquizómeros. Para essa reação de PCR foram utilizados: 2,5 $\mu 1$ do tampão de reação 10X da enzima Taq DNA polimerase (Platinum ${ }^{\circledR}$ Taq DNA Polymerase Kit), 0,75 $\mu \mathrm{l}$ de $\mathrm{MgCl}_{2}$ (solução estoque $50 \mathrm{mM}$ ), $0,5 \mu \mathrm{l}$ da mistura dos quatro dNTPs (solução estoque $10 \mathrm{mM}), \quad 0,5 \mu 1$ do oligonucleotídeos YFED3POLFPCIIF e YFED3POLFPCIIR (solução estoque 10 $\mu \mathrm{M}$ ), $1 \mu 1$ do DNA - pGEM GP64ED36xHisAc ( 60 ng/ $\mu \mathrm{l}), 2 \mathrm{U}$ (unidades) da enzima Taq DNA polimerase (Platinum ${ }^{\circledR} T a q$ DNA Polymerase) e água "milli-Q" para um volume final de $25 \mu$ l. O seguinte programa foi utilizado: $94^{\circ} \mathrm{C} / 1 \mathrm{~min} \mathrm{~s}, 30$ ciclos de $94^{\circ} \mathrm{C} / 30 \mathrm{~s}, 55^{\circ} \mathrm{C} / 30 \mathrm{seg}, 72^{\circ} \mathrm{C} / 1 \mathrm{~min}$ e $72^{\circ} \mathrm{C} / 2 \mathrm{~min}$ para o término da extensão. O resultado da PCR foi analisado por eletroforese em gel de agarose $0.8 \%$ de acordo com o protocolo descrito em Sambrook et al. (1989). O fragmento de DNA com o tamanho esperado (310 bp), correspondente ao fragmento EDIII e os nucleotídeos adicionados pelos oligonucleotídeos, foi extraído do gel, eluído e purificado com o Kit GFX DNA and Gel Band Purification (GE) segundo instruções do fabricante. Após eluição esse fragmento de DNA foi utilizado em uma reação de digestão utilizando $0.5 \mu \mathrm{g}$ de fragmento de DNA, $2 \mu \mathrm{l}$ do tampão de reação 10X (Promega), $2 \mu \mathrm{l}$ do tampão de BSA (albumina de soro bovino) (Promega), 1U (unidade) da enzima Pci I e água "milli-Q" para um volume final de $20 \mu 1$. Após digestão o fragmento foi novamente foi extraído do gel, eluído e purificado com o Kit GFX DNA and Gel Band Purification (GE) segundo instruções do fabricante. 
O plasmídeo pFASTBACI-6xHis-AcPH digerido e desfosforilado foi utilizado em reação de ligação com o fragmento EDIII digerido com Pci I utilizando a enzima T4 DNA ligase (Promega) seguindo protocolo do fabricante. Foi realizada uma transformação por choque térmico (Sambrook et al., 1989). Para essa transformação foram utilizadas células $E$. coli $\mathrm{DH} 5 \alpha$ quimio-competentes comerciais. Os clones resultantes foram selecionados pela resistência aos antibióticos ampicilina e gentamicina. Posteriormente, foi feita uma purificação por lise alcalina como descrito no item 3.2. A confirmação da obtenção do plasmídeo pFASTBACI-6xHis-AcPH EDIII foi feita por sequenciamento dos cassetes de expressão (Macrogen, Coréia do Sul).

3.5. Construção e titulação dos vírus recombinantes contendo os fragmentos gênicos de interesse, fusionados aos genes da proteína do envelope (GP64) ou à proteína do corpo de oclusão (poliedrina) de baculovírus

Os plasmídeos gerados neste trabalho foram utilizados na construção do baculovírus recombinantes, utilizando o sistema Bac-to-Bac ${ }^{\circledR}$ (Invitrogen), seguindo instruções do fabricante. Resumidamente, neste sistema o gene de interesse é clonado em um plasmídeo doador $\mathrm{pFastBac}^{\mathrm{TM}}$, e o plasmídeo recombinante é transformado em células competentes DH10Bac ${ }^{\text {TM }}$ que contém um bacmídeo com um sítio de transposição mini-attTn7 e o plasmídeo auxiliar (pHelper). O sítio mini-Tn7 no plasmídeo pFastBac TM doador pode transpor para o sítio de destino mini-attTn7 no bacmídeo através de proteínas de transposição no plasmídeo auxiliar. Colônias contendo bacmídeos recombinante são identificados pelo rompimento do gene lacZ $\alpha$. O DNA dos bacmídeos recombinantes é extraido e este é, então, usado para transfecção em células de insetos. 
Neste trabalho, células $\mathrm{DH} 10 \mathrm{Bac}^{\mathrm{TM}}$ foram incubadas em placas de Petri a $37^{\circ} \mathrm{C}$ por $48 \mathrm{~h}$ contendo os seguintes antibióticos: tetraciclina $(10 \mu \mathrm{g} / \mathrm{ml})$, gentamicina $(7 \mu \mathrm{g} / \mathrm{ml})$ e Canamicina (50 $\mu \mathrm{g} / \mathrm{ml})$; e também os marcadores de seleção IPTG $(40 \mu \mathrm{g} / \mathrm{ml})$ e X-Gal $(100 \mu \mathrm{g} / \mathrm{ml})$. As colônias brancas foram coletadas e purificadas por lise alcalina (lise alcalina adaptada, onde só foram utilizadas as soluções I, II, III e precipitação com isopropanol, descritos no item 3.2. Para a construção dos baculovírus recombinantes, $1 \mu \mathrm{g}$ do DNA plasmidial da célula $\mathrm{DH} 10 \mathrm{Bac}^{\mathrm{TM}}$ contendo o bacmídeo recombinante, foi utilizado para transfectar células de inseto BTI-Tn5B1-4. Foram adicionados $250 \mu 1$ de meio de cultura TC-100 sem soro no DNA plasmidial (bacmídeo) em uma placa de 35 mm (TPP). A mesma diluição foi realizada com $10 \mu \mathrm{l}$ de lipossomos $\left(\right.$ Cellfectin ${ }^{\circledR}$, Invitrogen). Os dois sistemas foram misturados e incubados por 15 min à temperatura ambiente. O meio de cultura da placa de células foi, posteriormente, substituído por 500 $\mu 1$ da mistura DNA/lipossomos, possibilitando a cobertura da monocamada de células. Após 3h de incubação da placa, à temperatura ambiente, foram adicionados 1,5 $\mathrm{ml}$ de meio de cultura TC-100 contendo $10 \%$ de soro fetal bovino e as células incubadas a $27^{\circ} \mathrm{C}$ por sete dias. Posteriormente, o sobrenadante da placa de transfecção foi utilizado para a amplificação dos baculovírus recombinantes em uma nova placa de $100 \mathrm{~mm}$ (TPP) contendo células de inseto BTI-Tn5B1-4. Todos os vírus utilizados nesse trabalho foram titulados utilizando o método de diluição seriada em placa de 96 poços ("End-point dilution assay") descrito a seguir. Células Sf 9- ET foram semeadas na concentração de $1 \times 10^{4}$ células/ml em placas de 96 poços com meio TC-100 seguindo de incubação a $25^{\circ} \mathrm{C}$ por 2 hs para aderência das células na placa. As células aderidas foram infectadas com diluições seriadas (10 vezes) das amostras testadas e incubadas durante 3 dias a $25^{\circ} \mathrm{C}$. 
3 - 7 dias após a inoculação, os poços que possuíam células fluorescentes (positivas para expressão de eGFP) foram marcados e contados. O número de poços considerados positivos para a infecção em cada diluição, foi usado para calcular a titulação dos vírus utilizando o método descrito em Reed \& Muench, 1938.

3.6. Análise da expressão das proteínas recombinantes

\subsubsection{SDS-PAGE e Western-blot}

A confirmação da expressão das proteínas recombinantes foi feita analisando-se os extratos de células infectadas pelos vírus recombinantes em gel SDS-PAGE $12 \%$ (Laemmli, 1970), utilizando o aparato Mini Protean II (BioRad) e por Western blot, utilizando o anti-soro monoclonal anti-His (GE). Para este procedimento, foi utilizado o anticorpo monoclonal anti-His (GE), seguindo o protocolo abaixo:

Foram feitos dois géis, usando o aparato Mini Trans-Blot Cells de acordo com o protocolo de instruções do fabricante (Bio-Rad). Um dos géis foi corado e fixado em solução de $40 \%$ de metanol e $10 \%$ de ácido acético, $0,1 \%$ de corante Azul brilhante de Coomassie R-250 por 4h, com leve agitação. O outro foi utilizado para transferência das proteínas em uma membrana de nitrocelulose (Gibco BRL- Life Technologies) para o experimento de imunodetecção de proteínas (Western blot) como descrito abaixo.

Com o auxílio do aparato de transferência Trans-Blot SD Semi-Dry Transfer Cell (Bio-Rad), as proteínas foram transferidas para a membrana de nitrocelulose. As instruções foram seguidas de acordo com o protocolo do fabricante. Foi utilizado tampão 
de transferência Bjerrum and Schafer-Nielsen (48mM de Tris, 39mM de glicina, 20\% de metanol, pH 9,2). Após a transferência, a membrana foi bloqueada com solução de PBS $1 \mathrm{X}$ e $3 \%$ de leite em pó desnatado por $16 \mathrm{~h}$.

Depois, a membrana foi lavada 3 vezes com PBS Tween $(0,05 \%)$ por 5 min para retirar toda a solução de bloqueio. Adicionou-se uma solução de PBS/albumina bovina (BSA) $0,5 \%$ com o anticorpo primário monoclonal anti-His (GE Healthcare) produzido em camundongos por $1 \mathrm{~h}$. A seguir, a membrana foi lavada novamente 3 vezes em PBS Tween $(0,05 \%)$ por 5 min e incubada em PBS/BSA 0,5\% com o anticorpo secundário, anti-IgG de camundongo, conjugado à enzima fosfatase alcalina (Sigma) por mais $1 \mathrm{~h}$ sob agitação. Retirou-se a solução, membrana foi lavada 3 vezes com PBS Tween $(0,05 \%)$ e 1 vez com o tampão da enzima fosfatase alcalina por 5 min. A solução reveladora, NBT/BCIP (Invitrogen) foi adicionada servindo de substrato para a ação da fosfatase alcalina. O sistema foi mantido protegido da luz até a metabolização do substrato marcando, assim, a proteína de interesse devido à presença da enzima conjugada ao anticorpo secundário que se ligou ao anticorpo primário específico. Por fim, a reação foi interrompida com lavagens de água destilada evitando a marcação inespecífica.

A infecção com os baculovírus recombinantes e análise morfológica de células BTI-Tn5B1-4 foram analisadas utilizando microscopia de luz (Axiovert 100, Zeiss). 


\subsubsection{Microscopia confocal}

Células de inseto BTI-Tn5B1-4 foram cultivadas sobre lamínulas redondas de vidro e infectadas com os vírus recombinantes (m.o.i 10) que expressam as proteínas de interesse fusionadas à proteína GP64 de baculovírus. Após 48 hs de infecção, o sobrenadante foi retirado e as células foram fixadas com 1:1 Metanol/Acetona (fixação que permite a permeabilização das células) por 5 min a $-20^{\circ} \mathrm{C}$. Após a fixação, as células foram lavadas 3 vezes em PBS 1X e incubadas com $2 \%$ BSA durante 30 min a $37^{\circ} \mathrm{C}$. As células foram, então, incubadas com o anticorpo primário (Anti-His - GE, diluição 1:300) durante $1 \mathrm{~h} \mathrm{a} 37^{\circ} \mathrm{C}$. Após incubação com o anticorpo primário, as células foram lavadas 3 vezes com PBS $1 \mathrm{X}$ e incubadas $1 \mathrm{~h}$ a $37^{\circ} \mathrm{C}$ com anticorpo secundário (Anti-mouse IgG Alexa Fluor $^{\circledR}$ 488, diluição 1:1000 ou Anti-mouse IgG conjugado com FITC diluição 1:500). Após incubação com o anticorpo secundário as células foram lavadas 3 vezes com PBS 1X. Os controles negativos foram tratados da mesma forma. As lâminas foram analisadas usando microscópio confocal (Leica SP5).

\subsection{Imunização dos camundongos}

Os BVs contendo o EDIII fusionados à GP64 de AcMNPV e AgMNPV, e os BVs de AcMNPV e AgMNPV foram semipurificados (ultracentrifugação em colchão de sacarose $25 \%, 2$ h, $24.000 \mathrm{rpm}$ ) e utilizados na imunização de camundongos. Antes da imunização dos animais, foram retirados aproximadamente $50 \mu l$ de sangue de cada 
animal através de punção retro-orbital. Esse sangue foi centrifugado $5000 \mathrm{rpm}$ (Centrífuga 5418 - Eppendorf) por 5 min e armazenado a $-20^{\circ} \mathrm{C}$ para posterior análise. Foram utilizados 7 camundongos BALB/c fêmeas por grupo: Grupo de animais imunizados com $100 \mu \mathrm{l}$ de PBS 1x, imunizados com vacina comercial contra febre amarela 17DD (seguindo orientações do fabricante - Biomanguinhos/Fiocruz), imunizados com $1 \times 10^{8} \mathrm{pfu} / \mathrm{ml}$ de BVs semipurificados de AcMNPV, imunizados com $1 \times 10^{8} \mathrm{pfu} / \mathrm{ml}$ de BVs semipurificados de AgMNPV, imunizados com $1 \times 10^{8} \mathrm{pfu} / \mathrm{ml} \mathrm{de}$ BVs semipurificados que contendo EDIII fusionado à GP64 de AcMNPV e imunizados com $1 \times 10^{8} \mathrm{pfu} / \mathrm{ml}$ de BVs semipurificados contendo EDIII fusionado à GP64 de AgMNPV (Figura 14). A primeira imunização foi feita pela via subcutânea, utilizando os BVs mais adjuvante completo de Freund’s (Sigma). Após 15 dias da primeira imunização, os camundongos foram imunizados com as mesmas concentrações de BVs mais adjuvante incompleto de Freund's (Sigma), seguindo 15 dias da segunda imunização os camundongos foram imunizados com apenas os BVs semipurificados.

Os experimentos in vivo conduzidos neste trabalho foram desenvolvidos no laboratório de imunologia aplicada sob orientação da Professora Anamélia Lorenzetti Bocca, que possui aprovação do comitê de ética da UnB para as metodologias aqui utilizadas. O certificado de aprovação do comitê de ética encontra-se nos anexos da tese. 
A

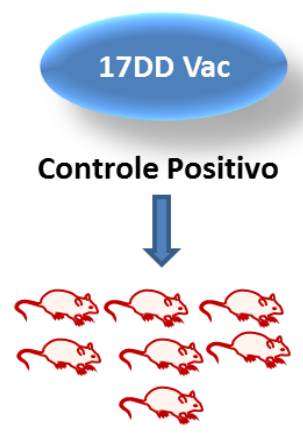

C

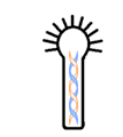

AcMNPV

Budded virus

$\rrbracket$

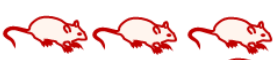

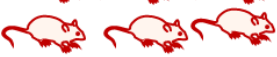

ngen
D

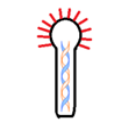

AgMNPV

Budded virus
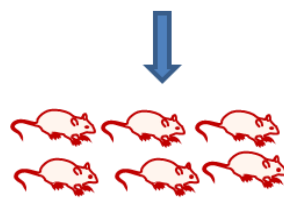

rm
B

\section{PBS}

Controle Negativo

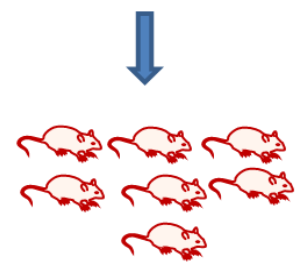

$\mathbf{E}$

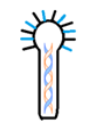

GP64ED3 Ac

Budded virus
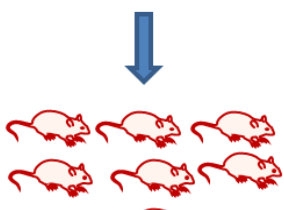

ngen

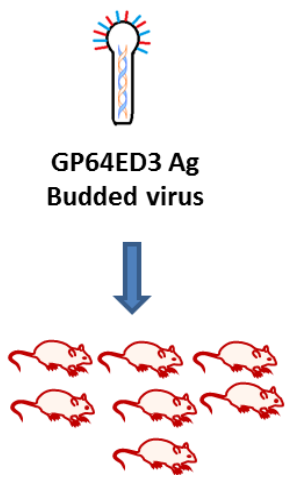

Figura 14. Sistema de imunização de camundongos com os baculovírus recombinantes. A) 7 camundongos fêmeas BALB/c foram imunizados com o vírus vacinal 17DD seguindo orientações do fabricante (Biomanguinhos/Fiocruz), essa imunização foi o controle positivo do experimento B) 7 camundongos fêmeas BALB/c foram imunizados com $100 \mu 1$ de PBS, essa imunização foi o controle negativo do experimento C) 7 camundongos fêmeas BALB/c foram imunizados com $1 \times 10^{8} \mathrm{pfu} / \mathrm{ml}$ de $\mathrm{BVs}$ semipurificados de AcMNPV D) 7 camundongos fêmeas BALB/c foram imunizados com 1x10 $0^{8} \mathrm{pfu} / \mathrm{ml}$ de BVs semipurificados de AgMNPV E) 7 camundongos fêmeas BALB/c foram imunizados com $1 \times 10^{8}$ pfu/ml de BVs semipurificados que expressam EDIII fusionado à GP64 de AcMNPV F) 7 camundongos fêmeas BALB/c foram imunizados com $1 \times 10^{8} \mathrm{pfu} / \mathrm{ml}$ de BVs semipurificados que expressam EDIII fusionado à GP64 de AgMNPV. Todas as imunizações foram feitas subcutaneamente. 


\subsection{Teste de proliferação de linfócitos}

Linfócitos foram isolados a partir do baço de animais imunizados e não imunizados com os vírus recombinantes vGP64 EDIII Ac, vGP64 EDIII Ag e também com os baculovírus AcMNPV e AgMNPV que serão os controles negativos para a expressão de EDIII. Os baços foram macerados e o líquido resultante foi coletado através de filtração em “Cell Strainer". Esse líquido filtrado foi centrifugado a 300 x $g$ por 10 min a $4^{\circ} \mathrm{C}$ e o precipitado foi incubado com solução de lise (Cloreto de amônio 0,16 M pH 4,75 e Tris 0,17 M pH 7,5). A lise foi interrompida por adição de meio RPMI simples, seguindo de nova centrifugação $300 \times \mathrm{x}$ por $10 \mathrm{~min}$ a $4^{\circ} \mathrm{C}$. O precipitado foi lavado 3 vezes com RPMI simples seguindo as mesas condições. Após lavagem o precipitado foi ressuspendido em $1 \mathrm{ml}$ de meio RPMI simples e as células foram contadas e através de coloração com Azul de Tripan $0.4 \%$ avaliadas quanto à viabilidade. As células foram, então, separadas em duas alíquotas, uma que foi usada como controle negativo para fluorescência e outra para marcação com 5mM de CFSE (Carboxifluoresceína succinimidyl éster). Um total de $10^{7}$ células viáveis foram marcadas com CFSE, após marcação foi preparado uma suspensão de $3 \times 10^{6}$ células/ml e a partir dessa suspensão plaqueados $100 \mu 1 /$ poço (placa de 96 poços) + $100 \mu 1$ de estímulo específico. Os estímulos foram: Meio RPMI (Controle negativo), Concanavalina $4 \mu \mathrm{g} / \mathrm{ml}$ (ConA), LPS (Lipopolissacarídeo), BVs purificados de AcMNPV, AgMNPV, vGP64EDIII Ac e vGP64EDIII Ag em concentração de $1 \times 10^{9} \mathrm{pfu} / \mathrm{ml}$. 


\section{Resultados}

4.1. Confirmação da obtenção dos plasmídeos pFASTBAC ACCI GP64 Ac, pFASTBAC ACCI GP64 Ag, pFASTBAC ACCI GP64 EDIII Ac e pFASTBAC ACCI GP64 EDIII Ag

Os cassetes GP646xHisAc e GP646xHisAg, foram amplificados por PCR e clonados no plasmídeo pFASTBAC ACCI nos sítios das enzimas de restrição Sac I e Sph I, gerando os plasmídeos pFASTBAC ACCI GP64 Ac e pFASTBAC ACCI GP64 Ag (Figura 15).
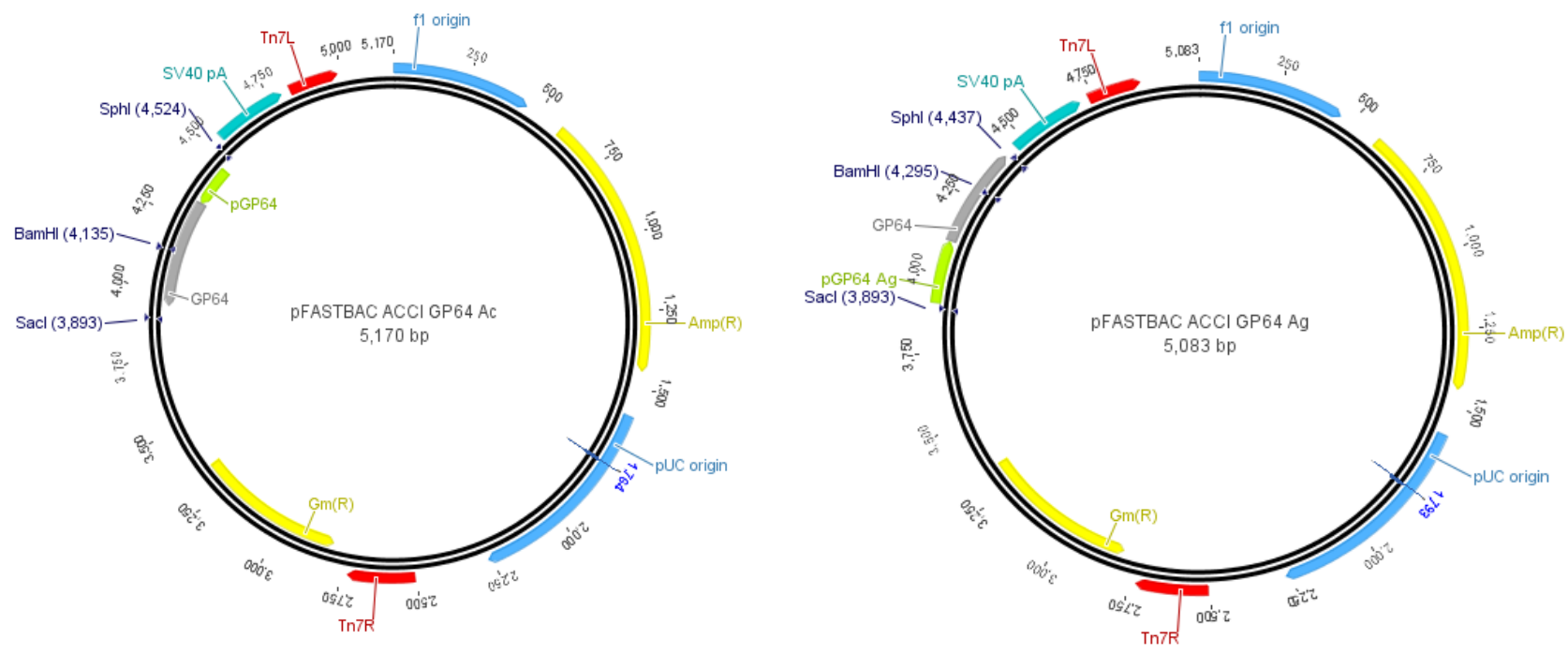

Figura 15. Mapa dos plasmídeos pFASTBAC ACCI GP64 Ac e pFASTBAC ACCI GP64 Ag. Na figura é possível ver os sítios de restrição das enzimas $\operatorname{Sph}$ I $e$ Sac I, que foram utilizados para clonagem dos cassetes de expressão, os cassetes de expressão que consistem em promotor GP64 (pGP64), sítio de clonagem de genes heterólogos BamH I e gene gp64 (composto de PS, pequena região N-terminal, TM e CTD) gene de resistência a Ampicilina (Amp), gene de resistência a Gentamicina $(\mathrm{Gm})$, regiões de transposição Tn7R e Tn7L, sinal de poliadenilação SV40 pA, origem de replicação pUC e origem de replicação f1 (esse plasmídeo possui duas origens de replicação para gerar um maior número de cópias). Mapa construído usando o programa Geneious (Biomatters Limited). 
Bem como os cassetes ED3IIIGP646xHisAc e ED3IIIGP646xHisAg foram amplificados por PCR e clonados no plasmídeo pFASTBAC ACCI nos sítios das enzimas de restrição $S a c$ I e $S p h$ I, gerando os plasmídeos pFASTBAC ACCI GP64 Ac e pFASTBAC ACCI GP64 Ag (Figura 16).
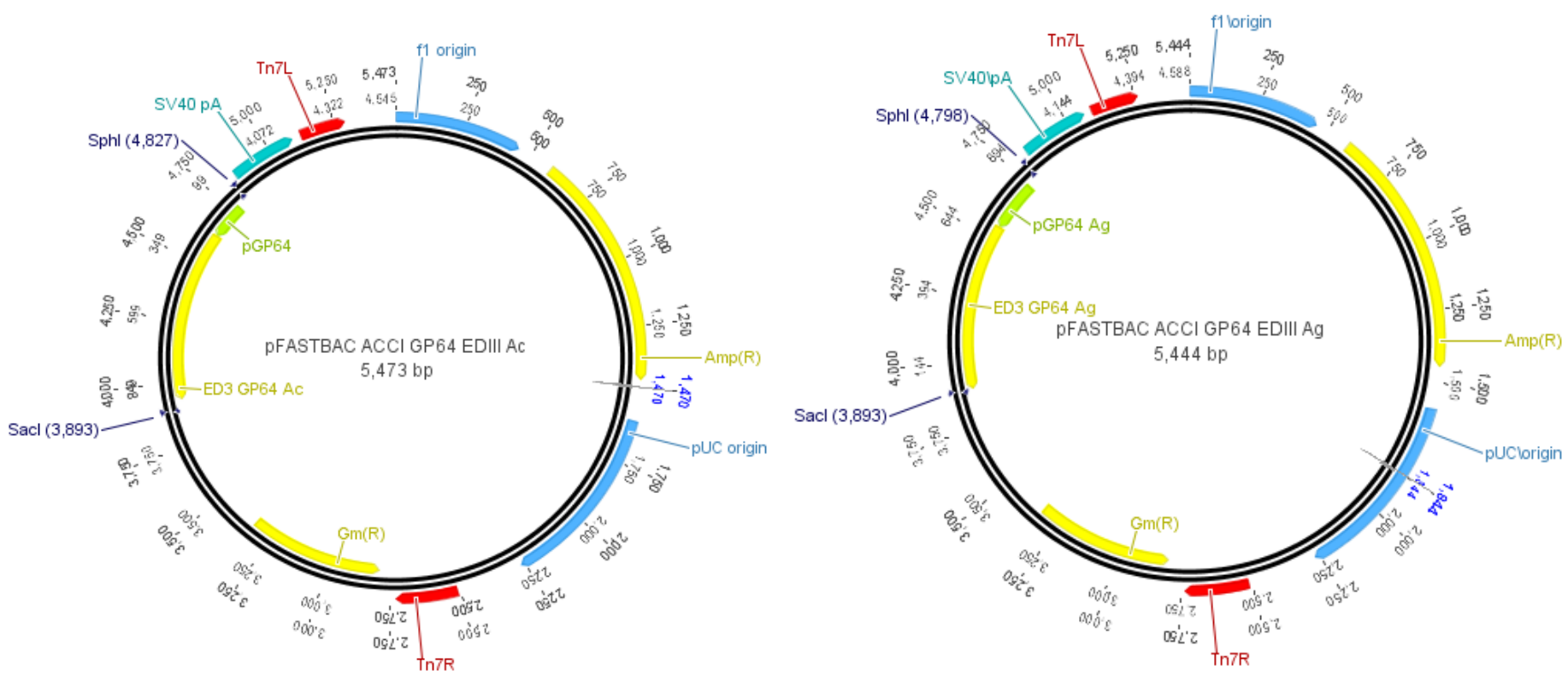

Figura 16. Mapa dos plasmídeos pFASTBAC ACCI GP64 EDIII Ac e pFASTBAC ACCI GP64 EDIII Ag. Na figura é possível ver o sítio de restrição das enzimas $\operatorname{Sph}$ I $e$ Sac I, que foi utilizado para clonagem dos cassetes de expressão, os cassetes de expressão que consistem em promotor GP64 (pGP64), gene gp6 4(composto de PS, pequena região N-terminal, TM e CTD) + EDIII, gene de resistência a Ampicilina (Amp), gene de resistência a Gentamicina $(\mathrm{Gm})$, regiões de transposição Tn7R e Tn7L, sinal de poliadenilação SV40 pA, origem de replicação pUC e origem de replicação f1 (esse plasmídeo possui duas origens de replicação para gerar um maior número de cópias). Mapa construído usando o programa Geneious (Biomatters Limited). 
A clonagem foi confirmada por digestão do DNA dos plasmídeos recombinantes com as enzimas de restrição $S p h$ I e $S a c$ I. A digestão com as enzimas de restrição $S a c$ I e Sph I liberou um fragmento de 631 bp para o plasmídeo pFASTBAC ACCI GP64 Ac, um fragmento de 544 bp pFASTBAC ACCI GP64 Ag, um fragmento de 934 bp pFASTBAC ACCI GP64 EDIII Ac e um fragmento de 905 bp pFASTBAC ACCI GP64 EDIII Ag confirmando, assim, a correta inserção dos cassetes no plasmídeo pFASTBAC ACCI. A digestão com as enzimas de restrição foi analisada em gel de agarose $0,8 \%$ (Figura 17).

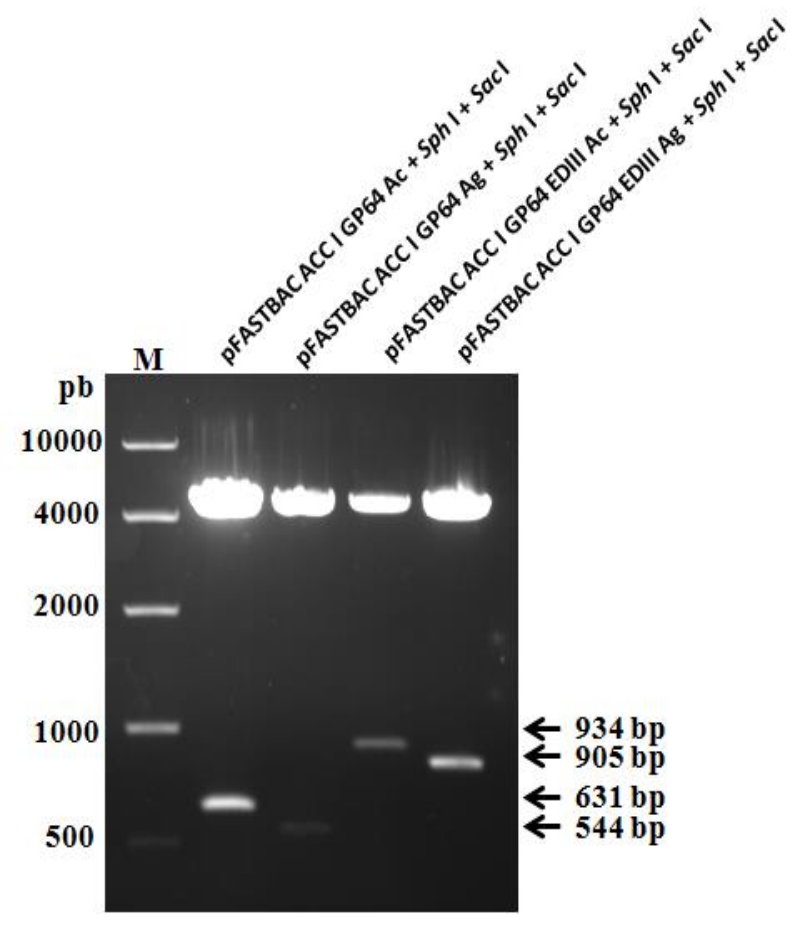

Figura 17. Confirmação da clonagem dos plasmídeos pFASTBAC ACCI GP64 Ac, pFASTBAC ACCI GP64 Ag, pFASTBAC ACCI GP64 EDIII Ac e pFASTBAC ACCI GP64EDIII Ag por digestão com as enzimas de restrição Sph I e Sac I. Gel de agarose a 0,8\% mostrando DNA dos plasmídeos digeridos com as enzimas de restrição Sph I e Sac I liberando fragmentos de 631, 544, 934, 905 pares de base, que correspondem aos cassetes GP646xHisAc, GP646xHisAg, ED3IIIGP646xHisAc e ED3IIIGP646xHisAg, respectivamente. 
4.2. Confirmação da obtenção do plasmídeo pFASTBACI-6xHis-AcPH EDIII

O fragmento gênico correspondente ao EDIII foi clonado no plasmídeo pFASTBACI-6xHis-AcPH na região da enzima de restrição Nco I, gerando o plasmídeo pFASTBACI-6xHis-AcPH EDIII (Figura 18).

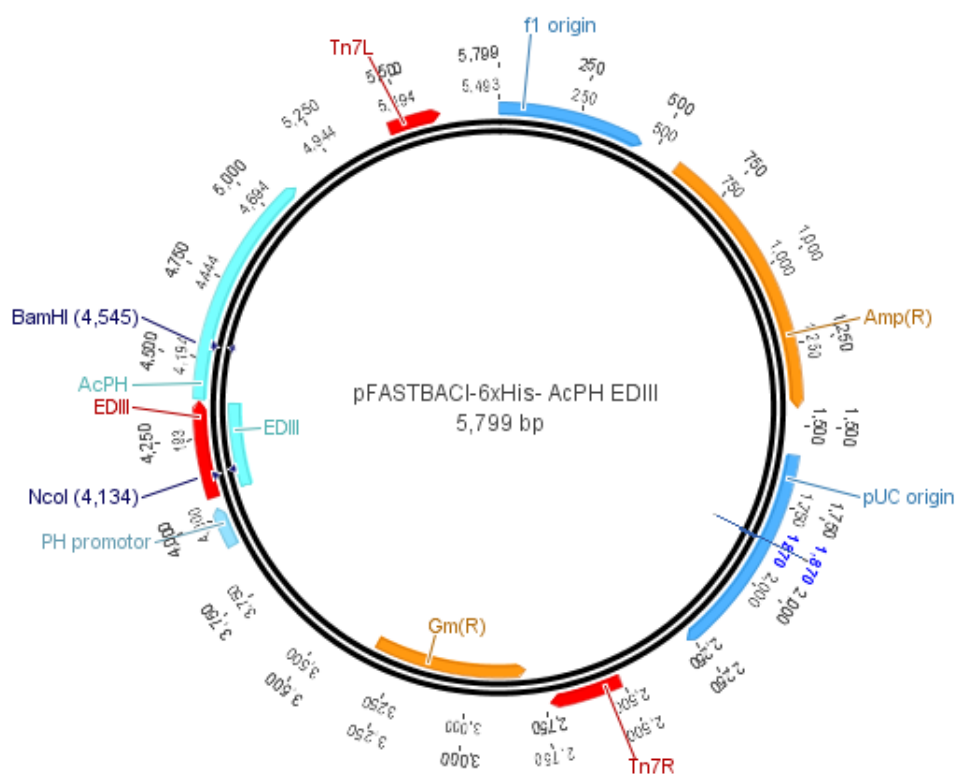

Figura 18. Mapa do plasmídeo pFASTBACI-6xHis-AcPH EDIII. Na figura é possível ver os sítios de restrição das enzimas de restrição BamH I e Nco I, que foram utilizados para confirmação da obtenção do plasmídeo, gene de resistência a Ampicilina (Amp), gene de resistência a Gentamicina (Gm), regiões de transposição Tn7R e Tn7L, sinal de poliadenilação SV40 pA, origem de replicação pUC e origem de replicação f1 (esse plasmídeo possui duas origens de replicação para gerar um maior número de cópias). Mapa construído usando o programa Geneious (Biomatters Limited).

A clonagem foi confirmada por digestão do DNA do plasmídeo recombinante com as enzimas de restrição BamH I e Nco I. A digestão com as enzimas de restrição BamH I e Nco I liberou um fragmento de 411 bp confirmando, assim, a correta inserção dos cassetes no plasmídeo pFASTBACI-6xHis-AcPH. A digestão com as enzimas de restrição foi analisada em gel de agarose $0.8 \%$ (Figura 19). 


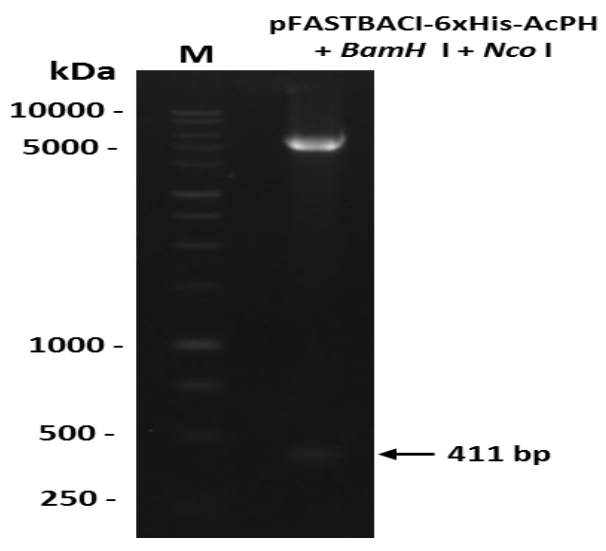

Figura 19. Confirmação da clonagem do plasmídeo pFASTBACI-6xHis-AcPH EDIII por digestão com as enzimas de restrição BamH I e Nco I. Gel de agarose a 0,8\% mostrando DNA do plasmídeo que foi digerido com as enzimas de restrição BamH I e Nco I liberando um fragmento de 411 pares de base, confirmando a obtenção do plasmídeo recombinante.

4.3. Construção dos baculovírus recombinantes e confirmação da expressão das proteínas

\subsubsection{EDIII fusionado à poliedrina de AcMNPV}

Todos os plasmídeos recombinantes foram utilizados para transposição sítio específica, através do sistema Bac-to-Bac® Baculovirus Expression System (Invitrogen). Vírus recombinantes que expressam proteínas de febre amarela fusionadas à GP64 (proteína de envelope de baculovírus) e vírus recombinante que expressa EDIII fusionado à poliedrina (principal constituinte dos corpos de oclusão, também denominados poliedros) foram construídos, visando a comparação da melhor estratégia para expressão dessas proteínas. O DNA dos bacmídeos recombinantes foram utilizados para transfecção em células BTI-Tn5B1-4 e sete dias pós-transfecção, o sobrenadante foi coletado e usado 
para infectar células BTI-Tn5B1-4. No caso do vírus contendo o cassete EDIII fusionado à poliedrina, houve mudança morfológica das células infectadas (5 dias p.i) com o vírus recombinante vEDIIIPol (células ficaram arredondadas e núcleo hipertrofiado), essas mudanças são características de infecção viral, porém, observa-se formação de massa protéica no citoplasma de células infectadas com esse vírus recombinante (vírus recombinante que expressa EDIII fusionando à poliedrina de AcMNPV), diferentemente do observado nas células infectadas com o vírus selvagem, onde o fenótipo do corpo de oclusão possui a forma esperada de um poliedro (Figura 20).

Mock

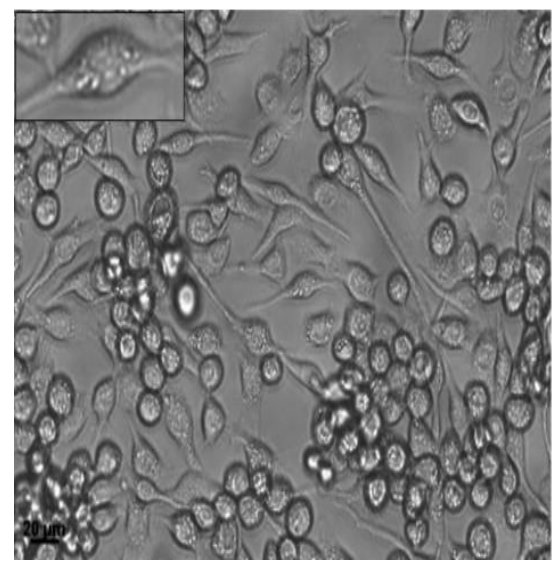

AcMNPV

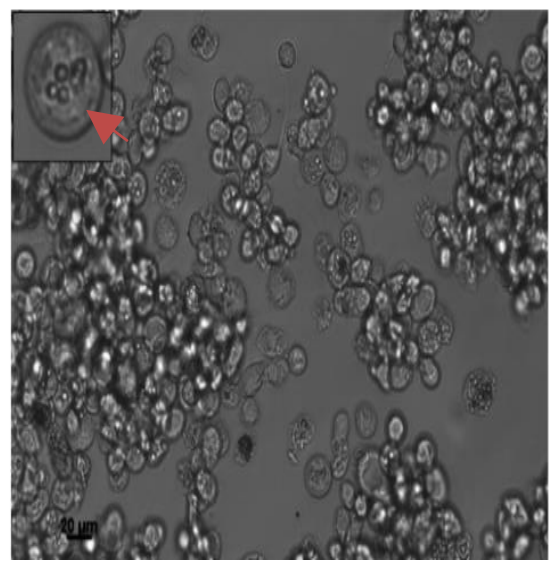

VEDIIIPOI

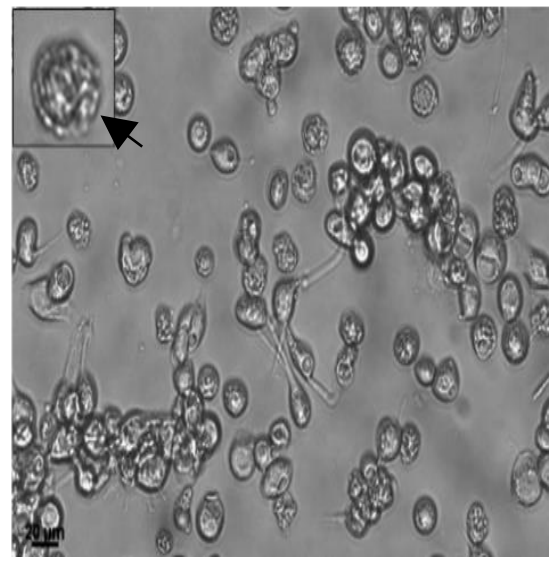

Figura 20. Efeito citopático da infecção de células BTI-Tn5B1-4 com diferentes baculovírus a 72 h p.i. Em destaque uma célula não infectada (Mock), uma célula infectada com baculovírus selvagem AcMNPV, apresentando poliedros típicos (seta vermelha) e uma célula infectada com o baculovírus recombinante vEDIIIPol, mostrando a não formação de poliedros típicos e apresentando uma massa protéica proveniente da fusão de EDIII com a poliedrina (seta preta). As células foram analisadas utilizando microscópio óptico

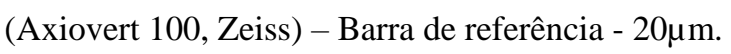


O Western blot do extrato total de células infectadas com vEDIIIPol confirmou a expressão de uma proteína de aproximadamente $41 \mathrm{kDa}$, compatível com o tamanho da proteína fusionada (Figura 21).

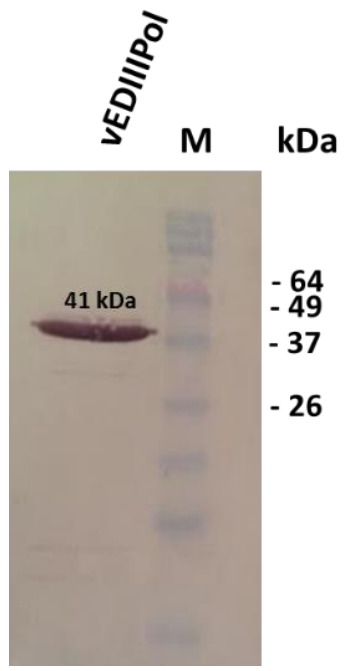

Figura 21. Análise do perfil da proteína recombinante EDIII fusionada à poliedrina de AcMNPV. A confirmação da expressão da proteína recombinante foi feita através de Western blot utilizando o extrato total de células infectadas com o vírus recombinante vEDIIIPol $72 \mathrm{~h}$ p.i. e anti-soro monoclonal anti-His, o tamanho esperado da proteína $(41 \mathrm{kDa})$ foi confirmado corretamente no extrato celular.

A inserção de genes de interesse na sequência gênica da poliedrina pode, algumas vezes, causar problemas na montagem correta do poliedro como ocorrido neste trabalho. Porém, essa diferença morfológica não interfere na alta expressão da proteína recombinante de interesse. Testes in vivo (infecção de lagartas) estão em andamento para verificar se a montagem desses poliedros recombinantes pode ser facilitada dentro do inseto. A purificação dessa proteína recombinante será feita utilizando cromatografia de afinidade e após a purificação, será realizada a imunização de camundongos do tipo 
$\mathrm{BABL} / \mathrm{c}$ e análises imunológicas, bem como seu potencial para uma vacina recombinante, serão analisados.

\subsubsection{EDIII fusionado à GP64 de AcMNPV e AgMNPV}

Análise das células infectadas com os vírus recombinantes que expressam EDIII na superfície de BVs por microscopia óptica foram feitas, mas nenhuma mudança morfológica diferente da esperada para infecção viral (células grandes, arredondadas e núcleo hipertrofiado) foi encontrada. Após infecção de células BTI-Tn5B1-4 com os vírus recombinantes (48 h p.i.), a confirmação da expressão das proteínas heterólogas foi feita através de Western blot. Pode-se observar a marcação de uma banda de menor massa molecular abaixo da proteína recombinante ED3IIIAg. Essa banda deve-se, provavelmente, a uma degradação da proteína de interesse, processo comum durante a manipulação de amostras protéicas. Deve-se ressaltar que essa banda inespecífica é mais evidente na amostra de extrato celular, que possui uma grande quantidade de protease celular (Figura 22). 


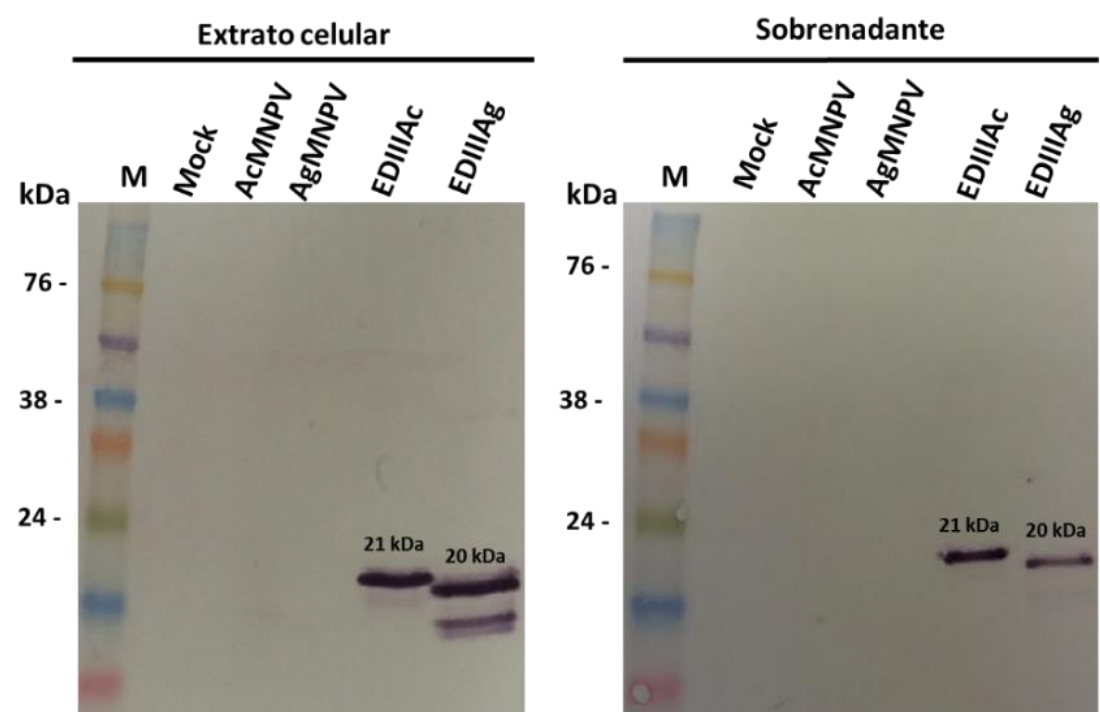

Figura 22. Análise do perfil da proteína recombinante EDIII fusionada à GP64. A confirmação da expressão das proteínas recombinantes foi feita através de Western blot. Neste experimento foi utilizado o extrato total de células infectadas com os vírus recombinantes e selvagens (48 h p.i.), também foi feito o mesmo experimento utilizando partículas BV de baculovírus semi-purificadas por ultracentrifugação em colchão de sacarose 25\%. Para o Western blot foi utilizado anti-soro monoclonal anti-His. O tamanho esperado das proteínas foi confirmado tanto no extrato celular, quanto nos BVs semipurificados (presentes no sobrenadante).

A expressão das proteínas EDIII fusionadas à GP64 de AcMNPV e AgMNPV na superfície de células infectadas (BTI-Tn5B1-4) foi também analisada através de microscopia confocal e mostrou a expressão das proteínas recombinantes na superfície da célula, o que confirma a correta expressão de EDIII (Figura 23). 


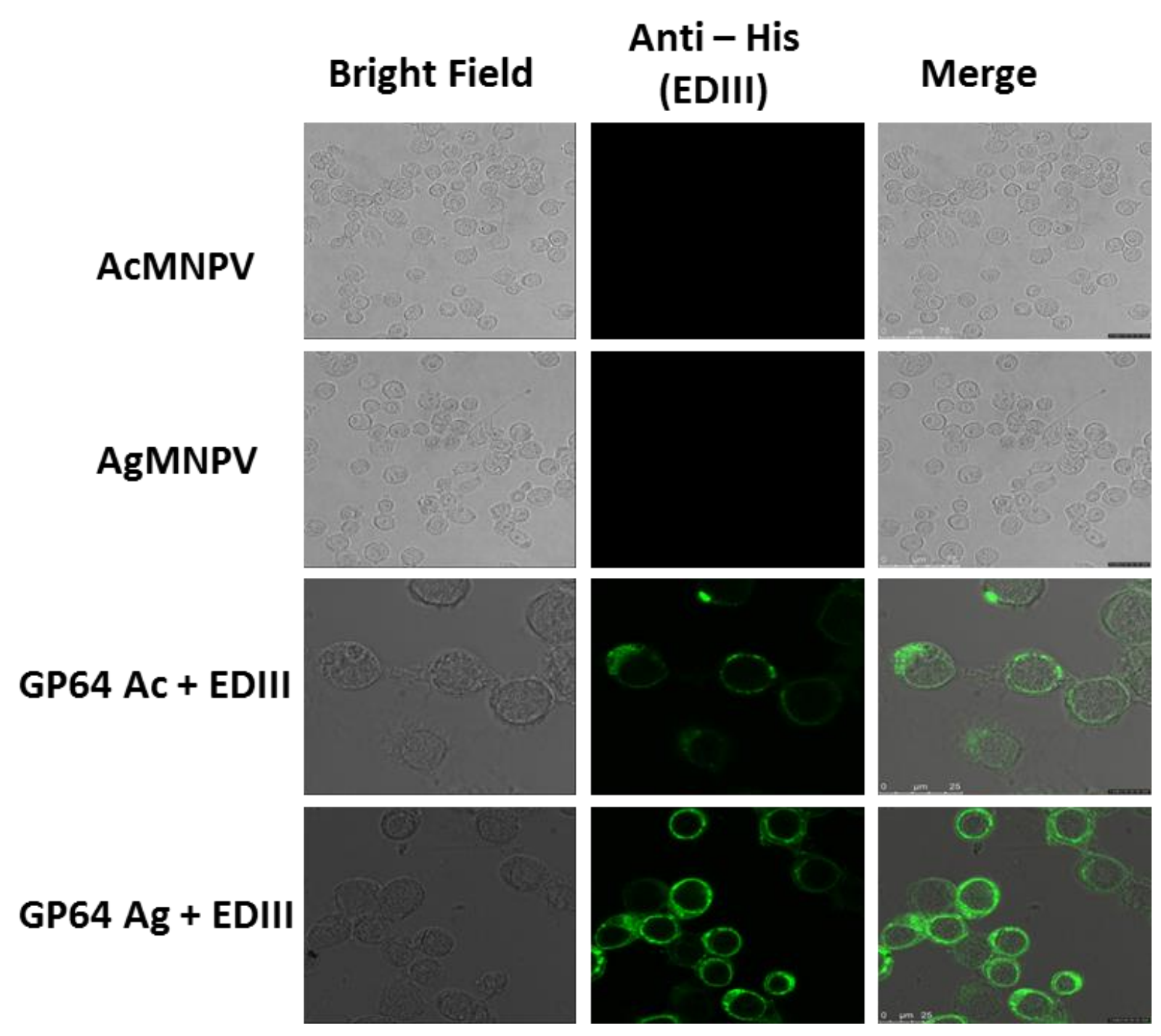

Figura 23. Análise do perfil da proteína recombinante EDIII fusionada à GP64 na superfície de células de inseto. Células BTI-Tn5B1-4 foram infectadas com os vírus recombinantes vGP64EDIII Ac e vGP64EDIII Ag usando m.o.i 5, $48 \mathrm{~h} \mathrm{p.} \mathrm{i.} \mathrm{as} \mathrm{células} \mathrm{foram} \mathrm{incubadas} \mathrm{com} \mathrm{anticorpo} \mathrm{primário} \mathrm{anti-His} \mathrm{produzido} \mathrm{em}$ camundongo e depois com anticorpo secundário anti- IgG de camundongo conjugado a FITC, após marcação as células foram analisadas em microscópio confocal para visualização da proteína recombinante na superfície de células infectadas. As amostras foram analisadas em microscópio confocal (Leica TCS SP5) - Barra de referência - $25 \mu \mathrm{m}$. 
Após a confirmação da correta expressão das proteínas heterólogas, foi realizado a imunização de camundongos BABL/c subcutaneamente com $100 \mu \mathrm{l}\left(1\right.$ x $\left.10^{8} \mathrm{pfu} / \mathrm{ml}\right) \mathrm{de}$ BVs semi-purificados de AcMNPV, AgMNPV, vGP64EDIII Ac e vGP64EDIII Ag. Após a imunização, os baços dos camundongos imunizados com os diferentes tratamentos foram coletados e os linfócitos isolados. Os linfócitos foram então estimulados com diferentes tratamentos e sua capacidade de proliferação avaliada (Figura 24).

$\mathbf{A}$

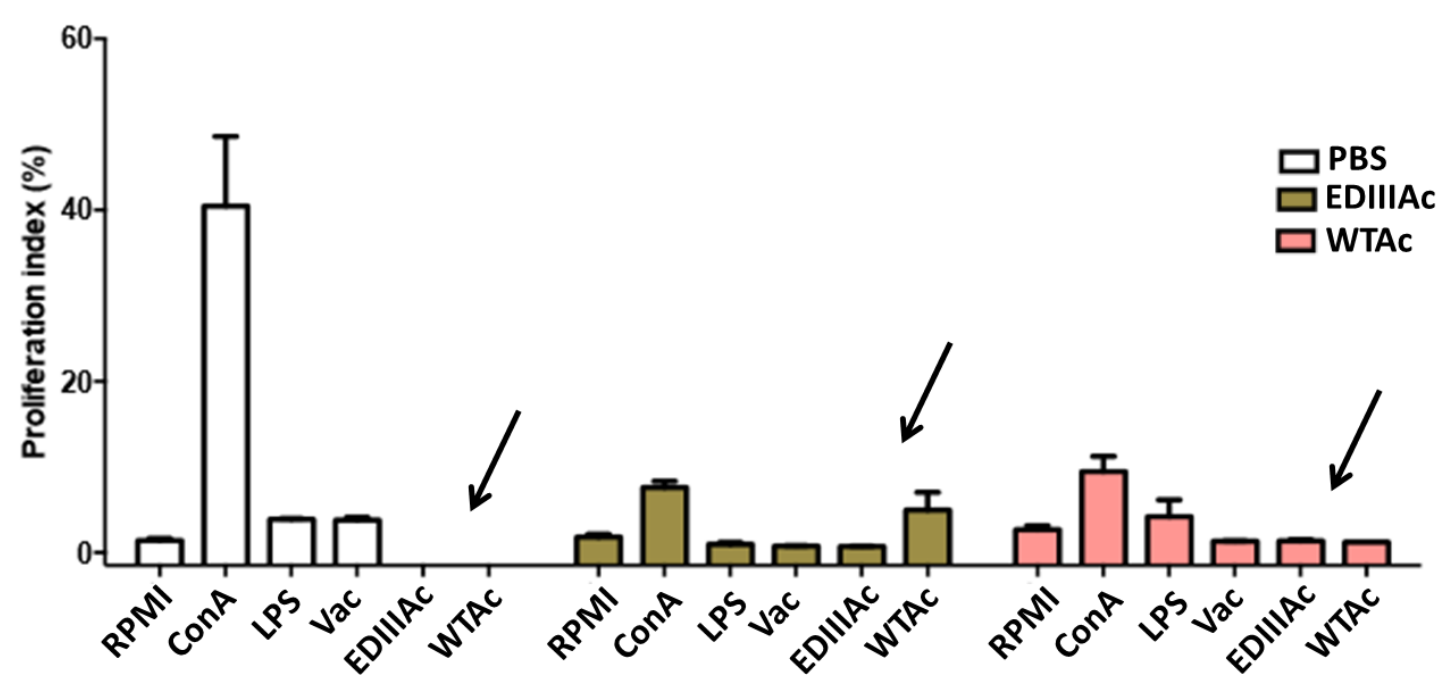


B

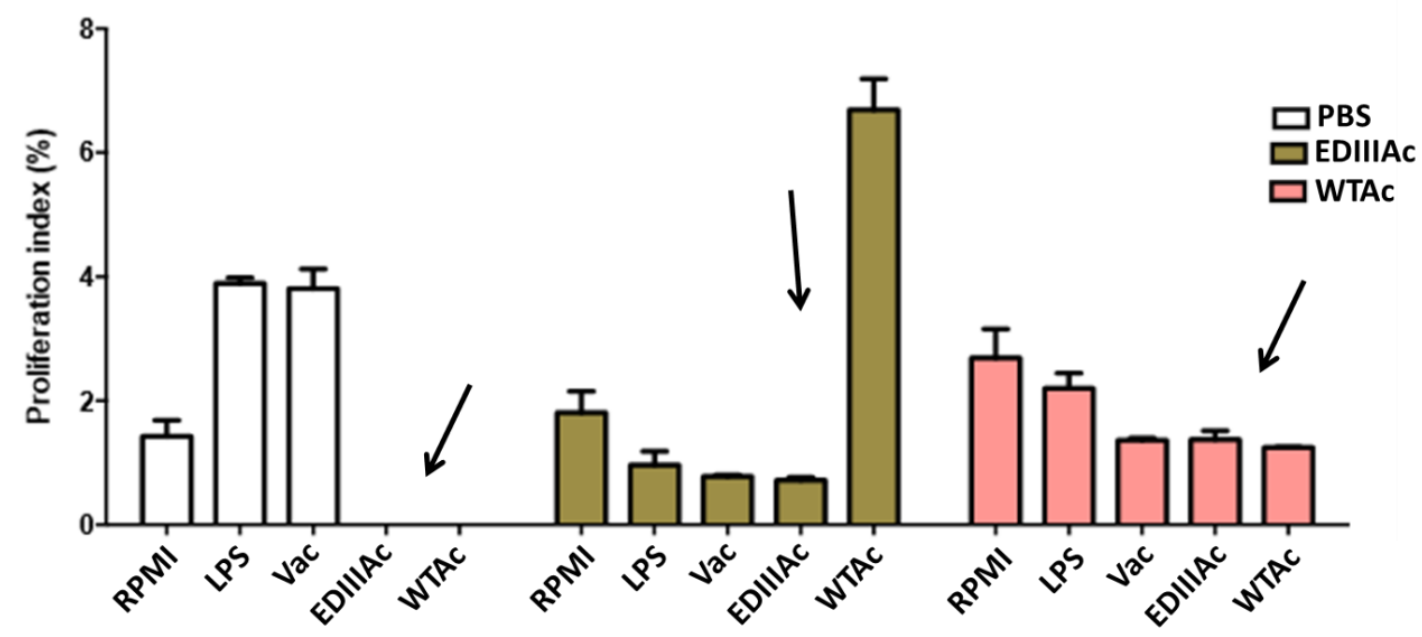

C

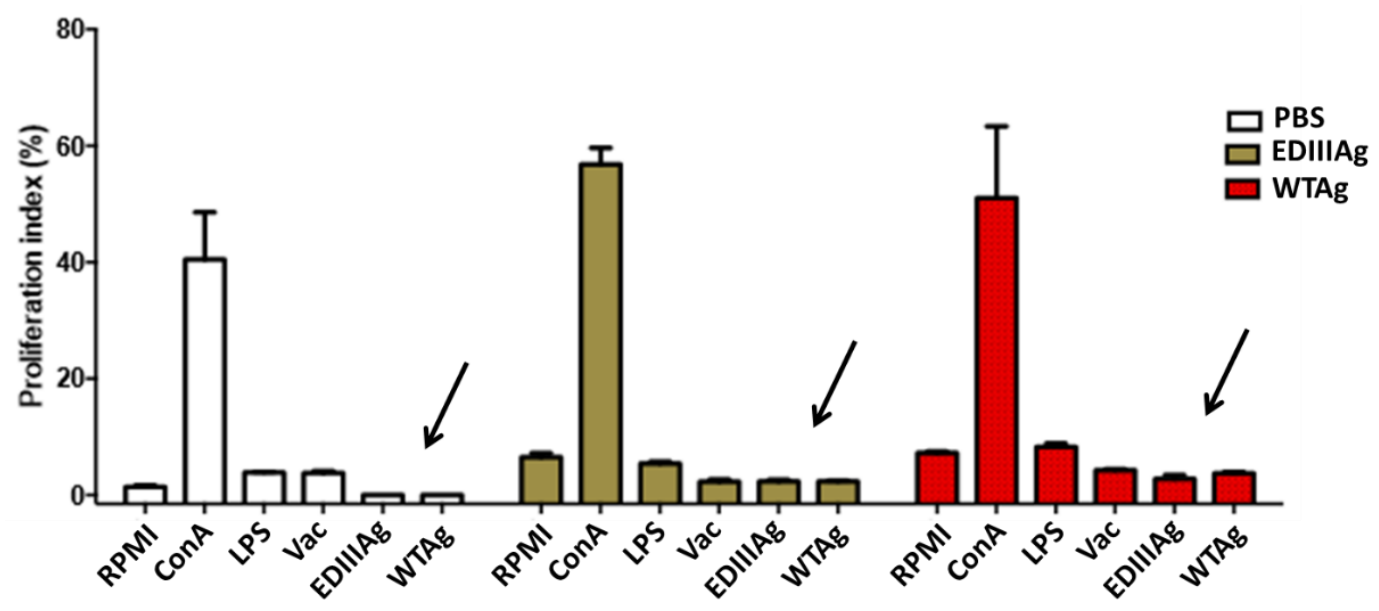


D

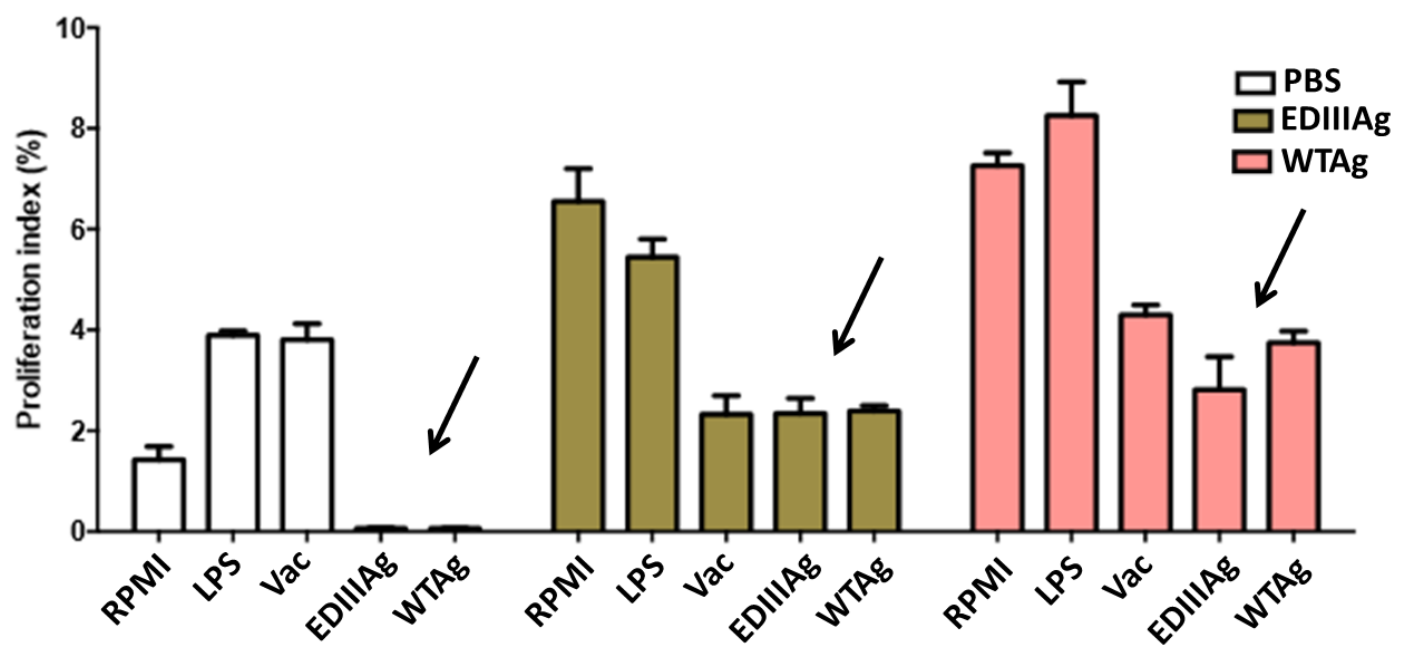

Figura 24. Análise da proliferação de linfócitos testados com diferentes estímulos. Camundongos do tipo BALB/C foram imunizados subcutaneamente com PBS, vacina comercial contra FA (17DD), BVs semipurificados de AcMNPV (WTAc), AgMNPV (WTAg), vGP64EDIII Ac (EDIIIAc) e vGP64EDIII Ag (EDIIIAg) $\left(1 \times 10^{8} \mathrm{pfu} / \mathrm{ml}\right)$ e testados quanto à sua proliferação quando estimulados com RPMI, LPS, Vacina (Vac), LPS (estímulo positivo para linfócitos do tipo B) ConA (estímulo positivo para linfócitos do tipo T), BVs semi-purificados de vGP64EDIII Ac e vGP64EDIII Ag A) Linfócitos de camundongos imunizados com PBS, BVs semi-purificados de AcMNPV e vGP64EDIII Ac e sua capacidade de proliferação com os diferentes estímulos B) Linfócitos de camundongos imunizados com PBS, BVs semipurificados de AcMNPV e vGP64EDIII Ac e sua capacidade de proliferação quando comparados somente ao controle positivo para proliferação de linfócitos do tipo B - LPS C) Linfócitos de camundongos imunizados com PBS, BVs semi-purificados de AgMNPV e vGP64EDIII Ag e sua capacidade de proliferação com os diferentes estímulos D) Linfócitos de camundongos imunizados com PBS, BVs semipurificados de AgMNPV e vGP64EDIII Ag e sua capacidade de proliferação quando comparados somente ao controle positivo para proliferação de linfócitos do tipo B - LPS. 
O teste de proliferação de linfócitos, indica a capacidade de linfócitos de se proliferarem ao reconhecer algum estímulo previamente apresentado, isso significa que esses linfócitos podem reconhecer especificamente algum antígeno e responder imunologicamente a ele. São usados dois controles positivos nesse experimento, a ConA (Concanavalina A) que é uma lectina que atua como mitógeno e estimula a proliferação de células T e o LPS (Lipopolissacarídeo) que é um estimulador da proliferação de linfócito do tipo B.

Os linfócitos extraídos de animais imunizados com os diferentes tratamentos foram testados quanto a sua capacidade de proliferação a diferentes estímulos (Figura 24). Os estímulos foram BVs semi-purificados do sobrenadante de células infectadas com AcMNPV (indicado na figura como WTAc), AgMNPV (indicado na figura como WTAg), vGP64EDIII Ac (EDIII Ac) e, vGP64EDIII Ag (EDIII Ag). Na figura 24 A, observa-se a baixa capacidade de proliferação dos linfócitos (setas) quando estimulados com WTAc e EDIII Ac quando comparamos com o controle ConA, isso significa que provavelmente não há proliferação de linfócitos do tipo T. Porém quando comparamos os mesmos resultados em um gráfico que mostra somente o controle positivo para proliferação de linfócitos do tipo B (LPS), observa-se que a proliferação de linfócitos com os estímulos WTAc e EDIII Ac (setas), assemelhando-se aos linfócitos que proliferam na presença do estímulo vacinal (Figura $24 \mathrm{~B}$ ). O mesmo resultado foi observado quando avaliado o estímulo da proliferação de linfócitos na presença dos estímulos BVs de WTAg e EDIII Ag (setas), indicando que provavelmente linfócitos do tipo B estão se proliferando e dando um indicativo da via de ativação imunológica desses animais pósimunização com as partículas recombinantes (Figura 24 C e D). 


\section{Discussão}

Como vetores de expressão de genes heterólogos, os baculovírus são capazes de expressar diversas proteínas em células de insetos. Essas proteínas são ativas biologicamente e imunologicamente similares às naturais, sendo expressas em altos níveis. Além de seguro, esse sistema é vantajoso por ser um ambiente eucariótico, permitindo a expressão de proteínas complexas e a coexpressão de dois ou mais genes (O’Reilly et al., 1992; Ribeiro et al., 2015). Uma das maneiras de expressão de proteínas heterólogas usando o sistema baculovírus e célula de inseto é a fusão da proteína de interesse com partes da glicoproteína principal do fenótipo BV dos baculovírus, a proteína GP64. Nessa estratégia, a proteína fica disponível na superfície do vírus (Oker-Blom et al., 2003).

Neste estudo, foi desenvolvido uma técnica nova para a produção de baculovírus recombinantes para a expressão de proteínas do vírus da febre amarela na superfície da partícula baculoviral. Como descrito acima, o método mais conhecido para isso é a fusão de proteínas heterólogas com as regiões essenciais da proteína GP64 de AcMNPV. Porém, neste trabalho, também foi utilizado a proteína GP64 de AgMNPV. Além de comparar os dois métodos, essa nova abordagem tem como objetivo, evitar recombinações do gene gp64 selvagem com o gene gp64 recombinante, pois não há deleção do gene gp64 natural do baculovírus AcMNPV, usado como base para produção de vírus recombinantes. A sequência da proteína GP64 de AgMNPV é muito semelhante com a de AcMNPV, exceto pela região TM e DCT (Li \& Blissard, 2009), o que pode diminuir a chance de recombinação entre essas duas proteínas. 
Então, o domínio III da proteína de envelope (EDIII) de FA foi fusionado a GP64 de AgMNPV e AcMNPV. O EDIII está envolvido na ligação ao receptor e contém epítopos críticos para a neutralização específica do vírus (epítopos de neutralização que distinguem cada flavivirus) (Chu et al., 2005). Por essas características, o EDIII têm sido estudado como possível candidato a uma vacina de subunidade para diversos flavivirus. Anticorpos induzidos pela imunização de camundongos com EDIII do vírus da encefalite japonesa (JEV), foram capazes de proteger camundongos em um ensaio de desafio letal (Fan et al., 2013). Camundongos imunizados com EDIII proveniente da proteína de envelope do vírus da Dengue (DENV) foram capazes de induzir a produção de anticorpos neutralizantes e somente duas imunizações com a proteína recombinante foram necessárias para gerar memória contra infecções por DENV, isso sem a presença de adjuvante (Coconi-Linares et al., 2013).

Apesar desses e outros estudos mostrarem a eficácia de EDIII como candidato para a produção de vacinas de subunidades, este trabalho é o primeiro a testar EDIII de FA como antígeno vacinal. A correta expressão de EDIII FA fusionado a GP64 de AcMNPV e AgMNPV foi confirmada por Western blot tanto no extrato total de células infectadas com os vírus recombinantes, quanto em partículas de baculovírus semipurificadas (BVs). Células de inseto infectadas com os vírus recombinantes contendo EDIII/GP64 foram, também, analisadas em microscópio confocal. Nesse experimento foi possível ver que EDIII/GP64 de ambos os baculovírus testados, foi corretamente encaminhado para a superfície celular e uma vez na superfície de células infectadas será corretamente incorporado a partículas BVs que brotam através da membrana plasmática. 
Após esses experimentos, testes in vivo foram e estão sendo conduzidos, a fim de determinar a imunogenicidade de EDIII quando fusionada a proteína de envelope do envelope de baculovírus e seu potencial como vacina de subunidade contra febre amarela.

No estudo de Xu et al., 2011, a proteína de envelope (E) do vírus da encefalite japonesa - JEV - foi fusionado a GP64 de AcMNPV e os baculovírus recombinantes usados na imunização de camundongos em condições semelhantes àquelas conduzidas neste trabalho. Após imunização de camundongos, pode-se notar uma resposta imune celular no teste de proliferação de linfócitos, isso quer dizer que linfócitos do tipo T proliferaram mais quando estimulados com E de JEV. Diferentemente do analisado neste trabalho, aqui a resposta foi mediada, aparentemente, por células B. Em 1978, Edward Jenner foi pioneiro na produção de uma vacina contra o vírus da varíola, e esta induzia uma robusta imunidade humoral, em outras palavras, imunidade mediada por células B de memória (Theves, 1997). Apesar da resposta imune celular também ser presente, a resposta humoral é mais forte e a responsável pela proteção duradoura (Kennedy et al., 2009). Sabe-se que BVs purificados derivados de AcMNPV (somente com a presença de um gene repórter luficerase para análise da imunização desses animais) induzem resposta imune mediada por célula e a produção de anticorpos BV - específicos (Luo et al., 2013). Levando em consideração esse e outros estudos anteriores, esperava-se que inicialmente, fosse desencadeada a resposta imune celular em resposta a imunização utilizando BVs recombinantes. Portanto, após o teste de proliferação de linfócitos, novas análises serão conduzidas para avaliar detalhadamente a via de ativação do sistema imune a partir da imunização desses camundongos com os BVs recombinantes que expressam o domínio III da proteína de envelope do vírus da febre amarela. Para isso, análise da produção de 
citocinas e avaliação da produção de anticorpos neutralizantes estão em andamento, e também novas técnicas de imunização e uso de diferentes adjuvantes ainda serão testados. Vale ressaltar que a resposta imunológica obtida até agora, mostra que essa estratégia tem grande potencial no desenvolvimento de uma vacina eficaz na indução de uma resposta protetiva contra o vírus da FA.

Uma outra estratégia para expressão e utilização de EDIII está sendo desenvolvida. A fusão de EDIII com o gene da poliedrina de baculovírus. O plasmídeo (pFASTBACI-6xHis-AcPH) possui o gene da poliedrina e um sítio de clonagem que permite a fusão do gene heterólogo com esse gene e foi utilizado neste trabalho para a expressão do fragmento EDIII fusionado ao gene da poliedrina de AcMNPV. Je et al. (2003) e Chang et al. (2003) demonstraram que é possível a produção de baculovírus recombinantes que possuem uma ou mais proteínas heterólogas incorporadas nos corpos de oclusão, mantendo o fenótipo dos vírus oclusos. Neste trabalho, apesar da correta fusão de EDIII com a poliedrina de AcMNPV, confirmada por Western blot, não foi possível ver a formação de poliedros (corpo de oclusão) em células infectadas com o vírus recombinante vEDIIIPol. Porém foi observado a formação de uma massa protéica no citoplasma de células infectadas. Larvas de insetos estão sendo infectadas com vEDIIIPol e a análise morfológica desses poliedros produzidos in vivo será realizada. Testes para a purificação de EDIIIPol serão feitos usando gradiente de sacarose e também por cromatografia de afinidade, já que essa proteína possui uma cauda de histidina.

Apesar do cultivo de bactérias ser mais econômico que o de células de inseto, muitas vezes o custo do processo de purificação das proteínas expressas em bactérias é alto, tornando a expressão em células de inseto vantajosa (Montor \& Sogayar, 2003). 
Mesmo com a disponibilidade de diversos sistemas para expressão de proteínas, as bactérias permanecem como a escolha da maioria dos sistemas de expressão, porém, devido à falta de maquinaria para modificações pós-traducionais em bactérias, a produção de proteínas recombinantes eucarióticas representa um desafio imenso, que invariavelmente leva à produção de proteínas biologicamente inativas neste hospedeiro (Sahdev et al., 2008). O sistema de expressão de baculovírus em células de inseto fornece um ambiente adequado para a síntese de proteínas eucarióticas oferecendo condições para que ocorra o dobramento adequado da estrutura da proteína, formação de pontes dissulfídicas, oligomerização e modificações pós-traducionais similares às produzidas em células de mamíferos (O’Reilly et al., 1992).

Este estudo visa a expressão do domínio III da proteína E do vírus de febre amarela usando duas técnicas bem diferentes, mas ambas a partir do sistema baculovírus de expressão. As duas técnicas possuem vantagens e desvantagens, por isso faz-se necessário a avaliação da melhor e mais vantajosa técnica para a expressão de proteínas imunogênicas derivadas de flavivirus. O “display” de proteínas heterólogas na superfície de baculovírus é um sistema vantajoso na praticidade, pois a própria partícula baculovirual atua como antígeno vacinal. Já a fusão de proteínas com a poliedrina é vantajosa na purificação que depende somente de um gradiente de sacarose. Além disso, a produção do "poliedro" recombinante é muito alta, já que a poliedrina está sob o comando de um promotor forte e seus níveis de expressão são elevados nas fases tardias de infecção. 
Novas técnicas para a expressão de proteínas heterólogas com fins biotecnológicos estão sendo desenvolvidas e a análise dessas técnicas será de grande valia na escolha do melhor método para diferentes proteínas de interesse biofarmacológico.

\section{Perspectivas}

- Análise da produção de citocinas para avaliar a via de ativação do sistema imune a partir da imunização de animais com BVs contendo EDIII na sua superfície;

- Análise da melhor forma de imunização dos animais com os BVs recombinantes: Intraperitoneal, intramuscular ou subcutâneo;

- Análise do uso de diferentes adjuvantes (Hidróxido de alumínio ou Freund`s);

- Clonagem da proteína de E inteira do vírus da febre amarela nos vetores para “display" na superfície de BVs e produção dos baculovírus recombinantes;

- Imunização de camundongos com esses novos vírus;

- Análise do seu potencial na ativação do sistema imune (teste de proliferação de linfócitos, análise das citocinas e quantificação dos anticorpos neutralizantes);

- Produção in vivo de poliedros recombinantes EDIIIpol;

- Tentativa da purificação do EDIII fusionado com poliedrina por gradiente de sacarose ou por cromatografia de afinidade;

- Imunização de camundongos com o EDIIIPol purificado e avaliação do seu potencial como imunógeno. 
Capítulo II - Produção de VLPs de HIV-1 utilizando células de inseto "GP64 free"

\section{Introdução}

1. 1. HIV - Vírus da imunodeficiência humana ("Human Immunodeficiency Virus")

Desde que os primeiros casos reconhecidos como a Síndrome da Imunodeficiência Adquirida (AIDS) foram identificados no início de 1980 e a descoberta do vírus da imunodeficiência humana (HIV), esta doença tornou-se uma das principais causas de mortalidade e morbidade em todo o mundo. No ano de 2013, as estimativas globais mostraram que cerca de 35 milhões de pessoas vivem com a infecção pelo HIV (Rubens et al., 2015). Só em 2014, 1.2 milhões de pessoas morreram de AIDS no mundo (UNAIDS 2015, Fact sheet 2014 statistics).

O Departamento de DST, Aids e Hepatites Virais estima aproximadamente 734 mil pessoas vivendo com HIV/Aids no Brasil no ano de 2014, correspondendo a uma prevalência de 0,4\%. Desde o início da epidemia de Aids (1980) até dezembro de 2013, foram identificados 278.306 óbitos tendo como causa básica a Aids, sendo a maioria na região Sudeste (61,8\%), seguida do Sul (17,3\%), Nordeste (11,9\%), Centro-Oeste $(5,0 \%)$ e Norte (4,0\%). Em 2013, a distribuição proporcional dos 12.431 óbitos foi de 44,0\% no Sudeste, $21,2 \%$ no Sul, $20,0 \%$ no Nordeste, $9,1 \%$ no Norte e 5,8\% no Centro-Oeste (Ministério da Saúde, 2015).

O HIV é um retrovírus transmitido através do contato com o sangue, esperma ou secreção vaginal de pessoas infectadas, e também através de transmissão vertical (mãe 
para o filho) tanto no parto, quanto por amamentação (Mugo et al., 2011). O vírus infecta células do sistema imune como os linfócitos $\mathrm{T} \mathrm{CD}^{+}$macrófagos e células dendríticas (Liu et al., 2004). Assim, a infecção por HIV compromete o sistema imune do hospedeiro, o deixando suscetível a diversas infecções.

Existem dois tipos de HIV que podem causar AIDS, o HIV-1 e o HIV-2. Os dois tipos de HIV possuem os mesmos mecanismos de replicação, modos de transmissão e consequências clínicas, porém a progressão para imunodeficiência ocorre mais lentamente nas pessoas infectadas com HIV-2. Além disso, existe uma diferença na distribuição geográfica entre os dois tipos de HIV. HIV-1 ocorre no mundo todo e o HIV2 se concentra principalmente na África Ocidental e alguns países na Europa (Nyamweya et al., 2013).

\section{2. Tratamento e prevenção}

O tratamento se baseia na terapia com anti-retrovirais, estes aumentavam a expectativa de vida dos portadores do HIV em cinco anos. Mas com o desenvolvimento de novos medicamentos retrovirais, a expectativa passou para algo em torno de 20-50 anos. Deve-se lembrar que o tratamento com medicamentos anti-retrovirais deve ser contínuo, o uso intermitente desses medicamentos pode diminuir ou até anular sua eficácia. Na ausência de tratamento, a morte ocorre geralmente no prazo de um ano (Buchbinder et al., 1994; Schneider et al., 2005). Hoje mais de que 25 fármacos que bloqueiam a replicação do HIV em diferentes etapas do ciclo de vida do vírus estão licenciados. 
Embora haja um número de intervenções eficazes de prevenção e métodos de tratamento como a profilaxia pré-exposição e tratamento anti-retroviral, os pesquisadores sempre foram zelosos sobre vacinas contra o HIV. Apesar desses esforços, há poucos estudos que têm demonstrado resultados bem sucedidos (Rubens et al., 2015). Essa dificuldade no desenvolvimento de uma vacina eficaz se deve pela diversidade genética do HIV, a incerteza sobre o que constitui a imunidade protetora contra o vírus e a dificuldade no desenvolvimento de antígenos altamente imunogênicos (Maartens et al., 2014).

1.3. HIV- Taxonomia, estrutura e ciclo de infecção

O HIV pertence à família Retroviridae, subfamília Orthoretrovirinae, gênero Lentivirus. Pertencem a família Retroviridae muitos vírus amplamente estudados, incluindo o vírus da imunodeficiência humana 1 (HIV-1, Lentivirus), vírus linfotrópico de células T humanas -1 (HTLV-1, Deltaretrovirus), vírus do sarcoma de Rous (RSV, Alpharetrovirus), vírus da leucemia murina (MLV, Gammaretrovirus) e vírus de macaco Mason-Pfizer (MPMV, Betaretrovius) (Zhang et al.,2015).

No caso do HIV-1, o genoma de RNA tem aproximadamente 9,7 kb e após ser transcrito em uma fita de DNA que codifica nove ORFs; além dos genes gag, pol, e env que são típicos de todos os retrovírus, existem dois genes reguladores (tat e rev) e quatro acessórios (nef, vif, vpr e vpu). Estas regiões codificadoras de proteínas são flanqueadas por regiões não codantes 5 'e 3' de LTR que são necessárias para a transcrição reversa, a integração, e alguns passos da expressão gênica (Suzuki \& Suzuki, 2011) (Figura 25). 

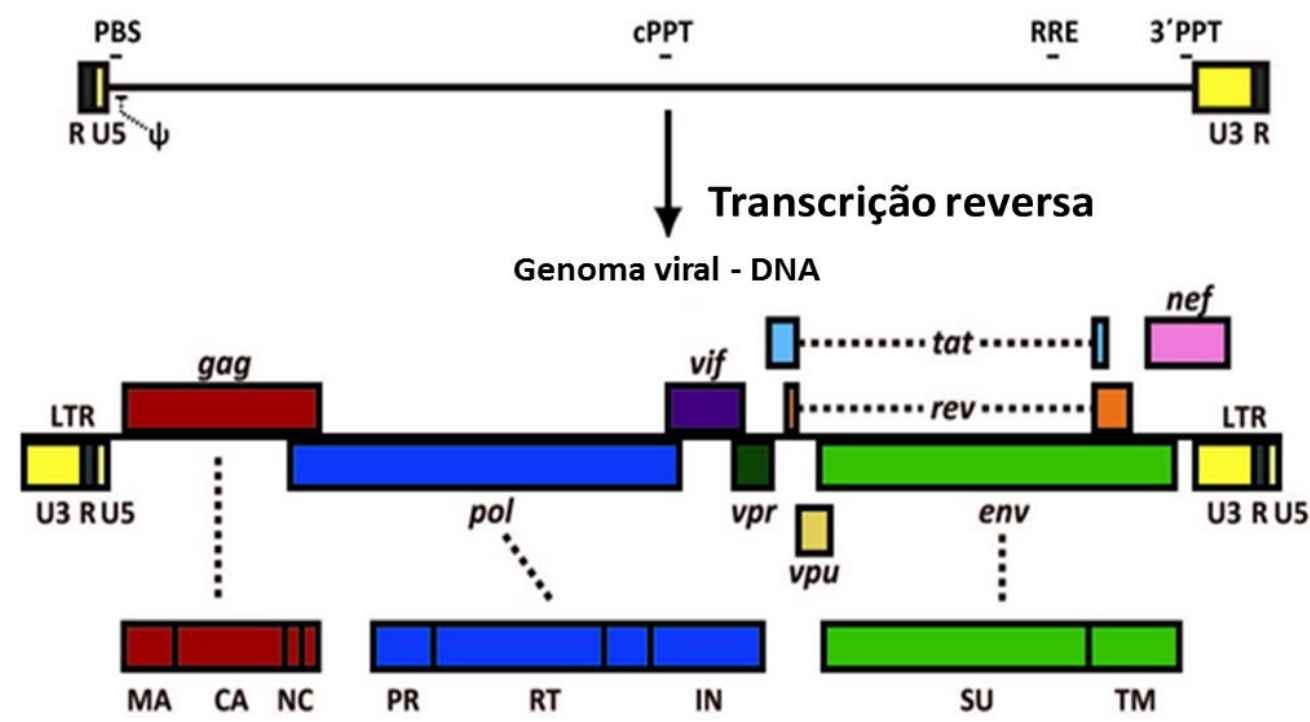

Figura 25. Esquema ilustrativo do genoma do vírus HIV. RNA de aproximadamente 9,7 kb e região PBS (“Primer binding sites"), sinal de encapsidação $\Psi$, duas regiões PPT (“Polypurine tract") uma na região 3' e uma central - cPPT - local de síntese da fita positiva de DNA - e RRE ("rev response element"). O mRNA sofre transcrição reversa gerando uma fita de DNA positiva que codifica 9 ORFs. Na figura é possível ver as duas regiões LTR 5 'e 3', genes gag, pol, env (estruturais), vif, vpr, vpu, nef (acessórios), tat e rev (regulatórios). O gene gag codifica uma poliproteína que depois é processada para gerar as proteínas MA (Matriz), CA (Capsídeo) e NC (Nucleocapsídeo); bem como o gene pol que gera as proteínas PR (Protease), RT (Transcriptase reversa) e IN (Integrase); e o gene env que codifica após processamento SU (Proteína de superfície) e TM (Proteína transmenbrana). Fonte: Adaptado de Suzuki \& Suzuki, 2011.

O ciclo de infecção de HIV pode ser resumido em 13 passos: (1) O ciclo se inicia quando a glicoproteína de envelope de superfície gp120 interage e se liga ao receptor CD4 e co-receptor CCR5 ou CXCR4 presentes na superfície da célula alvo (2) ocorre fusão de membrana induzida pela glicoproteína de envelope gp41, a membrana do vírion e a membrana plasmática da célula hospedeira se fundem liberando o nucleocapsídeo 
viral no interior da célula (3) ocorre um processo conhecido como "uncoating", conhecido como a desmontagem do capsídeo viral e é um passo essencial durante o ciclo de replicação (4) Durante o "uncoating” ocorre a transcrição do RNA viral em DNA através da enzima RT (5) o complexo denominado "complexo de pré-integração" é transportado pela membrana nuclear (6) no núcleo, integração do DNA viral no cromossomo da célula é catalizado pela IN (7) o DNA integrado (provírus) serve como molde para a síntese de RNA viral, que é transportado para o citoplasma (8) as proteínas Env são sintetizadas no RE e transportadas para a membrana através da via secretora celular (9) os precursores das poliproteínas Gag e Gal-Pol são sintetizados e encaminhados para a membrana plasmática (10) a montagem de Gag na membrana celular, induz o brotamento da partícula (11) durante o brotamento as glicoproteínas Env são incorporadas nas partículas (12) o brotamento é completo e as partículas liberadas no meio extracelular (13) durante o brotamento ou imediatamente após ele, a proteína viral PR cliva os precursores das poliproteínas Gag e Gag-Pol em proteínas maduras Gag e Pol. Esse processo desencadeia a condensação do núcleo gerando partículas maduras e infecciosas (Freed, 1998).

As partículas de retrovírus são geralmente partículas esféricas envelopadas com um diâmetro médio variando entre 100 a $200 \mathrm{~nm}$. Analisando mais especificamente, a produção de partículas maduras e infecciosas de HIV é feita através de duas etapas: o brotamento da partícula madura não-infecciosa e maturação para vírion infeccioso. A formação de partículas requer o transporte da poliproteína viral Gag para a membrana plasmática, onde se associa com componentes celulares e virais para produzir uma estrutura de brotamento. As partículas são liberadas a partir da superfície celular como, 
partículas imaturas não-infecciosas contendo uma camada esférica de poliproteínas Gag sob a membrana viral. A atividade da protease viral (PR) na poliproteína inicia a maturação viral ao mesmo que o brotamento. A clivagem proteolítica nos locais definidos, em uma ordem definida, leva à formação de proteínas da matriz (MA), do capsideo (CA), nucleocapsídeo (NC), P6 e dois peptídeos menores. O processamento proteolítico não é necessário para a formação de partículas ou brotamento (Figura 26) (Vogt, 1997; Briggs et al., 2003).

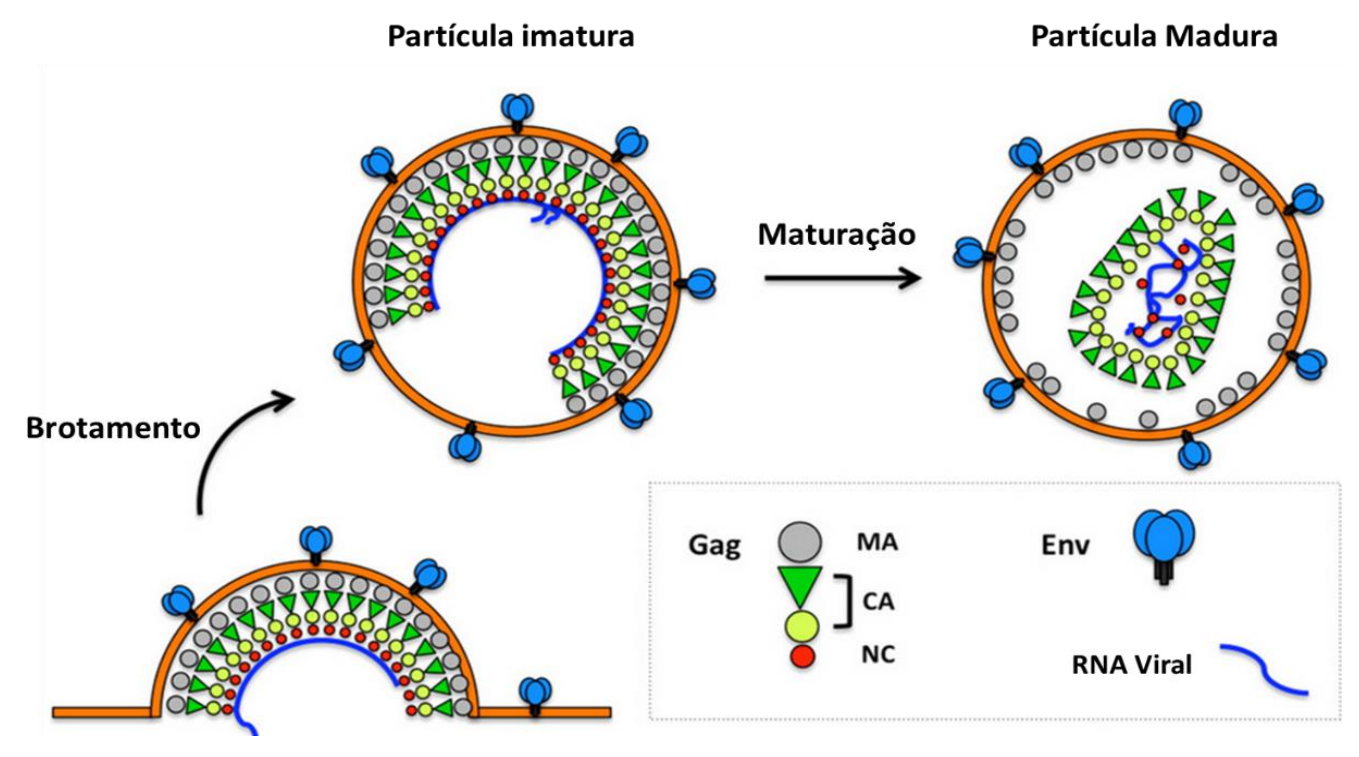

Figura 26. Montagem de partículas retrovirais. O desenho mostra três estágios da formação das partículas virais: morfogênese de uma partícula retroviral parcialmente montada sob a membrana plasmática da célula hospedeira, uma partícula imatura que é composta de uma estrutura moldada por Gag, e uma partícula de vírus madura, que tem um núcleo distinto. Gag é uma poliproteína constituida por proteína de matriz (MA), capsídeo (CA) e proteína da nucleocapsídeo (NC). Env representa o complexo trimérico do envelope. Figura adaptada de Zhang et al., 2015. 
O precursor de Gag (Pr55) de HIV-1 por si só é suficiente para criar vesículas revestidas com Gag que brotam para o espaço extracelular, como "Virus like-particles VLPs" (Gheysen et al., 1989). A montagem de uma VLP de HIV-1 foi observada usando microscopia de fluorescência de reflexão interna total - TIRFM ("Total internal reflection fluorescence microscopy”, uma técnica utilizada para observar moléculas fluorescentes na superfície ou interface de uma amostra. Essa técnica permite observar, por exemplo, diferentes eventos que ocorrem na superfície celular). Esses estudos mostraram que a formação de VLP de HIV-1 inicia na membrana plasmática e continua através da polimerização de Gag, resultando em vírions totalmente formados (Jouvenet et al., 2008).

Gag consiste em três regiões estruturais $\mathrm{MA}, \mathrm{CA}$, e $\mathrm{NC}$, e três regiões não estruturais SP1, SP2, e P6. O domínio MA é essencial para o direcionamento de Gag para a parte interna da membrana plasmática, e contém um sítio de ligação PIP2 (interface entre o domínio transmembrana e o domínio citoplasmático), bem como um motivo para miristoilação, o que contribui para a ligação à membrana. Os domínios CA se ligam uns aos outros com forte afinidade e essas interações são fundamentais para arranjos hexagonais de Gag dentro de vírions de HIV imaturos. Essas regiões são suficientes e necessárias para a produção de VLPs de HIV-1 (Ku et al., 2013). Assim, VLPs de HIV1 começaram a ser estudadas quanto ao seu potencial para o desenvolvimento de uma vacina contra o vírus HIV e também em novas formas de diagnóstico.

VLPs baseadas na expressão de $\operatorname{Pr} 55$ + Env são imunogênicas e capazes de induzir resposta celular e humoral (Guerbois et al., 2009). Porém VLPs baseadas 
somente na expressão de Pr55 com sua natureza não-replicativa, similaridade com vírus naturais e ausência do material genético, torna as VLPs uma plataforma interessante para a concepção de vacinas de subunidades que carregam as estruturas imunogênicas de outros vírus, além de também induzirem a resposta imune (Chua et al., 2013).

\section{4. Baculovírus como vetor de expressão para produção de VLPs}

Outra utilização já bem estabelecida do Baculovírus como vetor de expressão em células de inseto, é a produção de VLPs (“Virus like particles”). VLPs são compostas de proteínas do capsídeo viral que se auto-montam em partículas que lembram os vírions naturais de que derivam (Fernandes et al., 2013). As VLPs são de replicação, bem como, de infecção incompetentes, devido à ausência de qualquer material genético infeccioso. Sendo um poderoso sistema de expressão eucariótico capaz de fazer modificações póstraducionais complexas, o sistema de expressão Baculovírus x células de inseto é capaz de atuar na correta auto-montagem e liberação de partículas VLP (Figura 27) (Liu et al., 2013). 


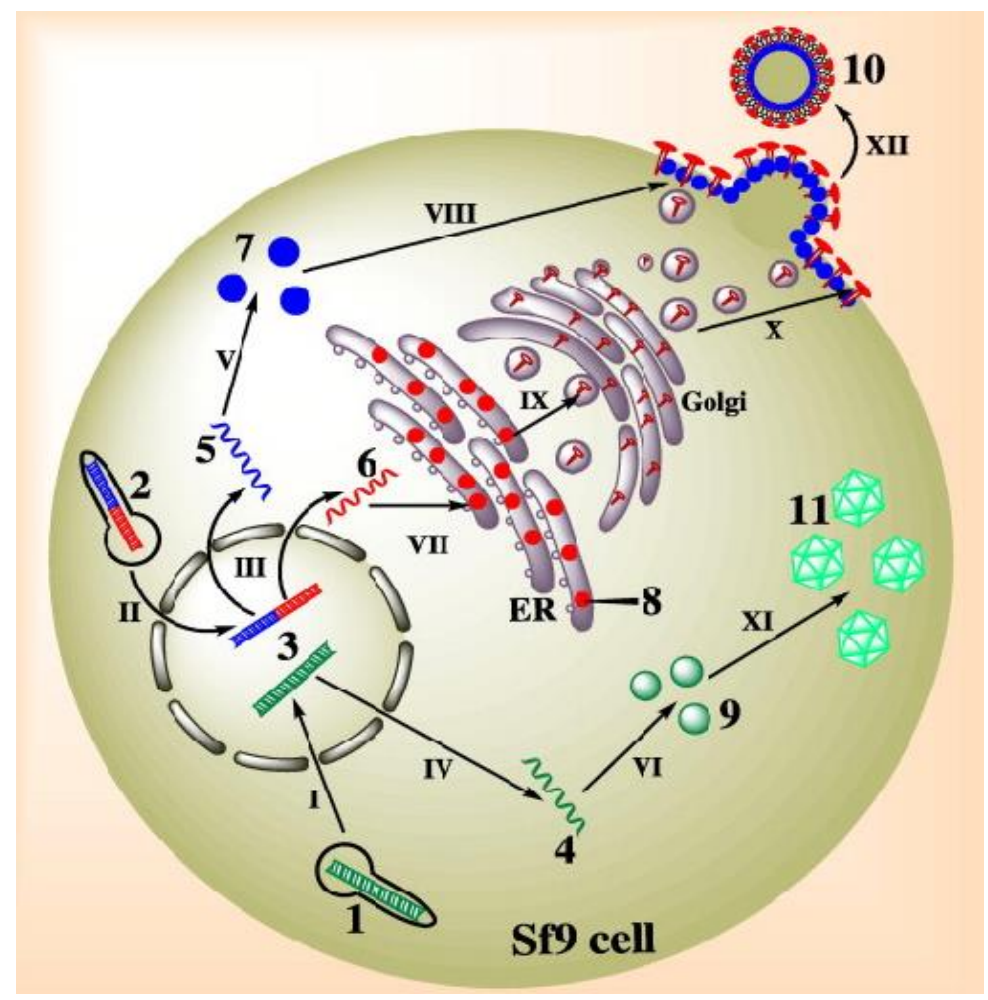

Figura 27. Principais fases da formação de VLPs envelopados e não envelopados em células de inseto. 1 e 2, os baculovírus recombinantes; 3, o genoma de baculovírus; 4, 5 e 6, mRNAs; 7, proteína de matrix ou capsídeo; 8, proteína da membrana; 9, a proteína da capsídeo; 10, VLP envelopada; 11, VLP não envelopada; ER, retículo endoplasmático. I e II, os genomas de baculovírus ganham acesso ao núcleo. III e IV, mRNAs são exportados a partir do núcleo. V, VI e VII, os mRNAs são traduzidos em proteínas estruturais. VIII, subunidades de proteínas de matriz são transportados para a membrana plasmática. IX e X, as proteínas da membrana são transportadas através do aparelho de Golgi para a membrana plasmática. XI, subunidades da proteína do capsídeo são montados em VLPs sem envelope. XII, VLPs envelopadas brotam a partir da superfície da célula (Liu et al., 2013). 
Um caso de sucesso e aplicação de VLPs na indústria é a vacina contra o Papilomavírus humano (HPV). A vacina utilizada contra o HPV subtipos 16 e 18 é baseada na produção de VLPs utilizando células de inseto e baculovírus como vetor de expressão. A vacina comercial Cervarix ${ }^{\circledR}$ (GlaxoSmithKline Biologicals) é amplamente utilizada e uma ferramenta eficaz contra o HPV.

Como o sistema de expressão de baculovírus é muito versátil e eficaz na expressão de proteínas heterólogas utilizando diferentes métodos, a comparação das diferentes estratégias de expressão se faz necessária. Expressão de diferentes proteínas de interesse podem causar modificações morfológicas que podem levar a defeitos na partícula viral e prejudicar a correta expressão e eficácia do método. É necessário escolher a estratégia mais adequada para expressão da proteína de interesse, isso pode ser mais viável econômicamente e também ser mais seguro. Em comparação com as vacinas de peptídeos, as vacinas de VLP são altamente imunogênicas e a maioria das partículas VLPs produzidas neste método são capazes de induzir títulos muito elevados de anticorpos neutralizantes, muitas vezes na ausência de adjuvantes, e essas respostas são mantidas por longos períodos (Wang \& Roden, 2013)

Durante o brotamento de VLPs de HIV-1 produzidas utilizando o sistema baculovírus de expressão, proteínas GP64 de baculovírus foram encontradas na superfície dessas VLPs. Como essa proteína de envelope baculoviral é expressa na superfície de células infectadas, quando a GAG de HIV está se montando em VLPs, acaba incorporando GP64 na superfície dessas partículas.

Sabe-se que os baculovírus podem eficientemente entrar em células de mamífero através de transdução; e que a proteína GP64 é diretamente envolvida neste processo 
(Kataoka et al., 2012). O mecanismo exato de como partículas de baculovírus são internalizadas em células de mamífero ainda permanece desconhecido. Porém, foi mostrado que o polissacarídeo Sulfato de heparano (encontrado na superfície de células animais) é essencial neste processo, atuando como receptor celular para a proteína GP64 (Wu \& Wang, 2011).

A proteína GP64 na superfície de VLPs de HIV-1 facilitou a entrada dessas partículas em células de mamífero. Porém, a resposta imune também foi desencadeada contra GP64, o que pode diminuir a especificidade da resposta imune à VLP (ValleyOmar et al., 2011).

Um sistema que consegue produzir VLPs livres de GP64, as tornando mais parecidas às partículas de HIV-1 naturais, seria de grande valia para a indústria farmacêutica, pois juntaria a facilidade e os baixos custos provenientes do sistema baculovírus de expressão e a especificidade da resposta imune as proteínas expressas por uma VLP. Neste trabalho, uma nova forma de produzir VLPs foi desenvolvida e esta pode ser usada como plataforma para expressão de outras proteínas imunogênicas virais. 


\section{Objetivo}

Produção de VLPs de HIV-1 usando baculovírus com e sem o gene da proteína de envelope GP64 e uso dessas VLPs para incorporação de proteínas recombinantes.

2.1. Objetivos específicos

- Produção de baculovírus recombinantes contendo os genes da proteína GAG de HIV-1 em sistema GP64 + e GP64 -;

- Avaliação e confirmação da correta expressão da proteína GAG;

- Análise do perfil de expressão de GAG e proteínas baculovirais em VLPs purificadas;

- Análise da separação de VLPs e partículas de baculovírus utilizando centrifugação em gradiente de sacarose;

- Análise da produção de VLPs de HIV-1 produzidas em células de inseto e confirmação da ausência de GP64 por microscopia eletrônica de transmissão. 


\section{Material e Métodos}

\subsection{Vírus e células}

O vírus Autographa californica multiple nucleopolyhedrovirus (AcMNPV) e baculovírus recombinantes derivados do AcMNPV na forma de bacmídeo bMON14272, “Bac-to-Bac $®$ "Baculovirus Expression System” da empresa Invitrogen foram utilizados nesse trabalho.

Os vírus selvagens e os recombinantes (GP64+) foram propagados em cultura de células Trichoplusia ni (BTI-Tn5B1-4 ou Tn5B) (Granados et al., 1994) ou em cultura de células Spodoptera frugiperda (Sf9) (Vaughn et al., 1977). Os vírus recombinantes (GP64-) foram propagados em cultura de células Spodoptera frugiperda Sf9Op1D que possuem a proteína GP64 de Orgyia pseudotsugata multiple nucleopolyhedrovirus sendo expressa constitutivamente (Plonsky et al., 1999). Essas células foram mantidas em meio TC-100 (Gibco-BRL) com $10 \%$ de soro fetal bovino a $27^{\circ} \mathrm{C}$ (Invitrogen).

Células Sf9 - ET ("Easy Titer") foram utilizadas para titulação de todos os vírus utilizados neste trabalho (Hopkins \& Esposito, 2009).

Células de Escherichia coli DH5- $\alpha$ (Invitrogen) foram utilizadas como hospedeiras para a maior parte dos plasmídeos utilizados no presente trabalho.

Os experimentos envolvendo Bac-to-Bac ${ }^{\circledR}$ "Baculovirus Expression System" (Invitrogen) foram utilizadas células Escherichia coli DH10Bac (Invitrogen). 
3.2. Obtenção do plasmídeo que contém o gene gag de HIV e construção dos baculovírus recombinantes

O plasmídeo 125-pFB-HIV-2gb (Figura 28) foi gentilmente cedido pelo professor Volker M. Vogt da Universidade Cornell - Estados Unidos. O plasmídeo 125-pFB-HIV$2 \mathrm{gb}$ foi utilizado na construção de baculovírus recombinantes, sendo um GP64 + e outro GP64 - utilizando o sistema Bac-to-Bac® (Invitrogen) descrito no capítulo I item 3.5 e 3.6. Porém, para a produção do baculovírus recombinante que possui o gene gag de HIV além de possuir o gene gp64 deletado, foi utilizado uma bactéria DH10Bac que possui o gene de resistência a clorafenicol (CAT - Clorafenicol acetiltransferase) no lócus do gene da proteína GP64, essa linhagem de bactéria foi cedida pelo professor Gary W. Blissard da Universidade de Cornell (EUA) e utilizada no sistema Bac-to-Bac ${ }^{(I n v i t r o g e n) . ~}$

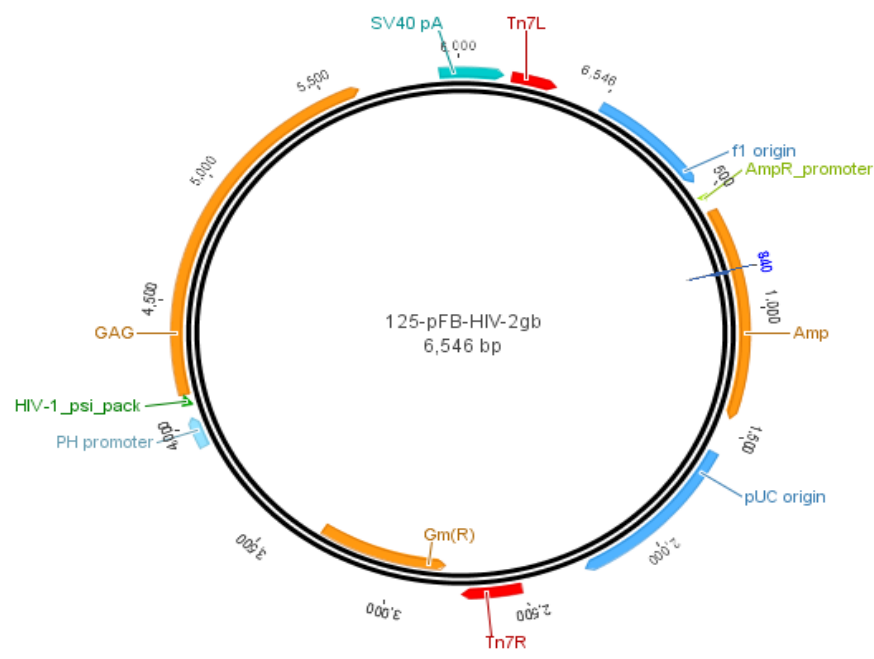

Figura 28. Esquema representativo do plasmídeo 125-pFB-HIV-2gb. Na figura é possível ver o gene de resistência a Ampicilina (Amp) e seu promotor, gene de resistência a Gentamicina (Gm), regiões de transposição Tn7R e Tn7L, origem de replicação pUC e origem de replicação f1 (esse plasmídeo possui duas origens de replicação para gerar um maior número de cópias), sinal de poliadenilação SV40, sinal de encapsidação (psi-pack) e o gene gag HIV-1 sob o comando do promotor da poliedrina. Desenvolvido usando o programa Geneious (Biomatters Limited). 
Os bacmídeos produzidos neste trabalho foram confirmados por PCR seguindo as instruções do fabricante do sistema Bac-to-Bac ${ }^{\circledR}$ (Invitrogen). Os vírus recombinantes foram obtidos após transfecção de células de inseto com os bacmídeos recombinantes e depois amplificados e titulados como descrito no capítulo 1 ítem 3.5. A confirmação da expressão das proteínas recombinantes foi feita em gel SDS-PAGE 12\% (Laemmli, 1970) utilizando o aparato Mini Protean II (BioRad) e por Western blot utilizando o anti-soro monoclonal anti-GAG p24 (NIH AIDS Reagent Program), as etapas da confirmação por Western blot seguiram o mesmo protocolo descrito no capítulo 1 ítem 3.6.1, porém utilizando o anticorpo específico para a detecção de GAG. Assim foram construídos dois vírus recombinantes: vGAGHIV-1 (GP64+) e o vírus o vGAGHIV-1 GP64 null (GP64).

3.3. Análise da produção de BVs de baculovírus e VLPs (GAG HIV-1) após purificação em gradiente de sacarose

Foi feita a análise da expressão das proteínas baculovirais (GP64 e VP39 - utilizando anti-VP39 policlonal cedido pelo Dr. Gary W. Blissard e monoclonal anti-GP64 AcV5 comercial - Abcam $^{\circledR}$ ) e da proteína retroviral GAG (Monoclonal Anti-Gag p24 NIH AIDS Reagent Program), no sobrenadante de células Sf9 infectadas com os vírus vGAGHIV-1 e AcMNPV. Após 72 h p.i., o sobrenadante foi coletado e ultracentrifugado por $2 \mathrm{~h}$ em colchão de sacarose $25 \%$ e a 150.000 x $g$. O precipitado foi então ressuspendido em 200 $\mu 1$ de PBS $1 \mathrm{X}$ e colocado no topo de um gradiente de sacarose $30-60 \%$ e centrifugado a 150.000 x g por $18 \mathrm{~h}$ ou “Overnight”. Após a purificação por gradiente de sacarose, todo o gradiente foi coletado em alíquotas de $600 \mu$ l, adicionado $900 \mu \mathrm{l}$ de PBS 1X e 
ultracentrifugado por mais $2 \mathrm{~h}$ a $130.000 \mathrm{x} g$. As partículas purificadas foram analisadas em SDS-PAGE 12\% (Laemmli, 1970) usando o aparato PROTEAN ${ }^{\circledR}$ II xi Cell. Após eletroforese, o gel foi corado por $18 \mathrm{~h}$ com Comassie blue (40\% de metanol e $10 \%$ de ácido acético, 0,1\% de corante Azul brilhante de Coomassie R-250) e a comparação do perfil de expressão dessas proteínas, bem como sua quantificação e avaliação da possibilidade de separação de BVs e VLPs foram avaliados utilizando Fluorescent Western Scanning - Odyssey Infrared Imaging System, que permite a análise e quantificação da expressão das proteínas por escaneamento de géis de poliacrilamida corados com Comassie blue ou incubados com anticorpos fluorescentes, a quantificação das proteínas foi feita usando software do próprio scanner, seguindo instruções do fabricante.

No caso do vírus vGAGHIV-1 GP64 null, para avaliação da deleção de GP64, células Sf9 foram infectadas (m.o.i 1) e $72 \mathrm{~h}$ p.i., o extrato total foi utilizado em um Western blot (mesmas especificações anteriores) com os anticorpos Anti-VP39, Anti-GP64 e AntiGAG, os mesmos testados para os experimentos com os vírus GP64 +. Uma vez que a membrana com as amostras do extrato celular de células infectadas com AcMNPV, vGAGHIV-1 e vGAGHIV-1 GP64 null eram testadas com um anticorpo, logo após a revelação, a membrana era lavada, bloqueada e incubada com o próximo anticorpo, testando, assim, a mesma membrana com os três anticorpos usados nesse experimento. $\mathrm{O}$ mesmo experimento foi feito, usando membranas individuais para cada anticorpo. 
3.4. Contrastação negativa e análise do perfil de brotamento VLPs e BVs por Microscopia Eletrônica de Transmissão (MET)

Partículas purificadas por gradiente de sacarose foram analisadas por contrastação negativa em um microscópio eletrônico de transmissão - MET (Brenner \& Horne, 1959). Partículas purificadas foram colocadas em contato com telas de níquel cobertas com carbono por 30 min. Após incubação da amostra, a tela de níquel foi lavada 3 vezes com PBS 1X e contrastada negativamente com PTA (ácido fosfo-túngstico) a 2\% durante 2 min e analisados em um MET (Jeol 1011).

Para análise do perfil de brotamento em células de inseto, células Tn5B foram infectadas (m.o.i 1) com AcMNPV e vGAGHIV-1 e 72 h p.i. foram lavadas com PBS 1X $\mathrm{pH}$ 6,4 e fixadas durante $1 \mathrm{~h}$ com fixador Karnovsky (2\% glutaraldeído e $2 \%$ de paraformaldeído tamponado em 0,1M de tampão cacodilato de sódio pH 6,4) com 5\% de sacarose. Após fixação, as amostras foram centrifugadas $(8.000 \times \mathrm{x}$ por $5 \mathrm{~min})$ e o precipitado foi lavado três vezes por 5 min em $0,1 \mathrm{M}$ de tampão cacodilato de sódio $\mathrm{pH}$ 6,4. Após lavagem, foram pós-fixadas em $1 \%$ de tetróxido de ósmio durante 30 min, 0,8\% de ferricianeto de potássio e $5 \mathrm{mM}$ de cloreto de cálcio em $0,1 \mathrm{M}$ de tampão cacodilato de sódio pH 6,5. Foram, então, lavadas três vezes com água destilada e contrastadas in bloc "overnight" com $0,5 \%$ de acetato de uranila. Depois, foram desidratadas em concentrações crescentes de acetona (30-100\%) por 5 min e incluídas em resina Spurr e emblocadas por $72 \mathrm{~h} \mathrm{a} 60^{\circ} \mathrm{C}$. Após ultramicrotomia (Leica EM UC7), secções ultrafinas das amostras foram colocadas sobre telas de níquel e analisadas no MET. 


\subsection{Imunomarcação de VLPs de HIV-1 e análise por MET}

Células Sf9 foram infectadas (m.o.i 1) com AcMNPV, vGAGHIV-1 e vGAGHIV1 GP64 null e a 72 h p.i. foram fixadas, lavadas em PBS $1 \mathrm{X}$ e fixadas com $4 \%$ de paraformaldeído, $0,5 \%$ de glutaraldeído e $0,01 \%$ de ácido pícrico em $0,1 \mathrm{M}$ de tampão cacodilato de sódio pH 6.4 com 5\% de sacarose. Após a fixação, as células foram lavadas duas vezes em 0,1 M de tampão cacodilato de sódio pH 6,4 seguido de incubação por $1 \mathrm{~h}$ com 50 mM de cloreto de amônio. As amostras foram então lavadas duas vezes em água destilada contrastadas in block "overnight" com acetato de uranila $2 \%$, no escuro a $4^{\circ} \mathrm{C}$. Depois, foram novamente lavadas (duas vezes) em água destilada e desidratadas em concentrações crescentes de acetona (30-90\%) por 10 min em cada concentração. Finalmente, foram incluídas em resina LR Gold e emblocadas por 72 h a $-20^{\circ} \mathrm{C}$ sob luz ultravioleta.

Secções ultrafinas das amostras emblocadas foram colocadas em telas de níquel e incubadas por 30 min em $80 \mathrm{mM}$ de cloreto de amônio diluído em PBS 1X. Após essa primeira incubação, as telas de níquel contendo as amostras, foram incubadas com solução de bloqueio $(0,01 \%$ de Tween $20,1,5 \%$ de BSA e PBS 1 X) à temperatura ambiente. Após incubação com solução de bloqueio, as amostras foram incubadas por 1 h com o anticorpo primário (monoclonal anti-GP64 AcV1 que reconhece um epítopo conformacional da proteína GP64) diluído em solução de bloqueio diluído 1:50. Depois foi incubado com o anticorpo secundário (anti-IgG de camundongo conjugado com partículas de ouro coloidal de $10 \mathrm{~nm}$ ) diluído em solução de bloqueio em uma proporção de 1:20. As amostras foram, então, lavadas duas vezes em PBS 1X e uma vez em água destilada e analisadas no MET. 


\section{Resultados}

4.1. Confirmação da expressão de GAG em células de inseto

O plasmídeo 125-pFB-HIV-2gb foi utilizado na construção dos vírus recombinantes contendo os genes gag de HIV-1, GP64+ e GP64-, pelo sistema Bac-to$\mathrm{Bac}^{\circledR}$ Invitrogen. Inicialmente, células de inseto (Sf9) foram infectadas com o vírus AcMNPV e o vírus recombinante vGAGHIV-1 produzido neste trabalho, a fim de comparação do perfil de expressão de BVs e VLPs e observar a possibilidade de separação de ambas a partículas. A 72 h p.i., o sobrenadante foi coletado e centrifugado em colchão de sacarose e, posteriormente, centrifugado em gradiente de sacarose para purificação das partículas virais, tanto VLPs quanto BVs. Tanto no gradiente utilizado para purificar BVs provenientes da infecção de células Sf9 com AcMNPV quanto no gradiente utilizado para purificar VLPs e BVs provenientes da infecção de células Sf9 com vGAGHIV-1, somente uma banda branca foi observada no terço inferior dos gradientes (Figura 29). 
A

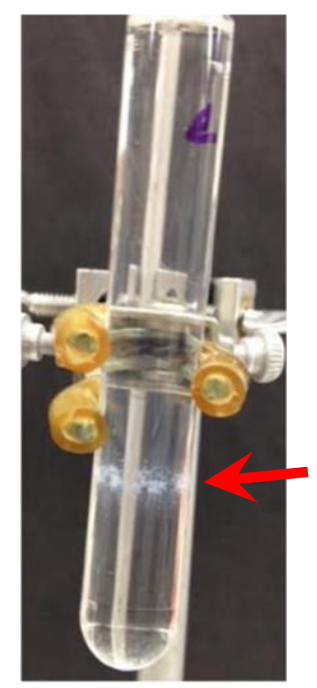

AcMNPV
B

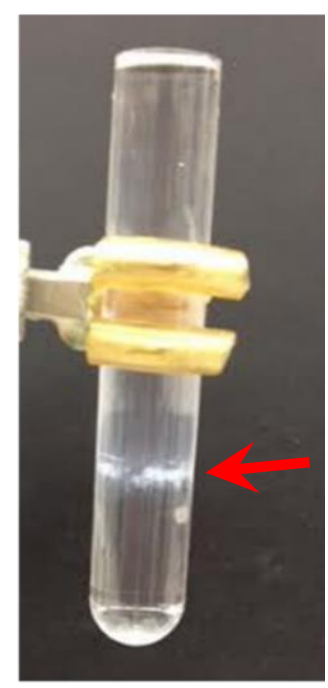

vGAGHIV-I

Figura 29. Foto dos gradientes de sacarose utilizados para purificar BVs e VLPs. A) Tubo de ultracentrífuga contendo gradientes de sacarose (30-60\%) após centrifugação para purificar BVs provenientes de células Sf9 infectadas com AcMNPV (m.o.i 1) B) Tubo de ultracentrífuga contendo gradiente de sacarose (3060\%) após centrifugação para purificar BVs e VLPs provenientes de células Sf9 infectadas com vGAGHIV1 (m.o.i 1). Observa-se a formação de somente uma banda branca no terço inferior de ambos os gradientes (setas).

Apesar de somente uma banda ser visível nos gradientes (esperava-se ver duas bandas no gradiente, uma correspondente as VLPs e outra aos BVs), frações de ambos os gradientes foram coletadas e avaliadas por eletroforese em gel de poliacrilamida, objetivando ver o padrão e a possibilidade de separação das partículas. O perfil de expressão das proteínas GP64, GAG e VP39 foi avaliado e quantificado usando scanner infravermelho que permite a avaliação e quantificação de proteínas em gel de poliacrilamida. Observa-se que em aproximadamente $1.19 \mathrm{~g} / \mathrm{ml}$ de sacarose, o sinal para as proteínas GP64 e VP39 são mais fortes, o que significa que nesta densidade podemos concentrar BVs purificados e coletá-los. As partículas purificadas a partir dessa região do 
gradiente foram analisadas usando contrastação negativa por MET e pode-se, então, ver a presença de BVs nessa região. Neste experimento controle, a quantificação para GP64 nessa fração do gradiente, foi de aproximadamente $2,3 \mu \mathrm{g}$ e para VP39 foi de aproximadamente $0,7 \mu \mathrm{g}$ (Figura 30).

A

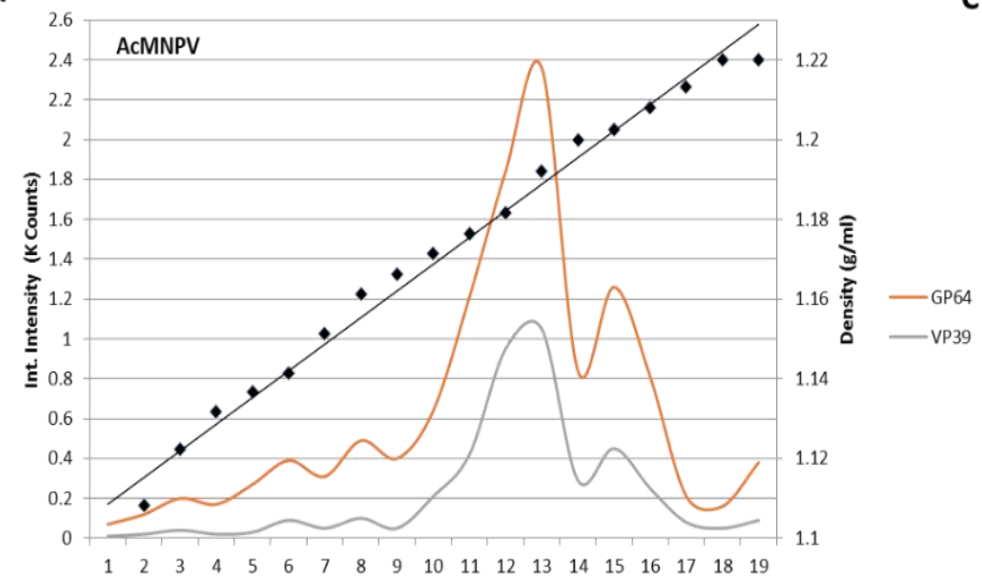

B $\mathrm{kDa}$

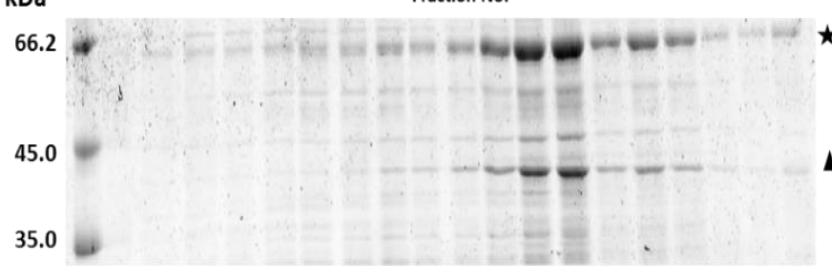

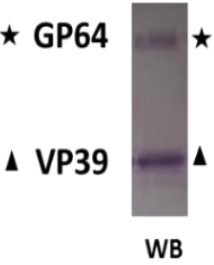

C

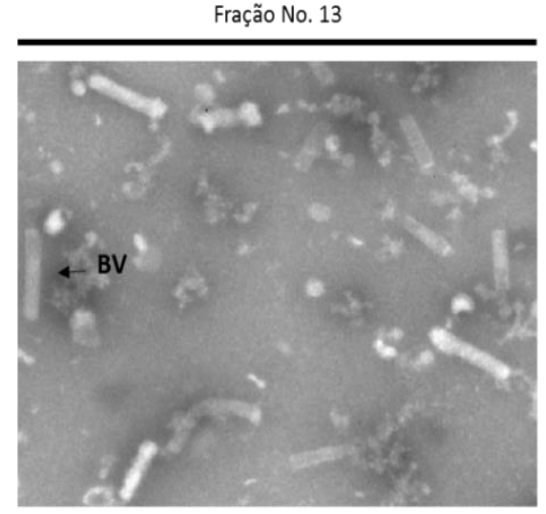

D

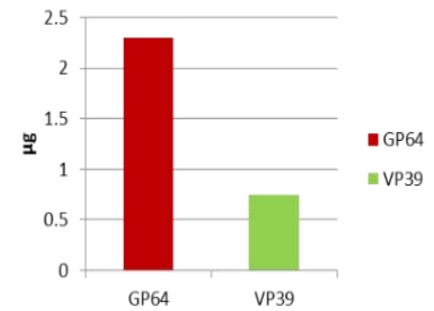

Figura 30. Análise da separação de BVs a partir de sobrenadante de células Sf9 infectadas com AcMNPV A) Análise do perfil de separação das partículas BV (através do sinal para GP64 e VP39) de baculovírus em gradiente de sacarose (30-60\%) B) SDS-PAGE 12\% das frações do gradiente e WB da fração 13 utilizando anticorpo monoclonal Anti-GP64 $\star$ e policlonal Anti-VP39 $\Delta$ C) Contrastação negativa das partículas purificadas a partir da fração 13 do gradiente de sacarose, mostrando partículas BV presentes na amostra (seta) D) Quantificação das proteínas GP64 e VP39 presentes nas partículas BVs purificadas na fração 13 do gradiente de sacarose.

Depois de avaliar a separação de partículas BVs a partir de células Sf9 infectadas com o vírus selvagem AcMNPV e todas as condições para essa purificação, o mesmo 
experimento foi feito, mas desta vez, infectando células Sf9 com o vírus vGAGHIV-1, que expressa a proteína GAG de HIV-1 e produz VLPs e BVs durante o ciclo de infecção com o baculovírus recombinante. As condições de purificação e separação dessas partículas foram avaliadas, bem como foi feita a quantificação das proteínas GP64, VP39 e GAG (Figura 31).
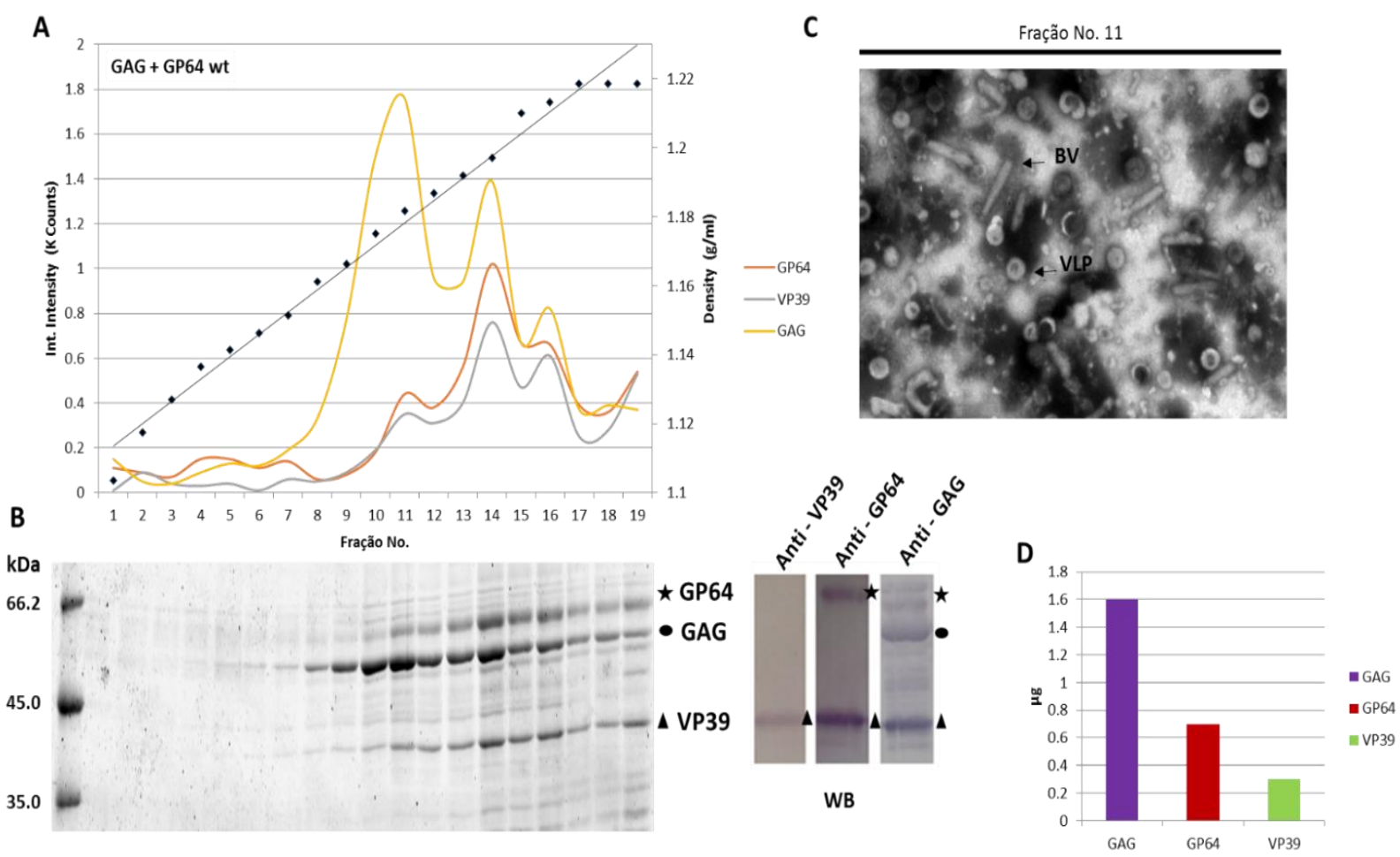

Figura 31. Análise da separação de BVs e VLPs a partir de sobrenadante de células Sf9 infectadas com vGAGHIV-1 A) Análise do perfil de separação das partículas BV (através do sinal para GP64 e VP39) de baculovírus e VLPs (através do sinal para GAG) em gradiente de sacarose (30-60\%) B) SDS-PAGE 12\% das frações do gradiente e Western Blot - WB (utilizando a mesma membrana e fazendo a sobreposição dos anticorpos) da fração 11 utilizando anticorpo monoclonal Anti-GP64 $\star$, policlonal Anti-VP39 $\Delta$ e monoclonal Anti-GAG • C) Contrastação negativa das partículas purificadas a partir da fração 11 do gradiente de sacarose, mostrando partículas BVs e VLPs presentes na amostra (seta) D) Quantificação das proteínas GP64, VP39 e GAG presentes nas partículas BVs purificadas na fração 13 do gradiente de sacarose. 
Após os experimentos para análise do perfil de separação de BVs e VLPs através de gradiente se sacarose, observou-se que mesmo na fração que mostra o maior sinal para GAG e, consequentemente, para VLPs, o sinal para proteínas baculovirais ainda é muito significativo. Observa-se que na fração em que GAG é expressa em maior quantidade ( 1,6 $\mu \mathrm{g})$, o sinal de GP64 ( 0,6 $\mu \mathrm{g})$ e VP39 ( 0,3 $\mu \mathrm{g})$ é diminuído, mas ainda presente na amostra, mostrando que em um mesmo gradiente, mesmo que VLPs e BVs estabilizem em diferentes densidades de sacarose, as partículas de baculovírus BVs ainda se fazem presentes.

\subsection{Produção e caracterização de VLPs "GP64 free”}

Sabendo da necessidade comercial de VLPs puras e livres de partículas ou proteínas provenientes dos vetores de expressão, e também da impossibilidade da separação dessas partículas por gradiente de sacarose, uma nova técnica "GP64 free" foi testada. Um baculovírus recombinante que possui a proteína GP64 de baculovírus deletada e expressa GAG de HIV- 1 (vGAGHIV-1 GP64 null) foi construído e confirmado como citado no item 3.2. Porém, sabe-se que a proteína GP64 é necessária para a entrada de partículas baculovirais na célula alvo, portanto, uma célula de inseto especial (Sf9 ${ }^{\mathrm{Op1D}}$ ), que possui GP64 de OpMNPV sendo expressa constitutivamente, foi utilizada para a propagação desse vírus (Plonsky et al., 1999). Essa célula foi testada em ensaio de fusão usando diferentes pHs e sua viabilidade para expressão de GP64 confirmada (Figura 32). 


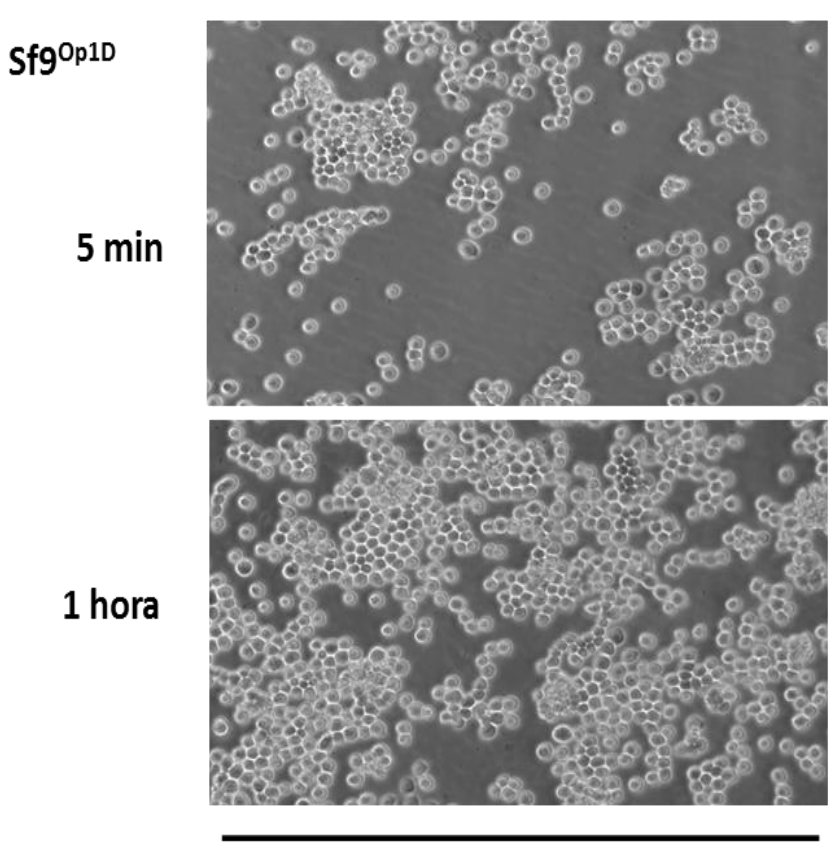

pH 6.2
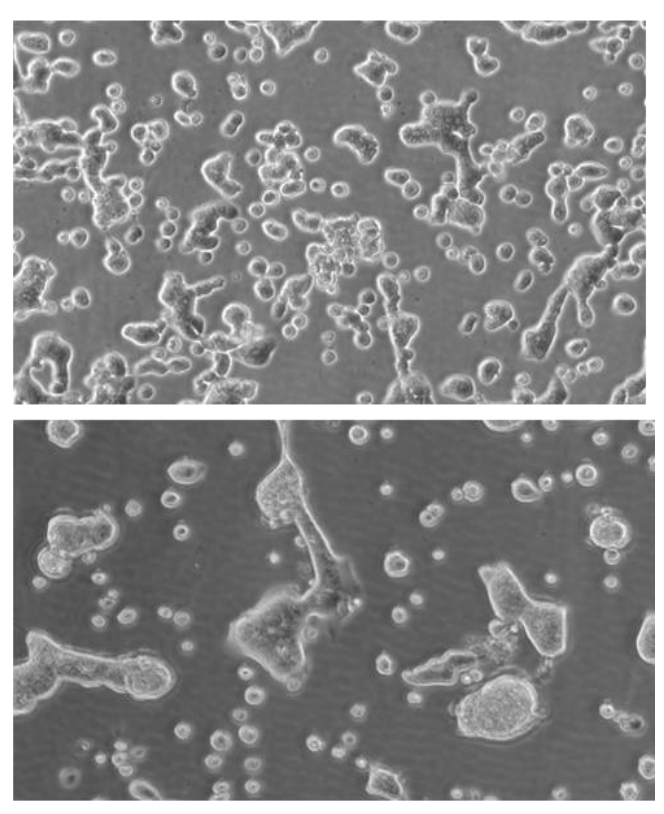

pH 5.1

Figura 32. Ensaio de fusão da célula Sf9Op1D. Células Sf9 ${ }^{\text {Op1D }}$ foram tratadas com PBS estéril $1 \mathrm{X}$ pH 6.2 ( $\mathrm{pH}$ comum de meios de cultura de células de inseto) e pH 5.1 (pH ácido que ativa a função de proteína de fusão da GP64) durante 5 min e 1 h. Após 5 min as células começam a se fusionar umas com as outras e após 1 h quase todas as células estão fusionadas, demonstrando a correta expressão da proteína GP64 nessas células.

Após produção do baculovírus recombinante vGAGHIV-1 GP64 null, células Sf9 foram infectadas com AcMNPV, vGAGHIV-1 e vGAGHIV-1 GP64 null e 72 h p.i., o extrato celular foi testado com os anticorpos Anti-GP64, Anti-VP39 e Anti-GAG. O experimento mostrou que o sinal para a proteína GP64 em células infectadas com vGAGHIV-1 GP64 null não foi detectado, confirmando a deleção do gene que expressa essa proteína no vírus recombinante vGAGHIV-1 GP64 null (Figura 33). 


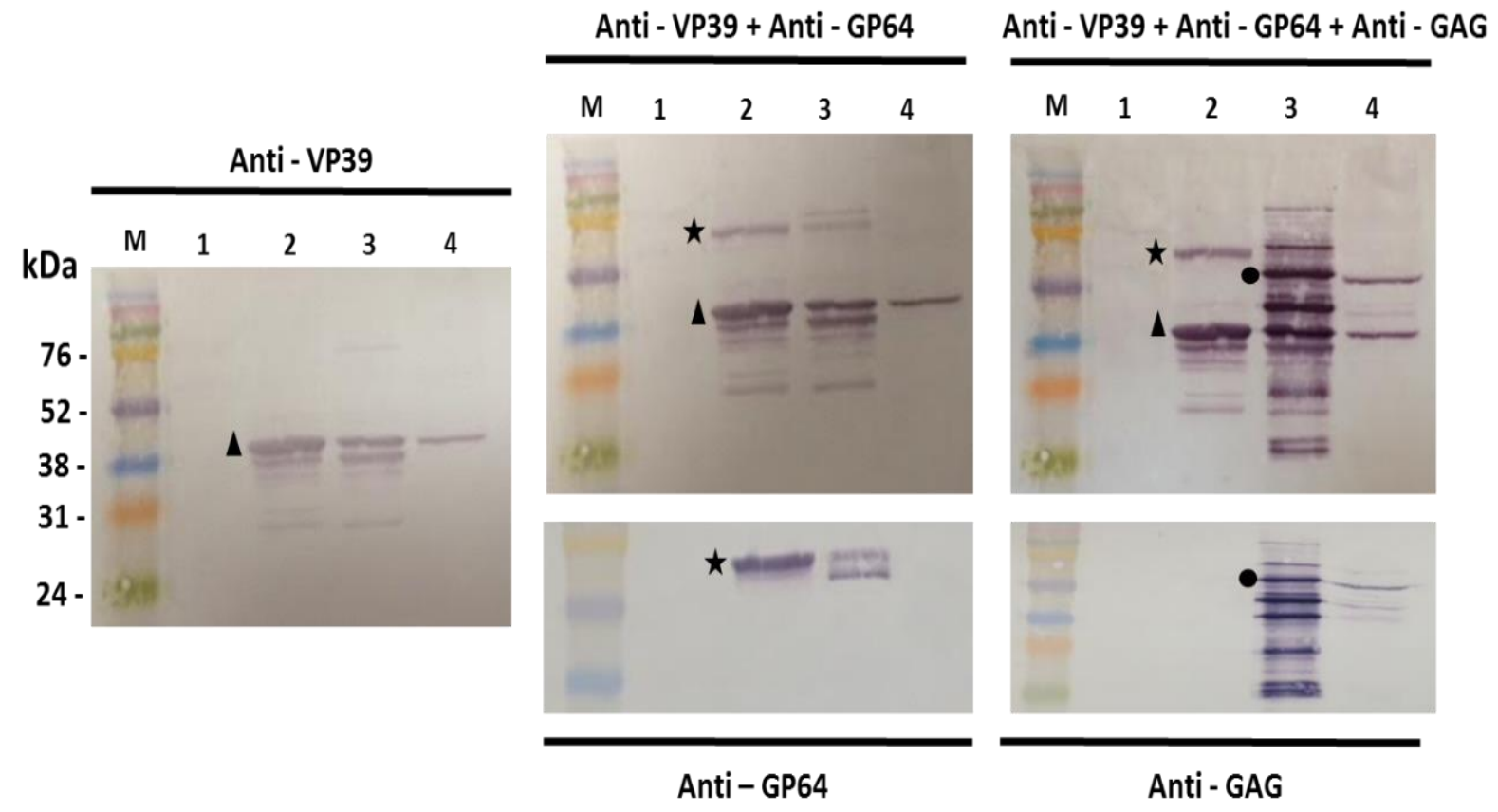

Figura 33. Western blot de extrato de células não-infectadas (Mock) (1) e infectadas com AcMNPV (2), vGAGHIV-1 (3) e vGAGHIV-1 GP64 null (4). Proteínas do extrato total de células Sf9 infectadas com m.o.i 1 dos vírus recombinantes e selvagem, foram separadas em gel de poliacrilamida e depois transferidas para membrana de nitrocelulose para deteç̧ão das proteínas VP39, GP64 e Gag nas amostras. A membrana foi incubada inicialmente com anticorpo policlonal Anti-VP39, depois a mesma membrana foi incubada com anticorpo monoclonal Anti-GP64 e por último a mesma membrana foi incubada com anticorpo monoclonal anti-GAG, o anticorpo é direcionado para o precursor de Gag Pr55, porém após processamento proteolítico de Gag, diferentes bandas podem ser visualizadas (p55, p47, p41 e CAp24). O sinal para a proteína GP64 é representado como $\star$, o sinal para VP39 é representado como $\Delta$ e o sinal para GAG é representado como $\bullet$. Membranas com as mesmas amostras foram incubadas individualmente com os mesmos anticorpos, como controle do experimento. 
Após a confirmação da deleção da proteína GP64, células Sf9 foram infectadas com os vírus vGAGHIV-1 e vGAGHIV-1 GP64 null para avaliação do perfil de brotamento das VLPs. Além disso, foi observado a presença ou ausência da proteína de envelope de baculovírus (GP64) na superfície dessas VLPs. As células Sf9 foram infectadas com o vGAGHIV-1 e vGAGHIV-1 GP64 null e 72 h p.i. células infectadas foram preparadas para imunomarcação com ouro e analisadas usando MET. A proteína GP64 foi facilmente visualizada na superfície de partículas VLP produzidas a partir de células Sf9 infectadas com vGAGHIV-1 (Figura 34 A e C). No entanto, as VLPs produzidas a partir de células Sf9 infectadas com vGAGHIV-1 GP64 null não tiveram marcação para presença da proteína GP64 (Figura 34 B e D). Sobrenadante de células Sf9 infectadas com vGAGHIV-1 e vGAGHIV-1 GP64 null foram utilizados para a purificação das partículas por ultracentrifugação e estas, analisadas por contrastação negativa (Figura 34 E e F). A presença de partículas purificadas confirmou a produção de VLPs livres de GP64 a partir de células de inseto infectadas com vGAGHIV-1 GP64 null. 

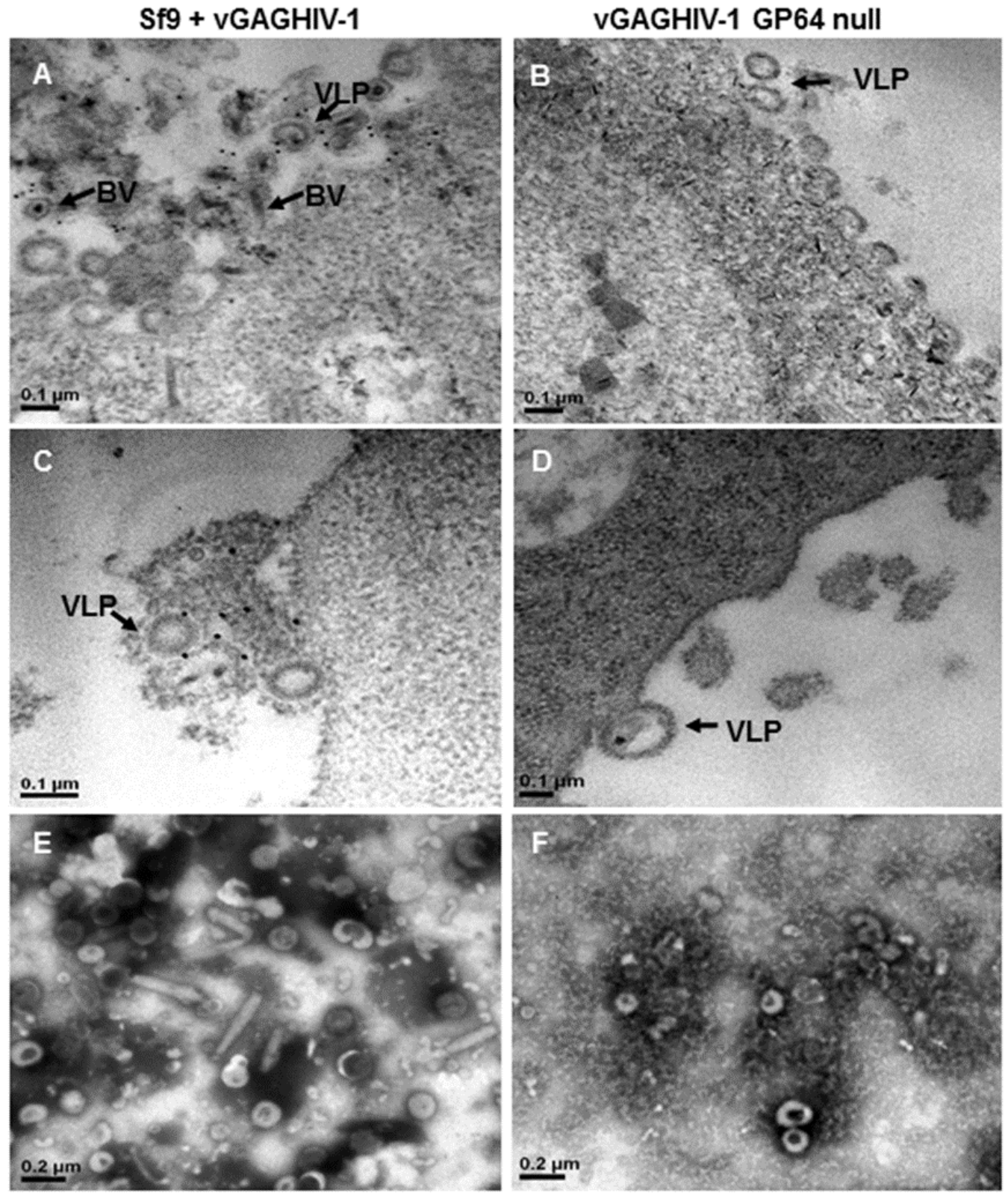

Figura 34. Análise por MET de VLPs de HIV-1 produzidas em células de inseto. As células Sf9 infectadas com vGAGHIV-1 e vGAGHIV-1 null foram coletadas $72 \mathrm{~h}$ p.i. e preparadas para imunomarcação com partículas de ouro. Para esse experimento foi utilizado um anticorpo monoclonal contra GP64 (AcV1), seguindo incubação com um anti-IgG de camundongo conjugado com partículas de ouro de $10 \mathrm{~nm}$ (A, B, C e D). Contrastação negativa de partículas BV e VLP purificadas (gradiente de sacarose) a partir de células Sf9 infectadas com vGAGHIV-1 e vGAGHIV-1 GP64 null (E e F). 


\section{Discussão}

A utilização de VLPs como ferramenta biotecnológica para produção de vacinas recombinantes ou em kits de diagnóstico, é uma alternativa segura, eficaz e muito mais acessível economicamente, principalmente quando estas são produzidas utilizando células de inseto e baculovírus como meio de expressão. Como citado anteriormente, a vacina contra HPV Cervarix ${ }^{\circledR}$ é produzida em células de inseto, utilizando o sistema baculovírus de expressão, e é comercialmente utilizada no combate do "Human papillomavirus" (HPV) subtipos 16 e 18, sendo comprovada a eficácia dessa vacina em até 7,3 anos pós vacinação (Thompson, 2016; Schwarz, 2009). Sabendo que VLPs são uma alternativa eficaz na produção de vacinas recombinantes, a produção de VLPs de diferentes vírus cresceu bastante nos últimos anos. Vírus como: Influenza, RSV (“Respiratory syncytial virus”), HIV, HCV (“Hepatitis C virus”), entre outros; já foram e estão sendo produzidos utilizando células de inseto e o sistema baculovírus de expressão. Porém, outras estratégias podem ser utilizadas para a expressão de VLPs, como células de mamífero, plantas, bactérias e leveduras (Fontana et al., 2016; Naskalska \& Pyrc, 2015; van Zyl \& Hitzeroth; 2016; Wahome et al., 2016), contudo, deve-se levar em consideração a diferença nos custos de produção relacionados aos diferentes métodos. Baculovírus e células de inseto são baratos e seguros na hora de manipulação (não replicam em células de mamífero e não são susceptíveis a contaminação por vírus ou parasitas humanos), além de ser um sistema eucariótico de expressão, facilitando a expressão de proteínas complexas ou que precisem de modificações pós-traducionais específicas (O’Reilly et al., 1992, Rohrmann, 2013). 
No caso da produção de VLPs de HIV-1, estudos que mostram a produção e caracterização dessas partículas, utilizando o sistema baculovírus de expressão já foram amplamente explorados. Essas VLPs já foram produzidas e avaliadas quanto as diferentes proteínas estruturais utilizadas na produção dessas partículas, bem como sua imunogenicidade (Visciano et al., 2011). Também já foram conduzidos estudos para avaliar a estabilidade estrutural dessas VLPs usando diferentes meios de cultura para produção e diferentes temperaturas de estocagem (Lynch et al., 2012). A linhagem celular, densidade e o melhor m.o.i ("Multiplicity of infection”) que deve ser utilizado para melhorar a produção dessas VLPs também já foi explorado (Pillay et al., 2009). Enfim, muito se sabe sobre a produção de VLPs de HIV-1 utilizando baculovírus e células de inseto, e todas as pesquisas e técnicas desenvolvidas ao longo dos anos foram muito importantes para consolidar a produção de VLPs de HIV-1 utilizando esse sistema. Também foram conduzidos estudos com diferentes métodos tentando separar BVs e VLP produzidas utilizando células de inseto, tais como cromatografia de exclusão de tamanho e cromatografia de afinidade, mas esses métodos são ineficazes para grandes e envelopadas VLPs (que é o caso da VLP de HIV-1) (Hu et al., 1999). Inativação de baculovírus em amostras de VLP purificadas por tratamento de Triton X-100 foi demonstrado em estudos anteriores, porém esta estratégia só funciona para VLPs pequenas e sem envelope. É importante enfatizar que os capsídeos de partículas de baculovirus ainda presentes nestas amostras tratadas com detergente pode ser um problema para a produção de vacinas (Rueda et al., 2012). Entretanto, nenhum estudo, ainda, foi capaz de separar completamente BVs e VLPs produzidos durante um mesmo ciclo de infecção viral. Durante o “delivery” do gene que codifica GAG - HIV- 1 (através 
de um baculovírus recombinante que expressa esse gene heterólogo) as partículas BVs de baculovírus são produzidas naturalmente, e é possível ver as duas partículas purificadas em um mesmo gradiente de sacarose (Chua et al., 2013). Além desse problema, durante a montagem das VLPs na membrana da célula, essas partículas podem capturar proteínas GP64 que estão presentes na superfície de células de inseto infectadas com baculovírus. Sabe-se que cada VLP de HIV-1 produzida utilizando sistema baculovírus de expressão, tem aproximadamente 1 molécula de GP64 para cada 3 moléculas GAG (Valley-Omar et al., 2011).

Sabendo que a proteína GP64 de baculovírus é altamente imunogênica (capaz de desencadear resposta imune específica) (Luo et al., 2013) e que está presente na superfície de VLPs produzidas utilizando baculovírus como sistema de expressão (Valley-Omar et al., 2011); a deleção dessa proteína e, consequentemente, de BVs, é muito importante para que as VLPs sejam puras e livres de proteínas do hospedeiro. Além do mais, essas VLPs "GP64 free" devem desencadear uma resposta imune muito mais específica, aumentando a especificidade e a resposta imune contra as proteínas estruturais de HIV-1, contribuindo para uma melhor eficiência na produção de uma vacina recombinante.

Durante este trabalho, foi construído um baculovírus recombinante que expressa GAG de HIV-1. Esse baculovírus recombinante foi utilizado na infecção de células de inseto e sua comparação com baculovírus AcMNPV selvagem analisada. Foi demonstrado que através de ultracentrifugação em gradiente de sacarose não é possível separar totalmente BVs e VLPs provenientes de células de inseto infectadas com esse vírus recombinante que expressa GAG, mesmo percebendo que as duas partículas se concentram em densidades diferentes no gradiente de sacarose. Esses achados nos levam 
a crer que quando essas VLPs, produzidas em células de inseto, são utilizadas na imunização de camundongos, geram uma resposta imune não específica para as VLPs, já que BVs também devem estar presentes nas amostras. Isso pode comprometer a eficácia na avaliação dessas VLPs como candidatas a uma vacina recombinante. Levando em consideração a impossibilidade de separação das partículas virais, faz-se necessário um sistema que bloqueie a produção de BVs e, ainda assim, permita a entrega do gene GAG de HIV-1 (neste caso) em células de inseto.

Plonsky et al. (1999) desenvolveram um sistema que bloqueia em mais de $90 \%$ a produção de BVs através da deleção da proteína de envelope GP64. Para que um vírus GP64 null seja amplificado, células Sf9Op1D (que expressam GP64 de OpMNPV) são utilizadas na amplificação e produção desses vírus. Porém, quando queremos utilizar vírus GP64 defectivo para bloquear a produção de BVs, células Sf9 devem ser infectadas normalmente com esse vírus, assim, o baculovírus GP64 null irá trabalhar somente como delivery do gene heterólogo e não será capaz de produzir a partícula viral BV. Com esse sistema, um baculovírus recombinante que expressa GAG de HIV-1 GP64 defectivo foi desenvolvido e utilizado na infecção de células Sf9. Por Western blot foi observado a perda do sinal da proteína GP64 de baculovírus no extrato de células infectadas quando comparado com os controles. Essas mesmas células foram visualizadas no MET, mostrando que mesmo quando GP64 não está presente, o brotamento de VLPs continua a acontecer. Também foi observado através de imunomarcação com partículas de ouro, a presença da proteína GP64 na superfície de VLPs produzidas a partir da infecção de células Sf9 com os vírus recombinantes vGAGHIV-1 e GAGHIV-1 GP64 null. Neste experimento foi possível ver que não foi detectada a presença de GP64 nas VLPs 
produzidas a partir de infecção de células Sf9 com o vírus vGAGHIV-1 GP64 null. Assim, foi demonstrada a eficácia da técnica na produção de VLPs de HIV-1 livres de GP64.

Vale ressaltar que pela primeira vez, BVs ou proteínas baculovirais, não foram detectadas em uma amostra de VLPs purificadas a partir do sistema baculovírus de expressão e que esse pode ser o primeiro passo para o desenvolvimento de uma técnica pioneira para produção de VLPs "GP64 free" utilizando sistema baculovírus de expressão.

\section{Referências Bibliográficas}

AIRENNE, K. J.; MAKKONEN, K. E.; MAHONEN, A. J.; YLA-HERTTUALA, S. In vivo application and tracking of baculovirus. Current Gene Therapy. v. 10, p.187-94, 2010.

AKEY, D. L.; BROWN, W. C.; DUTTA, S.; KONWERSKI, J.; JOSE, J.; JURKIW, T. J.; DELPROPOSTO, J.; OGATA, G. M.; SKINIOTIS, G.; KUHN, R. J.; SMITH, J. L. Flavivirus NS1 Structures Reveal Surfaces for Associations with Membranes and the Immune System. Science. v. 343, p. 881-885, 2014.

ALCON, S.; TALARMIN, A.; DEBRUYNE, M.; FALCONAR, A.; DEUBEL, V. Enzyme-linked immunosorbent assay specific to Dengue virus type 1 nonstructural protein NS1 reveals circulation of the antigen in the blood during the acute phase of disease in patients experiencing primary or secondary infections. Journal of Clinical Microbiology. v. 40, p.376-381, 2002.

ALLEN G. E. \& KNELL J. D. A nuclear polyhedrosis virus of Anticarsia gemmatalis: I. ultrastructure, replication, and pathogenicity. Florida Entomologist. v. 60, p. 233-240, 1977. 
ALONSO-PADILLA, J.; DE OYA, N. J.; BLÁZQUEZ, A. B.; ESCRIBANO-ROMERO, E.; ESCRIBANO, J. M.; SAIZ, J. C. Recombinant West Nile virus envelope protein E and domain III expressed in insect larvae protects mice against West Nile disease. Vaccine. v. 29, p.1830-1835, 2011.

APTE-SENGUPTA, S.; SIROHI, D.; KUHN, R. J. Coupling of replication and assembly in flaviviruses. Current Opinion in Virology. v. 9, p.134-142, 2014.

ARDISSON-ARAÚJO, D. M.; ROCHA, J. R.; DA COSTA, M. H.; BOCCA, A. L.; DUSI, A. N.; DE OLIVEIRA RESENDE, R.; RIBEIRO. B. M. A baculovirus-mediated strategy for full-length plant virus coat protein expression and purification. Virology Journal. v. 10, p. 262, 2013.

ASSENBERG, R.; MASTRANGELO, E.; WALTER, T. S.; VERMA, A.; MILANI, M.; OWENS, R. J.; STUART, D. I.; GRIMES, J. M.; MANCINI, E. J. Crystal Structure of a Novel Conformational State of the Flavivirus NS3 Protein: Implications for Polyprotein Processing and Viral Replication. Journal of Virology. v. 83, p. 12895-12906, 2009.

AVIRUTNAN, P.; PUNYADEE， N.; NOISAKRAN， S.; KOMOLTRI， C.; THIEMMECA, S.; AUETHAVORNANAN, K.; JAIRUNGSR, A.; KANLAYA, R.; TANGTHAWORNCHAIKUL, N. Vascular leakage in severe Dengue virus infections: a potential role for the non-structural viral protein NS1 and complement. The Journal of Infectious Diseases. v. 193, p. 1078-1088, 2006.

BAC-TO-BAC@ BACULOVIRUS EXPRESSION SYSTEM MANUAL. Disponível em: https://tools.thermofisher.com/content/sfs/manuals/bactobac_man.pdf. Acesso em: 28 de abril de 2016.

BEASLEY, D. W.; MCAULEY, A. J.; BENTE, D. A. Yellow fever virus: genetic and phenotypic diversity and implications for detection, prevention and therapy. Antiviral Research. v. 115, p. 48-70, 2015. 
BLISSARD, G. W.; WENZ, J. R. Baculovirus gp64 envelope glycoprotein is sufficient to mediate pH-dependent membrane fusion. Journal of Virology. v. 66, p. 6829-35, 1992.

BRACONI, C. T.; ARDISSON-ARAÚJO, D. M.; PAES LEME, A. F.; OLIVEIRA, J. V.; PAULETTI, B. A.; GARCIA-MARUNIAK, A.; RIBEIRO, B. M.; MARUNIAK, J. E.; ZANOTTO, P. M. Proteomic analyses of baculovirus Anticarsia gemmatalis multiple nucleopolyhedrovirus budded and occluded virus. Journal of General Virology. v. 95, p. 980-9, 2014.

BRENNER, S. \& HORNE, R. W. A negative staining method for high resolution electron microscopy of viruses. Biochimica et Biophysica Acta. v. 34, p. 103-10, 1959.

BRIGGS, J. A.; WILK, T.; WELKER, R.; KRÄUSSLICH, H. G.; FULLER, S. D. Structural organization of authentic, mature HIV-1 virions and cores. The EMBO journal. v. 22, p. 1707-15, 2003.

BRINTON, M. A. The molecular biology of West Nile virus: A new invader of the western hemisphere. Annual Review of Microbiology. v. 56, p. 371-402, 2002.

BUCHBINDER, S. P.; KATZ, M. H.; HESSOL, N. A.; O'MALLEY, P. M.; HOLMBERG, S. D. "Long-term HIV-1 infection without immunologic progression". AIDS. v. 8, p. 1123-8, 1994.

CASTRO, M. E. B.; SOUZA, M. L.; SIHLER, W.; RODRIGUES, J. C. M.; RIBEIRO, B. M. Biologia Molecular de baculovírus e seu uso no controle biológico de pragas no Brasil. Pesquisa Agropecuária Brasileira. v. 34, p. 1733-1761, 1999.

CHAMBERS, T. J.; HAHN, C. S.; GALLER, R.; RICE, C. M. Flavivirus: genome organization, expression, and replication. Annual Review of Microbiology. v. 44, p. 64960, 1990.

CHAMBERS, T. J.; MCCOURT, D. W.; RICE, C. M. Yellow fever virus proteins NS2A, NS2B, and NS4B: identification and partial N-terminal amino acid sequence analysis. Virology. v. 169, p. 100-109, 1989. 
CHANG, J. H.; CHOI, J. Y.; JIN, B. R.; ROH, J. Y.; OLSZEWSKI, J. A.; SEO, S. J.; O’REILLY, D. R.; JE, Y. H. An improved baculovirus insecticide producing occlusion bodies that contain Bacillus thuringiensis insect toxin. Journal of Invertebrate Pathology. v. 84 , p. $30-37,2003$.

CHATEL-CHAIX, L.; FISCHL, W.; SCATURRO, P.; CORTESE, M.; KALLIS, S.; BARTENSCHLAGER, M.; FISCHER, B.; BARTENSCHLAGER, R. A Combined Genetic-Proteomic Approach Identifies Residues within Dengue Virus NS4B Critical for Interaction with NS3 and Viral Replication. Journal of Virology. v. 89, p. 7170-86, 2015.

CHERNIN, L. R.; SWENDER, D.; HOSTOFFER, R. W. JR. Cracking the shell on egghypersensitive patients and egg-containing vaccines. The Journal of the American Osteopathic Association. v. 10, p. 5-6, 2011.

CHU, J. J.; RAJAMANONMANI, R.; LI, J.; BHUVANAKANTHAM, R.; LESCAR, J.; NG, M. L. Inhibition of West Nile virus entry by using a recombinant domain III from the envelope glycoprotein. Journal of General Virology. v. 86, p. 405-412, 2005.

CHUA, A. J.; VITURET, C.; TAN, M. L.; GONZALEZ, G.; BOULANGER, P.; NG, M. L.; HONG, S. S. A novel platform for virus-like particle-display of flaviviral envelope domain III: induction of Dengue and West Nile virus neutralizing antibodies. Virology Journal. v. 10, p. 129, 2013.

COCONI-LINARES, N.; ORTEGA-DÁVILA, E.; LÓPEZ-GONZÁLEZ, M.; GARCÍAMACHORRO, J.; GARCÍA-CORDERO, J.; STEINMAN, R. M.; CEDILLO-BARRÓN, L.; GÓMEZ-LIM, M. A. Targeting of envelope domain III protein of DENV type 2 to DEC-205 receptor elicits neutralizing antibodies in mice. Vaccine. v. 31, p. 2366-2371, 2013.

DAVIDSON, A. D. Chapter 2. New insights into flavivirus nonstructural protein 5. Advances in Virus Research. v. 74, p. 41-101, 2009. 
FAN, J.; LIU, Y.; XIE, X.; ZHANG, B.; YUAN, Z. Inhibition of Japanese encephalitis virus infection by flavivirus recombinant E protein domain III. Virologica Sinica. v. 28, p.152-160, 2013.

FERNANDES, F.; TEIXEIRA, A. P.; CARINHAS, N.; CARRONDO, M. J.; ALVES, P. M. Insect cells as a production platform of complex virus-like particles. Expert Review of Vaccines. v. 12, p. 225-36, 2013.

FERNANDEZ-GARCIA, M. D.; MAZZON, M.; JACOBS, M.; AMARA, A. Pathogenesis of flavivirus infections: using and abusing the host cell. Cell host \& Microbe. v. 5, p. 318-28, 2009.

FERREIRA, B. C.; MELO, F. L.; SOUZA, M. L.; MOSCARDI, F.; BÁO, S. N.; RIBEIRO, B. M. High genetic stability of peroral infection factors from Anticarsia gemmatalis MNPV over 20 years of sampling. Journal of Invertebrate Pathology. v. 118, p. 66-70, 2014.

FIELDS, B. N.; HOWLEY, P. M.; GRIFFIN, D. E. Fields Virology, fourth ed. 2007.

FLAMAND, M.; MEGRET, F.; MATHIEU, M.; LEPAULT, J.; REY, F. A.; DEUBEL, V. Dengue-1 nonstructural glycoprotein NS1 is secreted from mammalian cells as a soluble hexamer in a glycosylation-dependent fashion. Journal of Virology. v. 73, p. 6104-6110, 1999.

FONTANA, D.; ETCHEVERRIGARAY, M.; KRATJE, R.; PRIETO, C. Development of Rabies Virus-Like Particles for Vaccine Applications: Production, Characterization, and Protection Studies. Methods in Molecular Biology. v. 1403, p. 155-66, 2016.

FREED, E. O. HIV-1 Gag Proteins: Diverse Functions in the Virus Life Cycle. v. 521, p. $1-15,1998$. 
GALLER, R.; PUGACHEV, K. V.; SANTOS, C. L. S.; OCHRAN, S. W.; JABOR, A. V.; RODRIGUES, S. G.; MARCHEVSKY, R. S.; FREIRE, M. S.; ALMEIDA, L. F. C.; CRUZ, A. C. R.; YAMAMURA, A. M. Y.; ROCCO, I. M.; ROSA, E. S. T.; SOUZA, L. T. M.; VASCONCELOS, P. F. C.; GUIRAKHOO, F.; MONATH, T. P. Phenotypic and molecular analyses of yellow fever 17DD vaccine viruses associated with serious adverse events in Brazil. Virology. v. 290, p.309-319, 2001.

GHEYSEN, D.; JACOBS, E.; DE FORESTA, F.; THIRIART, C.; FRANCOTTE, M.; THINES, D.; DE WILDE, M. Assembly and release of HIV-1 precursor Pr55gag viruslike particles from recombinant baculovirus-infected insect cells. Cell. v. 59, p. 103-12, 1989.

GRABHERR, R. \& ERNST, W. Baculovirus for eukaryotic protein display. Current Gene Therapy. v. 10, p. 195-200, 2010.

GRANADOS, R .R.; GUOXUM. L.; DERKSEN, A. C. G.; McKENNA, K. A. A new insect cell line from Trichoplusia ni (BTI-Tn-5B1-4) susceptible to Trichoplusia ni single enveloped nuclear polyhedrosis virus. Journal of Invertebrate Pathology. v. 64, p. 260266, 1994.

GUERBOIS, M.; MORIS, A.; COMBREDET, C.; NAJBURG, V.; RUFFIÉ, C.; FÉVRIER, M.; CAYET, N.; BRANDLER, S.; SCHWARTZ, O.; TANGY, F. Live attenuated measles vaccine expressing HIV-1 Gag virus like particles covered with gp160DeltaV1V2 is strongly immunogenic. Virology. v. 388, p. 191-203, 2009.

HAASE, S.; SCIOCCO-CAP, A.; ROMANOWSKI, V. Baculovirus insecticides in Latin America: historical overview, current status and future perspectives. Viruses. v. 7, p. 2230-67, 2015.

HEINZ, F. X. \& ALLISON, S. L. Flavivirus structure and membrane fusion. Advances in Virus Research. v. 59, p. 63-97, 2003.

HEINZ, F. X. \& STIASNY, K. Flaviviruses and their antigenic structure. Journal of Clinical Virology. v.55, p. 289-95, 2012. 
HERNIOU, E. A.; ARIF, B. M.; BECNEL, J. J.; BLISSARD, G. W.; BONNING, B.; HARRISON, R.; JEHLE, J. A.; THEILMANN, D. A.; VLAK, J. M. BACULOVIRIDAE. IN: KING A. M. Q.; ADAMS, M. J.; CARSTENS, E. B.; LEFKOWITZ, E.J. Editors. Virus Taxonomy: Classification and Nomenclature of Viruses: Ninth Report of the International Committee on Taxonomy of Viruses. Elsevier Academic Press: San Diego, CA, USA, p. 163-173, 2012.

HOPKINS, R. \& ESPOSITO, D. A rapid method for titrating baculovirus stocks using the Sf-9 Easy Titer cell line. Biotechniques. v. 47, p. 785-788, 2009.

HORTON, H. M. \& BURAND, J. P. Saturable attachment sites for polyhedron-derived baculovirus on insect cells and evidence for entry via direct membrane fusion. Journal of Virology. v. 67, p. 1860-8, 1993.

HU, Y. C., BENTLEY, W. E., EDWARDS, G. H.; VAKHARIA, V. N. Chimeric infectious bursal disease virus-like particles expressed in insect cells and purified by immobilized metal affinity chromatography. Biotechnology and Bioengineering. v. 63, p. 721-729, 1999.

JE, Y. H.; JIN, B. R.; PARK, H. W.; ROH, J. Y.; CHANG, J. H.; SEO, S. J.; OLSZEWSKI, J. A.; O'REILLY, D. R.; KANG, S. K. Baculovirus expression vectors that incorporate the foreign protein into viral occlusion bodies. Biotechniques. v. 34, p. 81-7, 2003.

JEHLE, J. A.; BLISSARD, G. W.; BONNING, B. C. On the classification and nomenclature of baculoviruses: a proposal for revision. Archives of Virology. v. 151, p. 1257-1266, 2006.

JOUVENET, N.; BIENIASZ, P. D.; SIMON, S. M. Imaging the biogenesis of individual HIV-1 virions in live cells. Nature. v. 454, p. 236-240, 2008. 
KATAOKA, C.; KANAME, Y.; TAGUWA, S.; ABE, T.; FUKUHARA, T.; TANI, H.; MORIISHI, K.; MATSUURA, Y. Baculovirus GP64-Mediated Entry into Mammalian Cells. Journal of Virology. v. 86, p. 2610-2620, 2012.

KENNEDY R. B.; OVSYANNIKOVA, I. G.; JACOBSON, R. M.; POLAND, G. A. The immunology of smallpox vaccines. Current Opinion in Imunology. v. 21, p. 314-320, 2009.

KOST, T. A.; CONDREAY, J. P. Recombinant baculoviroses as mammalian cell genedelivery vectors. Trends in Biotechnology. v. 20, p. 173-80, 2002.

KOST, T. A.; CONDREAY, J. P.; JARVIS, D. L. Baculovirus as versatile vectors for protein expression in insect and mammalian cells. Nature Biotechnology. v. 23, p. 567$75,2005$.

KU, P. I.; MILLER, A. K.; BALLEW, J.; SANDRIN, V.; ADLER, F. R.; SAFFARIAN, S. Identification of pauses during formation of HIV-1 virus like particles. Biophysical Journal. v. 105, p. 2262-72, 2013.

LAEMMLI, U. K. Cleavage of structural proteins during assembly of the head of bacteriophage T4. Nature. v. 227, p. 680-685, 1970.

LI, Z. \& BLISSARD, G. W. The Autographa californica Multicapsid Nucleopolyhedrovirus GP64 Protein: Analysis of Transmembrane Domain Length and Sequence Requirements. Journal of Virology. v. 83, p. 4447-4461, 2009.

LIM, S. P.; NOBLE, C. G.; SHI, P. Y. The dengue virus NS5 protein as a target for drug discovery. Antiviral Research. v. 119, p. 57-67, 2015.

LINDENBACH, B. D. \& RICE, C. M. trans-Complementation of yellow fever virus NS1 reveals a role in early RNA replication. Journal of Virology. v.71, p.9608-9617, 1997.

LINDENBACH, B. D.; THIEL, H-J.; RICE, C. M. Flaviviridae: The viruses and their replication. In: D. M. Knipe and P. M. Howley, Eds. Fields Virology, 5th Edition. Philadelphia: Lippincott-Raven Publishers, p. 1101-1152, 2007. 
LIU, F.; WU, X.; LI, L.; LIU, Z.; WANG, Z. Use of baculovirus expression system for generation of virus-like particles: Successes and challenges. Protein Expression and Purification. v. 90, p. 104-116, 2013.

LIU, Y.; LIU, H.; KIM, B. O.; GATTONE, V. H.; LI, J.; NATH, A.; BLUM, J.; HE, J. J. CD4-independent infection of astrocytes by human immunodefi ciency virus type 1: requirement for the human mannose receptor. Journal of Virology. v. 78, p. 4120-33, 2004.

LUO, W. Y.; LIN, S. Y.; LO, K. W.; LU, C. H.; HUNG, C. L.; CHEN, C. Y.; CHANG, C. C.; HU, Y. C. Adaptive Immune Responses Elicited by Baculovirus and Impacts on Subsequent Transgene Expression In Vivo. Journal of Virology. v. 87, p. 4965-4973, 2013.

LUNG, O. Y.; CRUZ-ALVAREZ, M.; BLISSARD, G. W. Ac23, an envelope fusion protein homolog in the baculovirus Autographa californica multicapsid nucleopolyhedrovirus, is a viral pathogenicity factor. Journal of Virology. v. 77, p. 328$39,2003$.

LYNCH, A.; MEYERS, A. E.; WILLIAMSON, A. L.; RYBICKI, E. P. Stability studies of HIV-1 Pr55gag virus-like particles made in insect cells after storage in various formulation media. Virology Journal. v. 18, p. 210, 2012.

MAARTENS, G.; CELUM, C.; LEWIN, S. R. HIV infection: epidemiology, pathogenesis, treatment, and prevention. Lancet. v. 384, p. 258-71, 2014.

MACKENZIE, J. S.; GUBLER, D. J.; PETERSEN, L. R. Emerging flaviviruses: the spread and resurgence of Japanese encephalitis, West Nile and dengue viruses. Nature Medicine. v. 10, p. s98-109, 2004.

MÄKELÄ, A. R. \& OKER-BLOM, C. Baculovirus display: a multifunctional technology for gene delivery and eukaryotic library development. Advances in Virus Research. v. 68, p. 91-112, 2006. 
MARTINA, B. E.; KORAKA, P.; VAN DEN DOEL, P.; VAN AMERONGEN, G.; RIMMELZWAAN, G. F.; OSTERHAUS, A. D. Immunization with West Nile virus envelope domain III protects mice against lethal infection with homologous and heterologous virus. Vaccine. v. 26, p. 153-7, 2008.

MARTINA, B. E.; VAN DEN DOEL, P.; KORAKA, P.; VAN AMERONGEN, G.; SPOHN, G.; A recombinant influenza A virus expressing domain III of West Nile virus induces protective immune responses against influenza and West Nile virus. PLoS One. v. 6, p. e18995, 2011.

MCLEAN, J. E.; WUDZINSKA, A.; DATAN, E.; QUAGLINO, D.; ZAKERI, Z. Flavivirus NS4A-induced autophagy protects cells against death and enhances virus replication. The Journal of Biological Chemistry. v. 286, p. 22147-22159, 2011.

MILLER, L. K.; TRIMARCHI, R. E.; BROWNE, D.; PENNOCK, G. D. A temperaturesensitive mutant of the baculovirus Autographa californica nuclear polyhedrosis virus defective in an early function required for further gene expression. Virology. v.126, p. 376-80, 1983.

MINISTÉRIO DA SAÚDE. Doenças infecciosas e parasitárias: Guia De Bolso, BrasíliaDF. v. 1, $3^{\mathrm{a}}$ edição, p. 151, 2004.

MINISTÉRIO DA SAÚDE. DST, AIDS, HEPATITES VIRAIS. Disponível em: http://www.aids.gov.br/. Acesso em: 26 de nov. 2015.

MINISTÉRIO DA SAÚDE. SECRETARIA DE VIGILÂNCIA EM SAÚDE. Boletim Epidemiológico $n^{\circ} 23$, v. 46, 2015.

MONATH, T. P. Yellow fever: an update. Lancet Infectious Diseases. v.1, p.11-20, 2001. MONATH, T. P. Yellow fever vaccine. Expert Review of Vaccines. v. 4, p. 553-74, 2005. MONATH, T.; CETRON, M. S.; TEUWEN, D. E. Yellow fever vaccine. In: Plotkin, S. A.; Orenstein, W. A.; Offit, P. A. Vaccines. 5th ed. Philadelphia, PA: Saunders Elsevier, p.959-1055, 2008. 
MONATH, T. P. \& VASCONCELOS, P. F. Yellow fever. Journal of Clinical Virology. v. 60, p. 160-73, 2015.

MONSMA, S. A.; OOMENS, A. G.; BLISSARD, G. W. The GP64 envelope fusion protein is an essential baculovirus protein required for cell-to-cell transmission of infection. Journal of Virology. v. 70, p. 4607-4616, 1996.

MONTOR, W. R. \& SOGAYAR, M. C. Insetos como biofábricas de proteínas humanas. Ciência hoje, Biotecnologia. v. 33, p. 16-23, 2003.

MOSCARDI, F.; DE SOUZA, M. L.; DE CASTRO, M. E. B.; MOSCARDI, M. L.; SZEWCZYK B. Baculovirus pesticides: present state and future perspectives. Microbes and Microbial Technology, p. 415-445, 2011.

MOSCARDI, F. \& SOSA-GÓMEZ, D. R. Microbial control of insect pests of soybeans. In: Lacey L.A., Kaya H.K., editors. Field Manual of Techniques in Invertebrate Pathology: Application and Evaluation of Pathogens for Control of Insects and Other Invertebrate Pests. Springer. p. 447-466, 2000.

MUGO, N. R.; HEFFRON, R.; DONNELL, D.; WALD, A.; WERE, E. O.; REES, H.; CELUM, C,; KIARIE, J. N.; COHEN, C. R. KAYINTEKORE, K.; BAETEN, J. M.; PARTNERS IN PREVENTION HSV/HIV TRANSMISSION STUDY TEAM. Increased risk of HIV-1 transmission in pregnancy: a prospective study among African HIV-1-serodiscordant couples. AIDS. v. 25, p. 1887-95, 2011.

MULLER, D. A. \& YOUNG, P. R. The flavivirus NS1 protein: Molecular and structural biology, immunology, role in pathogenesis and application as a diagnostic Biomarker. Antiviral Research. v. 98, p. 192-208, 2013.

MUTEBI, J. P. \& BARRETT, A. D. The epidemiology of yellow fever in Africa. Microbes and Infection. v. 4, p. 1459-68, 2002.

NASKALSKA, A. \& PYRĆ, K. Virus Like Particles as Immunogens and Universal Nanocarriers. Polish Journal of Microbiology. v. 64, p. 3-13. 2015. 
NEMÉSIO, H.; PALOMARES-JEREZ, F.; VILLALAÍN, J. NS4A and NS4B proteins from dengue virus: membranotropic regions. Biochimica et Biophysica Acta. v. 1818, p. 2818-2830, 2012.

NYAMWEYA, S.; HEGEDUS, A.; JAYE, A.; ROWLAND-JONES, S.; FLANAGAN, K. L.; MACALLAN, D. C. Comparing HIV-1 and HIV-2 infection: Lessons for viral immunopathogenesis. Reviews in Medical Virology. v. 23, p. 221-40, 2013.

OKER- BLOM, C.; AIRENNE, K. J.; GRABHERR, R. Baculovirus display strategies: Emerging tools for eukaryotic libraries and gene delivery. Briefings in Functional genomics \& proteomics. v. 2, p. 244-53, 2003.

OOMENS, A. G. \& BLISSARD, G. W. Requirement for GP64 to drive efficient budding of Autographa californica multicapsid nucleopolyhedrovirus. Virology. v. 254, p. 297314, 1999.

O’REILLY, D. R.; MILLER, L. K.; LUCKOW, V. A. Baculovirus Expression Vectors: A Laboratory Manual. New York: W.H. Freeman and Company, 1992.

PEARSON, M. N.; GROTEN, C.; ROHRMANN, G. F. Identification of the Lymantria dispar nucleopolyhedrovirus envelope fusion protein provides evidence for a phylogenetic division of the Baculoviridae. Journal of Virology. v. 74, p. 6126-6131, 2000.

PEI-I, K.; MILLER, A. K.; BALLEW, J.; SANDRIN, V.; ADLER, F.A.; SAFFARIAN, S. Identification of Pauses during Formation of HIV-1Virus Like Particles. Biophysical Journal. v. 105, p. 2262-2272, 2013.

PERERA-LECOIN, M.; MEERTENS, L.; CARNEC, X.; AMARA, A. Flavivirus entry receptors: an update. Viruses. v. 30, p. 69-88, 2013.

PILLAY, S.; MEYERS, A.; WILLIAMSON, A. L.; RYBICKI, E. P. Optimization of chimeric HIV-1 virus-like particle production in a baculovirus-insect cell expression system. Biotechnology Progress. v. 25, p. 1153-60, 2009. 
PLONSKY, I.; CHO, M. S.; OOMENS, A. G.; BLISSARD, G.; ZIMMERBERG, J. An analysis of the role of the target membrane on the Gp64-induced fusion pore. Virology. v. 253 , p. $65-76,1999$.

REED, L. J. \& MUENCH, H. A simple method of estimating fifty percent endpoints. The American Journal of Tropical Medicine and Hygiene. v. 27, p. 493-497, 1938.

REY, F. A.; HEINZ, F. X.; MANDL, C.; KUNZ, C.; HARRISON, S. C. The envelope glycoprotein from tick-borne encephalitis virus at 2 A resolution. Nature. v. 25, p. 2918, 1995.

RIBEIRO, B. M.; MORGADO, F. S.; ARDISSON - ARAUJO, D. M. P.; SILVA, L. A.; CRUZ, F. S. P.; CHAVES, L. C. S.; QUIRINO, M. S.; ANDRADE, M. S.; CORREA, R. F. T. Baculovírus para expressão de proteínas recombinantes em células de inseto. In: Rodrigo R. Resende. (Org.). Biotecnologia Aplicada à Saúde - Volume 2. 1ed. São Paulo: Editora Blucher. v. 2, p. 255-306, 2015.

RICE, C. M. Flaviviridae: the viruses and their replication. In: Fields, B. N.; Knipe, D. Howley, M. P. M., eds. Fields virology. 3 ed. Philadelphia PA: Lippincott-Raven Publishers, v. 1, p. 931-960, 1996.

ROHRMANN, G. F. Baculovirus Molecular Biology: Third Edition. Bethesda (MD): National Center for Biotechnology Information (US), 2013. Disponível em: http://www.ncbi.nlm.nih.gov/books/NBK114593. Acesso em: 26 de nov. 2015.

ROLLIE, J. C.; PASSARELLI, A. L. Baculoviruses: Sophisticated Pathogens of Insects. PLOS Pathogens. v. 9, e1003729, 2013.

RUBENS, M.; RAMAMOORTHY, V.; SAXENA, A.; SHEHADEH, N.; AND APPUNNI, S. HIV Vaccine: Recent Advances, Current Roadblocks, and Future Directions. Jornal of Immunology Research. v. 2015, 2015. 
RUEDA, P.; FOMINAYA, J.; LANGEVELD, J. P.; BRUSCHKE, C.; VELA, C.; CASAL, J. I. Effect of different baculovirus inactivation procedures on the integrity and immunogenicity of porcine parvovirus-like particles. Vaccine. v. 19, p. 726-734, 2000.

SAHDEV, S.; KHATTAR, S. K.; SAINI, K. S. Production of active eukaryotic proteins through bacterial expression systems: a review of the existing biotechnology strategies. Molecular and Cellular Biochemistry. v. 307, p. 249-64, 2008.

SAMBROOK, J.; FRITSH, E. F.; MANIATIS, T. Molecular Cloning: a laboratory manual. Cold Spring Harbor Laboratory Press, 1989.

SAMSA, M. M.; MONDOTTE, J. A.; IGLESIAS, N. G.; MIRANDA, I. A.; LIMA, G. B.; POIAN, A. T.; BOZZA, P. T.; GAMARNIK, A. V. Dengue Virus Capsid Protein Usurps Lipid Droplets for Viral Particle Formation. PLOS Pathogens. v. 5, e 1000632 2009.

SANTOS, N. S. O.; ROMANOS, M. T. V.; WIGG, M. D. Introdução á Virologia Humana. Editora Guanabara-Koogan, 2002.

SCHLESINGER, J. J.; BRANDRISS, M. W.; PUTNAK, J. R.; WALSH, E. E. Cell surface expression of yellow fever virus non-structural glycoprotein NS1: consequences of interaction with antibody. Journal of General Virology. v. 71, p. 593-9, 1990.

SCHNEIDER, M. F.; GANGE, S. J.; WILLIAMS, C. M.; ANASTOS, K.; GREENBLATT, R. M.; KINGSLEY, L.; DETELS, R.; MUNOZ, A. "Patterns of the hazard of death after AIDS through the evolution of antiretroviral therapy: 1984-2004". AIDS. v. 19, p. 2009-18, 2005.

SCHWARZ, T. F. Clinical update of the AS04-Adjuvanted human Papillomavirus-16/18 cervical cancer vaccine, cervarix. Advances in Therapy. v. 26, p. 983-998, 2009.

SILVA, F. G.; SILVA, S. J. S.; ROCCO, I. M.; SILVEIRA, V. R.; SUZUKI, A.; KATZ, G.; BISORDI, I. Avaliação de kits comerciais para detecção de antígenos NS1-dengue São Paulo. Bepa. v. 8, p. 14-26, 2011. 
STADLER, K.; ALLISON, S. L.; SCHALICH, J.; HEINZ, F. X. Proteolytic activation of tick-borne encephalitis virus by furin. Journal of virology. v. 71, p. 8475-8481, 1997.

STIASNY, K. \& HEINZ, F. X. Flavivirus membrane fusion. Journal of General Virology. v. 87, p. 2755-2766, 2006.

STIASNY, K.; FRITZ, R.; PANGERL, K.; HEINZ, F. X. Molecular mechanisms of flavivirus membrane fusion. Amino acids. v. 41, p. 1159-63, 2009.

SUKOSD, S.; ANDERSEN, E. S.; SEEMANN, S. E.; JENSEN, M. K.; HANSEN, M.; GORODKIN, J.; KJEMS, J. Full-length RNA structure prediction of the HIV-1 genome reveals a conserved core domain. Nucleic acids research, 2015. Disponível em: http://nar.oxfordjournals.org/content/early/2015/10/15/. Acesso em: 26 de nov. 2015.

SUZUKI, Y. \& SUZUKI, Y. Gene Regulatable Lentiviral Vector System. In: Viral gene Therapy, 2015. Disponível em: http://www.intechopen.com/books/viral-genetherapy/gene-regulatable-lentiviral-vector-system. Acesso em: 26 de novembro de 2015.

THEVES, G. [Smallpox: an historical review]. Bulletin de la Societe des Sciences Medicales du Grand-Duche de Luxembourg. v. 134, p. 31-51, 1997.

THOMPSON, C. M.; AUCOIN, M. G.; KAMEN, A. A. Production of Virus-Like Particles for Vaccination. Methods in molecular biology. v. 1350, p. 299-315, 2016.

UMAREDDY, I.; PLUQUET, O.; WANG, Q. Y.; VASUDEVAN, S. G.; CHEVET, E.; GU, F. Dengue virus serotype infection specifies the activation of the unfolded protein response. Virology Journal. v. 4, p. 91, 2007.

UNAIDS. MDG 6: 15 YEARS, 15 LESSONS OF HOPE FROM THE AIDS RESPONSE, 2014 GLOBAL STATISTICS, FACT SHEET, 2015.

VALLEY-OMAR, Z.; MEYERS, A. E.; SHEPHARD, E. G.; WILLIAMSON, A. L.; RYBICKI, E. P. Abrogation of contaminating RNA activity in HIV-1 Gag VLPs. Virology Journal. v. 8, p. 462, 2011. 
VAN ZYL, A. R. \& HITZEROTH, I. I. Purification of Virus-Like Particles (VLPs) from Plants. Methods in Molecular Biology. v. 1404, p. 569-79, 2016.

VASCONCELOS, P. F. C. Febre amarela. Revista da Sociedade Brasileira de Medicina Tropical. v. 36, p. 275-293, 2003.

VAUGHN, J. L.; GOODWIN, R. H.; TOMPKINS, G. J.; MCCAWLEY, P. The establishment of two cell lines from the insect Spodoptera frugiperda (Lepidoptera; Noctuidae). In Vitro. v. 13, p. 213-7, 1977.

VISCIANO, M. L.; DIOMEDE, L.; TAGLIAMONTE, M.; TORNESELLO, M. L.; ASTI, V.; BOMSEL, M.; BUONAGURO, F. M.; LOPALCO. L.; BUONAGURO. L. Generation of HIV-1 Virus-Like Particles expressing different HIV-1 glycoproteins. Vaccine. v. 31, p. 4903-12, 2011.

VOGT, V. M. Retroviral Virions and Genomes. In: Coffin JM, Hughes SH, Varmus HE, editors. Retroviruses. Cold Spring Harbor (NY): Cold Spring Harbor Laboratory Press, 1997.

VOLK, D. E.; MAY, F. J.; GANDHAM, S. H.; ANDERSON, A.; VON LINDERN, J. J.; BEASLEY, D. W.; BARRET, A. D.; GORENSTEIN, D. G. Structure of Yellow Fever Virus Envelope Protein Domain III. Virology. v. 394, p.12-8, 2009.

VRATSKIKH, O.; STIASNY, K.; ZLATKOVIC, J.; TSOUCHNIKAS, G.; JARMER, J.; KARRER, U.; ROGGENDORF, M.; ROGGENDORF, H.; ALLWINN, R.; HEINZ, F. $\mathrm{X}$. Dissection of antibody specificities induced by yellow fever vaccination. PLOS Pathogens. v. 9, e1003458, 2013.

WAHOME, N.; COOPER, A.; THAPA, P.; CHOUDHARI, S.; GAO, F. P.; VOLKIN, D. B.; MIDDAUGH, C. R. Production of Well-Characterized Virus-like Particles in an Escherichia coli-Based Expression Platform for Preclinical Vaccine Assessments. Methods in Molecular Biology. v. 1404, p. 437-57, 2016. 
WANG, J. W. \& RODEN, R. B. Virus-like particles for the prevention of human papillomavirus-associated malignancies. Expert Review in Vaccines. v. 12, p. 129-41, 2013.

WHO. Yellow fever. 2014. Disponível em: http://www.who.int/csr/disease/yellowfev. Acesso: 26 de novembro de 2015.

WU, J.; BERA, A. K.; KUHN, R. J.; SMITH, J. L. Structure of the Flavivirus helicase: implications for catalytic activity, protein interactions, and proteolytic processing. Journal of Virology. v. 79, p. 10268-10277, 2005.

WU, C. \& WANG S. 2011. A pH-sensitive heparin-binding sequence from gp64 protein of baculovirus is important for binding to mammalian cells but not to Sf9 insect cells. Journal of Virology. v. 86, p. 484-91, 2012.

XU, X. G.; WANG, Z. S.; ZHANG, Q.; LI, Z. C.; ZHAO, H. N.; LI, W.; TONG, D. W.; LIU, H. J. Baculovirus surface display of E envelope glycoprotein of Japanese encephalitis virus and its immunogenicity of the displayed proteins in mouse and swine models. Vaccine. v. 29, p. 636-43, 2011.

YAMAJI, H. Suitability and perspectives on using recombinant insect cells for the production of virus-like particles. Applied Microbiology and Biotechnology. v. 98, p. 1963-70, 2014.

ZHANG, W.; CAO, S.; MARTIN, J. L.; MUElLER, J. D.; MANSKY, L. M. Morphology and ultrastructure of retrovirus particles. AIMS Biophysics. v. 2, p. 343-369, 2015.

ZOU, J.; XIE, X.; LEE, L. T.; CHANDRASEKARAN, R.; REYNAUD, A.; YAP, L.; WANG, Q. Y.; DONG, H.; KANG, C.; YUAN, Z.; LESCAR, J.; SHI, P. Y. Dimerization of flavivirus NS4B protein. Journal of Virology. v. 88, p. 3379-91, 2014. 
Anexos 
Manuscrito do artigo científico 


\title{
Efficient production of GP64 free HIV-1 Virus-Like Particles (VLPs) using baculovirus expression system
}

\author{
Chaves LCS ${ }^{1}$, Ribeiro BM¹ , Blissard GW². \\ ${ }^{1}$ Cell Biology Department, Institute of Biology, University of Brasilia, Brasilia - Distrito Federal - \\ Brazil. \\ ${ }^{2}$ Boyce Thompson Institute, Cornell University, Ithaca - New York - USA.
}

\section{Abstract}

"Virus like particles" (VLPs) are composed of viral capsid proteins that selfassemble into particles resembling natural virions. The baculovirus expression vector system (BEVS) is a powerful tool that has been widely used to produce VLPs in insect cells. However, purified VLPs samples from insect cells are known for being contaminated with baculovirus budded virus (BV) particles. Besides that, these VLPs can have some host insect proteins expressed on their surface. Since VLPs are usually produced for vaccine development, the contamination with other virus particles or immunogenic proteins is a concern. In this work, we showed that VLP and BV particles cannot be separated by ultracentrifugation in sucrose gradients. Thus, to block BV production during VLP assembly, a recombinant baculovirus containing the GAG HIV-1 gene but lacking the baculovirus gp64 gene (vGAGHIV-1 GP64 null) was constructed. This recombinant baculovirus was then used to infect Sf9 cells and shown to correctly produce HIV-1 VLPs without BVs particles. GP64 protein was not detected in these cells, confirming the correct deletion of the gp64 gene. Furthermore, the 
presence of GAG protein was detected and was possible to see HIV-1-derived VLPs produced from cells infected with this GP64 defective recombinant virus. Therefore, this work describes, for the first time, a new way of producing VLPs in insect cells without the contamination of baculovirus BV particles.

\section{Introduction}

VLPs ("Virus like particles") are protein structures that mimics viral particles and can be non-enveloped or enveloped by a membrane derived from a cell. Due to the lack of viral genomes, VLPs do not replicate and are infection-incompetent, which make them excellent models for studying viral structure and immune system activation during viral infections $\left({ }^{1,2}\right)$. They can also be used as alternative vaccines, delivery and surface display platforms $\left.{ }^{(3-5}\right)$. These particles are capable of inducing B and T cell-mediated immune responses as well as neutralizing antibody production. Besides the immune system activation ability, VLPs are safer and cheaper alternatives compared to live and/or attenuated vaccines $\left({ }^{6,7}\right)$. VLP based vaccines are already being commercialized worldwide, such as Engerix ${ }^{\circledR}$ - B (against the Hepatitis B virus) produced in yeast cells (Saccharomyces cerevisiae) and Cervarix ${ }^{\circledR}$ (against the Human Papiloma virus) produced in insect cells (BEVS) $\left(^{8}\right)$. The BEVS is a powerful eukaryotic expression system, capable of complex post-translational modifications in expressed recombinant proteins, which could be important for the correct selfassembly and release of VLPs, making this system a good alternative for different kinds of VLPs production (9-12). 
The assembly mechanism of VLPS depends of the type of the particle (enveloped or non-enveloped). The enveloped VLPs assembly depends on the capsid (or matrix) formation and then membrane enclosure for budding from a host cell membrane. Through this mechanism, enveloped VLPs can incorporate host proteins $\left({ }^{13}\right)$. That is the case of the baculovirus envelope protein GP64 that is expressed on the surface of insect cells during the baculovirus infection $\left({ }^{14}\right)$.

There are two types of virions produced during the baculovirus infection, the ODVs (Occlusion derived viruses) and BVs (Budded viruses). Both contain the same genome, but differ in morphogenesis, envelope composition and function within the viral infection cycle. The GP64 is a type I integral membrane glycoprotein that is on the surface of baculovirus BV particles. The GP64 protein is required for the entry and budding of these particles during the baculovirus infection cycle $\left({ }^{15-17}\right)$. The GP64 protein is an immunogenic protein able to trigger specific immune response in BALB/c mice $\left({ }^{18}\right)$. Some VLPs produced by BEVS are contaminated with GP64 during the particle assembly, which is the case of HIV-1 VLPs produced using this system $\left({ }^{19}\right)$. The HIV-1 gag open reading frame (ORF) encodes a polyprotein of $55 \mathrm{kDa}$ that is processed in a nonglycosylated matrix protein p17 (MA), capsid protein (CA), nucleoprotein P9 (NP) and a link protein p6. The myristoylation of the gag precursor (Pr55) is essential for its membrane location and assembly of the capsid protein on the surface of the cells (20-22). The Pr55 expression is sufficient to assembly VLPs that will bud from the cell membrane of the host cell. $\left({ }^{23,24}\right)$. 
Since VLPs can be used for vaccine development, cross-reactivity immune responses towards host proteins co-expressed on the VLPs, or with the whole baculovirus particle, could affect VLPs specificity and efficiency $\left({ }^{25}\right)$. Therefore, a system to produce VLPs free of baculovirus particles or host proteins contamination would be of great value for the development of improved vaccines.

In this work, recombinant baculoviruses containing the HIV-1 GAG gene with or without the baculovirus gp64 gene were constructed. These recombinant baculoviruses were then used to infect insect cells and VLPs and baculovirus BV particles were purified from supernatant of infected cells at late times postinfection (p.i). It was not possible to completely separate BVs and VLPs from supernatant of insect cells infected with the recombinant virus containing the GAG and the gp64 gene using ultracentrifugation in sucrose gradients. However, the recombinant virus lacking the gp64 gene produced VLPs without the contamination of BV particles. This work describes, for the first time, a way to produce VLPs without the contamination of baculovirus BV particles, which could be used for the development of improved VLP-based vaccines.

\section{Materials and methods}

Insect cells. Spodoptera frugiperda Sf9 cells $\left({ }^{26}\right)$ were maintained in suspension at $27^{\circ} \mathrm{C}$ and $100 \mathrm{rpm}$ in TC-100 insect medium (Gibco-BRL) supplemented with $10 \%$ of fetal bovine serum (FBS), $1 \%$ antibiotic/antimycotic (Invitrogen) and $0.1 \%$ (w/v) Pluronic F-68 (Gibco). Spodoptera frugiperda Sf9Op1D $\left({ }^{27}\right)$ and Sf9 - easy 
titration (ET) $\left({ }^{28}\right)$ cells were mantained as monolayers at $28^{\circ} \mathrm{C}$ in TC-100 (GibcoBRL) insect medium supplemented with $10 \%$ of fetal bovine serum (FBS) and $1 \%$ antibiotic/antimycotic (Invitrogen). The Sf9Op1D cells has the GP64 from Orgyia pseudotsugata multiple nucleopolyhedrovirus - OpMNPV expressed constitutively $\left({ }^{27}\right)$.

Wild type and recombinant viruses. The plasmid pFB-HIV-2gb containing the full-length HIV-1 Pr55Gag (Gag) gene under control of the polyhedrin promoter was kindly provided from Dr. V. Vogt (Cornell University) and used to construct the recombinant baculovirus vGAGHIV-1 using the Bac-to-Bac ${ }^{\circledR}$ "Baculovirus Expression System" kit (Invitrogen)(29). For the production of the recombinant baculovirus vGAGHIV-1 GP64 null we used the same system but with a DH10Bac bacteria cell having a bacmid with the chloramphenicol resistance gene (CAT Chloramphenicol acetyltransferase) interrupting the ORF of the gp64 gene $\left({ }^{27}\right)$. To propagate the AcMNPV WT virus (strain E2) $\left({ }^{30}\right)$ and the vGAGHIV-1 recombinant virus, Sf9 cells were infected (m.o.i 1) and $72 \mathrm{~h} \mathrm{p.i.,} \mathrm{the} \mathrm{supernatant}$ collected and titled. The same was done to propagate the vGAGHIV-1 GP64 null recombinant virus but using the Sf9Op1D cells.

Titration by end-point dilution assay. End-point dilution assays were set using Sf9-ET cells ${ }^{(28)}$ grown to $1 \times 10^{4}$ cells $/ \mathrm{ml}$ in TC-100 medium, in a 96-well plate format and incubated $2 \mathrm{~h}$ at $25^{\circ} \mathrm{C}$. Cells were infected with serial 10 -fold dilutions of tested samples and incubated for 3 days at $25^{\circ}$ C. At $3-7$ days p.i., the Sf9ET plate was scored by monitoring wells containing eGFP signal. The number of 
wells considered positive for infection in each dilution, was used to calculate the titration of the viruses using the method described in $\left.{ }^{(31}\right)$.

Fusion assay. Spodoptera frugiperda Sf901D cells were treated separately with two different solutions (1x PBS pH 5.1 or 6.2 ). After 5 min of incubation, the cells were washed twice and the TC-100 (pH 6.2, Gibco-BRL) insect medium supplemented with $10 \%$ of FBS was replaced. Cells were checked 5 min and $1 \mathrm{~h}$ after treatment and analyzed for fusion activity using an optical microscope (Axiovert 100, Zeiss).

VLPs production and purification. Sf9 cells were infected with AcMNPV WT virus, vGAGHIV-1 and vGAGHIV-1 GP64 null recombinant viruses at a multiplicity of infection (m.o.i.) of 1. For infection using AcMNPV WT virus or vGAGHIV-1 recombinant virus was used a density of $5 \times 10^{5}$ cells $/ \mathrm{ml}$ and for infection with vGAGHIV-1 GP64 null was used a density of $1 \times 10^{6} \mathrm{cells} / \mathrm{ml}$. After $72 \mathrm{~h}$ post infection (p.i.), the supernatant was collected and clarified by centrifugation at $2000 \times g$ for $5 \mathrm{~min}$ at $4^{\circ} \mathrm{C}$. The VLPs were pelleted from the supernatant by ultra-centrifugation at $150.000 \times g$ for $2 \mathrm{~h}$ through a $25 \%$ sucrose cushion (w/v) and resuspended in 1x PBS (100 mM Na2 $\mathrm{HPO}_{4}, 17 \mathrm{mM} \mathrm{KH}_{2} \mathrm{PO}_{4}$, $1,4 \mathrm{mM} \mathrm{NaCl}$ and $27 \mathrm{mM} \mathrm{KCl}$ ). The semi-purified VLPs were loaded on the top of a $30-60 \%(w / v)$ sucrose gradient and ultra-centrifuged at $150.000 \times g$ for $18 \mathrm{~h}$. Fractions of $600 \mu \mathrm{l}$ were collected throughout the gradient, placed in tubes with $900 \mu \mathrm{l}$ of $1 \times$ PBS and ultra-centrifuged at $130.000 \times g$ for $2 \mathrm{~h}$. The purified VLPs present in all fractions were resuspended in 2x Laemmli buffer $\left({ }^{32}\right)$ and incubated for 5 min at $95^{\circ} \mathrm{C}$ and stored at $-20^{\circ} \mathrm{C}$ for further analyses. 
VLPs analyses. The purified VLPs in all the fractions were analyzed by electrophoresis in a $12 \%$ SDS-PAGE gel $\left.{ }^{32}\right)$. After electrophoresis, the gel was stained with Comassie Brilliant Blue (40\% methanol, $10 \%$ acetic acid and $0.1 \%$ of Brilhant Blue Coomassie R-250) for $18 \mathrm{~h}$. The protein expression pattern of each fraction was analyzed using infrared detection by the Li-Cor Biosciences Odyssey Infrared Imaging System (Li-Cor Biosciences). Known concentrations of BSA $(0.88,0.44,0.22,0.11,0.05 \mathrm{mg} / \mathrm{ml})$ were applied on the gel aiming the construction of a standard BSA curve that was used for protein quantification using the same device. The samples containing the VLPs were used in another $12 \%$ SDS-PAGE gel and after electrophoresis, transferred to a Nitrocellulose membrane (GE Heathcare) for Western blot (WB) analysis. Membranes were blocked in $3 \%$ skimmed milk diluted in $1 \times$ PBS $1 \mathrm{~h}$ at RT or overnight at $4^{\circ} \mathrm{C}$. Blocked membranes were washed 3 times for 5 min with 1x PBS/0.05\% Tween buffer and, then incubated for $1 \mathrm{~h}$ at room temperature (RT) with the primary antibody (mouse monoclonal anti-GP64 AcV5 1:2000, rabbit polyclonal antiVP39 1:5000 and anti-GAG HIV-1 p24 (NIH AIDS Reagent Program) 1:10000. Membranes were washed 3 times for 5 min with $1 \times$ PBS/0.05\% Tween and treated with the alkaline phosphatase (AP) conjugated secondary antibody (antimouse IgG produced in goat - Sigma), 1:10000 diluted for $1 \mathrm{~h}$ at RT. After incubation, the membranes were washed 3 times for 5 min with 1x PBS/0.05\% Tween and the proteins detected by NBT/BCIP staining (Invitrogen) diluted in distilled water. 
Infected cells analyses. Sf9 cells $\left(5 \times 10^{5}\right.$ cells $\left./ \mathrm{ml}\right)$ were infected with all the viruses used in this work (m.o.i. 1) and at $72 \mathrm{~h}$ p.i. the cells were collected by centrifugation at $2000 \times g$ for $5 \mathrm{~min}$ at $4^{\circ} \mathrm{C}$. The cells were resuspended in $1 \mathrm{x}$ PBS buffer and mixed with the same volume of $2 x$ Laemmli buffer $\left({ }^{32}\right)$ and incubated for $5 \mathrm{~min}$ at $95^{\circ} \mathrm{C}$. The proteins in the sample separated by electrophoresis in a $12 \%$ SDS-PAGE gel. After electrophoresis, the samples in the gel were transferred to a Nitrocellulose membrane (GE Heathcare) for WB analysis using anti-VP39, anti-GP64 and Anti-GAG antibodies (same specifications used in the VLPs proteins analyses). The membrane containing AcMNPV, vGAGHIV-1 and vGAGHIV-1 GP64 null infected cell extract was tested with an antibody and shortly after development, the membrane was washed, blocked and incubated with the next antibody, overlying the same membrane with the three different antibodies (Anti-GP64, Anti-VP39 and Anti-GAG). The same experiment was performed using membranes incubated with each antibody individually.

Electron microscopy. Purified or semi-purified VLPs were placed for $30 \mathrm{~min}$ on glow-discharged carbon-coated grids. After incubation, the grids were washed 3 times with 1x PBS and negatively stained with PTA (phosphotungstic acid) $2 \%$ ${ }^{(33)}$ for 2 min and analyzed by transmission electron microscopy - TEM (JEOL 1011). For immunogold staining, Sf9 cells were infected (m.o.i 1) with AcMNPV WT virus, vGAGHIV-1 and vGAGHIV-1 GP64 null recombinant viruses. Seventy two $h$ p.i., the cells were collected by centrifugation at $2000 \times g$ for 5 min at $4^{\circ} \mathrm{C}$, washed in 1x PBS and fixed with 4\% paraformaldehyde, 0.5\% glutaraldehyde 
and $0.01 \%$ picric acid in $0.1 \mathrm{M}$ sodium cacodylate buffer $\mathrm{pH} 6.4$ with $5 \%$ sucrose. After fixation, cells were washed twice in $0.1 \mathrm{M}$ sodium cacodylate buffer $\mathrm{pH} 6.4$ followed by $1 \mathrm{~h}$ incubation with $50 \mathrm{mM}$ ammonium chloride. Samples were washed twice in distilled water and contrasted in block "overnight" with $2 \%$ uranyl acetate in the dark at $4^{\circ} \mathrm{C}$. The samples were washed again (twice) in distilled water and dehydrated in increasing concentrations of acetone (30-90\%) for 10 min. at each concentration. Finally, samples were embedded in LR gold resin and incubated for $72 \mathrm{~h}$ at $-20^{\circ} \mathrm{C}$ under ultraviolet light. Thin sections were obtained in an ultramicrotome (Leica EM UC7), placed on nickel grids and incubated in 80 $\mathrm{mM}$ ammonium chloride diluted in 1x PBS for $30 \mathrm{~min}$. The nickel grids containing the samples were incubated $1 \mathrm{~h}$ with blocking solution $(0.01 \%$ Tween $20,1.5 \%$ BSA and $1 \mathrm{x}$ PBS) at RT, then incubated for $1 \mathrm{~h}$ with primary antibody monoclonal anti-GP64 AcV1 $\left({ }^{34,35}\right)$ which recognizes a GP64 conformational epitope) in blocking solution (1:50). Following incubation with the secondary antibody (anti-mouse IgG conjugated with colloidal gold particles of $10 \mathrm{nM}-$ Sigma Immuno Chemicals) (1:20). Samples were washed twice in 1x PBS and once in distilled water and analyzed using TEM (JEOL 1011).

\section{Results}

\section{Purification and analysis of BVs and HIV-1 VLPs}

Sf9 cells were infected (m.o.i 1) with AcMNPV and vGAGHIV-1 in order to compare the expression pattern of VLPs and BVs. After $72 \mathrm{~h}$ p.i., the supernatants were collected and VLPs and BVs were purified by 
ultracentrifugation using a sucrose cushion (25\%) and then a sucrose gradient (30-60\%). Given the difference in size and shape of HIV-1 VLPs (around $100 \mathrm{~nm}$ ) and BVs (30 - $60 \mathrm{~nm}$ in diameter and $250-300 \mathrm{~nm}$ in length), it was expected the separation of the two types of particles, however only one band in the sucrose gradient was observed (Supplementary Figure S1). Different sucrose gradient concentrations were tested, but no differences were observed (data not shown).

The purified particles from the supernatant of cells infected with the AcMNPV virus were analyzed by $12 \%$ SDS-PAGE followed by, Coomassie Brilliant Blue staining. The presence and concentration (using a BSA standard curve) of the viral proteins (GP64 and VP39) were measured with the help of an infrared laser-scanning device. We analyzed the concentration of BV particles through the sucrose gradient detecting the presence of these proteins. It was observed that in approximately $1.19 \mathrm{~g} / \mathrm{ml}$ of sucrose, the signal for the GP64 and VP39 proteins were stronger. The confirmation of the GP64 and VP39 proteins presence was made by western blot using a monoclonal antibody anti-GP64 and a polyclonal antibody anti-VP39 (Figures 1A and 1B). Purified particles from this gradient region were analyzed by TEM using negative staining and the presence of $\mathrm{BVs}$ in this region was confirmed (Figure 1C). The approximate quantification of GP64 protein in this fraction was $2.3 \mu \mathrm{g}$ and for the VP39 protein was $0.7 \mu \mathrm{g}$ (Figure 1D). 

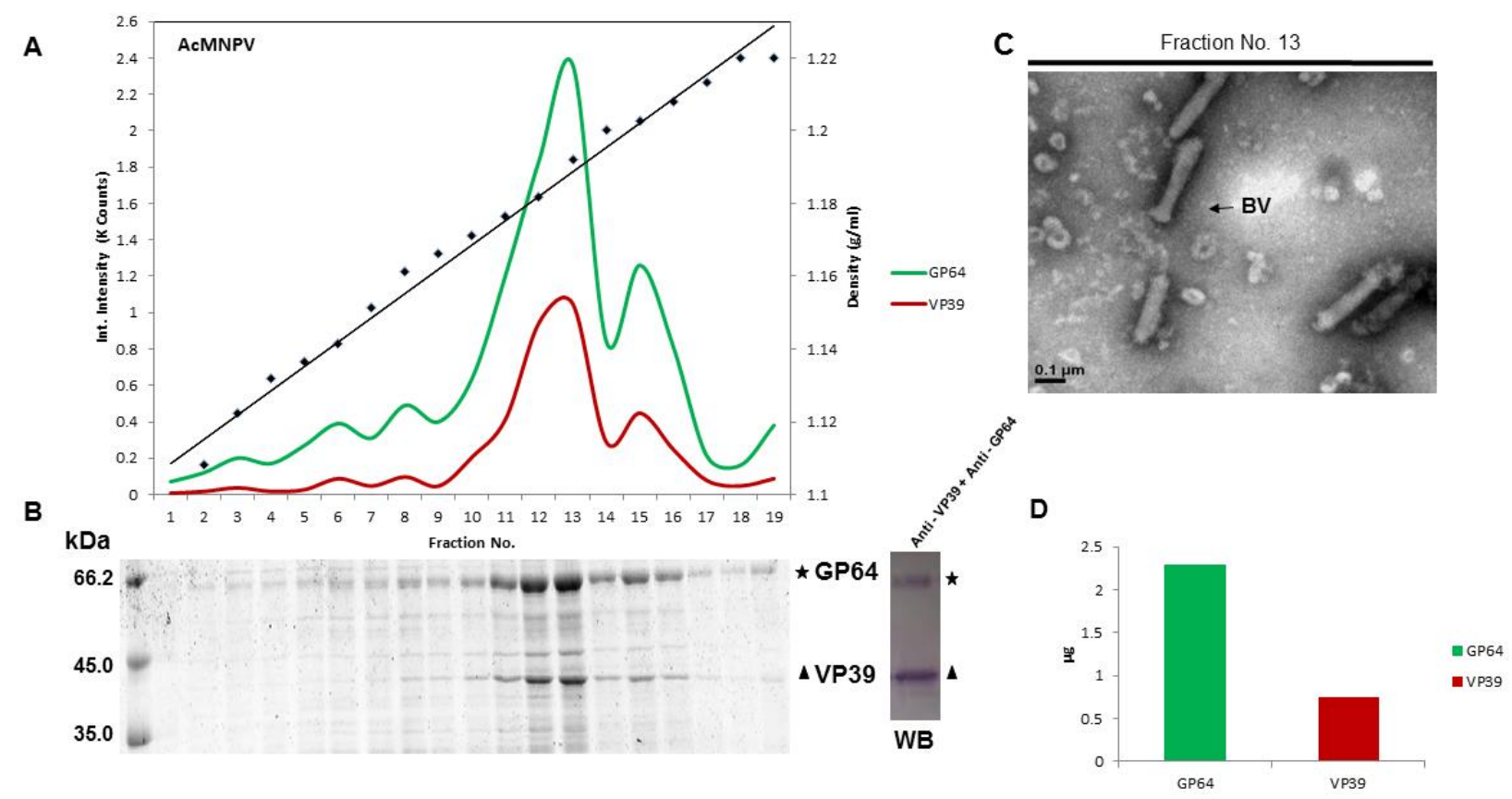

Figure 1. Purification of AcMNPV BVs particles by ultracentrifugation in sucrose gradient A) Precipitation analysis of the BV particles (by GP64 and VP39 signal) in a sucrose gradient (30$60 \%$ ). The gradient was divided in 19 fractions, starting from the top to the bottom of the tube. The presence of both proteins was detected by fluorescent signals as integrated intensities ( $\mathrm{K}$ counts) using the Odyssey Infra-red Imaging System (red line for VP39 and green line for GP64) B) Comassie blue stained $12 \%$ SDS-PAGE gel used for the analyses, and a western blot (WB) of the fraction 13 using an anti-GP64 monoclonal antibody $(\star)$ and an anti-VP39 polyclonal antibody ( $\boldsymbol{\Delta}$ ) confirming the presence of the GP64 and VP39 proteins. C) Negative staining TEM of the fraction 13 showing the BV particles (arrow) D) Quantification of the GP64 and VP39 proteins present in the fraction 13. This experiment was performed using a BSA standard curve.

The supernatant of Sf9 cells were also infected with vGAGHIV-1 at the same conditions and ultra-centrifuged through a similar sucrose gradient as described for AcMNPV. The proteins in each fraction were separated by $12 \%$ SDS-PAGE followed by Coomassie Brilliant Blue staining. The presence of each 
protein was analyzed using the same infrared laser-scanning device. In this case, we analyzed the presence of GP64 (green line), VP39 (red line) and GAG (blue line). As expected, two different peaks were observed. VLPs were located mainly in $1.18 \mathrm{~g} / \mathrm{ml}$ of sucrose (GAG peak) and BVs in $1.20 \mathrm{~g} / \mathrm{ml}$ (GP64 and VP39 peaks) (Figure 2A). However, even in the fraction showing the highest signal for GAG (fraction 11), the presence of baculovirus proteins was still very significant. Although the highest amount of GP64 and VP39 was detected in fraction 14, a very strong signal for GAG is seen in the same fraction. The presence of GP64, VP39 and GAG proteins was confirmed by western blot analysis using a monoclonal antibody for GP64 and GAG, and a polyclonal antibody for VP39 (Figure 2B). We choose the purified particles in the fraction 11 to perform a TEM analysis. As expected, VLPs particles were detected, but BVs particles were also present in the sample (Figure $2 \mathrm{C}$ ). The approximate quantification of the GAG $(1,6 \mu \mathrm{g})$, GP64 $(0,6 \mu \mathrm{g})$ and VP39 $(0,3 \mu \mathrm{g})$ proteins, in this fraction, is shown in Figure $2 \mathrm{D}$. Differently than we thought, this result showed that is not possible to separate VLPs from BVs using this method. 
A
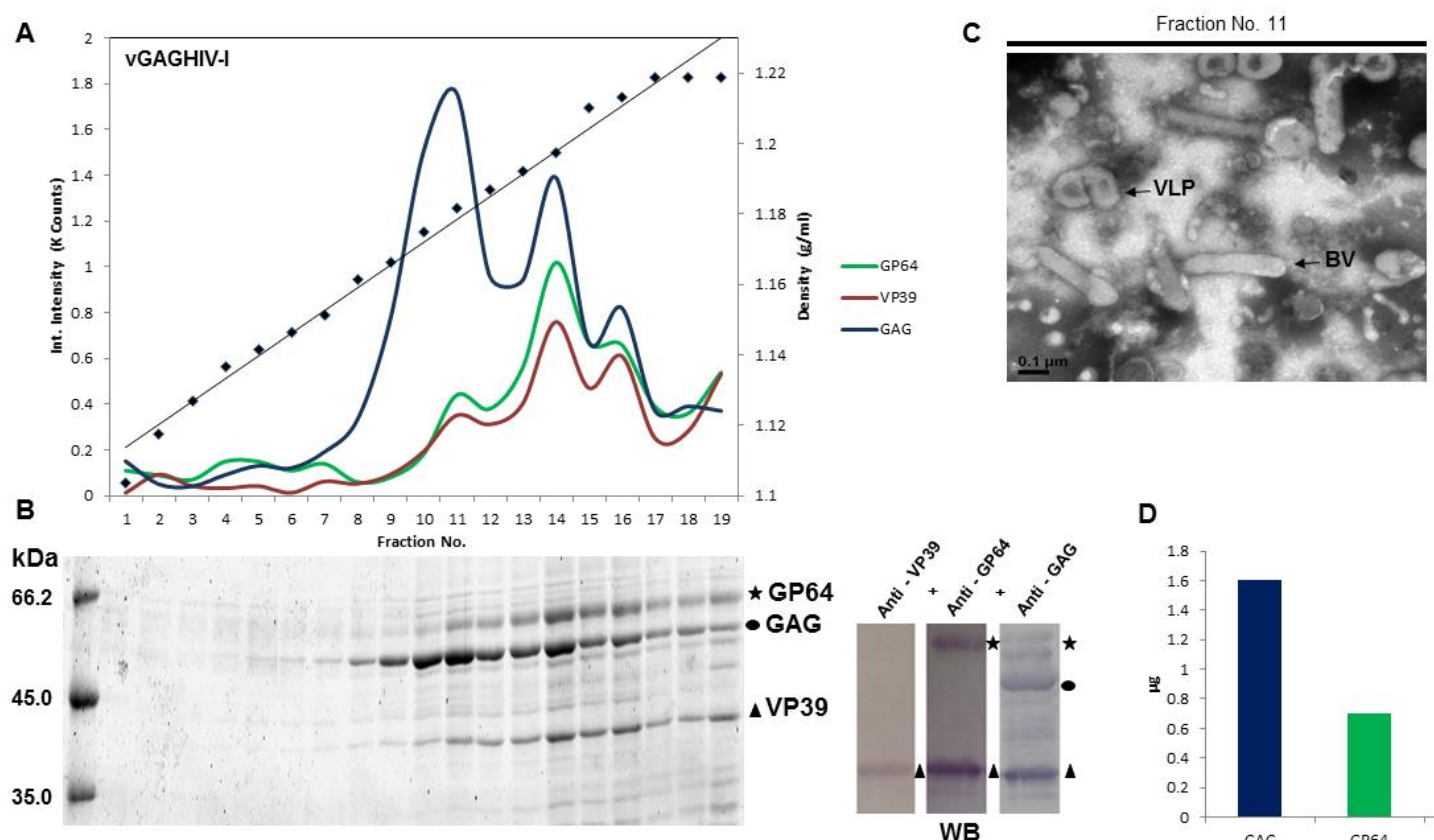

WB

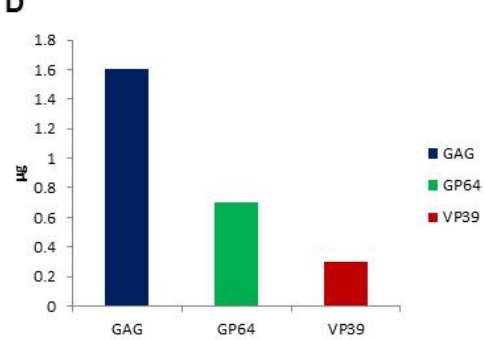

Figure 2. Purification of AcMNPV BVs and HIV-1 VLPs particles by ultracentrifugation in sucrose gradient. A) Precipitation analysis of BV and VLPs particles in a sucrose gradient (30-60\%). The gradient was divided in 19 fractions, starting from the top to the bottom. The presence of both proteins was detected by fluorescent signals as integrated intensities ( $\mathrm{K}$ counts) using the Odyssey Infra-red Imaging System (green line for GP64, red line for VP39 and blue line for GAG) B) Comassie blue stained 12\% SDS-PAGE gel used in the analyses, and a WB of the fraction 11 using three antibodies, an anti-GP64 monoclonal antibody ( $\left.{ }^{\star}\right)$, an anti-GAG monoclonal antibody $(\bullet)$ and an anti-VP39 polyclonal antibody ( $\mathbf{\Delta})$, confirming the presence of the GP64, GAG and VP39 proteins. C) Negative staining of fraction 11 sample showing the BV and VLPs particles in the same sample (arrows) D) Quantification of the GP64, VP39 and GAG proteins present in fraction 11. This experiment was performed using a BSA standard curve. 


\section{Production of GP64 free VLPs}

Based on the impossibility of VLPs and BVs separation in the same gradient, a GP64 null recombinant baculovirus expressing GAG was constructed (vGAGHIV-1 GP64 null). Known that GP64 is an essential baculovirus protein, required for binding and budding of $\mathrm{BV}$ particles, we expected that this recombinant baculovirus would not produce BV particles after infection of insect cells but would produce VLPs. To produce and propagate this recombinant virus in cell culture, we used Sf9Op1D cells. These cells express the GP64 protein from another baculovirus (OpMNPV) constitutively $\left({ }^{27}\right)$. Before using these cells, a fusion assay using different $\mathrm{pHs}$ (6.2 and 5.1) was performed in order to show that the Sf9Op1D cells were expressing GP64 correctly (Supplementary Figure S2). After virus propagation in Sf9Op1D cells, Sf9 cells were infected with vGAGHIV-1 GP64 null (m.o.i. 1), and $72 \mathrm{~h}$ p.i., cells were collected by centrifugation and the proteins in the cell extract separated by SDS-PAGE. Then, a western blot was performed, testing the cell extract for the presence of GP64, VP39 and GAG using specific antibodies. The experiment showed that no GP64 protein could be detected in cells infected with vGP64-GAGHIV-1, confirming the absence of GP64 protein in cells infected with this recombinant virus (Figure 3). 


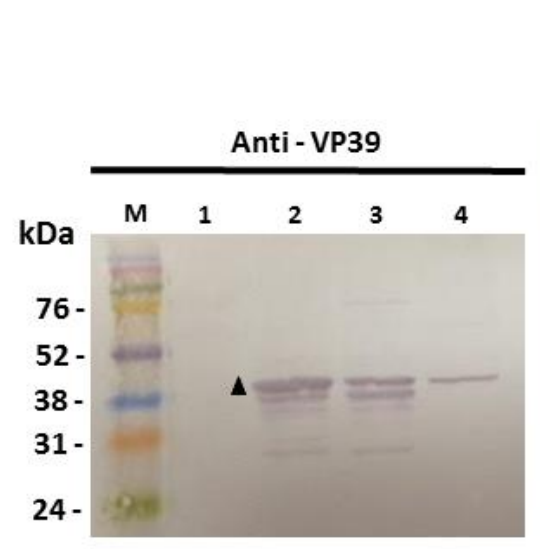

Anti - VP39 + Anti - GP64

$\begin{array}{lllll}M & 1 & 2 & 3 & 4\end{array}$

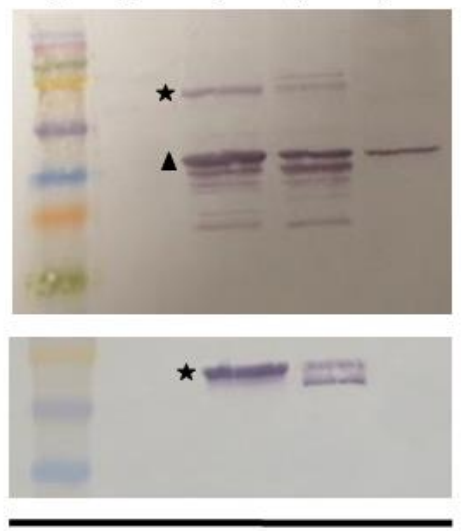

Anti - GP64
Anti - VP39 + Anti - GP64 + Anti - GAG

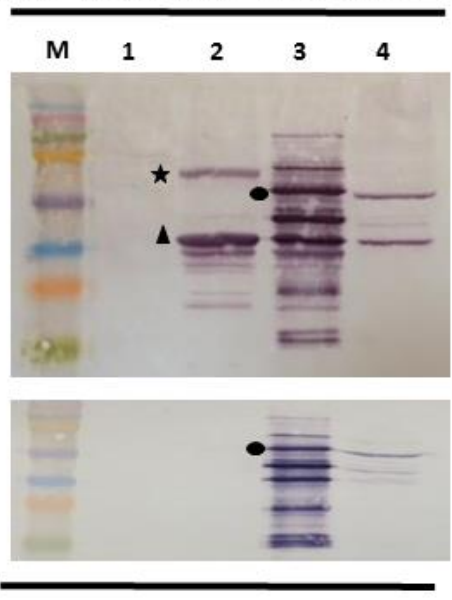

Anti-GAG

Figure 3. GP64 detection in insect cells infected with AcMNPV, vGAGHIV-1 and vGAGHIV-1 GP64 null. Sf9 cells were infected (m.o.i. 1) with the wild type AcMNPV (2), vGAGHIV-1 (3) and vGAGHIV-1 GP64 null (4) recombinant baculoviruses. Mock infected cells were used as a negative control - Mock (1). At $72 \mathrm{~h}$ p.i. cells were collected by centrifugation and the proteins separated by SDS-PAGE and transferred to nitrocellulose membrane for detection of VP39 ( $\mathbf{\Delta})$, GP64 ( $\left.{ }^{\star}\right)$ and GAG $(\bullet)$ proteins. The membrane was first incubated with a polyclonal anti-VP39, followed by incubation with a monoclonal anti-GP64 and with monoclonal anti-GAG. The GAG antibody is directed against the Gag Pr55 precursor, but, after proteolytic cleavage, different bands can be seen (p55, p47, p41 and CAp24). Membranes with the same samples were individually incubated with the same antibodies as an experimental control. $\mathrm{M}$ represents the molecular mass marker (Amersham ECL Full-Range Rainbow Molecular Weight Markers, RPN800E). 


\section{Production and characterization of GP64 free HIV-1 VLPs}

The presence or absence of the baculovirus envelope protein (GP64) on the membrane of VLPs budded from insect cells was analyzed. Sf9 cells were infected (m.o.i. 1) with the vGAGHIV-1 and vGAGHIV-1 GP64 null and at $72 \mathrm{~h}$ p.i. infected cells were prepared for immunogold labelling and TEM. The GP64 protein was easily seen on the surface of VLPs budding from Sf9 cells infected with vGAGHIV-1 (Figure $4 \mathrm{~A}$ and C). However, VLPs budding from Sf9 cells infected with vGAGHIV-1 GP64 null were GP64 free (Figure 4 B and D). VLPs produced by vGAGHIV-1 and vGAGHIV-1 GP64 null infected insect cells were purified by ultra-centrifugation and analyzed by negative staining (Figures $4 \mathrm{E}$ and F). The purified particles confirmed the production of VLPs free of GP64 from insect cells infected with vGAGHIV-1 GP64 null. 

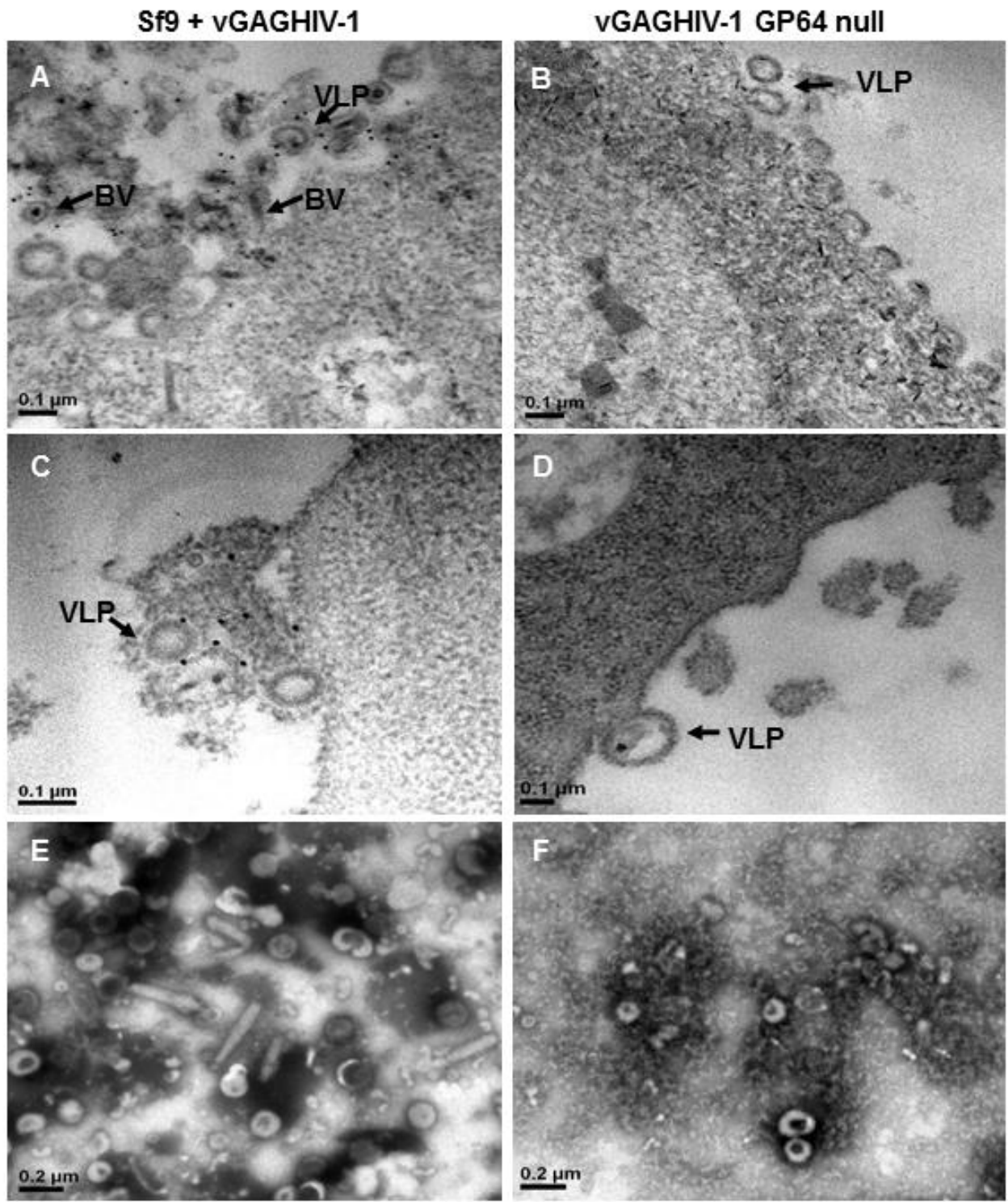

Figure 4. Electron microscopy analysis of HIV-1 VLPs produced in insect cells. Sf9 cells infected (m.o.i 1) with vGAGHIV-1 and vGAGHIV-1 GP64 null were harvested at $72 \mathrm{~h}$ p.i. and prepared for TEM Immunogold labelling (A,B,C and D) using a monoclonal antibody against GP64 (AcV1) following incubation with an anti-mouse IgG conjugated with $10 \mathrm{~nm}$ gold particles. Supernatant of the infected cells were also used for BV and VLPs purification by ultracentrifugation. (E) Negative staining of purified BV and VLP particles from vGAGHIV-1 infected Sf9 cells and (F) VLP particles from vGAGHIV-1 GP64 null infected Sf9 cells. 


\section{Discussion}

The use of VLP technology as a tool for production of recombinant vaccines or diagnostic kits is a safe, effective and a cheaper alternative, especially when they are produced using BEVS $\left({ }^{36,37}\right)$. For vaccine purposes, VLPs have to be specific and not able to induce cross-reactivity immune responses against host proteins $\left({ }^{38}\right)$. Baculovirus do not replicate in mammalian cells and the lepidopteran cells are not susceptible to contamination by human viruses or human parasites, in addition BEVS is an eukaryotic expression system, which facilitates the expression of complex proteins that requires specific posttranslational modifications $\left({ }^{39}{ }^{40}\right)$. Due to these advantages, BEVS is a good choice for VLPs production. In the case of HIV-1 VLPs, studies showing the production and characterization of these particles using BEVS have been widely explored. Lynch et al., $2012\left({ }^{41}\right)$, produced Pr55gag VLPs particles using BEVS and tested the stability of these particles. They showed that these particles can be stored up to 12 months retaining the stability, confirming the efficiency of the expression method. Pillay et al., $2009\left({ }^{42}\right)$, optimized the HIV-1 VLPs production monitoring different conditions like ideal cell density for infection, multiplicity of infection and time of infection. Based in this guideline, we set the parameters for the production of our VLPs $\left({ }^{41,42}\right)$. However, because the potential application of these VLPs in the pharmaceutical industry, immunogenicity studies of these particles are also being largely tested $\left({ }^{43,44}\right)$. Although many studies have being done with HIV-1 VLPs, no study so far was able to separate baculovirus BVs particle from VLPs produced during the same viral infection cycle, since both 
particles are co-purified using ultracentrifugation on sucrose gradients $\left.{ }^{45,46}\right)$. Different methods have been tested trying to separate BVs and VLPs produced using insect cells, like size-exclusion chromatography and affinity chromatography, but they are inefficient for large enveloped VLPs. Although baculovirus inactivation in purified VLP samples by Triton X-100 treatment has been demonstrated, this strategy works only for small and non-enveloped VLPs. It is important to emphasize that the capsids of baculovirus particles are still present in these detergent treated samples and can be a problem for the vaccine production $\left({ }^{47,48}\right)$. Thus, the production of VLPs in insect cells using BEVS without the contamination with baculovirus particles still a big challenge.

In this work the possibility of BVs and HIV-1 VLPs separation by ultracentrifugation in sucrose gradients and the presence of GP64 protein on the surface of HIV-1 VLPs were analyzed. The GP64 baculovirus envelope protein is highly immunogenic $\left({ }^{18}\right)$ and is expressed on the surface of baculovirus infected cells. When the HIV-1 GAG VLPs bud from insect cells, they are enveloped with the host cell membrane that has large amounts of the baculovirus GP64 protein. A recent study showed that each HIV-1 VLP produced using BEVS, has approximately 1 GP64 molecule for every 3 GAG molecules $\left({ }^{19}\right)$. The presence of GP64 on VLPs has the potential to increase the transduction of mammalian cells, since this protein is responsible for the cell entry by clathrin-mediated endocytosis. Lentiviral (HIV-1) vectors pseudotyped with GP64 have an increased transduction efficiently in 293T, HOS, HeLa, MDCK, BHK, and NIH 3T3 cells $\left({ }^{49,50}\right)$. The GP64 uptake has been related as a good alternative to deliver 
VLPs inside mammalian cells. However, VLPs more similar to the wild type virus particles (without baculovirus derived proteins) are more suitable for the development of vaccines or to display heterologous proteins $\left({ }^{51}\right)$.

Since it is not possible to separated BVs form VLPs, we have constructed a gp64 null recombinant baculovirus expressing Pr55 gag precursor in order to produce VLPs without BVs contamination. The deletion of the gp64 gene decrease the amount of BVs produced in more than $95 \%\left({ }^{16}\right)$. To knockout the gp64 gene in our recombinant baculoviruses, we used the simple standardized site-specific transposition, but replacing the gp64 gene for the CAT (chloramphenicol acetyltransferase gene) ${ }^{29}$ ). since GP64 is an essential protein for baculovirus propagation, the only way to amplify a gp64 defective baculovirus is to supply the GP64 protein during the infection process. In order to do that, we used a cell line that constitutively express GP64 called Sf9Op1D, previously developed by Plonsky et al., $1999\left({ }^{27}\right)$. The Sf9Op1D cell line express the OpMNPV GP64 protein that is capable of functionally complementing a deletion of the gp64 gene in the AcMNPV genome ${ }^{(52)}$. This is a known method to produce recombinant baculoviruses containing a deletion in the gp64 locus, but is the first time that this GP64 null method is used to produce VLPs purified samples without baculovirus particles. Our gp64 null Pr55 recombinant baculovirus was able to produce VLPs without contamination with BVs, but to a lesser extent when compared to the gp64 containing virus (see Figure 4). A recent study testing short interfering (si) RNAs targeting GP64 transcripts showed a reduction of BVs production without affecting the transgene expression (GFP - Green Fluorescent 
Protein and DBP - DNA-binding protein) levels inside insect cells (Sf21) ( ${ }^{53}$ ). It is important to highlight that the siRNA technique has some limitations as the requirement of other reagents (antibodies) to validate a specific gene "knockdown", the short life of 21-23 siRNAs inside the cells, and the establishment of an insect cell line constitutively expressing the corresponding interfering RNAs.

The presence of baculovirus particles in samples is a concern due to ability of these particles in trigger specific immune responses. VLPs with pharmaceutical interests have to be free of contaminants derived from the expression vector. The sucrose gradient purification of VLPs produced using BEVS could be an important step to avoid adverse effects, but we have showed the inefficiency of this method. Here we have described a simple method to minimize this step, cutting time and costs with reagents. The production of GP64 free VLPs described in this work has the potential to be used in the development of more safe and specific vaccines without baculovirus contamination.

\section{Acknowledgments}

This work was financial supported by the Brazilian agencies Conselho Nacional de Desenvolvimento Científico e Tecnológico (CNPq) and Coordenação de Aperfeiçoamento de Pessoal de Nível Superior (CAPES) - Brazil; The authors would like to thank Dr. Volker Vogt from Cornell University who kindly provided the plasmid used to construct the recombinant viruses, as well his support with this work. 


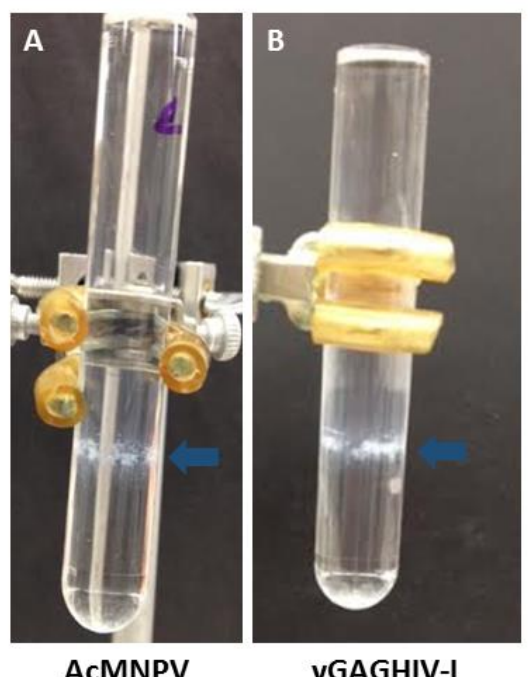

Figure S1. Photo of the sucrose gradients used to purify BVs and VLPs. A) Ultracentrifuge tube containing sucrose gradients (30-60\%) after centrifugation to purify BVs from Sf9 cells infected with AcMNPV (MOI 1) B) Ultracentrifuge tube containing sucrose gradient (30-60\%) after centrifugation to purify BVs and VLPs derived from Sf9 cells infected with vGAGHIV-1 (MOI 1). Note the formation of only a white band in the lower third of both gradients (arrows).

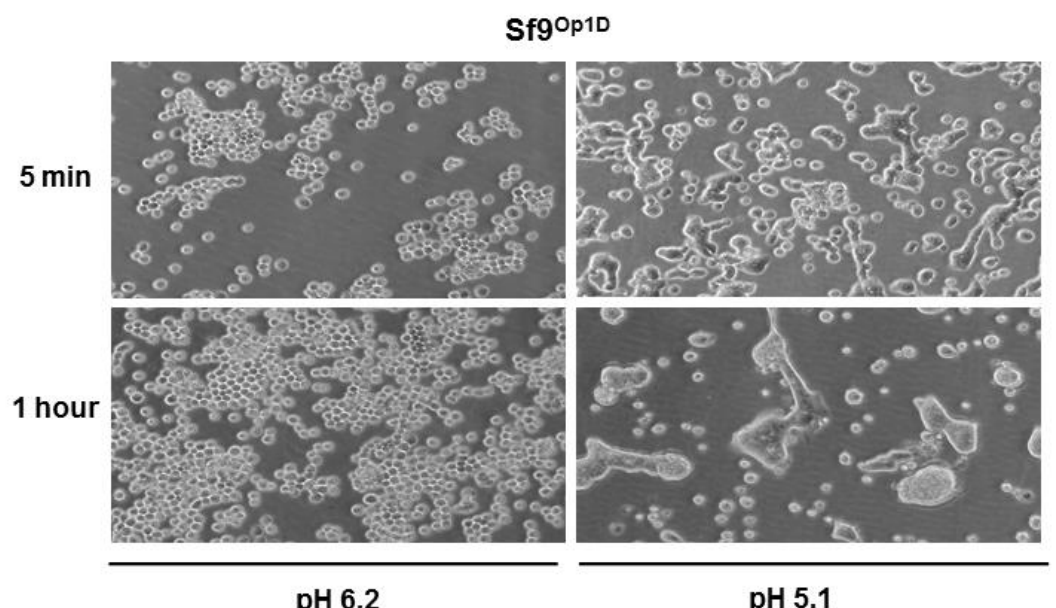

Figure S2. Sf9Op1D cells fusion assay. Sf9Op1D cells were treated with sterile PBS 1X pH 6.2 (standard $\mathrm{pH}$ of insect cell culture media) and $\mathrm{pH} 5.1$ (acidic pH that active GP64 fusion activity) for $5 \mathrm{~min}$ and $1 \mathrm{~h}$. After $5 \mathrm{~min}$, the cells starts to fuse to each other and after $1 \mathrm{~h}$ almost all the cells are fused. 


\section{References}

1 Naskalska, A. \& Pyrc, K. Virus Like Particles as Immunogens and Universal Nanocarriers. Pol J Microbiol 64, 3-13 (2015).

2 Yan, D., Wei, Y. Q., Guo, H. C. \& Sun, S. Q. The application of virus-like particles as vaccines and biological vehicles. Appl Microbiol Biotechnol 99, 10415-10432, doi:10.1007/s00253-015-7000-8 (2015).

3 Koho, T. et al. His-tagged norovirus-like particles: A versatile platform for cellular delivery and surface display. Eur J Pharm Biopharm 96, 22-31, doi:10.1016/j.ejpb.2015.07.002 (2015).

4 Kushnir, N., Streatfield, S. J. \& Yusibov, V. Virus-like particles as a highly efficient vaccine platform: diversity of targets and production systems and advances in clinical development. Vaccine 31, 58-83, doi:10.1016/j.vaccine.2012.10.083 (2012).

5 Roy, P. \& Noad, R. Virus-like particles as a vaccine delivery system: myths and facts. Hum Vaccin 4, 5-12 (2008).

6 Chackerian, B., Lenz, P., Lowy, D. R. \& Schiller, J. T. Determinants of autoantibody induction by conjugated papillomavirus virus-like particles. J Immunol 169, 6120-6126 (2002).

$7 \quad$ Kirchmeier, M. et al. Enveloped virus-like particle expression of human cytomegalovirus glycoprotein B antigen induces antibodies with potent and broad neutralizing activity. Clin Vaccine Immunol 21, 174-180, doi:10.1128/CVI.00662-13 (2014).

8 Roldao, A., Mellado, M. C., Castilho, L. R., Carrondo, M. J. \& Alves, P. M. Virus-like particles in vaccine development. Expert Rev Vaccines 9, 1149-1176, doi:10.1586/erv.10.115 (2010).

9 Liu, F., Wu, X., Li, L., Liu, Z. \& Wang, Z. Use of baculovirus expression system for generation of virus-like particles: successes and challenges. Protein Expr Purif 90, 104116, doi:10.1016/j.pep.2013.05.009 (2013).

10 Lee, H. J. et al. Efficient self-assembly and protective efficacy of infectious bursal disease virus-like particles by a recombinant baculovirus co-expressing precursor polyprotein and VP4. Virol J 12, 177, doi:10.1186/s12985-015-0403-4 (2015).

11 Ren, Z. et al. H5N1 influenza virus-like particle vaccine protects mice from heterologous virus challenge better than whole inactivated virus. Virus Res 200, 9-18, doi:10.1016/j.virusres.2015.01.007 (2015).

12 Thompson, C. M., Aucoin, M. G. \& Kamen, A. A. Production of Virus-Like Particles for Vaccination. Methods Mol Biol 1350, 299-315, doi:10.1007/978-1-4939-3043-2_14 (2016).

13 Buonaguro, L., Tagliamonte, M., Tornesello, M. L. \& Buonaguro, F. M. Developments in virus-like particle-based vaccines for infectious diseases and cancer. Expert Rev Vaccines 10, 1569-1583, doi:10.1586/erv.11.135 (2011).

14 Oomens, A. G., Monsma, S. A. \& Blissard, G. W. The baculovirus GP64 envelope fusion protein: synthesis, oligomerization, and processing. Virology 209, 592-603, doi:10.1006/viro.1995.1291 (1995).

15 Hefferon, K. L., Oomens, A. G., Monsma, S. A., Finnerty, C. M. \& Blissard, G. W. Host cell receptor binding by baculovirus GP64 and kinetics of virion entry. Virology 258, 455-468, doi:10.1006/viro.1999.9758 (1999). 
16 Oomens, A. G. \& Blissard, G. W. Requirement for GP64 to drive efficient budding of Autographa californica multicapsid nucleopolyhedrovirus. Virology 254, 297-314, doi:10.1006/viro.1998.9523 (1999).

17 Rohrmann, G. F. in Baculovirus Molecular Biology (2013).

18 Luo, W. Y. et al. Adaptive immune responses elicited by baculovirus and impacts on subsequent transgene expression in vivo. J Virol 87, 4965-4973, doi:10.1128/JVI.0351012 (2013).

19 Valley-Omar, Z., Meyers, A. E., Shephard, E. G., Williamson, A. L. \& Rybicki, E. P. Abrogation of contaminating RNA activity in HIV-1 Gag VLPs. Virol J 8, 462, doi:10.1186/1743-422X-8-462 (2011).

20 Wagner, R. et al. Studies on processing, particle formation, and immunogenicity of the HIV-1 gag gene product: a possible component of a HIV vaccine. Arch Virol 127, 117-137 (1992).

21 Provitera, P., El-Maghrabi, R. \& Scarlata, S. The effect of HIV-1 Gag myristoylation on membrane binding. Biophys Chem 119, 23-32, doi:10.1016/j.bpc.2005.08.008 (2006).

22 Morikawa, Y. et al. Complete inhibition of human immunodeficiency virus Gag myristoylation is necessary for inhibition of particle budding. J Biol Chem 271, 2868-2873 (1996).

23 Jouvenet, N., Bieniasz, P. D. \& Simon, S. M. Imaging the biogenesis of individual HIV-1 virions in live cells. Nature 454, 236-240, doi:10.1038/nature06998 (2008).

24 Gheysen, D. et al. Assembly and release of HIV-1 precursor Pr55gag virus-like particles from recombinant baculovirus-infected insect cells. Cell 59, 103-112 (1989).

25 Margine, I., Martinez-Gil, L., Chou, Y. Y. \& Krammer, F. Residual baculovirus in insect cellderived influenza virus-like particle preparations enhances immunogenicity. PLoS One 7, e51559, doi:10.1371/journal.pone.0051559 (2012).

26 Vaughn, J. L., Goodwin, R. H., Tompkins, G. J. \& McCawley, P. The establishment of two cell lines from the insect Spodoptera frugiperda (Lepidoptera; Noctuidae). In Vitro 13, 213-217 (1977).

27 Plonsky, I., Cho, M. S., Oomens, A. G., Blissard, G. \& Zimmerberg, J. An analysis of the role of the target membrane on the Gp64-induced fusion pore. Virology 253, 65-76, doi:10.1006/viro.1998.9493 (1999).

28 Hopkins, R. \& Esposito, D. A rapid method for titrating baculovirus stocks using the Sf-9 Easy Titer cell line. Biotechniques 47, 785-788, doi:10.2144/000113238 (2009).

29 Luckow, V. A., Lee, S. C., Barry, G. F. \& Olins, P. O. Efficient generation of infectious recombinant baculoviruses by site-specific transposon-mediated insertion of foreign genes into a baculovirus genome propagated in Escherichia coli. J Virol 67, 4566-4579 (1993).

30 Smith, G. E. \& Summers, M. D. Restriction Maps of Five Autographa californica MNPV Variants, Trichoplusia ni MNPV, and Galleria mellonella MNPV DNAs with Endonucleases Smal, Kpnl, BamHI, Sacl, Xhol, and EcoRI. J Virol 30, 828-838 (1979).

31 Reed, L. J. \& Muench, H. A simple method of estimating fifty percent endpoints. The American Journal of Tropical Medicine and Hygiene 27, 493-497 (1938).

32 Laemmli, U. K. Cleavage of structural proteins during the assembly of the head of bacteriophage T4. Nature 227, 680-685 (1970).

33 Brenner, S. \& Horne, R. W. A negative staining method for high resolution electron microscopy of viruses. Biochim Biophys Acta 34, 103-110 (1959). 
34 Zhou, J. \& Blissard, G. W. Mapping the conformational epitope of a neutralizing antibody (AcV1) directed against the AcMNPV GP64 protein. Virology 352, 427-437, doi:10.1016/j.virol.2006.04.041 (2006).

35 Hohmann, A. W. \& Faulkner, P. Monoclonal antibodies to baculovirus structural proteins: determination of specificities by Western blot analysis. Virology 125, 432-444 (1983).

36 van Oers, M. M. Vaccines for viral and parasitic diseases produced with baculovirus vectors. Adv Virus Res 68, 193-253, doi:10.1016/\$0065-3527(06)68006-8 (2006).

37 Metz, S. W. \& Pijlman, G. P. Arbovirus vaccines; opportunities for the baculovirus-insect cell expression system. J Invertebr Pathol 107 Suppl, S16-30, doi:10.1016/j.jip.2011.05.002 (2011).

38 Grgacic, E. V. \& Anderson, D. A. Virus-like particles: passport to immune recognition. Methods 40, 60-65, doi:10.1016/j.ymeth.2006.07.018 (2006).

39 Kost, T. A., Condreay, J. P. \& Jarvis, D. L. Baculovirus as versatile vectors for protein expression in insect and mammalian cells. Nat Biotechnol 23, 567-575, doi:10.1038/nbt1095 (2005).

40 Emery, V. C. Baculovirus expression vectors : choice of expression vector. Methods Mol Biol 8, 287-307, doi:10.1385/0-89603-191-8:287 (1992).

41 Lynch, A., Meyers, A. E., Williamson, A. L. \& Rybicki, E. P. Stability studies of HIV-1 Pr55gag virus-like particles made in insect cells after storage in various formulation media. Virol J 9, 210, doi:10.1186/1743-422X-9-210 (2012).

42 Pillay, S., Meyers, A., Williamson, A. L. \& Rybicki, E. P. Optimization of chimeric HIV-1 virus-like particle production in a baculovirus-insect cell expression system. Biotechnol Prog 25, 1153-1160, doi:10.1002/btpr.187 (2009).

43 Buonaguro, L. et al. Baculovirus-derived human immunodeficiency virus type 1 virus-like particles activate dendritic cells and induce ex vivo T-cell responses. J Virol 80, 91349143, doi:10.1128/JVI.00050-06 (2006).

44 Visciano, M. L. et al. Generation of HIV-1 Virus-Like Particles expressing different HIV-1 glycoproteins. Vaccine 29, 4903-4912, doi:10.1016/j.vaccine.2011.05.005 (2011).

45 Chua, A. J. et al. A novel platform for virus-like particle-display of flaviviral envelope domain III: induction of Dengue and West Nile virus neutralizing antibodies. Virol J 10, 129, doi:10.1186/1743-422X-10-129 (2013).

$46 \mathrm{Li}, \mathrm{W}$. et al. Self-assembly and release of peste des petits ruminants virus-like particles in an insect cell-baculovirus system and their immunogenicity in mice and goats. PLOS One 9, e104791, doi:10.1371/journal.pone.0104791 (2014).

47 Hu, Y. C., Bentley, W. E., Edwards, G. H. \& Vakharia, V. N. Chimeric infectious bursal disease virus-like particles expressed in insect cells and purified by immobilized metal affinity chromatography. Biotechnol Bioeng 63, 721-729 (1999).

48 Rueda, P. et al. Effect of different baculovirus inactivation procedures on the integrity and immunogenicity of porcine parvovirus-like particles. Vaccine 19, 726-734 (2000).

49 Kataoka, C. et al. Baculovirus GP64-mediated entry into mammalian cells. J Virol 86, 2610-2620, doi:10.1128/JVI.06704-11 (2012).

50 Kumar, M., Bradow, B. P. \& Zimmerberg, J. Large-scale production of pseudotyped lentiviral vectors using baculovirus GP64. Hum Gene Ther 14, 67-77, doi:10.1089/10430340360464723 (2003).

51 Ludwig, C. \& Wagner, R. Virus-like particles-universal molecular toolboxes. Curr Opin Biotechnol 18, 537-545, doi:10.1016/j.copbio.2007.10.013 (2007). 
52 Monsma, S. A., Oomens, A. G. \& Blissard, G. W. The GP64 envelope fusion protein is an essential baculovirus protein required for cell-to-cell transmission of infection. J Virol 70, 4607-4616 (1996).

53 Lee, H. S. et al. Small interfering (Si) RNA mediated baculovirus replication reduction without affecting target gene expression. Virus Res 199, 68-76, doi:10.1016/j.virusres.2015.01.015 (2015). 
Termos de concessão de uso de imagens e certificado de aprovação do comitê de ética 
Apr 19, 2016

This is a License Agreement between Lorena Chaves ("You") and Springer ("Springer") provided by Copyright Clearance Center ("CCC"). The license consists of your order details, the terms and conditions provided by Springer, and the payment terms and conditions.

\section{All payments must be made in full to CCC. For payment instructions, please see information listed at the bottom of this form.}

License Number

License date

Licensed content publisher

Licensed content publication

Licensed content title

Licensed content author

Licensed content date

Volume number

Issue number

Type of Use

Portion

Number of figures/tables

/illustrations

Author of this Springer

article

Order reference number

Original figure numbers

Title of your thesis /

dissertation

Expected completion date

Estimated size(pages)

Total

Terms and Conditions
3852521285868

Apr 19, 2016

Springer

Archives of Virology

On the classification and nomenclature of baculoviruses: A proposal for revision

J. A. Jehle

Jan 1, 2006

151

7

Thesis/Dissertation

Figures/tables/illustrations

1

No

None

Fig. 1. Neighbour-joining tree of the amino acid alignment of 29 baculovirus core genes of 29 sequenced baculovirus genomes

Uso de baculovírus como ferrramenta para produção de antígenos vacinais e "virus like particles" (VLPs)

Jun 2016

150

0.00 USD

Introduction

The publisher for this copyrighted material is Springer. By clicking "accept" in connection with completing this licensing transaction, you agree that the following terms and conditions apply to this transaction (along with the Billing and Payment terms and conditions established by Copyright Clearance Center, Inc. ("CCC"), at the time that you opened your Rightslink account and that are available at any time at http://myaccount.copyright.com). 
Limited License

With reference to your request to reuse material on which Springer controls the copyright, permission is granted for the use indicated in your enquiry under the following conditions: - Licenses are for one-time use only with a maximum distribution equal to the number stated in your request.

- Springer material represents original material which does not carry references to other sources. If the material in question appears with a credit to another source, this permission is not valid and authorization has to be obtained from the original copyright holder.

- This permission

- is non-exclusive

- is only valid if no personal rights, trademarks, or competitive products are infringed.

- explicitly excludes the right for derivatives.

- Springer does not supply original artwork or content.

- According to the format which you have selected, the following conditions apply accordingly:

- Print and Electronic: This License include use in electronic form provided it is password protected, on intranet, or CD-Rom/DVD or E-book/E-journal. It may not be republished in electronic open access.

- Print: This License excludes use in electronic form.

- Electronic: This License only pertains to use in electronic form provided it is password protected, on intranet, or CD-Rom/DVD or E-book/E-journal. It may not be republished in electronic open access.

For any electronic use not mentioned, please contact Springer at permissions.springer@spiglobal.com.

- Although Springer controls the copyright to the material and is entitled to negotiate on rights, this license is only valid subject to courtesy information to the author (address is given in the article/chapter).

- If you are an STM Signatory or your work will be published by an STM Signatory and you are requesting to reuse figures/tables/illustrations or single text extracts, permission is granted according to STM Permissions Guidelines: http://www.stm-assoc.org/permissionsguidelines/

For any electronic use not mentioned in the Guidelines, please contact Springer at permissions.springer@spi-global.com. If you request to reuse more content than stipulated in the STM Permissions Guidelines, you will be charged a permission fee for the excess content.

Permission is valid upon payment of the fee as indicated in the licensing process. If permission is granted free of charge on this occasion, that does not prejudice any rights we might have to charge for reproduction of our copyrighted material in the future.

-If your request is for reuse in a Thesis, permission is granted free of charge under the following conditions:

This license is valid for one-time use only for the purpose of defending your thesis and with a maximum of 100 extra copies in paper. If the thesis is going to be published, permission needs to be reobtained.

- includes use in an electronic form, provided it is an author-created version of the thesis on his/her own website and his/her university's repository, including UMI (according to the definition on the Sherpa website: http://www.sherpa.ac.uk/romeo/);

- is subject to courtesy information to the co-author or corresponding author. 
Geographic Rights: Scope

Licenses may be exercised anywhere in the world.

Altering/Modifying Material: Not Permitted

Figures, tables, and illustrations may be altered minimally to serve your work. You may not alter or modify text in any manner. Abbreviations, additions, deletions and/or any other alterations shall be made only with prior written authorization of the author(s).

Reservation of Rights

Springer reserves all rights not specifically granted in the combination of (i) the license details provided by you and accepted in the course of this licensing transaction and (ii) these terms and conditions and (iii) CCC's Billing and Payment terms and conditions.

License Contingent on Payment

While you may exercise the rights licensed immediately upon issuance of the license at the end of the licensing process for the transaction, provided that you have disclosed complete and accurate details of your proposed use, no license is finally effective unless and until full payment is received from you (either by Springer or by CCC) as provided in CCC's Billing and Payment terms and conditions. If full payment is not received by the date due, then any license preliminarily granted shall be deemed automatically revoked and shall be void as if never granted. Further, in the event that you breach any of these terms and conditions or any of CCC's Billing and Payment terms and conditions, the license is automatically revoked and shall be void as if never granted. Use of materials as described in a revoked license, as well as any use of the materials beyond the scope of an unrevoked license, may constitute copyright infringement and Springer reserves the right to take any and all action to protect its copyright in the materials.

Copyright Notice: Disclaimer

You must include the following copyright and permission notice in connection with any reproduction of the licensed material:

"Springer book/journal title, chapter/article title, volume, year of publication, page, name(s) of author(s), (original copyright notice as given in the publication in which the material was originally published) "With permission of Springer"

In case of use of a graph or illustration, the caption of the graph or illustration must be included, as it is indicated in the original publication.

Warranties: None

Springer makes no representations or warranties with respect to the licensed material and adopts on its own behalf the limitations and disclaimers established by CCC on its behalf in its Billing and Payment terms and conditions for this licensing transaction.

Indemnity

You hereby indemnify and agree to hold harmless Springer and CCC, and their respective officers, directors, employees and agents, from and against any and all claims arising out of your use of the licensed material other than as specifically authorized pursuant to this license.

No Transfer of License

This license is personal to you and may not be sublicensed, assigned, or transferred by you without Springer's written permission.

No Amendment Except in Writing

This license may not be amended except in a writing signed by both parties (or, in the case of Springer, by CCC on Springer's behalf).

Objection to Contrary Terms 
Springer hereby objects to any terms contained in any purchase order, acknowledgment, check endorsement or other writing prepared by you, which terms are inconsistent with these terms and conditions or CCC's Billing and Payment terms and conditions. These terms and conditions, together with CCC's Billing and Payment terms and conditions (which are incorporated herein), comprise the entire agreement between you and Springer (and CCC) concerning this licensing transaction. In the event of any conflict between your obligations established by these terms and conditions and those established by CCC's Billing and Payment terms and conditions, these terms and conditions shall control. Jurisdiction

All disputes that may arise in connection with this present License, or the breach thereof, shall be settled exclusively by arbitration, to be held in the Federal Republic of Germany, in accordance with German law.

\section{Other conditions:}

V 12 AUG2015

Questions? customercare@copyright.com or +1-855-239-3415 (toll free in the US) or +1-978-646-2777. 


\section{ELSEVIER LICENSE \\ TERMS AND CONDITIONS}

Apr 15, 2016

This is a License Agreement between Lorena Chaves ("You") and Elsevier ("Elsevier") provided by Copyright Clearance Center ("CCC"). The license consists of your order details, the terms and conditions provided by Elsevier, and the payment terms and conditions.

\section{All payments must be made in full to CCC. For payment instructions, please see information listed at the bottom of this form.}

Supplier

Registered Company

Number

Customer name

Customer address

License number

License date

Licensed content publisher

Licensed content publication

Licensed content title

Licensed content author

Licensed content date

Licensed content volume

number

Licensed content issue

number

Number of pages

Start Page

End Page

Type of Use

Intended publisher of new work

Portion

Number of figures/tables

/illustrations

Format

Are you the author of this

Elsevier article?

Will you be translating?
Elsevier Limited

The Boulevard,Langford Lane

Kidlington,Oxford,OX5 1GB,UK

1982084

Lorena Chaves

QRSW 07 BLOCO B1 APT 106

BRASILIA, 70675-721

3850380427934

Apr 15, 2016

Elsevier

Current Opinion in Virology

Coupling of replication and assembly in flaviviruses

Swapna Apte-Sengupta,Devika Sirohi,Richard J Kuhn

December 2014

9

$\mathrm{n} / \mathrm{a}$

9

134

142

reuse in a thesis/dissertation

other

figures/tables/illustrations

1

both print and electronic

No

Yes 


$\begin{array}{ll}\begin{array}{ll}\text { Number of languages } \\ \text { Languages }\end{array} & \begin{array}{l}1 \\ \text { PORTUGUESE figure numbers }\end{array} \\ \begin{array}{l}\text { Title of your } \\ \text { Figure 1 Flavivirus polyprotein processing } \\ \text { Uso de baculovírus como ferrramenta para produção de antígenos } \\ \text { vacinais e "virus like particles" (VLPs) }\end{array} \\ \begin{array}{l}\text { Expected completion date } \\ \text { Estimated size (number of }\end{array} & 15016 \\ \text { pages) } & \text { GB } 494627212 \\ \text { Elsevier VAT number } & 0.00 \text { USD } \\ \text { Permissions price } & 0.00 \text { USD / 0.00 GBP } \\ \text { VAT/Local Sales Tax } & 0.00 \text { USD } \\ \text { Total } & \end{array}$

Terms and Conditions

\section{INTRODUCTION}

1. The publisher for this copyrighted material is Elsevier. By clicking "accept" in connection with completing this licensing transaction, you agree that the following terms and conditions apply to this transaction (along with the Billing and Payment terms and conditions established by Copyright Clearance Center, Inc. ("CCC"), at the time that you opened your Rightslink account and that are available at any time at http://myaccount.copyright.com).

\section{GENERAL TERMS}

2. Elsevier hereby grants you permission to reproduce the aforementioned material subject to the terms and conditions indicated.

3. Acknowledgement: If any part of the material to be used (for example, figures) has appeared in our publication with credit or acknowledgement to another source, permission must also be sought from that source. If such permission is not obtained then that material may not be included in your publication/copies. Suitable acknowledgement to the source must be made, either as a footnote or in a reference list at the end of your publication, as follows:

"Reprinted from Publication title, Vol /edition number, Author(s), Title of article / title of chapter, Pages No., Copyright (Year), with permission from Elsevier [OR APPLICABLE SOCIETY COPYRIGHT OWNER]." Also Lancet special credit - "Reprinted from The Lancet, Vol. number, Author(s), Title of article, Pages No., Copyright (Year), with permission from Elsevier."

4. Reproduction of this material is confined to the purpose and/or media for which permission is hereby given.

5. Altering/Modifying Material: Not Permitted. However figures and illustrations may be altered/adapted minimally to serve your work. Any other abbreviations, additions, deletions and/or any other alterations shall be made only with prior written authorization of Elsevier Ltd. (Please contact Elsevier at permissions@elsevier.com)

6. If the permission fee for the requested use of our material is waived in this instance, please be advised that your future requests for Elsevier materials may attract a fee.

7. Reservation of Rights: Publisher reserves all rights not specifically granted in the combination of (i) the license details provided by you and accepted in the course of this licensing transaction, (ii) these terms and conditions and (iii) CCC's Billing and Payment 
terms and conditions.

8. License Contingent Upon Payment: While you may exercise the rights licensed immediately upon issuance of the license at the end of the licensing process for the transaction, provided that you have disclosed complete and accurate details of your proposed use, no license is finally effective unless and until full payment is received from you (either by publisher or by CCC) as provided in CCC's Billing and Payment terms and conditions. If full payment is not received on a timely basis, then any license preliminarily granted shall be deemed automatically revoked and shall be void as if never granted. Further, in the event that you breach any of these terms and conditions or any of CCC's Billing and Payment terms and conditions, the license is automatically revoked and shall be void as if never granted. Use of materials as described in a revoked license, as well as any use of the materials beyond the scope of an unrevoked license, may constitute copyright infringement and publisher reserves the right to take any and all action to protect its copyright in the materials.

9. Warranties: Publisher makes no representations or warranties with respect to the licensed material.

10. Indemnity: You hereby indemnify and agree to hold harmless publisher and CCC, and their respective officers, directors, employees and agents, from and against any and all claims arising out of your use of the licensed material other than as specifically authorized pursuant to this license.

11. No Transfer of License: This license is personal to you and may not be sublicensed, assigned, or transferred by you to any other person without publisher's written permission. 12. No Amendment Except in Writing: This license may not be amended except in a writing signed by both parties (or, in the case of publisher, by CCC on publisher's behalf).

13. Objection to Contrary Terms: Publisher hereby objects to any terms contained in any purchase order, acknowledgment, check endorsement or other writing prepared by you, which terms are inconsistent with these terms and conditions or CCC's Billing and Payment terms and conditions. These terms and conditions, together with CCC's Billing and Payment terms and conditions (which are incorporated herein), comprise the entire agreement between you and publisher (and CCC) concerning this licensing transaction. In the event of any conflict between your obligations established by these terms and conditions and those established by CCC's Billing and Payment terms and conditions, these terms and conditions shall control.

14. Revocation: Elsevier or Copyright Clearance Center may deny the permissions described in this License at their sole discretion, for any reason or no reason, with a full refund payable to you. Notice of such denial will be made using the contact information provided by you.

Failure to receive such notice will not alter or invalidate the denial. In no event will Elsevier or Copyright Clearance Center be responsible or liable for any costs, expenses or damage incurred by you as a result of a denial of your permission request, other than a refund of the amount(s) paid by you to Elsevier and/or Copyright Clearance Center for denied permissions.

\section{LIMITED LICENSE}

The following terms and conditions apply only to specific license types:

15. Translation: This permission is granted for non-exclusive world English rights only unless your license was granted for translation rights. If you licensed translation rights you may only translate this content into the languages you requested. A professional translator must perform all translations and reproduce the content word for word preserving the 
integrity of the article.

16. Posting licensed content on any Website: The following terms and conditions apply as follows: Licensing material from an Elsevier journal: All content posted to the web site must maintain the copyright information line on the bottom of each image; A hyper-text must be included to the Homepage of the journal from which you are licensing at http://www.sciencedirect.com/science/journal/xxxxx or the Elsevier homepage for books at http://www.elsevier.com; Central Storage: This license does not include permission for a scanned version of the material to be stored in a central repository such as that provided by Heron/XanEdu.

Licensing material from an Elsevier book: A hyper-text link must be included to the Elsevier homepage at http://www.elsevier.com . All content posted to the web site must maintain the copyright information line on the bottom of each image.

Posting licensed content on Electronic reserve: In addition to the above the following clauses are applicable: The web site must be password-protected and made available only to bona fide students registered on a relevant course. This permission is granted for 1 year only. You may obtain a new license for future website posting.

17. For journal authors: the following clauses are applicable in addition to the above: Preprints:

A preprint is an author's own write-up of research results and analysis, it has not been peer-reviewed, nor has it had any other value added to it by a publisher (such as formatting, copyright, technical enhancement etc.).

Authors can share their preprints anywhere at any time. Preprints should not be added to or enhanced in any way in order to appear more like, or to substitute for, the final versions of articles however authors can update their preprints on arXiv or RePEc with their Accepted Author Manuscript (see below).

If accepted for publication, we encourage authors to link from the preprint to their formal publication via its DOI. Millions of researchers have access to the formal publications on ScienceDirect, and so links will help users to find, access, cite and use the best available version. Please note that Cell Press, The Lancet and some society-owned have different preprint policies. Information on these policies is available on the journal homepage.

Accepted Author Manuscripts: An accepted author manuscript is the manuscript of an article that has been accepted for publication and which typically includes authorincorporated changes suggested during submission, peer review and editor-author communications.

Authors can share their accepted author manuscript:

- immediately

- via their non-commercial person homepage or blog

$\circ \quad$ by updating a preprint in arXiv or RePEc with the accepted manuscript

- via their research institute or institutional repository for internal institutional uses or as part of an invitation-only research collaboration work-group

- directly by providing copies to their students or to research collaborators for their personal use

- for private scholarly sharing as part of an invitation-only work group on commercial sites with which Elsevier has an agreement

- $\quad$ after the embargo period 
- via non-commercial hosting platforms such as their institutional repository

- via commercial sites with which Elsevier has an agreement

In all cases accepted manuscripts should:

- $\quad$ link to the formal publication via its DOI

- bear a CC-BY-NC-ND license - this is easy to do

- $\quad$ if aggregated with other manuscripts, for example in a repository or other site, be shared in alignment with our hosting policy not be added to or enhanced in any way to appear more like, or to substitute for, the published journal article.

Published journal article (JPA): A published journal article (PJA) is the definitive final record of published research that appears or will appear in the journal and embodies all value-adding publishing activities including peer review co-ordination, copy-editing, formatting, (if relevant) pagination and online enrichment.

Policies for sharing publishing journal articles differ for subscription and gold open access articles:

Subscription Articles: If you are an author, please share a link to your article rather than the full-text. Millions of researchers have access to the formal publications on ScienceDirect, and so links will help your users to find, access, cite, and use the best available version. Theses and dissertations which contain embedded PJAs as part of the formal submission can be posted publicly by the awarding institution with DOI links back to the formal publications on ScienceDirect.

If you are affiliated with a library that subscribes to ScienceDirect you have additional private sharing rights for others' research accessed under that agreement. This includes use for classroom teaching and internal training at the institution (including use in course packs and courseware programs), and inclusion of the article for grant funding purposes.

Gold Open Access Articles: May be shared according to the author-selected end-user license and should contain a CrossMark logo, the end user license, and a DOI link to the formal publication on ScienceDirect.

Please refer to Elsevier's posting policy for further information.

18. For book authors the following clauses are applicable in addition to the above: Authors are permitted to place a brief summary of their work online only. You are not allowed to download and post the published electronic version of your chapter, nor may you scan the printed edition to create an electronic version. Posting to a repository: Authors are permitted to post a summary of their chapter only in their institution's repository.

19. Thesis/Dissertation: If your license is for use in a thesis/dissertation your thesis may be submitted to your institution in either print or electronic form. Should your thesis be published commercially, please reapply for permission. These requirements include permission for the Library and Archives of Canada to supply single copies, on demand, of the complete thesis and include permission for Proquest/UMI to supply single copies, on demand, of the complete thesis. Should your thesis be published commercially, please reapply for permission. Theses and dissertations which contain embedded PJAs as part of the formal submission can be posted publicly by the awarding institution with DOI links back to the formal publications on ScienceDirect.

\section{Elsevier Open Access Terms and Conditions}


You can publish open access with Elsevier in hundreds of open access journals or in nearly 2000 established subscription journals that support open access publishing. Permitted third party re-use of these open access articles is defined by the author's choice of Creative Commons user license. See our open access license policy for more information.

Terms \& Conditions applicable to all Open Access articles published with Elsevier: Any reuse of the article must not represent the author as endorsing the adaptation of the article nor should the article be modified in such a way as to damage the author's honour or reputation. If any changes have been made, such changes must be clearly indicated. The author(s) must be appropriately credited and we ask that you include the end user license and a DOI link to the formal publication on ScienceDirect.

If any part of the material to be used (for example, figures) has appeared in our publication with credit or acknowledgement to another source it is the responsibility of the user to ensure their reuse complies with the terms and conditions determined by the rights holder.

Additional Terms \& Conditions applicable to each Creative Commons user license:

CC BY: The CC-BY license allows users to copy, to create extracts, abstracts and new works from the Article, to alter and revise the Article and to make commercial use of the Article (including reuse and/or resale of the Article by commercial entities), provided the user gives appropriate credit (with a link to the formal publication through the relevant DOI), provides a link to the license, indicates if changes were made and the licensor is not represented as endorsing the use made of the work. The full details of the license are available at http://creativecommons.org/licenses/by/4.0.

CC BY NC SA: The CC BY-NC-SA license allows users to copy, to create extracts, abstracts and new works from the Article, to alter and revise the Article, provided this is not done for commercial purposes, and that the user gives appropriate credit (with a link to the formal publication through the relevant DOI), provides a link to the license, indicates if changes were made and the licensor is not represented as endorsing the use made of the work. Further, any new works must be made available on the same conditions. The full details of the license are available at http://creativecommons.org/licenses/by-nc-sa/4.0.

CC BY NC ND: The CC BY-NC-ND license allows users to copy and distribute the Article, provided this is not done for commercial purposes and further does not permit distribution of the Article if it is changed or edited in any way, and provided the user gives appropriate credit (with a link to the formal publication through the relevant DOI), provides a link to the license, and that the licensor is not represented as endorsing the use made of the work. The full details of the license are available at http://creativecommons.org/licenses/by-nc-nd/4.0. Any commercial reuse of Open Access articles published with a CC BY NC SA or CC BY NC ND license requires permission from Elsevier and will be subject to a fee.

Commercial reuse includes:

- Associating advertising with the full text of the Article

- Charging fees for document delivery or access

- Article aggregation

- Systematic distribution via e-mail lists or share buttons

Posting or linking by commercial companies for use by customers of those companies.

\section{Other Conditions:}




\section{v1.8}

Questions? customercare@copyright.com or +1-855-239-3415 (toll free in the US) or +1-978-646-2777. file://C:/Users/Lorena/Desktop/Uso de imagens/RightsLink Printable Li... 


\section{ELSEVIER LICENSE \\ TERMS AND CONDITIONS}

Apr 15, 2016

This is a License Agreement between Lorena Chaves ("You") and Elsevier ("Elsevier") provided by Copyright Clearance Center ("CCC"). The license consists of your order details, the terms and conditions provided by Elsevier, and the payment terms and conditions.

\section{All payments must be made in full to CCC. For payment instructions, please see information listed at the bottom of this form.}

Supplier

Registered Company

Number

Customer name

Customer address

License number

License date

Licensed content publisher

Licensed content publication

Licensed content title

Licensed content author

Licensed content date

Licensed content volume

number

Licensed content issue

number

Number of pages

Start Page

End Page

Type of Use

Intended publisher of new work

Portion

Number of figures/tables

/illustrations

Format

Are you the author of this

Elsevier article?

Will you be translating?
Elsevier Limited

The Boulevard,Langford Lane

Kidlington,Oxford,OX5 1GB,UK

1982084

Lorena Chaves

QRSW 07 BLOCO B1 APT 106

BRASILIA, 70675-721

3850380994173

Apr 15, 2016

Elsevier

Journal of Clinical Virology

Flaviviruses and their antigenic structure

F.X. Heinz, Karin Stiasny

December 2012

55

4

7

289

295

reuse in a thesis/dissertation

other

figures/tables/illustrations

1

both print and electronic

No

Yes 


$\begin{array}{ll}\text { Number of languages } & 1 \\ \text { Languages } & \text { PORTUGUESE } \\ \text { Original figure numbers } & \text { Fig. 1. Flavivirus structure } \\ \begin{array}{l}\text { Title of your } \\ \text { thesis/dissertation }\end{array} & \begin{array}{l}\text { Uso de baculovírus como ferrramenta para produção de antígenos } \\ \text { vacinais e "virus like particles" (VLPs) }\end{array} \\ \begin{array}{l}\text { Expected completion date } \\ \text { Jun } 2016\end{array} \\ \begin{array}{l}\text { Estimated size (number of } \\ \text { Elsevier VAT number }\end{array} & 150 \\ \text { Permissions price } & \text { GB } 494 \text { 6272 12 } \\ \text { VAT/Local Sales Tax } & 0.00 \text { USD } \\ \text { Total } & 0.00 \text { USD / } 0.00 \text { GBP }\end{array}$

Terms and Conditions

\section{INTRODUCTION}

1. The publisher for this copyrighted material is Elsevier. By clicking "accept" in connection with completing this licensing transaction, you agree that the following terms and conditions apply to this transaction (along with the Billing and Payment terms and conditions established by Copyright Clearance Center, Inc. ("CCC"), at the time that you opened your Rightslink account and that are available at any time at http://myaccount.copyright.com).

\section{GENERAL TERMS}

2. Elsevier hereby grants you permission to reproduce the aforementioned material subject to the terms and conditions indicated.

3. Acknowledgement: If any part of the material to be used (for example, figures) has appeared in our publication with credit or acknowledgement to another source, permission must also be sought from that source. If such permission is not obtained then that material may not be included in your publication/copies. Suitable acknowledgement to the source must be made, either as a footnote or in a reference list at the end of your publication, as follows:

"Reprinted from Publication title, Vol /edition number, Author(s), Title of article / title of chapter, Pages No., Copyright (Year), with permission from Elsevier [OR APPLICABLE SOCIETY COPYRIGHT OWNER]." Also Lancet special credit - "Reprinted from The Lancet, Vol. number, Author(s), Title of article, Pages No., Copyright (Year), with permission from Elsevier."

4. Reproduction of this material is confined to the purpose and/or media for which permission is hereby given.

5. Altering/Modifying Material: Not Permitted. However figures and illustrations may be altered/adapted minimally to serve your work. Any other abbreviations, additions, deletions and/or any other alterations shall be made only with prior written authorization of Elsevier Ltd. (Please contact Elsevier at permissions@elsevier.com)

6. If the permission fee for the requested use of our material is waived in this instance, please be advised that your future requests for Elsevier materials may attract a fee.

7. Reservation of Rights: Publisher reserves all rights not specifically granted in the combination of (i) the license details provided by you and accepted in the course of this licensing transaction, (ii) these terms and conditions and (iii) CCC's Billing and Payment 
terms and conditions.

8. License Contingent Upon Payment: While you may exercise the rights licensed immediately upon issuance of the license at the end of the licensing process for the transaction, provided that you have disclosed complete and accurate details of your proposed use, no license is finally effective unless and until full payment is received from you (either by publisher or by CCC) as provided in CCC's Billing and Payment terms and conditions. If full payment is not received on a timely basis, then any license preliminarily granted shall be deemed automatically revoked and shall be void as if never granted. Further, in the event that you breach any of these terms and conditions or any of CCC's Billing and Payment terms and conditions, the license is automatically revoked and shall be void as if never granted. Use of materials as described in a revoked license, as well as any use of the materials beyond the scope of an unrevoked license, may constitute copyright infringement and publisher reserves the right to take any and all action to protect its copyright in the materials.

9. Warranties: Publisher makes no representations or warranties with respect to the licensed material.

10. Indemnity: You hereby indemnify and agree to hold harmless publisher and CCC, and their respective officers, directors, employees and agents, from and against any and all claims arising out of your use of the licensed material other than as specifically authorized pursuant to this license.

11. No Transfer of License: This license is personal to you and may not be sublicensed, assigned, or transferred by you to any other person without publisher's written permission. 12. No Amendment Except in Writing: This license may not be amended except in a writing signed by both parties (or, in the case of publisher, by CCC on publisher's behalf).

13. Objection to Contrary Terms: Publisher hereby objects to any terms contained in any purchase order, acknowledgment, check endorsement or other writing prepared by you, which terms are inconsistent with these terms and conditions or CCC's Billing and Payment terms and conditions. These terms and conditions, together with CCC's Billing and Payment terms and conditions (which are incorporated herein), comprise the entire agreement between you and publisher (and CCC) concerning this licensing transaction. In the event of any conflict between your obligations established by these terms and conditions and those established by CCC's Billing and Payment terms and conditions, these terms and conditions shall control.

14. Revocation: Elsevier or Copyright Clearance Center may deny the permissions described in this License at their sole discretion, for any reason or no reason, with a full refund payable to you. Notice of such denial will be made using the contact information provided by you.

Failure to receive such notice will not alter or invalidate the denial. In no event will Elsevier or Copyright Clearance Center be responsible or liable for any costs, expenses or damage incurred by you as a result of a denial of your permission request, other than a refund of the amount(s) paid by you to Elsevier and/or Copyright Clearance Center for denied permissions.

\section{LIMITED LICENSE}

The following terms and conditions apply only to specific license types:

15. Translation: This permission is granted for non-exclusive world English rights only unless your license was granted for translation rights. If you licensed translation rights you may only translate this content into the languages you requested. A professional translator must perform all translations and reproduce the content word for word preserving the 
integrity of the article.

16. Posting licensed content on any Website: The following terms and conditions apply as follows: Licensing material from an Elsevier journal: All content posted to the web site must maintain the copyright information line on the bottom of each image; A hyper-text must be included to the Homepage of the journal from which you are licensing at http://www.sciencedirect.com/science/journal/xxxxx or the Elsevier homepage for books at http://www.elsevier.com; Central Storage: This license does not include permission for a scanned version of the material to be stored in a central repository such as that provided by Heron/XanEdu.

Licensing material from an Elsevier book: A hyper-text link must be included to the Elsevier homepage at http://www.elsevier.com . All content posted to the web site must maintain the copyright information line on the bottom of each image.

Posting licensed content on Electronic reserve: In addition to the above the following clauses are applicable: The web site must be password-protected and made available only to bona fide students registered on a relevant course. This permission is granted for 1 year only. You may obtain a new license for future website posting.

17. For journal authors: the following clauses are applicable in addition to the above: Preprints:

A preprint is an author's own write-up of research results and analysis, it has not been peer-reviewed, nor has it had any other value added to it by a publisher (such as formatting, copyright, technical enhancement etc.).

Authors can share their preprints anywhere at any time. Preprints should not be added to or enhanced in any way in order to appear more like, or to substitute for, the final versions of articles however authors can update their preprints on arXiv or RePEc with their Accepted Author Manuscript (see below).

If accepted for publication, we encourage authors to link from the preprint to their formal publication via its DOI. Millions of researchers have access to the formal publications on ScienceDirect, and so links will help users to find, access, cite and use the best available version. Please note that Cell Press, The Lancet and some society-owned have different preprint policies. Information on these policies is available on the journal homepage.

Accepted Author Manuscripts: An accepted author manuscript is the manuscript of an article that has been accepted for publication and which typically includes authorincorporated changes suggested during submission, peer review and editor-author communications.

Authors can share their accepted author manuscript:

- immediately

- via their non-commercial person homepage or blog

$\circ \quad$ by updating a preprint in arXiv or RePEc with the accepted manuscript

- via their research institute or institutional repository for internal institutional uses or as part of an invitation-only research collaboration work-group

- directly by providing copies to their students or to research collaborators for their personal use

- for private scholarly sharing as part of an invitation-only work group on commercial sites with which Elsevier has an agreement

- $\quad$ after the embargo period 
- via non-commercial hosting platforms such as their institutional repository

- via commercial sites with which Elsevier has an agreement

In all cases accepted manuscripts should:

- $\quad$ link to the formal publication via its DOI

- bear a CC-BY-NC-ND license - this is easy to do

- $\quad$ if aggregated with other manuscripts, for example in a repository or other site, be shared in alignment with our hosting policy not be added to or enhanced in any way to appear more like, or to substitute for, the published journal article.

Published journal article (JPA): A published journal article (PJA) is the definitive final record of published research that appears or will appear in the journal and embodies all value-adding publishing activities including peer review co-ordination, copy-editing, formatting, (if relevant) pagination and online enrichment.

Policies for sharing publishing journal articles differ for subscription and gold open access articles:

Subscription Articles: If you are an author, please share a link to your article rather than the full-text. Millions of researchers have access to the formal publications on ScienceDirect, and so links will help your users to find, access, cite, and use the best available version. Theses and dissertations which contain embedded PJAs as part of the formal submission can be posted publicly by the awarding institution with DOI links back to the formal publications on ScienceDirect.

If you are affiliated with a library that subscribes to ScienceDirect you have additional private sharing rights for others' research accessed under that agreement. This includes use for classroom teaching and internal training at the institution (including use in course packs and courseware programs), and inclusion of the article for grant funding purposes.

Gold Open Access Articles: May be shared according to the author-selected end-user license and should contain a CrossMark logo, the end user license, and a DOI link to the formal publication on ScienceDirect.

Please refer to Elsevier's posting policy for further information.

18. For book authors the following clauses are applicable in addition to the above: Authors are permitted to place a brief summary of their work online only. You are not allowed to download and post the published electronic version of your chapter, nor may you scan the printed edition to create an electronic version. Posting to a repository: Authors are permitted to post a summary of their chapter only in their institution's repository.

19. Thesis/Dissertation: If your license is for use in a thesis/dissertation your thesis may be submitted to your institution in either print or electronic form. Should your thesis be published commercially, please reapply for permission. These requirements include permission for the Library and Archives of Canada to supply single copies, on demand, of the complete thesis and include permission for Proquest/UMI to supply single copies, on demand, of the complete thesis. Should your thesis be published commercially, please reapply for permission. Theses and dissertations which contain embedded PJAs as part of the formal submission can be posted publicly by the awarding institution with DOI links back to the formal publications on ScienceDirect.

\section{Elsevier Open Access Terms and Conditions}


You can publish open access with Elsevier in hundreds of open access journals or in nearly 2000 established subscription journals that support open access publishing. Permitted third party re-use of these open access articles is defined by the author's choice of Creative Commons user license. See our open access license policy for more information.

Terms \& Conditions applicable to all Open Access articles published with Elsevier: Any reuse of the article must not represent the author as endorsing the adaptation of the article nor should the article be modified in such a way as to damage the author's honour or reputation. If any changes have been made, such changes must be clearly indicated. The author(s) must be appropriately credited and we ask that you include the end user license and a DOI link to the formal publication on ScienceDirect.

If any part of the material to be used (for example, figures) has appeared in our publication with credit or acknowledgement to another source it is the responsibility of the user to ensure their reuse complies with the terms and conditions determined by the rights holder.

Additional Terms \& Conditions applicable to each Creative Commons user license:

CC BY: The CC-BY license allows users to copy, to create extracts, abstracts and new works from the Article, to alter and revise the Article and to make commercial use of the Article (including reuse and/or resale of the Article by commercial entities), provided the user gives appropriate credit (with a link to the formal publication through the relevant DOI), provides a link to the license, indicates if changes were made and the licensor is not represented as endorsing the use made of the work. The full details of the license are available at http://creativecommons.org/licenses/by/4.0.

CC BY NC SA: The CC BY-NC-SA license allows users to copy, to create extracts, abstracts and new works from the Article, to alter and revise the Article, provided this is not done for commercial purposes, and that the user gives appropriate credit (with a link to the formal publication through the relevant DOI), provides a link to the license, indicates if changes were made and the licensor is not represented as endorsing the use made of the work. Further, any new works must be made available on the same conditions. The full details of the license are available at http://creativecommons.org/licenses/by-nc-sa/4.0.

CC BY NC ND: The CC BY-NC-ND license allows users to copy and distribute the Article, provided this is not done for commercial purposes and further does not permit distribution of the Article if it is changed or edited in any way, and provided the user gives appropriate credit (with a link to the formal publication through the relevant DOI), provides a link to the license, and that the licensor is not represented as endorsing the use made of the work. The full details of the license are available at http://creativecommons.org/licenses/by-nc-nd/4.0. Any commercial reuse of Open Access articles published with a CC BY NC SA or CC BY NC ND license requires permission from Elsevier and will be subject to a fee.

Commercial reuse includes:

- Associating advertising with the full text of the Article

- Charging fees for document delivery or access

- Article aggregation

- Systematic distribution via e-mail lists or share buttons

Posting or linking by commercial companies for use by customers of those companies.

\section{Other Conditions:}


file:///C:/Users/Lorena/Desktop/Uso de imagens/RightsLink Printable Li...

\begin{abstract}
+1-978-646-2777.
\end{abstract}
$5 / 272016$

\section{v1.8}

Questions? customercare@copyright.com or +1-855-239-3415 (toll free in the US) or
\end{abstract}




\section{Copyright}

Clearance

Center

Note: Copyright.com supplies permissions but not the copyrighted content itself.
1
PAYMENT
2
REVIEW
3
CONFIRMATION

\section{Step 3: Order Confirmation}

Thank you for your order! A confirmation for your order will be sent to your account email address. If you have questions about your order, you can call us at +1.855 .239 .3415 Toll Free, M-F between 3:00 AM and 6:00 PM (Eastern), or write to us at info@copyright.com. This is not an invoice.

\section{Confirmation Number: 11556805 \\ Order Date: 04/19/2016}

\section{Payment Information}

Lorena Chaves

lorenacschaves@gmail.com

+55 (61)81560462

Payment Method: n/a
If you paid by credit card, your order will be finalized and your card will be charged within 24 hours. If you choose to be invoiced, you can change or cancel your order until the invoice is generated.

\section{Order Details}

The Journal of general virology

Order detail ID: 69694011

Order License Id: 3852510844775

ISSN:

0022-1317

Publication Type: Journal

Volume:

Issue:

Start page:

Publisher:

Author/Editor:

Microbiology Society

SOCIETY FOR GENERAL

MICROBIOLOGY ; FEDERATION OF EUROPEAN MICROBIOLOGICAL SOCIETIES

\section{Permission Status: $\checkmark$ Granted}

Permission type: Republish or display content Type of use: Republish in a thesis/dissertation

Requestor type Academic institution

Format Print, Electronic

Portion image/photo

\section{Number of} images/photos requested

1

Title or numeric reference of the portion(s)

Fig. 1. Schematic representations of flavivirus particles (a), their genome organization (b) and the viral life cycle (c)

Title of the article or chapter the portion is from
N/A 
This is not an invoice.

Total order items: 1 


\title{
Confirmation Number: 11556805
}

\section{Special Rightsholder Terms \& Conditions}

The following terms \& conditions apply to the specific publication under which they are listed

The Journal of general virology

Permission type: Republish or display content

Type of use: Republish in a thesis/dissertation

\section{TERMS AND CONDITIONS}

\section{The following terms are individual to this publisher:}

None

\author{
Other Terms and Conditions:
}

\section{STANDARD TERMS AND CONDITIONS}

1. Description of Service; Defined Terms. This Republication License enables the User to obtain licenses for republication of one or more copyrighted works as described in detail on the relevant Order Confirmation (the "Work(s)"). Copyright Clearance Center, Inc. ("CCC") grants licenses through the Service on behalf of the rightsholder identified on the Order Confirmation (the "Rightsholder"). "Republication", as used herein, generally means the inclusion of a Work, in whole or in part, in a new work or works, also as described on the Order Confirmation. "User", as used herein, means the person or entity making such republication.

2. The terms set forth in the relevant Order Confirmation, and any terms set by the Rightsholder with respect to a particular Work, govern the terms of use of Works in connection with the Service. By using the Service, the person transacting for a republication license on behalf of the User represents and warrants that he/she/it (a) has been duly authorized by the User to accept, and hereby does accept, all such terms and conditions on behalf of User, and (b) shall inform User of all such terms and conditions. In the event such person is a "freelancer" or other third party independent of User and CCC, such party shall be deemed jointly a "User" for purposes of these terms and conditions. In any event, User shall be deemed to have accepted and agreed to all such terms and conditions if User republishes the Work in any fashion.

\section{Scope of License; Limitations and Obligations.}

3.1 All Works and all rights therein, including copyright rights, remain the sole and exclusive property of the Rightsholder. The license created by the exchange of an Order Confirmation (and/or any invoice) and payment by User of the full amount set forth on that document includes only those rights expressly set forth in the Order Confirmation and in these terms and conditions, and conveys no other rights in the Work(s) to User. All rights not expressly granted are hereby reserved.

3.2 General Payment Terms: You may pay by credit card or through an account with us payable at the end of the month. If you and we agree that you may establish a standing account with CCC, then the following terms apply: Remit Payment to: Copyright Clearance Center, Dept 001, P.O. Box 843006, Boston, MA 02284-3006. Payments Due: Invoices are payable upon their delivery to you (or upon our notice to you that they are available to you for downloading). After 30 days, outstanding amounts will be subject to a service charge of $1-1 / 2 \%$ per month or, if less, the maximum rate allowed by applicable law. Unless otherwise specifically set forth in the Order Confirmation or in a separate written agreement signed by CCC, invoices are due and payable on "net 30" terms. While User may exercise the rights licensed immediately upon issuance of the Order Confirmation, the license is automatically revoked and is null and void, as if it had never been issued, if complete payment for the license is not received on a timely basis either from User directly or through a payment agent, such as a credit card company.

3.3 Unless otherwise provided in the Order Confirmation, any grant of rights to User (i) is "one-time" (including the editions and product family specified in the license), (ii) is non-exclusive and non-transferable and (iii) is subject to any and all limitations and restrictions (such as, but not limited to, limitations on duration of use or circulation) included in the Order Confirmation or invoice and/or in these terms and conditions. Upon completion of the licensed use, User shall either secure a new permission for further use of the Work(s) or immediately cease any new use of the Work(s) and shall render inaccessible (such as by deleting or by removing or severing links or other locators) any further copies of the Work (except for copies printed on paper in accordance with this license and still in User's stock at the end of such period).

3.4 In the event that the material for which a republication license is sought includes third party materials (such as photographs, illustrations, graphs, inserts and similar materials) which are identified in such material as having been used by permission, User is responsible for identifying, and seeking separate licenses (under this Service or otherwise) for, any of such third party materials; without a separate license, such third party materials may not be used. 
3.5 Use of proper copyright notice for a Work is required as a condition of any license granted under the Service. Unless otherwise provided in the Order Confirmation, a proper copyright notice will read substantially as follows: "Republished with permission of [Rightsholder's name], from [Work's title, author, volume, edition number and year of copyright]; permission conveyed through Copyright Clearance Center, Inc. " Such notice must be provided in a reasonably legible font size and must be placed either immediately adjacent to the Work as used (for example, as part of a by-line or footnote but not as a separate electronic link) or in the place where substantially all other credits or notices for the new work containing the republished Work are located. Failure to include the required notice results in loss to the Rightsholder and CCC, and the User shall be liable to pay liquidated damages for each such failure equal to twice the use fee specified in the Order Confirmation, in addition to the use fee itself and any other fees and charges specified.

3.6 User may only make alterations to the Work if and as expressly set forth in the Order Confirmation. No Work may be used in any way that is defamatory, violates the rights of third parties (including such third parties' rights of copyright, privacy, publicity, or other tangible or intangible property), or is otherwise illegal, sexually explicit or obscene. In addition, User may not conjoin a Work with any other material that may result in damage to the reputation of the Rightsholder. User agrees to inform CCC if it becomes aware of any infringement of any rights in a Work and to cooperate with any reasonable request of CCC or the Rightsholder in connection therewith.

4. Indemnity. User hereby indemnifies and agrees to defend the Rightsholder and CCC, and their respective employees and directors, against all claims, liability, damages, costs and expenses, including legal fees and expenses, arising out of any use of a Work beyond the scope of the rights granted herein, or any use of a Work which has been altered in any unauthorized way by User, including claims of defamation or infringement of rights of copyright, publicity, privacy or other tangible or intangible property.

5. Limitation of Liability. UNDER NO CIRCUMSTANCES WILL CCC OR THE RIGHTSHOLDER BE LIABLE FOR ANY DIRECT, INDIRECT, CONSEQUENTIAL OR INCIDENTAL DAMAGES (INCLUDING WITHOUT LIMITATION DAMAGES FOR LOSS OF BUSINESS PROFITS OR INFORMATION, OR FOR BUSINESS INTERRUPTION) ARISING OUT OF THE USE OR INABILITY TO USE A WORK, EVEN IF ONE OF THEM HAS BEEN ADVISED OF THE POSSIBILITY OF SUCH DAMAGES. In any event, the total liability of the Rightsholder and CCC (including their respective employees and directors) shall not exceed the total amount actually paid by User for this license. User assumes full liability for the actions and omissions of its principals, employees, agents, affiliates, successors and assigns.

6. Limited Warranties. THE WORK(S) AND RIGHT(S) ARE PROVIDED "AS IS". CCC HAS THE RIGHT TO GRANT TO USER THE RIGHTS GRANTED IN THE ORDER CONFIRMATION DOCUMENT. CCC AND THE RIGHTSHOLDER DISCLAIM ALL OTHER WARRANTIES RELATING TO THE WORK(S) AND RIGHT(S), EITHER EXPRESS OR IMPLIED, INCLUDING WITHOUT LIMITATION IMPLIED WARRANTIES OF MERCHANTABILITY OR FITNESS FOR A PARTICULAR PURPOSE. ADDITIONAL RIGHTS MAY BE REQUIRED TO USE ILLUSTRATIONS, GRAPHS, PHOTOGRAPHS, ABSTRACTS, INSERTS OR OTHER PORTIONS OF THE WORK (AS OPPOSED TO THE ENTIRE WORK) IN A MANNER CONTEMPLATED BY USER; USER UNDERSTANDS AND AGREES THAT NEITHER CCC NOR THE RIGHTSHOLDER MAY HAVE SUCH ADDITIONAL RIGHTS TO GRANT.

7. Effect of Breach. Any failure by User to pay any amount when due, or any use by User of a Work beyond the scope of the license set forth in the Order Confirmation and/or these terms and conditions, shall be a material breach of the license created by the Order Confirmation and these terms and conditions. Any breach not cured within 30 days of written notice thereof shall result in immediate termination of such license without further notice. Any unauthorized (but licensable) use of a Work that is terminated immediately upon notice thereof may be liquidated by payment of the Rightsholder's ordinary license price therefor; any unauthorized (and unlicensable) use that is not terminated immediately for any reason (including, for example, because materials containing the Work cannot reasonably be recalled) will be subject to all remedies available at law or in equity, but in no event to a payment of less than three times the Rightsholder's ordinary license price for the most closely analogous licensable use plus Rightsholder's and/or CCC's costs and expenses incurred in collecting such payment.

\section{Miscellaneous.}

8.1 User acknowledges that CCC may, from time to time, make changes or additions to the Service or to these terms and conditions, and CCC reserves the right to send notice to the User by electronic mail or otherwise for the purposes of notifying User of such changes or additions; provided that any such changes or additions shall not apply to permissions already secured and paid for.

8.2 Use of User-related information collected through the Service is governed by CCC's privacy policy, available online here: http://www.copyright.com/content/cc3/en/tools/footer/privacypolicy.html.

8.3 The licensing transaction described in the Order Confirmation is personal to User. Therefore, User may not assign or transfer to any other person (whether a natural person or an organization of any kind) the license created by the Order Confirmation and these terms and conditions or any rights granted hereunder; provided, however, that User may assign such license in its entirety on written notice to CCC in the event of a transfer of all or substantially all of User's rights in the new material which includes the Work(s) licensed under this Service.

8.4 No amendment or waiver of any terms is binding unless set forth in writing and signed by the parties. The Rightsholder and CCC hereby object to any terms contained in any writing prepared by the User or its principals, employees, agents or affiliates and purporting to govern or otherwise relate to the licensing transaction described in the Order Confirmation, which terms are in any way inconsistent with any terms set forth in the Order Confirmation and/or in these terms and conditions or CCC's standard operating procedures, whether such writing is prepared prior to, simultaneously with or subsequent to the Order Confirmation, and whether such writing appears on a copy of the Order Confirmation or in a separate instrument. 
8.5 The licensing transaction described in the Order Confirmation document shall be governed by and construed under the law of the State of New York, USA, without regard to the principles thereof of conflicts of law. Any case, controversy, suit, action, or proceeding arising out of, in connection with, or related to such licensing transaction shall be brought, at CCC's sole discretion, in any federal or state court located in the County of New York, State of New York, USA, or in any federal or state court whose geographical jurisdiction covers the location of the Rightsholder set forth in the Order Confirmation. The parties expressly submit to the personal jurisdiction and venue of each such federal or state court.If you have any comments or questions about the Service or Copyright Clearance Center, please contact us at 978-750-8400 or send an e-mail to info@copyright.com.

v 1.1 


\section{Confirmation Number: 11556805}

\section{Citation Information}

Order Detail ID: 69694011

The Journal of general virology by SOCIETY FOR GENERAL MICROBIOLOGY ; FEDERATION OF EUROPEAN MICROBIOLOGICAL SOCIETIES Reproduced with permission of Microbiology Society in the format Republish in a thesis/dissertation via Copyright Clearance Center. 


\section{ELSEVIER LICENSE \\ TERMS AND CONDITIONS}

Apr 19, 2016

This is a License Agreement between Lorena Chaves ("You") and Elsevier ("Elsevier") provided by Copyright Clearance Center ("CCC"). The license consists of your order details, the terms and conditions provided by Elsevier, and the payment terms and conditions.

\section{All payments must be made in full to CCC. For payment instructions, please see information listed at the bottom of this form.}

Supplier

Registered Company

Number

Customer name

Customer address

License number

License date

Licensed content publisher

Licensed content publication

Licensed content title

Licensed content author

Licensed content date

Licensed content volume

number

Licensed content issue number

Number of pages

Start Page

End Page

Type of Use

Portion

Number of figures/tables

/illustrations

Format

Are you the author of this

Elsevier article?

Will you be translating?

Number of languages
Elsevier Limited

The Boulevard,Langford Lane

Kidlington,Oxford,OX5 1GB,UK

1982084

Lorena Chaves

QRSW 07 BLOCO B1 APT 106

BRASILIA, 70675-721

3852520936665

Apr 19, 2016

Elsevier

Virology

Structure of yellow fever virus envelope protein domain III

David E. Volk,Fiona J. May,Sai H.A. Gandham,Anjenique Anderson,Jana J. Von Lindern,David W.C. Beasley,Alan D.T. Barrett,David G. Gorenstein

10 November 2009

394

1

7

12

18

reuse in a thesis/dissertation

figures/tables/illustrations

1

both print and electronic

No

Yes

1 
Languages

Original figure numbers

Title of your

thesis/dissertation

Expected completion date

Estimated size (number of pages)

Elsevier VAT number

Permissions price

VAT/Local Sales Tax

Total

Terms and Conditions
PORTUGUESE

Fig. 2. Neutralizing epitopes on ED3 of yellow fever (YF), dengue-2 (DEN2), Japanese encephalitis (JE), tick-borne encephalitis (TBE), and West Nile (WN) viruses. Red dots identify amino acids recognized by type-specific monoclonal antibodies.

Uso de baculovírus como ferrramenta para produção de antígenos vacinais e "virus like particles" (VLPs)

Jun 2016

150

GB 494627212

0.00 USD

0.00 USD / $0.00 \mathrm{GBP}$

0.00 USD

\section{INTRODUCTION}

1. The publisher for this copyrighted material is Elsevier. By clicking "accept" in connection with completing this licensing transaction, you agree that the following terms and conditions apply to this transaction (along with the Billing and Payment terms and conditions established by Copyright Clearance Center, Inc. ("CCC"), at the time that you opened your Rightslink account and that are available at any time at http://myaccount.copyright.com).

\section{GENERAL TERMS}

2. Elsevier hereby grants you permission to reproduce the aforementioned material subject to the terms and conditions indicated.

3. Acknowledgement: If any part of the material to be used (for example, figures) has appeared in our publication with credit or acknowledgement to another source, permission must also be sought from that source. If such permission is not obtained then that material may not be included in your publication/copies. Suitable acknowledgement to the source must be made, either as a footnote or in a reference list at the end of your publication, as follows:

"Reprinted from Publication title, Vol /edition number, Author(s), Title of article / title of chapter, Pages No., Copyright (Year), with permission from Elsevier [OR APPLICABLE SOCIETY COPYRIGHT OWNER]." Also Lancet special credit - "Reprinted from The Lancet, Vol. number, Author(s), Title of article, Pages No., Copyright (Year), with permission from Elsevier."

4. Reproduction of this material is confined to the purpose and/or media for which permission is hereby given.

5. Altering/Modifying Material: Not Permitted. However figures and illustrations may be altered/adapted minimally to serve your work. Any other abbreviations, additions, deletions and/or any other alterations shall be made only with prior written authorization of Elsevier Ltd. (Please contact Elsevier at permissions@elsevier.com)

6. If the permission fee for the requested use of our material is waived in this instance, please be advised that your future requests for Elsevier materials may attract a fee.

7. Reservation of Rights: Publisher reserves all rights not specifically granted in the combination of (i) the license details provided by you and accepted in the course of this 
licensing transaction, (ii) these terms and conditions and (iii) CCC's Billing and Payment terms and conditions.

8. License Contingent Upon Payment: While you may exercise the rights licensed immediately upon issuance of the license at the end of the licensing process for the transaction, provided that you have disclosed complete and accurate details of your proposed use, no license is finally effective unless and until full payment is received from you (either by publisher or by $\mathrm{CCC}$ ) as provided in CCC's Billing and Payment terms and conditions. If full payment is not received on a timely basis, then any license preliminarily granted shall be deemed automatically revoked and shall be void as if never granted. Further, in the event that you breach any of these terms and conditions or any of CCC's Billing and Payment terms and conditions, the license is automatically revoked and shall be void as if never granted. Use of materials as described in a revoked license, as well as any use of the materials beyond the scope of an unrevoked license, may constitute copyright infringement and publisher reserves the right to take any and all action to protect its copyright in the materials.

9. Warranties: Publisher makes no representations or warranties with respect to the licensed material.

10. Indemnity: You hereby indemnify and agree to hold harmless publisher and CCC, and their respective officers, directors, employees and agents, from and against any and all claims arising out of your use of the licensed material other than as specifically authorized pursuant to this license.

11. No Transfer of License: This license is personal to you and may not be sublicensed, assigned, or transferred by you to any other person without publisher's written permission. 12. No Amendment Except in Writing: This license may not be amended except in a writing signed by both parties (or, in the case of publisher, by CCC on publisher's behalf).

13. Objection to Contrary Terms: Publisher hereby objects to any terms contained in any purchase order, acknowledgment, check endorsement or other writing prepared by you, which terms are inconsistent with these terms and conditions or CCC's Billing and Payment terms and conditions. These terms and conditions, together with CCC's Billing and Payment terms and conditions (which are incorporated herein), comprise the entire agreement between you and publisher (and CCC) concerning this licensing transaction. In the event of any conflict between your obligations established by these terms and conditions and those established by CCC's Billing and Payment terms and conditions, these terms and conditions shall control.

14. Revocation: Elsevier or Copyright Clearance Center may deny the permissions described in this License at their sole discretion, for any reason or no reason, with a full refund payable to you. Notice of such denial will be made using the contact information provided by you. Failure to receive such notice will not alter or invalidate the denial. In no event will Elsevier or Copyright Clearance Center be responsible or liable for any costs, expenses or damage incurred by you as a result of a denial of your permission request, other than a refund of the amount(s) paid by you to Elsevier and/or Copyright Clearance Center for denied permissions.

\section{LIMITED LICENSE}

The following terms and conditions apply only to specific license types:

15. Translation: This permission is granted for non-exclusive world English rights only unless your license was granted for translation rights. If you licensed translation rights you may only translate this content into the languages you requested. A professional translator 
must perform all translations and reproduce the content word for word preserving the integrity of the article.

16. Posting licensed content on any Website: The following terms and conditions apply as follows: Licensing material from an Elsevier journal: All content posted to the web site must maintain the copyright information line on the bottom of each image; A hyper-text must be included to the Homepage of the journal from which you are licensing at http://www.sciencedirect.com/science/journal/xxxxx or the Elsevier homepage for books at http://www.elsevier.com; Central Storage: This license does not include permission for a scanned version of the material to be stored in a central repository such as that provided by Heron/XanEdu.

Licensing material from an Elsevier book: A hyper-text link must be included to the Elsevier homepage at http://www.elsevier.com . All content posted to the web site must maintain the copyright information line on the bottom of each image.

Posting licensed content on Electronic reserve: In addition to the above the following clauses are applicable: The web site must be password-protected and made available only to bona fide students registered on a relevant course. This permission is granted for 1 year only. You may obtain a new license for future website posting.

17. For journal authors: the following clauses are applicable in addition to the above: Preprints:

A preprint is an author's own write-up of research results and analysis, it has not been peer-reviewed, nor has it had any other value added to it by a publisher (such as formatting, copyright, technical enhancement etc.).

Authors can share their preprints anywhere at any time. Preprints should not be added to or enhanced in any way in order to appear more like, or to substitute for, the final versions of articles however authors can update their preprints on arXiv or RePEc with their Accepted Author Manuscript (see below).

If accepted for publication, we encourage authors to link from the preprint to their formal publication via its DOI. Millions of researchers have access to the formal publications on ScienceDirect, and so links will help users to find, access, cite and use the best available version. Please note that Cell Press, The Lancet and some society-owned have different preprint policies. Information on these policies is available on the journal homepage.

Accepted Author Manuscripts: An accepted author manuscript is the manuscript of an article that has been accepted for publication and which typically includes authorincorporated changes suggested during submission, peer review and editor-author communications.

Authors can share their accepted author manuscript:

- $\quad$ immediately

○ via their non-commercial person homepage or blog

$\circ \quad$ by updating a preprint in arXiv or RePEc with the accepted manuscript

- via their research institute or institutional repository for internal institutional uses or as part of an invitation-only research collaboration work-group

- directly by providing copies to their students or to research collaborators for their personal use

- for private scholarly sharing as part of an invitation-only work group on commercial sites with which Elsevier has an agreement 
- after the embargo period

$\circ \quad$ via non-commercial hosting platforms such as their institutional repository

- via commercial sites with which Elsevier has an agreement

In all cases accepted manuscripts should:

- link to the formal publication via its DOI

- bear a CC-BY-NC-ND license - this is easy to do

- if aggregated with other manuscripts, for example in a repository or other site, be shared in alignment with our hosting policy not be added to or enhanced in any way to appear more like, or to substitute for, the published journal article.

Published journal article (JPA): A published journal article (PJA) is the definitive final record of published research that appears or will appear in the journal and embodies all value-adding publishing activities including peer review co-ordination, copy-editing, formatting, (if relevant) pagination and online enrichment.

Policies for sharing publishing journal articles differ for subscription and gold open access articles:

Subscription Articles: If you are an author, please share a link to your article rather than the full-text. Millions of researchers have access to the formal publications on ScienceDirect, and so links will help your users to find, access, cite, and use the best available version. Theses and dissertations which contain embedded PJAs as part of the formal submission can be posted publicly by the awarding institution with DOI links back to the formal publications on ScienceDirect.

If you are affiliated with a library that subscribes to ScienceDirect you have additional private sharing rights for others' research accessed under that agreement. This includes use for classroom teaching and internal training at the institution (including use in course packs and courseware programs), and inclusion of the article for grant funding purposes.

Gold Open Access Articles: May be shared according to the author-selected end-user license and should contain a CrossMark logo, the end user license, and a DOI link to the formal publication on ScienceDirect.

Please refer to Elsevier's posting policy for further information.

18. For book authors the following clauses are applicable in addition to the above: Authors are permitted to place a brief summary of their work online only. You are not allowed to download and post the published electronic version of your chapter, nor may you scan the printed edition to create an electronic version. Posting to a repository: Authors are permitted to post a summary of their chapter only in their institution's repository.

19. Thesis/Dissertation: If your license is for use in a thesis/dissertation your thesis may be submitted to your institution in either print or electronic form. Should your thesis be published commercially, please reapply for permission. These requirements include permission for the Library and Archives of Canada to supply single copies, on demand, of the complete thesis and include permission for Proquest/UMI to supply single copies, on demand, of the complete thesis. Should your thesis be published commercially, please reapply for permission. Theses and dissertations which contain embedded PJAs as part of the formal submission can be posted publicly by the awarding institution with DOI links back to the formal publications on ScienceDirect. 


\section{Elsevier Open Access Terms and Conditions}

You can publish open access with Elsevier in hundreds of open access journals or in nearly 2000 established subscription journals that support open access publishing. Permitted third party re-use of these open access articles is defined by the author's choice of Creative Commons user license. See our open access license policy for more information.

Terms \& Conditions applicable to all Open Access articles published with Elsevier: Any reuse of the article must not represent the author as endorsing the adaptation of the article nor should the article be modified in such a way as to damage the author's honour or reputation. If any changes have been made, such changes must be clearly indicated. The author(s) must be appropriately credited and we ask that you include the end user license and a DOI link to the formal publication on ScienceDirect.

If any part of the material to be used (for example, figures) has appeared in our publication with credit or acknowledgement to another source it is the responsibility of the user to ensure their reuse complies with the terms and conditions determined by the rights holder.

Additional Terms \& Conditions applicable to each Creative Commons user license:

CC BY: The CC-BY license allows users to copy, to create extracts, abstracts and new works from the Article, to alter and revise the Article and to make commercial use of the Article (including reuse and/or resale of the Article by commercial entities), provided the user gives appropriate credit (with a link to the formal publication through the relevant DOI), provides a link to the license, indicates if changes were made and the licensor is not represented as endorsing the use made of the work. The full details of the license are available at http://creativecommons.org/licenses/by/4.0.

CC BY NC SA: The CC BY-NC-SA license allows users to copy, to create extracts, abstracts and new works from the Article, to alter and revise the Article, provided this is not done for commercial purposes, and that the user gives appropriate credit (with a link to the formal publication through the relevant DOI), provides a link to the license, indicates if changes were made and the licensor is not represented as endorsing the use made of the work. Further, any new works must be made available on the same conditions. The full details of the license are available at http://creativecommons.org/licenses/by-nc-sa/4.0.

CC BY NC ND: The CC BY-NC-ND license allows users to copy and distribute the Article, provided this is not done for commercial purposes and further does not permit distribution of the Article if it is changed or edited in any way, and provided the user gives appropriate credit (with a link to the formal publication through the relevant DOI), provides a link to the license, and that the licensor is not represented as endorsing the use made of the work. The full details of the license are available at http://creativecommons.org/licenses/by-nc-nd/4.0. Any commercial reuse of Open Access articles published with a CC BY NC SA or CC BY NC ND license requires permission from Elsevier and will be subject to a fee.

Commercial reuse includes:

- Associating advertising with the full text of the Article

- Charging fees for document delivery or access

- Article aggregation

- Systematic distribution via e-mail lists or share buttons

Posting or linking by commercial companies for use by customers of those companies.

\section{Other Conditions:}


v1.8
Questions? custome
+1-978-646-2777. v1.8
Questions? custome
+1-978-646-2777.

file://C:/Users/Lorena/Desktop/Uso de imagens/RightsLink Printable Li...

\begin{abstract}
Questions? customercare@copyright.com or +1-855-239-3415 (toll free in the US) or
\end{abstract} . 


\section{Lorena Carvalho <lorenacschaves@gmail.com>}

\section{License to use images}

Professor Shouchuan Hu <editor@aimspress.com>

17 de abril de 2016 10:33

Para: Lorena Carvalho <lorenacschaves@gmail.com>

Dear Dr. Carvalho,

Many thanks for your email.

AIMS Press journals are Open Access journals.

You do not need to get the permission to use the published content. Please cite them correctly when you use them.

Kind regards,

Dr. Shouchuan Hu

Director

AIMS Press

P.O. Box 2604

Springfield, MO 65801, USA

Email: editor@aimspress.com

Phone \& fax: 417-351-3204

http://www.aimspress.com/

From: Lorena Carvalho [mailto:Iorenacschaves@gmail.com]

Sent: 2016年4月16日 3:19

To: editor@aimspress.com

Subject: License to use images

[Texto das mensagens anteriores oculto] 


\section{ELSEVIER LICENSE}

TERMS AND CONDITIONS

Apr 15, 2016

This is a License Agreement between Lorena Chaves ("You") and Elsevier ("Elsevier") provided by Copyright Clearance Center ("CCC"). The license consists of your order details, the terms and conditions provided by Elsevier, and the payment terms and conditions.

\section{All payments must be made in full to $\mathrm{CCC}$. For payment instructions, please see information listed at the bottom of this form.}

Supplier
Registered Company Number
Customer name
Customer address

Elsevier Limited

The Boulevard,Langford Lane

Kidlington,Oxford,OX5 1GB,UK

1982084

Lorena Chaves

QRSW 07 BLOCO B1 APT 106

BRASILIA, 70675-721

License number

3850370132357

License date

Apr 15, 2016

Licensed content publisher

Elsevier

Licensed content publication

Protein Expression and Purification

Licensed content title

Use of baculovirus expression system for generation of virus-like particles: Successes and challenges

Licensed content author

Fuxiao Liu,Xiaodong Wu,Lin Li,Zengshan Liu,Zhiliang Wang

Licensed content date

August 2013

Licensed content volume number

90

Licensed content issue number 2

Number of pages

Start Page

End Page

116

Type of Use

reuse in a thesis/dissertation

Portion

figures/tables/illustrations

Number of figures/tables

/illustrations

1

Format

both print and electronic

Are you the author of this

Elsevier article?

No

Will you be translating?

Yes

Number of languages 


\section{Languages}

Original figure numbers

Title of your thesis/dissertation

Expected completion date

Estimated size (number of pages)

Elsevier VAT number

Permissions price

VAT/Local Sales Tax

Total

Terms and Conditions

\section{PORTUGUESE}

figure 2

Uso de baculovírus como ferrramenta para produção de antígenos vacinais e "virus like particles" (VLPs)

Jun 2016

150

GB 494627212

0.00 USD

$0.00 \mathrm{USD} / 0.00 \mathrm{GBP}$

0.00 USD

\section{INTRODUCTION}

1. The publisher for this copyrighted material is Elsevier. By clicking "accept" in connection with completing this licensing transaction, you agree that the following terms and conditions apply to this transaction (along with the Billing and Payment terms and conditions established by Copyright Clearance Center, Inc. ("CCC"), at the time that you opened your Rightslink account and that are available at any time at http://myaccount.copyright.com).

\section{GENERAL TERMS}

2. Elsevier hereby grants you permission to reproduce the aforementioned material subject to the terms and conditions indicated.

3. Acknowledgement: If any part of the material to be used (for example, figures) has appeared in our publication with credit or acknowledgement to another source, permission must also be sought from that source. If such permission is not obtained then that material may not be included in your publication/copies. Suitable acknowledgement to the source must be made, either as a footnote or in a reference list at the end of your publication, as follows:

"Reprinted from Publication title, Vol /edition number, Author(s), Title of article / title of chapter, Pages No., Copyright (Year), with permission from Elsevier [OR APPLICABLE SOCIETY COPYRIGHT OWNER]." Also Lancet special credit - "Reprinted from The Lancet, Vol. number, Author(s), Title of article, Pages No., Copyright (Year), with permission from Elsevier."

4. Reproduction of this material is confined to the purpose and/or media for which permission is hereby given.

5. Altering/Modifying Material: Not Permitted. However figures and illustrations may be altered/adapted minimally to serve your work. Any other abbreviations, additions, deletions and/or any other alterations shall be made only with prior written authorization of Elsevier Ltd. (Please contact Elsevier at permissions@elsevier.com) 
6. If the permission fee for the requested use of our material is waived in this instance, please be advised that your future requests for Elsevier materials may attract a fee.

7. Reservation of Rights: Publisher reserves all rights not specifically granted in the combination of (i) the license details provided by you and accepted in the course of this licensing transaction, (ii) these terms and conditions and (iii) CCC's Billing and Payment terms and conditions.

8. License Contingent Upon Payment: While you may exercise the rights licensed immediately upon issuance of the license at the end of the licensing process for the transaction, provided that you have disclosed complete and accurate details of your proposed use, no license is finally effective unless and until full payment is received from you (either by publisher or by $\mathrm{CCC}$ ) as provided in CCC's Billing and Payment terms and conditions. If full payment is not received on a timely basis, then any license preliminarily granted shall be deemed automatically revoked and shall be void as if never granted. Further, in the event that you breach any of these terms and conditions or any of CCC's Billing and Payment terms and conditions, the license is automatically revoked and shall be void as if never granted. Use of materials as described in a revoked license, as well as any use of the materials beyond the scope of an unrevoked license, may constitute copyright infringement and publisher reserves the right to take any and all action to protect its copyright in the materials.

9. Warranties: Publisher makes no representations or warranties with respect to the licensed material.

10. Indemnity: You hereby indemnify and agree to hold harmless publisher and CCC, and their respective officers, directors, employees and agents, from and against any and all claims arising out of your use of the licensed material other than as specifically authorized pursuant to this license.

11. No Transfer of License: This license is personal to you and may not be sublicensed, assigned, or transferred by you to any other person without publisher's written permission.

12. No Amendment Except in Writing: This license may not be amended except in a writing signed by both parties (or, in the case of publisher, by CCC on publisher's behalf).

13. Objection to Contrary Terms: Publisher hereby objects to any terms contained in any purchase order, acknowledgment, check endorsement or other writing prepared by you, which terms are inconsistent with these terms and conditions or CCC's Billing and Payment terms and conditions. These terms and conditions, together with CCC's Billing and Payment terms and conditions (which are incorporated herein), comprise the entire agreement between you and publisher (and CCC) concerning this licensing transaction. In the event of any conflict between your obligations established by these terms and conditions and those established by CCC's Billing and Payment terms and conditions, these terms and conditions shall control.

14. Revocation: Elsevier or Copyright Clearance Center may deny the permissions described in this License at their sole discretion, for any reason or no reason, with a full refund payable to you. Notice of such denial will be made using the contact information provided by you. 
Failure to receive such notice will not alter or invalidate the denial. In no event will Elsevier or Copyright Clearance Center be responsible or liable for any costs, expenses or damage incurred by you as a result of a denial of your permission request, other than a refund of the amount(s) paid by you to Elsevier and/or Copyright Clearance Center for denied permissions.

\section{LIMITED LICENSE}

The following terms and conditions apply only to specific license types:

15. Translation: This permission is granted for non-exclusive world English rights only unless your license was granted for translation rights. If you licensed translation rights you may only translate this content into the languages you requested. A professional translator must perform all translations and reproduce the content word for word preserving the integrity of the article.

16. Posting licensed content on any Website: The following terms and conditions apply as follows: Licensing material from an Elsevier journal: All content posted to the web site must maintain the copyright information line on the bottom of each image; A hyper-text must be included to the Homepage of the journal from which you are licensing at http://www.sciencedirect.com/science/journal/xxxxx or the Elsevier homepage for books at http://www.elsevier.com; Central Storage: This license does not include permission for a scanned version of the material to be stored in a central repository such as that provided by Heron/XanEdu.

Licensing material from an Elsevier book: A hyper-text link must be included to the Elsevier homepage at http://www.elsevier.com . All content posted to the web site must maintain the copyright information line on the bottom of each image.

Posting licensed content on Electronic reserve: In addition to the above the following clauses are applicable: The web site must be password-protected and made available only to bona fide students registered on a relevant course. This permission is granted for 1 year only. You may obtain a new license for future website posting.

17. For journal authors: the following clauses are applicable in addition to the above:

\section{Preprints:}

A preprint is an author's own write-up of research results and analysis, it has not been peer-reviewed, nor has it had any other value added to it by a publisher (such as formatting, copyright, technical enhancement etc.).

Authors can share their preprints anywhere at any time. Preprints should not be added to or enhanced in any way in order to appear more like, or to substitute for, the final versions of articles however authors can update their preprints on arXiv or RePEc with their Accepted Author Manuscript (see below).

If accepted for publication, we encourage authors to link from the preprint to their formal publication via its DOI. Millions of researchers have access to the formal publications on 
ScienceDirect, and so links will help users to find, access, cite and use the best available version. Please note that Cell Press, The Lancet and some society-owned have different preprint policies. Information on these policies is available on the journal homepage.

Accepted Author Manuscripts: An accepted author manuscript is the manuscript of an article that has been accepted for publication and which typically includes authorincorporated changes suggested during submission, peer review and editor-author communications.

Authors can share their accepted author manuscript:

- immediately

○ via their non-commercial person homepage or blog

- by updating a preprint in arXiv or RePEc with the accepted manuscript

- via their research institute or institutional repository for internal institutional uses or as part of an invitation-only research collaboration work-group

- directly by providing copies to their students or to research collaborators for their personal use

$\circ \quad$ for private scholarly sharing as part of an invitation-only work group on commercial sites with which Elsevier has an agreement

- $\quad$ after the embargo period

- via non-commercial hosting platforms such as their institutional repository

○ via commercial sites with which Elsevier has an agreement

In all cases accepted manuscripts should:

- $\quad$ link to the formal publication via its DOI

- bear a CC-BY-NC-ND license - this is easy to do

- $\quad$ if aggregated with other manuscripts, for example in a repository or other site, be shared in alignment with our hosting policy not be added to or enhanced in any way to appear more like, or to substitute for, the published journal article.

Published journal article (JPA): A published journal article (PJA) is the definitive final record of published research that appears or will appear in the journal and embodies all value-adding publishing activities including peer review co-ordination, copy-editing, formatting, (if relevant) pagination and online enrichment.

Policies for sharing publishing journal articles differ for subscription and gold open access articles:

Subscription Articles: If you are an author, please share a link to your article rather than the 
full-text. Millions of researchers have access to the formal publications on ScienceDirect, and so links will help your users to find, access, cite, and use the best available version.

Theses and dissertations which contain embedded PJAs as part of the formal submission can be posted publicly by the awarding institution with DOI links back to the formal publications on ScienceDirect.

If you are affiliated with a library that subscribes to ScienceDirect you have additional private sharing rights for others' research accessed under that agreement. This includes use for classroom teaching and internal training at the institution (including use in course packs and courseware programs), and inclusion of the article for grant funding purposes.

Gold Open Access Articles: May be shared according to the author-selected end-user license and should contain a CrossMark logo, the end user license, and a DOI link to the formal publication on ScienceDirect.

Please refer to Elsevier's posting policy for further information.

18. For book authors the following clauses are applicable in addition to the above: Authors are permitted to place a brief summary of their work online only. You are not allowed to download and post the published electronic version of your chapter, nor may you scan the printed edition to create an electronic version. Posting to a repository: Authors are permitted to post a summary of their chapter only in their institution's repository.

19. Thesis/Dissertation: If your license is for use in a thesis/dissertation your thesis may be submitted to your institution in either print or electronic form. Should your thesis be published commercially, please reapply for permission. These requirements include permission for the Library and Archives of Canada to supply single copies, on demand, of the complete thesis and include permission for Proquest/UMI to supply single copies, on demand, of the complete thesis. Should your thesis be published commercially, please reapply for permission. Theses and dissertations which contain embedded PJAs as part of the formal submission can be posted publicly by the awarding institution with DOI links back to the formal publications on ScienceDirect.

\section{$\underline{\text { Elsevier Open Access Terms and Conditions }}$}

You can publish open access with Elsevier in hundreds of open access journals or in nearly 2000 established subscription journals that support open access publishing. Permitted third party re-use of these open access articles is defined by the author's choice of Creative Commons user license. See our open access license policy for more information.

\section{Terms \& Conditions applicable to all Open Access articles published with Elsevier:}

Any reuse of the article must not represent the author as endorsing the adaptation of the article nor should the article be modified in such a way as to damage the author's honour or reputation. If any changes have been made, such changes must be clearly indicated.

The author(s) must be appropriately credited and we ask that you include the end user 
license and a DOI link to the formal publication on ScienceDirect.

If any part of the material to be used (for example, figures) has appeared in our publication with credit or acknowledgement to another source it is the responsibility of the user to ensure their reuse complies with the terms and conditions determined by the rights holder.

\section{Additional Terms \& Conditions applicable to each Creative Commons user license:}

CC BY: The CC-BY license allows users to copy, to create extracts, abstracts and new works from the Article, to alter and revise the Article and to make commercial use of the Article (including reuse and/or resale of the Article by commercial entities), provided the user gives appropriate credit (with a link to the formal publication through the relevant DOI), provides a link to the license, indicates if changes were made and the licensor is not represented as endorsing the use made of the work. The full details of the license are available at http://creativecommons.org/licenses/by/4.0.

CC BY NC SA: The CC BY-NC-SA license allows users to copy, to create extracts, abstracts and new works from the Article, to alter and revise the Article, provided this is not done for commercial purposes, and that the user gives appropriate credit (with a link to the formal publication through the relevant DOI), provides a link to the license, indicates if changes were made and the licensor is not represented as endorsing the use made of the work. Further, any new works must be made available on the same conditions. The full details of the license are available at http://creativecommons.org/licenses/by-nc-sa/4.0.

CC BY NC ND: The CC BY-NC-ND license allows users to copy and distribute the Article, provided this is not done for commercial purposes and further does not permit distribution of the Article if it is changed or edited in any way, and provided the user gives appropriate credit (with a link to the formal publication through the relevant DOI), provides a link to the license, and that the licensor is not represented as endorsing the use made of the work. The full details of the license are available at http://creativecommons.org/licenses/by-nc-nd/4.0. Any commercial reuse of Open Access articles published with a CC BY NC SA or CC BY NC ND license requires permission from Elsevier and will be subject to a fee.

Commercial reuse includes:

- $\quad$ Associating advertising with the full text of the Article

- Charging fees for document delivery or access

- Article aggregation

- Systematic distribution via e-mail lists or share buttons

Posting or linking by commercial companies for use by customers of those companies.

\section{Other Conditions:}


RightsLink Printable License
\[ \begin{array}{l}\text { v1.8 } \\ \text { Questions? custo } \\ +1-978-646-2777\end{array} \]

Questions? customercare@copyright.com or +1-855-239-3415 (toll free in the US) or

RightsLink Printable License
\[ \begin{array}{l}\text { v1.8 } \\ \text { Questions? custoI } \\ +1-978-646-2777 .\end{array} \]

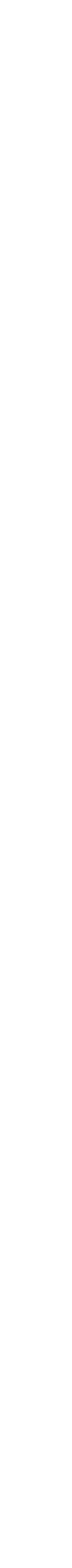




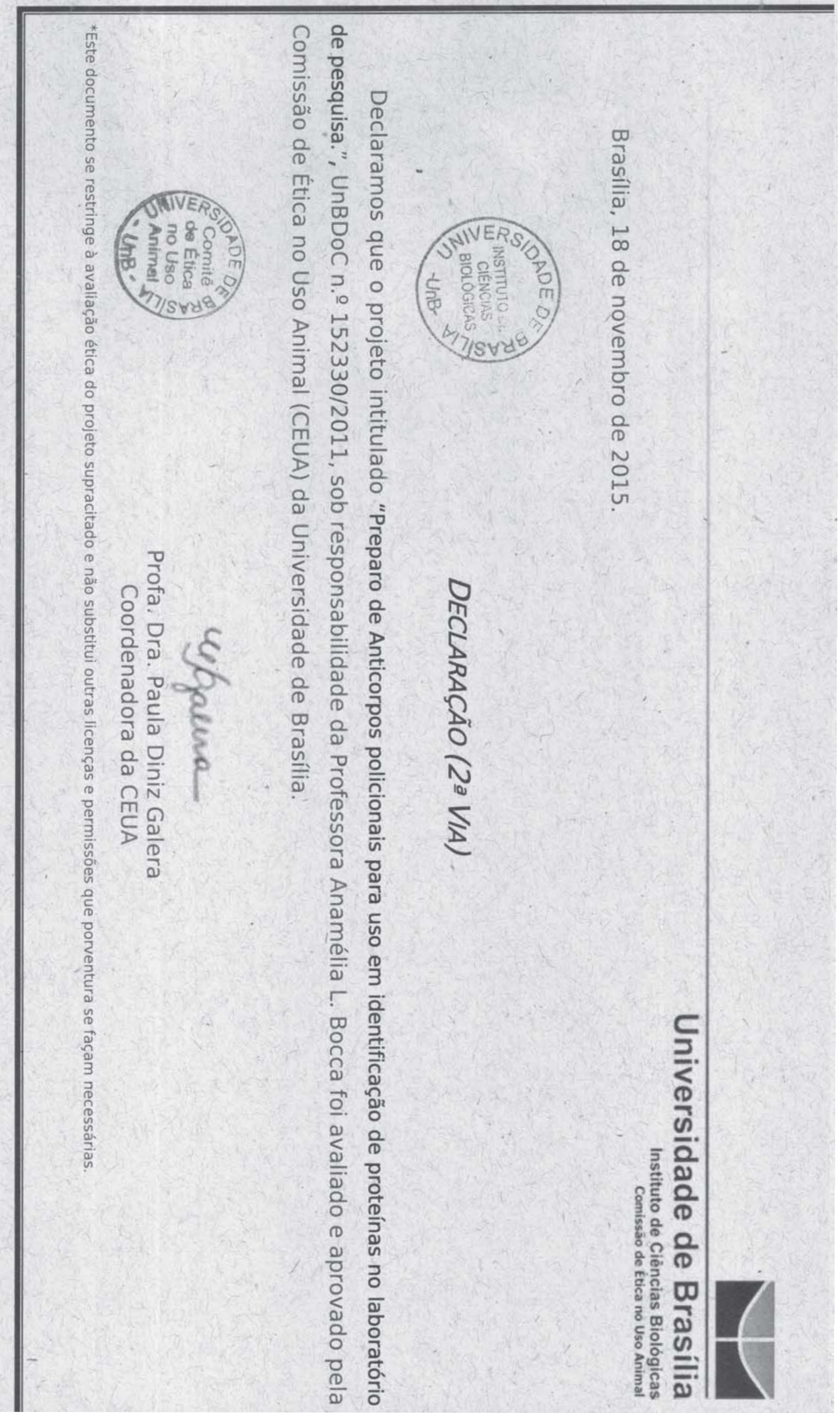

